1871

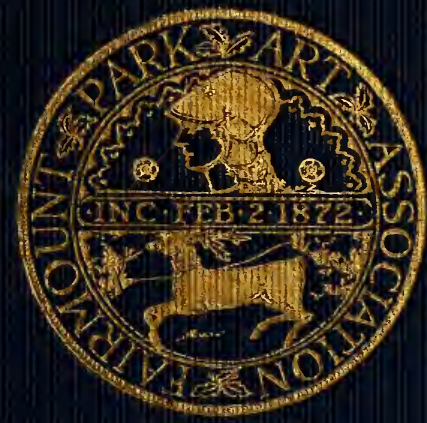

1921

PHILADEL.PHIA 


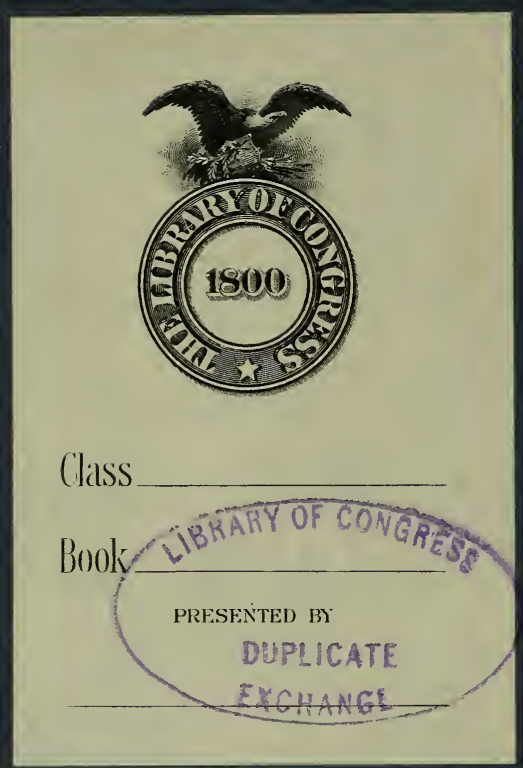




50TH ANNIVERSARY

$$
\text { of the }
$$

FAIRMOUNT PARK

ART ASSOCIATION

$$
\text { I } 87 \mathbf{I} \text { - I92 I }
$$




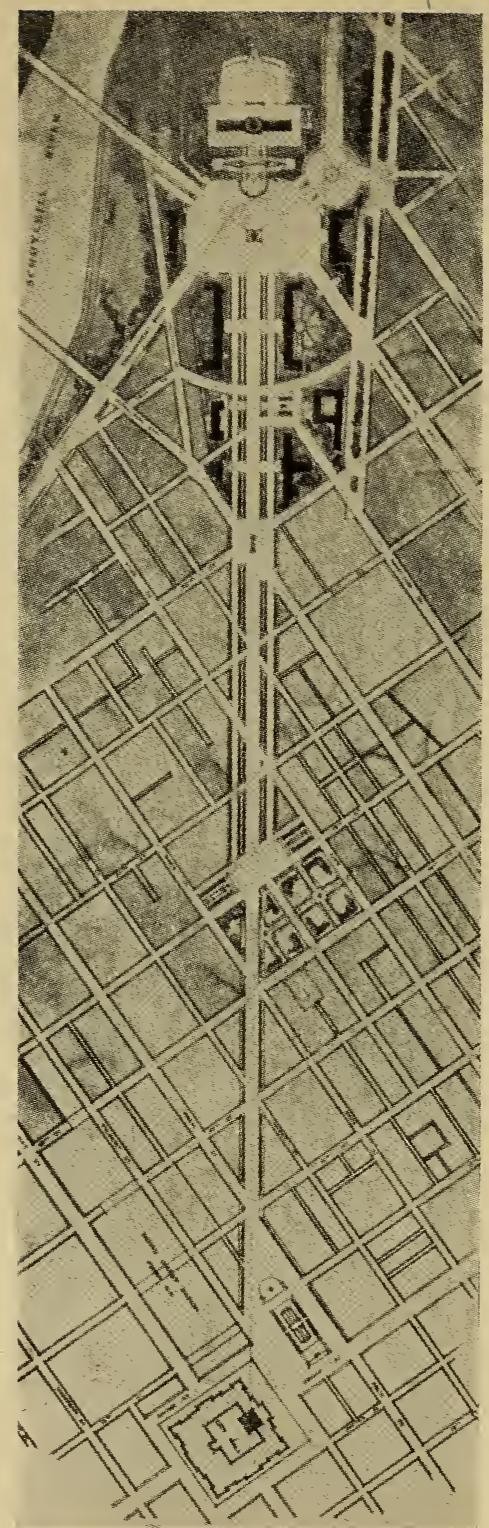

1907 PLAN OF THE FAIRMOUNT PARKWAY

Prepared under a commission from the Fairmount Park Art Association by Paul P. Cret, Horace Trumbauer and C. C. Zantzinger.

Adopted by the City of Philadelphia in 1909.

The execution of this plan is about completed. 
921 FAIRMOUNT PARK ART ASSOCIATION

An Account of its Origin and Activities from its Foundation in 1871. Issued on the Occasion of its FifTIETH Anniversary 1921

NMAANPQ LIRRARY
Relabelef

FEB \% : 9989

SMITHSONIAN INSTITUTION

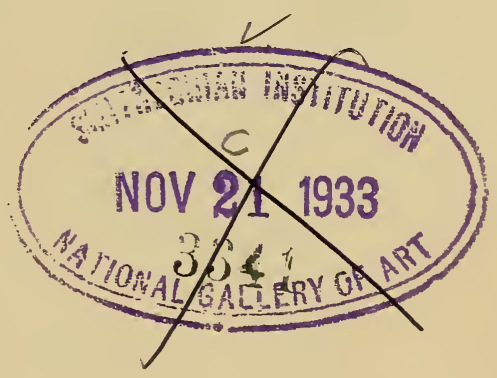

PUBLISHED BY THE A SSOCIATION

PHILADELPHIA

1922 
"The true measure of a community is the measure of the things for which it cares and that the record of such greatness of spirit and such nobleness of purpose as it possesses are embodied in the work it leaves behind: that the memory and influence of such worthiness as it ever develops, if it lives at all, is perpetuated by its art alone. So that no better service can be rendered to the community, in which we happen to live, than the promotion in every possible way of those forms of culture and the cherishing of those ideals, which find expression in art."

\section{Leslie W. Miller}

\section{Committee on Fiftieth Anniversary}

Andrew Wright Crawford, Chairman

Charles Louis Borie, Jr.

Eli Kirk Price

Charles J. Cohen, $\epsilon x$ officio

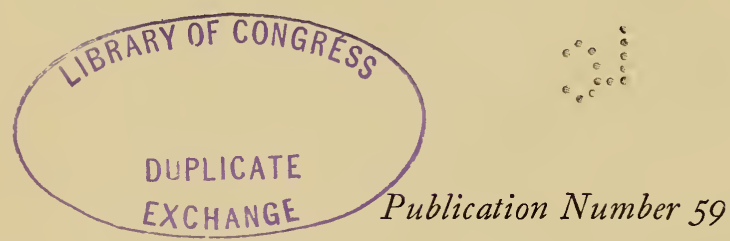

Copyrighted by

FAIRMOUNT PARK ART ASSOCIATION

1922

$$
\begin{aligned}
& \text { By Granter } \\
& \text { tan } 31.1923 \\
& \text { gen sTat }
\end{aligned}
$$




\section{OFFICERS}

1921

PRESIDENT

Charles J. Cohen

VICE-PRESIDENTS

James M. Beck Henry K. Fox

TREASURER

W. Hinckle Smith

SECRETARY

Roland L. TAYlor

320 South Broad Street

\section{BOARD OF TRUSTEES}

Term Expires in I92I

C. L. BORIE, JR.

Andrew Wright Crawford

Henry K. Fox

Albert Kelsey

ROLAND L. TAYLOR

Joseph Widener

Term Expires in 1922

James M. Beck

Charles J. Cohen

Huger Elliott
Eli Kirk Price

Edgar V. Seeler

Joseph Allison Steinmetz

Term Expires in 1923

*A. G. Hetherington

J. Franklin McFadden

John D. McIlhenny

J. Rodman Paul

W. Hinckle Smith

George S. Webster

\section{COUNSEL}

JAMES M. BECK

*Deceased. 


\section{STANDING COMMITTEES}

(The President is ex officio a member of all Committees)

I. On Works of Art

*Edward H. Coates

Paul P. Cret

*A. G. Hetherington

Albert Kelsey

Howard Longstreth

Edgar V. Seeler

Joseph Widener

2. Auditing Committee

Joseph Allison Steinmetz, Chairman John D. McIlnenny

3. On Finance, Legacies and Trusts

Henry K. Fox

W. Hinckle Smith, Chairman

John D. McIlhenny

Joseph Allison Steinmetz

Roland L. TAYLOR

\section{SPECIAL COMMITTEES}

\section{On Robert Morris Memorial}

James M. Beck

Roland L. Taylor, Chairman

Henry H. Collins

Henry K. Fox

Joseph Allison Steinmetz EFfingham B. Morris *Francis B. Reeves Levi L. Rue

2. On Ericsson Memorial

Edward T. Stotesbury, Chairman

Theophilus P. Chandler

*Edward H. Coates

John Story Jenks

Albert Kelsey

Henry M. Dechert

Samuel S. Fels

W. W. Gibis

*Robert E. Hastings

J. Bertram Lippincott

William Potter

Thomas Harris Powers

Joseph Allison Steinmetz

3. On Shakespeare Memorial Eli Kirk Price, Chairman James M. Beck

Edward Biddle

4. On Samuel Foundation

Charles L. Borie, Jr., Chairman
ELI KIRK PRICE

J. Bunford Samuel

*Deceased. 


\section{TABLE OF CONTENTS}

Address, "The Utility of Civic Beauty," at the Celebration of the Fiftieth Anniversary, by Hon. James M. Beck............ 11

History of the Association by Charles J. Cohen, President........ 31

List of Officers and Trustees........................ 75

Biographies of the Founders of the Association and Members of the

First Board of Trustees (For names and pages see Index)...... 79

List of Works of Art Contributed by the Association

Park Branch................................. 131

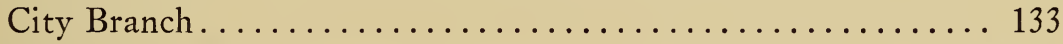

Reproduction of Works of Art................... 134-183

Biographies of the Sculptors. . . . . . . . . . . . . . 185

History of the Fairmount Parkway and Art Museum, by Andrew

Wright Crawford, George S. Webster and the late William Perrine 244

List of Addresses at the Annual Meetings............... 253

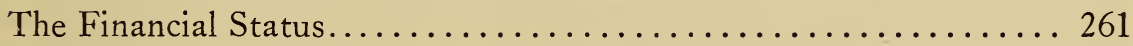

Preamble to the Original Constitution................. 262

Members.................................... 264 


\section{GELEBRATION OF THE FIFTIETH ANNIVERSARY}

The Fiftieth Anniversary of the Fairmount Park Art Association was celebrated on June 7, 1921, by a tour of Fairmount Park, an inspection of the Art Museum, then in course of construction, and a meeting in the Portico of the Water-Works. Over one hundred people met in Logan Square and were conducted in sight-seeing automobiles through the East and West Park to view the various works of Art given by or under the auspices of the Fairmount Park Art Association. The automobiles ascended Fairmount. The Association's guests were conducted over the Museum and thence proceeded to the Portico.

Mr. Charles J. Cohen, President of the Association, spoke briefly, and introduced the Honorable James M. Beck, who delivered an address on "The Utility of Civic Beauty." After the addresses supper was served on the terrace of the WaterWorks. 


\title{
THE UTILITY OF GIVIC BEAUTY
}

BY

\author{
JAMES MONTGOMERY BECK, LL.D., Litt. D.
}

MCr. President, Ladies and Gentlemen:

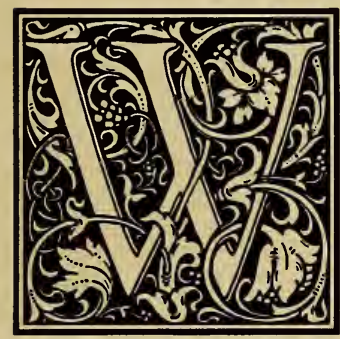

E ARE met this afternoon to celebrate no mean or unimportant event in the annals of this historic city. Fifty years ago the Fairmount Park Art Association was born and I need say no more than to quote the most gifted sculptor that America ever gave to the world, Augustus Saint-Gaudens, who once said to me that the Fairmount Park Art Association was "not only the first but was still the best of the civic movements of its class in the United States."

It is well, therefore, for us to remember gratefully those who initiated this movement a half century ago. To tell what they did-and what resulted-should be an inspiration to the present generation of Philadelphians and especially to the young men and women of Philadelphia.

In the summer of 1871 there was a young man in Philadelphia by the name of Charles $\mathrm{H}$. Howell. He was only twenty-three years of age and was only one among, let us say, 700,000 people. What could one young man do to advance the city that he so dearly loved? He thought, as Fairmount Park was at that time expanding its beautiful domain as far as the upper Wissahickon, that perhaps the greatest service he could render in his lifetime was to initiate a movement that would add the art of man to the gifts with which God had so prodigally endowed this magnificent pleasure domain. With this purpose he met in conference with another young man, who is still living in Philadelphia and whose name ought also to be gratefully remembered, Henry K. Fox.

It is well for us to recall for a moment the conditions in 1871 , upon which these two young men were obliged to base 


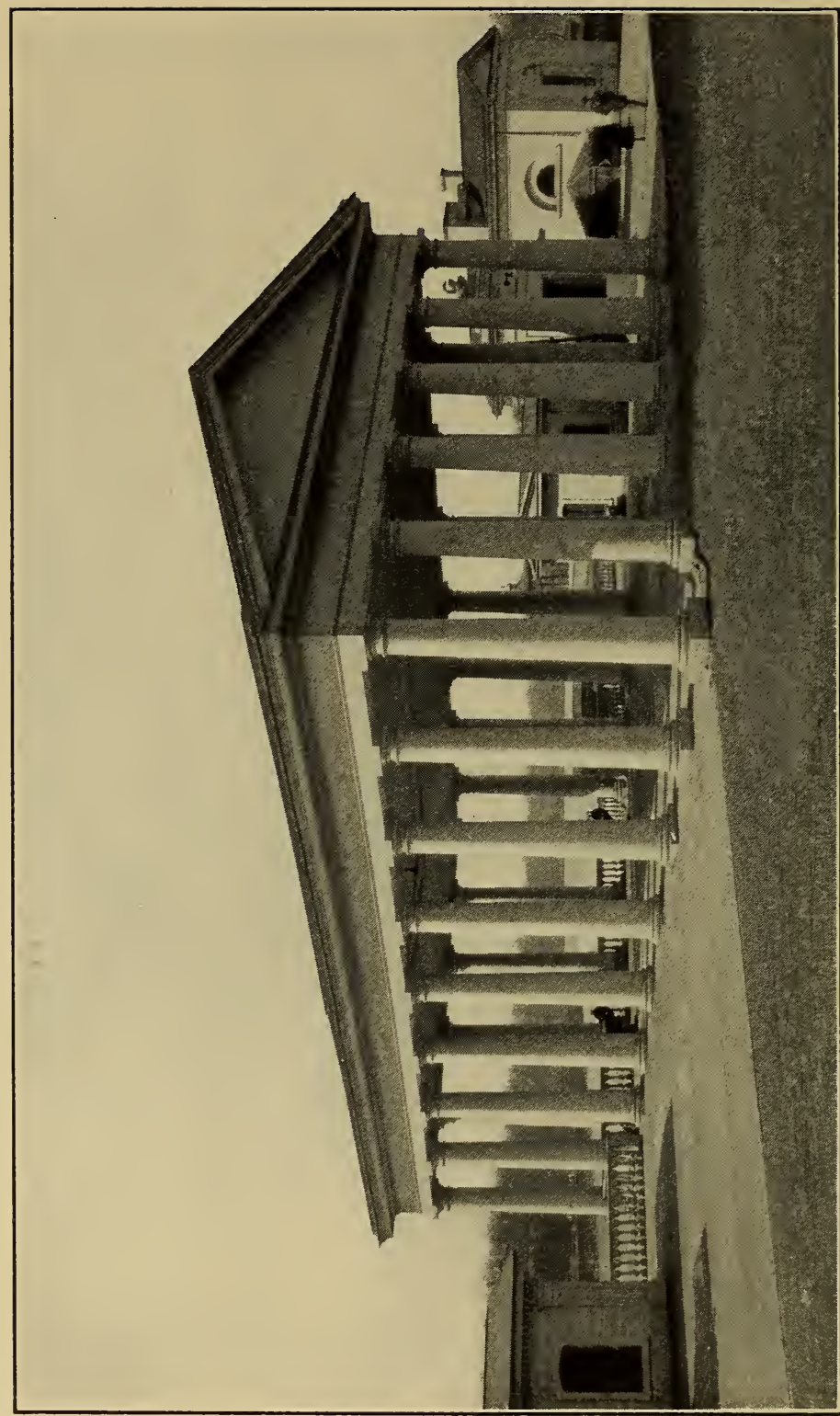

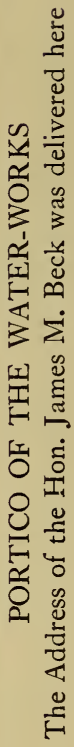


their plan of work. I can remember, although not very old, that year. It was a wonderful year in Philadelphia's history. In the first place, it was just passing from the village to the city by abolishing a volunteer fire department, whose companies were more apt to fight each other than to fight fires. It was the year when the Congress of the United States passed a resolution endorsing the project of the Centennial Exposition -not until after the display of a great deal of jealousy on the part of other American cities and states. Probably the endorsement by the national government, in March, 1871, of the project to hold an international exposition in the city of Philadelphia had much to do with Colonel Howell's fine and splendid project.

It was the year, too, when the whole world was shaken by the mighty conflict of the two great gladiators of the last two thousand years in the history of Europe-namely Germany and France - and some of us may remember in the summer of 1871, after Germany had conquered, that there was a parade in the city of Philadelphia nine miles in length, the last of the parades, which in a measure reflected the spirit of the Middle Ages; for, as I recall that parade, and I recall it well, it was the nearest approach in life to the last act of the Meistersinger, when the procession of the guilds enters the ancient city of Nuremberg. I remember the bakers throwing out the rolls, the butchers sausages, the tailors the products of their work, and I saw from hour to hour this mighty procession passing on to mark the triumph of Germany in the great war. The city of 1871 was yet very much of a village, in which for nearly fifty years there had not been the suggestion of art as an element in our civic life, but which was suddenly to spring into a new life and to undergo a new birth by reason of these two young men, hardly turned twenty years, who, though but two among 700,000 of people, determined that something must be done to redeem Philadelphia from the reproach of an excessive industrialism. So these two young men founded the Fairmount Park Art Association. All honor to them! They have deserved well of their city.

Fifty years have passed away and we their successors are met to celebrate the event, and no words of mine could be half so eloquent as that which we have seen in the journey we have been privileged to take through this noble park by the courtesy of the Fairmount Park Art Association. It is enough to say that the movement thus initiated by those two men has 


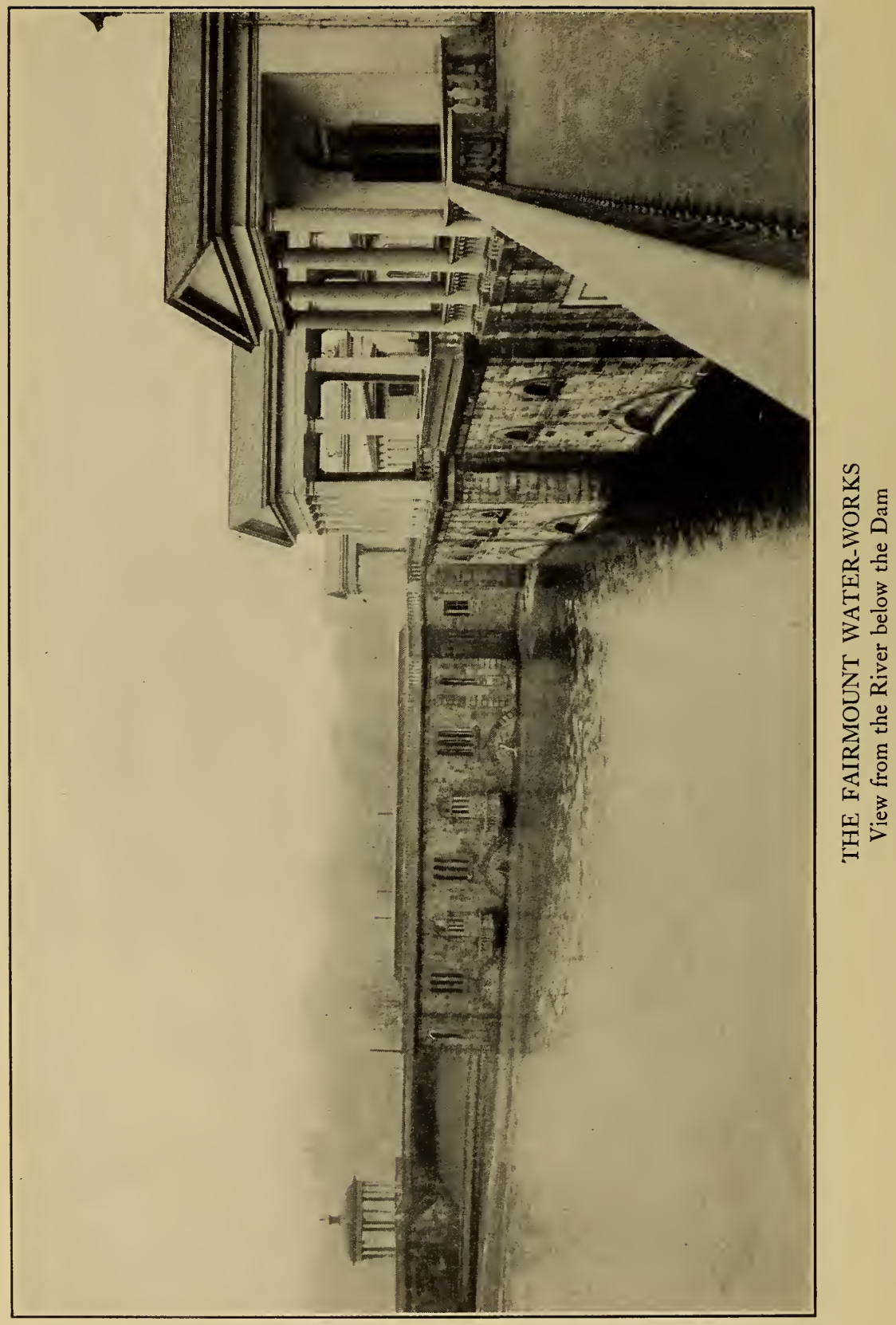


resulted in fifty works of art being given to the city and the park; that it has resulted in a permanent endowment of $\$ 130,000$; that it has influenced two magnificent gifts to Philadelphia, one, already executed, the memorial gateway at Lansdowne-the Richard Smith memorial-and the other, yet to be erected, provided by the munificence of the late Mrs. Samuel, namely the adornment of the east bank of the Schuylkill in a way that will commemorate the growth of America from the time of the Norsemen to the present age.

But, great as have been these achievements in thus amassing a splendid endowment, while giving fifty works of art to this great park-and who will say that the attractiveness of the park has not gained by it-yet the indirect influence of this Association has been even greater, for it has given a tremendous impetus to the civic æsthetic movement in Philadelphia. In no small degree the Parkway, constructed upon plans proposed by this Association and soon to be crowned by this magnificent temple of art, owes its origin to the educational work of the Fairmount Park Art Association. This marvelous parkway will be to future generations the via triumphalis of Philadelphia, as the great highway of that name was to the men of Rome, and generations yet to be born will pass up the flight of marble steps to this gracious temple now in process of erection. That, we can say without any exaggeration, is in part due to the impetus given to the æsthetic development of Philadelphia by these two young men, who thus courageously launched their project and hitched their wagon to a star just fifty years ago.

It would, however, be the sheerest flattery to say that art was born in Philadelphia fifty years ago. On the contrary, art has been from the very beginning of this historic city a great tradition and a noble impulse. You may not recall the fact, but, not long after Franklin had landed at High Street wharf, not long after the city had been founded and when the son of the first proprietor, Thomas Penn, came to Philadelphia, having then probably not 6,000 inhabitants, the leading citizens of the little village petitioned Thomas Penn to take steps to develop education and culture, so that, to use their own words, "it would make of Philadelphia the Athens of America."

Such was the expression and thus did the founders of this great city hitch their wagon to a star. And it was certainly no small art development that led a city, which at that time may have had no more than fifteen thousand people, to 
plan that venerable State House, which, if it had had no historic traditions, would yet be a very beautiful building. Mellow as it is with years, it has an artistic charm because of the dignity of its lines and the simplicity of its motive. At all events, the State House in Philadelphia, which we now call Independence Hall, planned by a man, who was not an architect but a lawyer, even as Christ Church, another noble edifice, was planned not by an architect but by a doctor-these two buildings in a city, which amounted to little more than a village, showed that there was a latent art in Philadelphia from its very beginning.

Later, in the period of Washington, when the great General and President held his court here, Philadelphia became in a sense-was in truth-the Athens of America. Benjamin West, the first American painter who ever won international renown, went abroad from Philadelphia and became not only the first exhibitor in the Royal Academy, but later, as its President, the successor of the great Sir Joshua Reynolds and for the first time drew world-wide attention to an American painter. Here it was that Charles Willson Peale - a man of varied talents - and his son, the illustrious Rembrandt Peale, Gilbert Stuart, Sully and others, whose names will readily occur to you, laid the foundations for an art in Philadelphia, that attracted attention not merely in this country, but throughout the world, and, what is more, has stood the test of time, for I think that Stuart's and. Sully's art, as shown by their lovely portraits, is not to be outclassed by anything that even Romney or Lawrence did in painting the beauties of English society.

We are, therefore, standing not only in the city that is the birthplace of American art, as it was the birthplace of American liberty, but as a matter of fact on a spot, which marked after Colonial times the cradle not only of art in Philadelphia, but of art in America; for, after the water-works were removed from Centre Square to where we now are, the first impulse to improve the city by a public park commenced, one hundred and ten years ago, where we are now assembled, when five acres of ground were acquired around the then novel water-works, and it was here that William Rush, the first American sculptor, placed the "Spirit of the Schuylkill," which still stands in its basin, only a few hundred feet away, while over the doorways to these entrances, to what were then the water-works, are the other works of Rush-one 


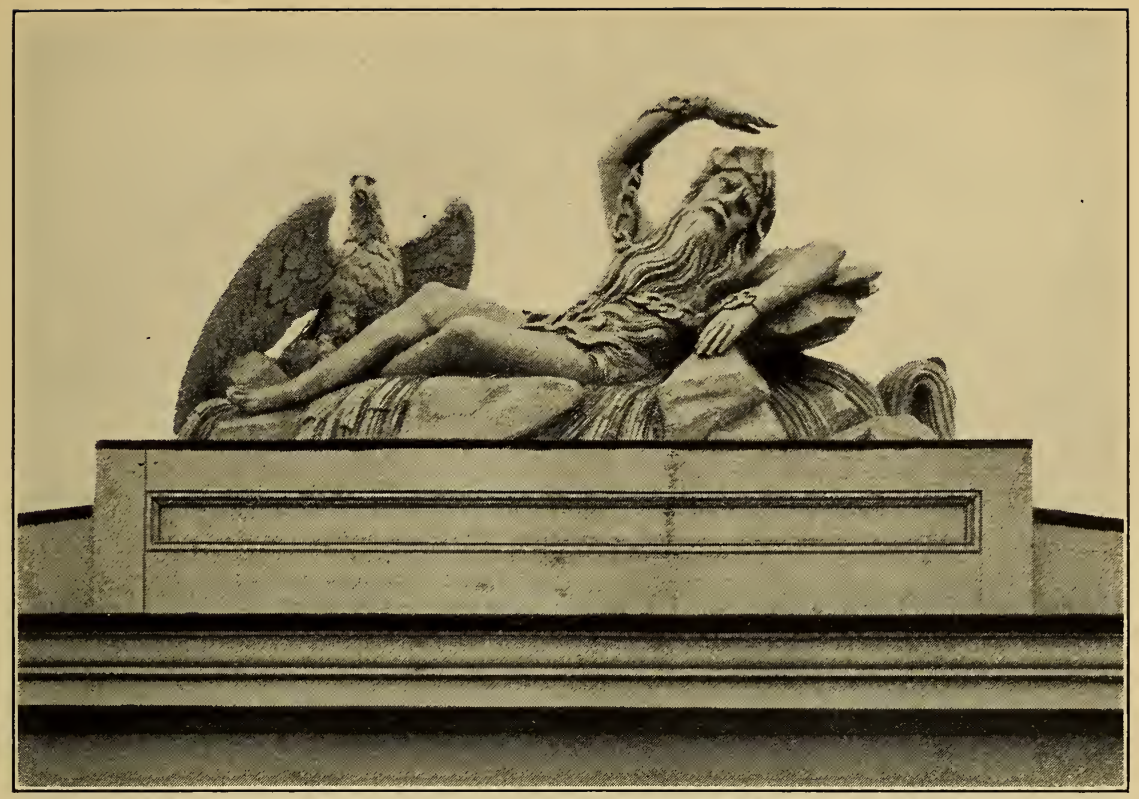

THE SCHUYLKILL IN CHAINS

Sculpture in Wood by William Rush

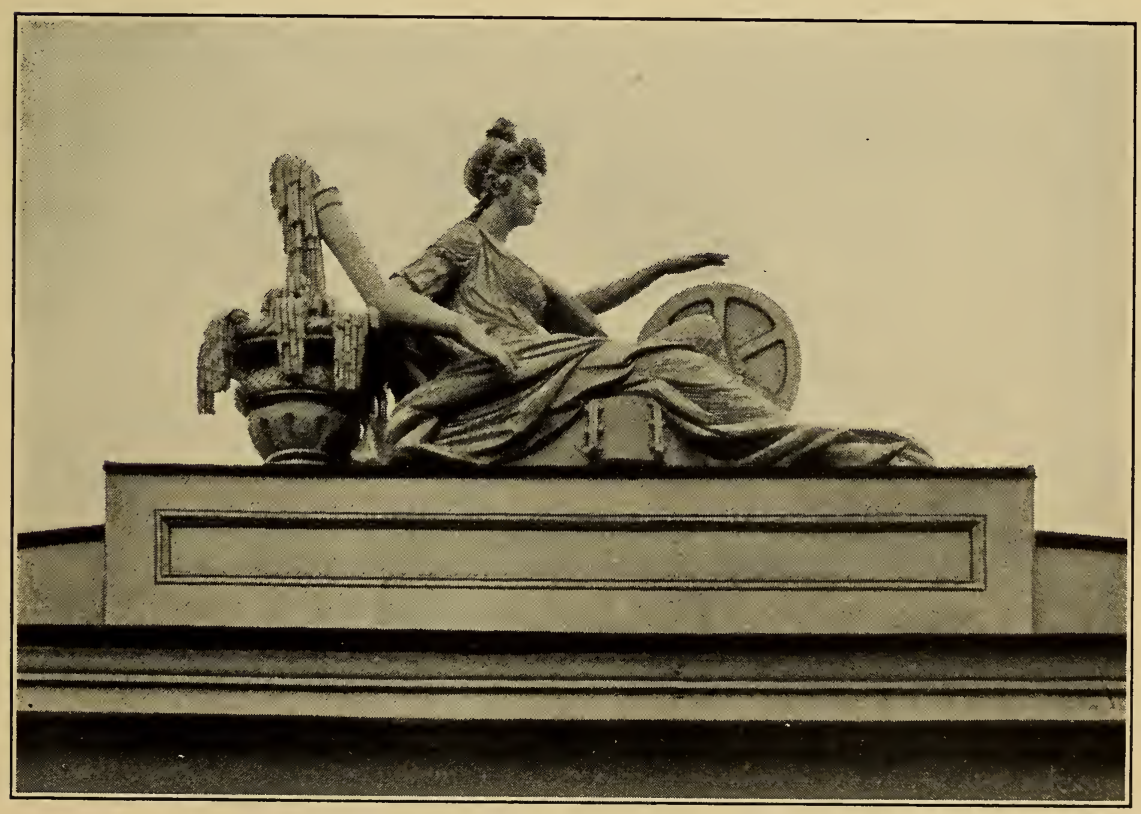

THE SCHUYLKILL RELEASED

Sculpture in Wood by William Rush 
representing the river chained by the obstructions of its rocky bed and the other the river freed from its bonds, but doing useful service through the medium of the water-works; and it is interesting to note that in the chronicles of those times it was said, referring to the "Spirit of the Schuylkill," that no greater piece of art was to be found in all the world. We may not endorse that verdict, but nevertheless it stands here as the first impulse of art in Philadelphia outside of the buildings, designed by amateur architects, to which I have already referred.

Now there came a period of time, which gives this event which we celebrate peculiar significance, for with the passing of the golden age of art in Philadelphia, with the passing of the Peales and West, Stuart and Sully, the illustrious men of that period, there came through the development of the steamship and the locomotive an era of industrialism, that lasted for nearly half a century, that submerged all the æsthetic impulses of Philadelphia and took from it its former position as the Athens of America. It was a period naturally of great industrial development. Man was harnessing the forces of Nature; he was endeavoring to take those invisible forces of steam and electricity and conquer an almost virgin continent; and it is not surprising that here and elsewhere throughout the United States the spirit of industrialism submerged the love of art. The same thing was true of Englandwhich in the same period became a great workshop. I read with great interest only a few hours ago in one of the earlier addresses made before the Fairmount Park Art Association, how, when Provost Stillé went to England before the first international exposition was held, the universal prevalence of the ugly in English life, the utter absence of anything beautiful, was noticed by him and he attributed it to the tremendous epoch-making transformation of "merrie England" into a vast industrial workshop. The same thing had happened here and for fifty years the art impulse was lost in the whirr and roar and clangor of the machines which man built up. Therefore it was that in 1871, fifty years ago, there came the first reaction against the excessive spirit of industrialism in Philadelphia, which had condemned it to be a workshop and nothing more. That reaction led the people of Philadelphia to say, "Well, after all man cannot live by the bread of industrialism alone, he must feed upon the finer fruits of the spirit, he must protest against the universal standardization of machinery, 
that is stamping out the artistic soul of the individual." And thus, responsive to the impulse, which had already found expression in the ambitious attempt to erect an ornate City Hall-and the aim was high, even though the performance in some respects lagged behind it-and in other manifestations, like the building of the Academy of the Fine Arts, there came to Philadelphia a new spirit, which for fifty years had been unknown, had lain dormant and was now revived; and, if you seek the results of that spirit, I would say to you, as the epitaph of Sir Christopher Wren under the dome of St. Paul's in London says of his monument, "Look about you."

Look at this city, with its monotonous, rectangular streets, pierced by this noble avenue of the Parkway. Look at this magnificent domain of Fairmount Park, the noblest of all the world, and here our civic pride need not fear to betray us into exaggeration. I have only recently examined two great public parks of two great American cities and today I was interested, as we rode, in contrasting them. Nothing more splendid than Fairmount Park in the infinite variety of its beauty can be seen in any city in the world, and it is this park, that this Association has enriched with statues that commemorate the great men of the Republic-statues that commemorate the great men of other nations-statues that commemorate the great ideals of humanity like Jeanne d'Arc-statues also that have no mere commemorative or historic appeal, but simply stand for the ideal of beauty in the world-the ideal of beauty that is to be a protest against the sordid, mechanical character of our time, due to a too rapid and too excessive development of industrialism.

That brings me to say the one serious thing I wanted to say, and I must not trespass upon your patience very long. I promised the Fairmount Park Art Association that I would speak upon the utility of beauty. Well, beauty is its own justification and defense. Was it not Keats who said, "A thing of beauty is a joy forever?"

I do not want, as I have on previous occasions when in this city, to argue for public improvements merely on material grounds. There is no greater asset that a city can have than its beauty. Untold millions of dollars have been poured in to the lap of Paris, because that queenly city of the Seine saw that art had a utility quite as great as any other element of human value. I do not want to put it upon that pecuniary plane, for that requires no emphasis. You and I know, that, if we want 
to attract the stranger within the gates of Philadelphia, if we want him to stay longer than his mere business interests require him to stay, if we make our city a delight to the eye, we will never lack countless thousands of strangers who will come to this city to see it, when it has some appeal to their æsthetic sense, even as they go to Rome or to Paris or as the whole world once went to Athens. Oh, I sometimes wish that I could do what Franklin wished that he could do. Mortality unfortunately forbids. I wish I could suspend animation and float, as he wished, in a cask of Madeira for a hundred years. I would like to come back a hundred years from now and walk up the Parkway, in which I trust you will permit me to say I did contribute some little modest service, for it was one of the hobbies of my youthful life and I argued for it and begged for it and pleaded for it in a number of speeches, which I inflicted on my fellow citizens, when it seemed almost hopeless to get it; but I should like to walk up that Parkway and climb at last the flight of steps that will lead to the central temple of the Art Gallery and look over the Philadelphia of a hundred years from now, which will, I venture to predict, attract a thousand strangers for every one it attracts today; for, if this æsthetic impulse be not retarded, if Philadelphia be only worthy of its splendid destiny, with all the natural advantages that have been given to it, Philadelphia can become, even as those modest founders of our city begged Thomas Penn to make it in the very days of its beginning and as it can be made, the Athens of America.

But I want, in emphasizing the utility of beauty, simply to say one thing - and I have partly anticipated the thoughtand that is this. In the last six months I have been brooding a great deal on a question which has profoundly interested me, and that is the effect of a mechanical civilization upon human character and the human soul. I have witnessed within the lifetime of men now living a revolution in human life more stupendous, more infinite in its capacity for evil, than all the changes that ever took place in the history of man from the time, five hundred thousand years ago, of the cave dweller until the present hour. All previous inventions, that had marked man's progress, were mere conquests over visible, physical nature. Today, however, he has mastered the invisible forces of nature. These have increased his power a thousand fold. He has made of himself the super-man; he has become the super-bird, brushing the eagles out of the 


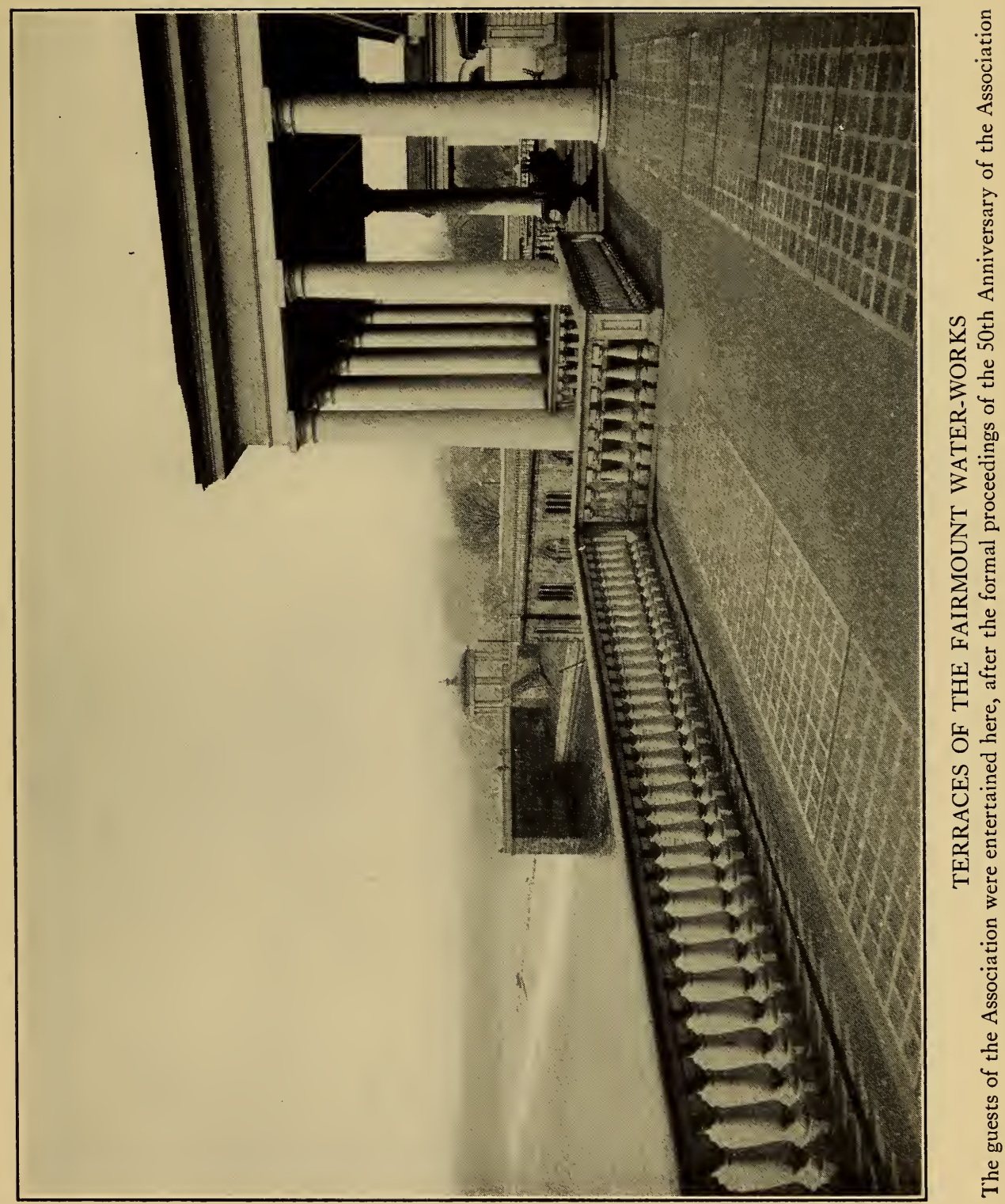


path of his aeroplane, which, directed by his swift intelligence, is but an extra-corporeal addition to his body. He has become the super-fish with his submarine. He has annihilated space with his telephone, his telegraph, and that marvelous wireless telephony, which makes the invisible "couriers of the air" the messengers of his intelligence. He has done all that, but, having done that, by the grinding force of a perfectly soulless mechanical civilization he has standardized the soul of man into a dull and almost soulless mediocrity. In other words, if I had time to enlarge upon this theme-and I have not-I think I could demonstrate to you how imperceptibly the soul of man has been crushed in the roar of the whirring machinery of his own creation. If you will read that remarkable book of Samuel Butler, "Erehwon," or the most recent contribution of Ferrero, "Between the Old World and the New," you will understand the idea that I am not developing, but simply suggesting, and that is, that the whole character of a mechanical age tends to crush the spirit of individualism; and there is nothing so fatal to art as the destruction of individualism, because the thing in human life, that best preserves the spirit of individualism, is art. Why, man has become submerged as a citizen in great groups, as a worker in great groups of workers; as a worker with his hands he has become subordinated to a machine, which he simply watches. His soul has felt the terrific crushing power of this mighty hammer of a mechanical civilization, but the one thing that machinery cannot crush is the individualism of art, for, while two artists may collaborate, one on a horse and the other on the rider of a horse, or one on the pedestal and the other on the statue on the pedestal, or even collaborate on a building, yet, in its last essence, a work of art as such must be the expression and the aspiration of an individual soul. It must be born in the man; once he has it in him, no machinery can possibly call it forth and no machinery can ever give it expression. It can imitate, yes. The mechanical piano can imitate Paderewski playing a sonata, but it is not the divine soul of the great Pole as he interprets Beethoven, as the mighty spirit of Beethoven pours from his inner soul.

You can fashion statuary by machinery, clip it by machinery, do all sorts of things by machinery, but you cannot by machinery conceive a Venus de Milo. You cannot conceive so exquisite an idea of feminine beauty by any kind of machinery that the ingenuity of man can invent. The most 
potent protest, then, against the grinding spirit of a purely mechanical age, which in itself we cannot undo, is the spirit of art. If you can develop art in the community, you can save the soul of the individual.

You talk of unrest. Why should there not be labor unrest? Why should not a man, who no longer has the opportunity to work with his muscles or soul or mind, who simply for eight hours watches a machine, that asks no advice from him, that asks no co-operation from him, that never fails, never slips, never tires, never wears out, why should not such a man resent his lot? That man leaves the factory, denied something, which is a primitive need of his nature-namely, self-expression. If he is denied that and cannot find it outside the machine that he simply watches, then that man has within him all the possibilities of the social rebel. But, give to that man, when he leaves the factory, the inspiration of art, give him something to feed the divine part of his being, his immortal soul; let him climb, as he will one day climb, the steps on yonder hill and stand under the columns of the central temple, look down the great Parkway and see everywhere before him beautiful buildings; let him do that and then he has something to feed his soul, and, no matter whether he lives in a garret or in a marble palace, he has the instinct of beauty latent within him and you have fed it and prevented it from being starved.

That is what $I$ had in mind in suggesting the utility of beauty - that it is no mere luxurious pleasure or love of adornment, that leads us to erect this statue or that lovely fountain. We are not only doing what is good for ourselves, but we are doing the most truly democratic thing in the world. And why? Works of art, such as the Fairmount Park Art Association gives, are what all classes of men in the nature of the case share on the basis of absolute equality. You have a private art collection and it is your own. You have lovely adornments for your house; they are your own. You build a great church and only its own adherents go into it. You create a symphony orchestra and only the subscribers can hear it. But have you ever thought of the countless millions of children yet unborn, who in the hot days of summer will stand around the fountain in Logan Square and hear those splashing waters and feel their little souls refreshed by the psychological effect of falling water? Or have you ever thought in connection with these works of art, which this Association has given to the city, of the stimu- 
lus to the people who come and throng this park? The poorest child from the slums, as well as the child of the multi-millionaire, can see without money or price something which is a stimulant to his idea of beauty and develops in his soul that which otherwise might starve

I shall only suggest one other thought and I trust you will bear with me, because it is perhaps more practical than that, which I have just been saying. We have with pardonable pride felicitated ourselves this afternoon on a great work, begun fifty years ago and hitherto showing great results. When the annals of Philadelphia come to be written, it will be no mean chapter that records the beginning of the Fairmount Park Art Association. But, let me say, I think we should mingle our justifiable jubilation with a little diffidence, for, great as is the work that we have done, it is nothing to what we could have done and should have done.

Do you realize that this Association in the first year of its existence had 750 members? Today it has 350 . Seven hundred and fifty members in a population of 700,000 people and only 350 in a population of $1,800,000$ ! Do you know that there never was a time in the city of Philadelphia from the birth of this organization, with its elective dues of either one dollar for an associate member or five dollars for an active member, that there were not countless thousands, who ought to have joined the Fairmount Park Art Association because of its universal appeal to civic spirit?

I think in that respect we have made a mistake and I think it was a natural mistake, because it came in the very beginning of this organization; as expressed in one of its first announcements, it was to be an organization of "ladies and gentlemen." That meant it was to be a social organization of Philadelphia, made up by its so called best people and administered by them. Now is it not true that there are at least 10,000 people in this city, who would willingly contribute five dollars a year to this organization, in whose benefits they are sharing every time they walk its streets or traverse its park? Is it not likely that there are 20,000 , who could spare one dollar-less than half the cost of a theatre ticket-to contribute to that which would be a lasting joy?

This Association, instead of having, as it now has, about $\$ 7,000$, or we will say $\$ 10,000$, of income from its dues, with an ultimate but sure endowment of $\$ 30,000$ a year from Mrs. Samuel's bequest-this Association ought to have $\$ 50,000$ a 
year in dues and, if it had that amount, in fifty years it could transform this city. It has already with its meagre membership, that has rarely gone beyond a thousand members at any one time in the whole fifty years of its career, transformed the park and is beginning to transform the city. But, if we could each year erect such statues, as could be secured by cooperative effort, within fifty years we would hardly know Philadelphia, and then indeed, if we could come out of Franklin's cask of Madeira, we would see a change extraordinary and most beneficent in its possibilities. On this Fiftieth Anniversary of the Association we ought to take a high resolve, that no longer will we be an association of merely "ladies and gentlemen." Let us be one of citizens. Let us be a civic association, to whose membership all are welcome, and let us go out into the highways and byways and appeal to the people of Philadelphia to contribute a dollar apiece, if that is all they can contribute, or five dollars, if they can, and let us get a fund that will move forward with a rapidity, to which even the past would seem slow.

Is it impracticable? Why is it no one deems it impracticable to appeal to your churches, to your Chambers of Commerce, to your Bourses, to your great Manufacturers' Cluball the clubs-to the women's organizations, who, as in the case of the Symphony Orchestra, raised a million dollars in a few months? Let us appeal to all the civic activities of Philadelphia, never so active as at this moment, and let us say to them, "This is one thing in which all of you, whatever your special interest may be, ought to be interested." Suppose we had \$50,000 a year to spend. In two years we could build a Greek theatre against that hill, looking down upon this portico as a stage, in which an orchestra could play, a classic performance be given, or public meetings be held.

Consider this lovely development of the Schuylkill River as far as the Callowhill Street bridge. And, then, looking from one picture to another, look at the hideous neglect of an opportunity beyond. These old fathers of ours, who put up this balustrade and adorned the five acres which were the beginning of the Fairmount Park, where we now stand, had a sense of art, which I think it would be idle to depreciate. As far as the Callowhill Street bridge, the development is beautiful. South of it is an eyesore of neglected river banks. Heaven grant they may be redeemed.

But the work has not yet been done and I suppose some- 
one here, if he came from another city, would say Philadelphia is too slow. Philadelphia is not too slow. Philadelphia is not slow at all. A city that can develop from seven hundred thousand to a million eight hundred thousand people in fifty years and whose industries are among the greatest in the world is not slow. But Philadelphia, like every great historic city, lacks the sense of the passing of time. I remember once asking a great Italian in Rome what he thought of a distinguished American-President Rooseve't-who had just left Rome after coming up from Africa. He looked at me in a pitying way and he said, "Mr. Beck, from the background of our 2600 years of history, Colonel Roosevelt seems small." Then I realized what it must be to have a civic consciousness, which runs for twenty-six centuries and which feels therefore, "Well, if this generation does not do it, the next will, and, if the next won't do it, the following one will. I may not be here to have it, but I am a citizen of Rome, I enjoy all that was ever past and I am going to enjoy all that is future."

That is the feeling of every great historic city-of Rome, Paris, London; it is the reason why the great cathedrals, that are the despair of the architect, like the Milan and the Rheims cathedrals, were so long in building; it was nothing to any generation that it did not live to see them finished. What they were concerned about was that sufficient time should be taken, because centuries were nothing to a city that lives for centuries.

Take a city like Chicago; it has no such time sense, it cares nothing about what happened last year and little about what will happen tomorrow. What it wants is to do it today. "Let us see it and get done with it." When Chicago says, "I will," it begins and ends an improvement, while we are still dreaming about it. That does not mean that we are unfortunate and they fortunate in this different point of viewnot at all.

Do you know that it has been a great blessing that Philadelphia has had this time consciousness and has rarely done things too quickly? If we had not been quite so hasty with the City Hall, we should have had a better building. If we had planned and built the Parkway, when I, among others, urged it, it would have been a one hundred feet wide street and nothing more and, while it would have been a great improvement, it never would have been the stupendous thing that it has become. There is not a city in the world, which has done anything upon such a splendid scale, since Baron 
Haussmann revolutionized Paris. There are improvements, as in Washington, with open spaces, or in Chicago, with the open lake front, but in the tearing down of thousands of buildings and the building of a great avenue, which will last for centuries, the Parkway has developed by mere patience into a work of stupendous magnitude.

I can remember, when we wanted to put the Art Gallery on Lemon Hill. The design then selected was as nothing compared with this magnificent design, that, to the honor of Philadelphia architects, has been provided for future generations. -I was impressed, when I walked over the foundations of this building, with the fact that for centuries to come it will not outgrow the space. It is built, not for tomorrow or the next decade or for the rest of the century. That building is built, as the Parkway is built, to stand for centuries and to be the admiration of untold generations of Americans in the indefinite vista of the future.

So there is some advantage in the fact, that Philadelphia with its historic consciousness, is not particularly concerned whether this generation does the work or the next one. And yet that attitude has its disadvantages; it enormously multiplies the expense; it denies us, who are, like Dante, past the middle of lite and find ourselves in a dark and sombre wood of gathering years, the pleasure of seeing of the travail of our soul and being satisfied.

For my part, therefore, I would like to see the golden mean between the two extremes of too little sense of time, as in Chicago, and too great a sense of time, as in Philadelphia. Certainly I would have this Fairmount Park Art Association, as it enters upon its Fifty-first year, resolve that, instead of appealing to a membership of three hundred and fifty people, it shall have a membership so large, so representative of all classes, all conditions of the community, that it will be the great co-operative civic institution, which it was originally planned to be and which, with the wealth that would flow in by an enlarged membership, could and should each year do something that will add materially to the beauty of this city.

Now, ladies and gentlemen, I have taken far too long, I know. It is an interesting occasion and the beauty of the surroundings and the compliment you have paid me by your kind attention have perhaps encouraged me to prolong my remarks unduly. Let me end my little talk by saying, what I have often said-I apologize for repeating it, but it is a thought so beau- 
tiful to me, that I have rarely spoken on this subject without the thought coming unbidden to my mind-and that is, that Philadelphia is the one American city with a Greek name to suggest the culture of Athens. Its early founders planned that it should be the Athens of America. Charles Willson Peale, in his old age, also expressed the hope of seeing the day when Philadelphia should be the Athens of America. Its Greek name is an inspiration and let us therefore hope, that once again in this new world, with all its magnificent possibilities of art, that once again in this most historic city of the new world, there shall come to pass, as was once in ancient Greece, a new "city of the violet crown." 
THE STORY

\author{
of the
}

FAIRMOUNT PARK

ART ASSOCIATION 


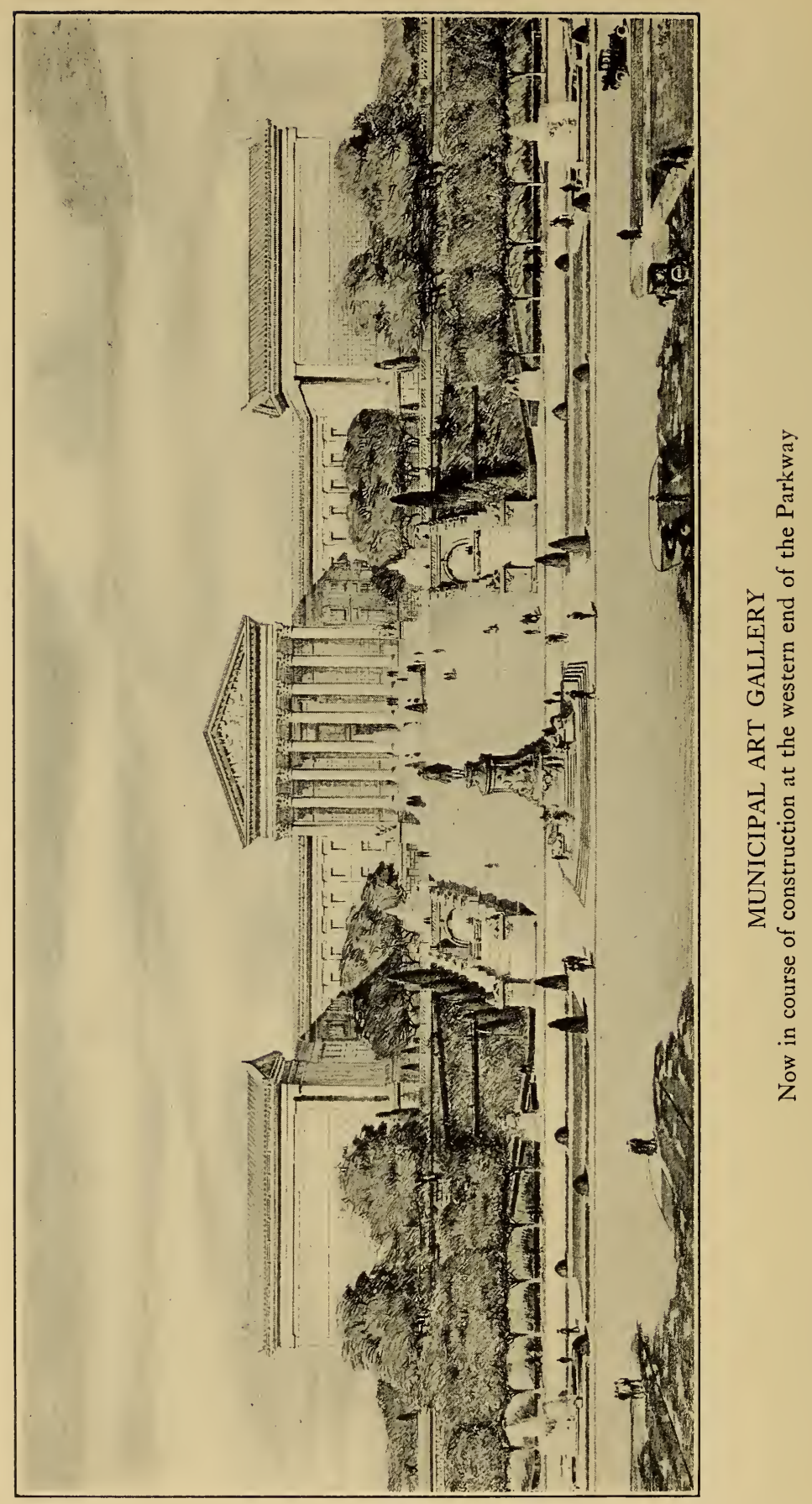




\section{HISTORY}

of the

\section{FAIRMOUNT PARK ART ASSOGIATION \\ by}

\section{CHARLES J. COHEN, President}

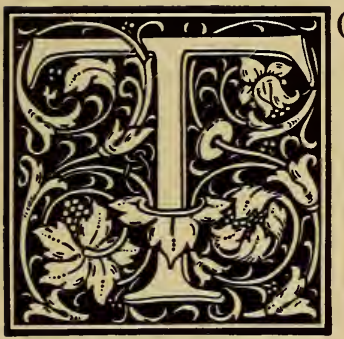

O commemorate the Fiftieth Anniversary of the founding of the Fairmount Park Association a brief account has been prepared of its origin and activities during the half century of its existence. Short biographical sketches have been introduced describing the original Board of Trustees and the several Presidents, who have occupied that office, and special accounts of individuals where special service to the Association seemed to warrant such action.

During the spring of 1871 two neighbors, Charles $\mathrm{H}$. Howell and Henry K. Fox, conversed frequently about the future development of Fairmount Park and the possibilities of its adornment by statuary and other works of Art. Extensive plans for the Park had just been completed and the land required for it acquired, notwithstanding great opposition from many citizens, who regarded the expenditure as an unwarranted outlay of municipal funds.

All honor should be accorded the memory of the men, who fought valiantly for this unrivalled pleasure ground, and it is fitting that the names of those composing the first Board of Commissioners of Fairmount Park, men who served without compensation and who with their successors up to the present have maintained an unbroken record of distinguished achievement, should be recorded.

Prior to the appointment of the Commission, publicspirited citizens had urged the creation of the Park. The late Ferdinand $\mathrm{H}$. Dreer made this statement at the annual meet- 
ing of the Fairmount Park Art Association, December 1, 1895 :

"I want to state as a fact, now but little known, that it was largely due to the unremitting exertions of Charles S. Keyser and James H. Castle, that we are indebted for our Park. For, in 1855, and even prior to the consolidation of our City, they were untiring in their efforts to arouse public sentiment in favor of such a resort, and I know that it was through their energy and continued work that our City's pleasure ground was at length secured." in 1867:

Original Commissioners of Fairmount Park appointed

ELI K. PRICE

JoHN WeLSH

William Sellers

Joseph Harrison

JoHn C. CREsSON
N. B. BROWNE

Theodore Cuyler

Henry M. Phillips

Gustavus Remak

George G. Meade

The members ex officio were:

Morton McMichael, Mayor

Joshua Spering, President of Select Council

Joseph F. Marcer, President of Common Council

Charles Dixey, Commissioner of City Property

Frederick Graff, Chief Engineer of the Water Works

Strickland Kneass, Chief Engineer of the City

The first meeting of the Commission was held on June 3, 1867, at which the above-named were present. The following officers were elected:

Morton McMichael, President

George G. Meade, Vice-President

James F. Marcer, Secretary

N. B. Browne, Treasurer

\section{THE FOUNDING OF THE ASSOCIATION}

\section{1}

In June, 1871, fifteen gentlemen consented to act as temporary officers and trustees of the proposed Fairmount Park Art Association. Drafts of Preamble, Constitution and By-Laws were prepared and on the 22nd of June a subscription book was opened and over two hundred became members of the proposed Association.

On September 27th the Board met at the office of the Commercial National Bank, 314 Chestnut Street, adopted the 
report of the Committee on Charter and made formal application to the State Legislature for the Charter, a requirement that has been superseded under the amended constitution of 1874 .

The Preamble* and Constitution were adopted and the following Officers and Trustees were elected:

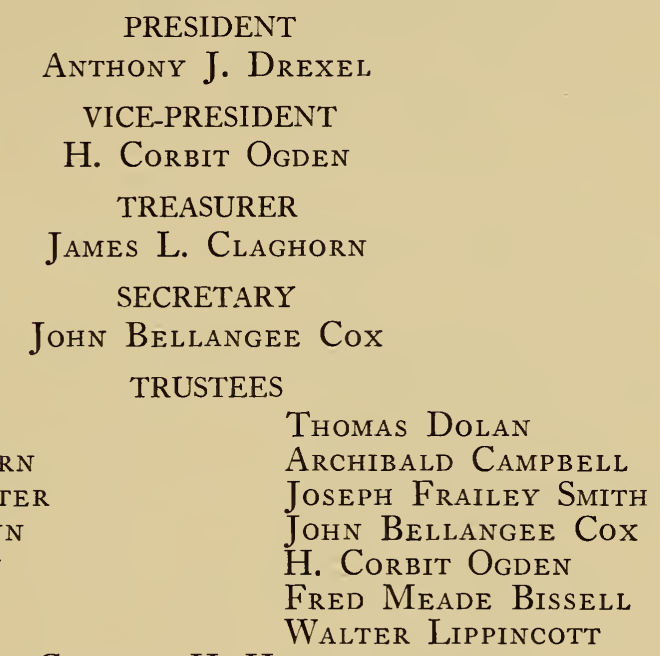

Charles H. Howell

A. J. Drexel

James L. Claghorn Edward H. Trotter Wm. J. Horstmann Henry C. Gibson Samuel S. White Henry K. Fox
ThOMas Dolan

Archibald Campbell Joseph Frailey Smith John Bellangee Cox H. Corbit Ogden WaLter LipPincotT

A notice stated:

"The Charter may be signed at Bailey \& Co.'s, Twelfth and Chestnut Streets; J. E. Caldwell \& Co.'s, 902 Chestnut Street; J. S. Earle \& Son's, 816 Chestnut Street; C. H. \& H. P. Muirhead's, 205 South Sixth Street; and at the Office of The Association, 528 Locust Street."

It is a notable fact that, notwithstanding the great activities and prominent position held by Anthony J. Drexel in the community, this was the only Association (with the exception of the Drexel Institute), of which he at any time would accept the Presidency, and he remained in that position until his death.

Of those original members, the only one who has survived to the present day, still retaining his membership in the Board, is Henry K. Fox, who tells of his early friendship with Charles $\mathrm{H}$. Howell and of an informal meeting at their home, where they discussed the possibilities of interesting the members of the community in such an undertaking. Shortly

\footnotetext{
* See page 262
} 
1.2. 4

Arme.

Leequer office

1102 Lumacpas.

$140 \mathrm{t}$ Halnut

3493 Tred

3 A Prexde

314 Chetmis of

5 of Propie

6 Demulg bivino
1025 Prean Rí.

$1 / 12$ Sraluat 2t.)

7 YVeny demis 10.10 thath

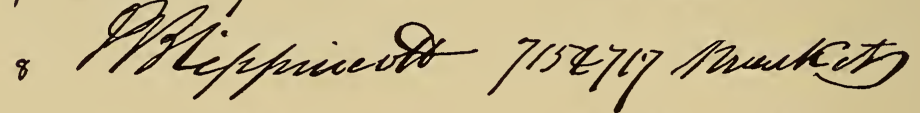

9 Ym. A. Beustmann Pifor Mbring Sis.

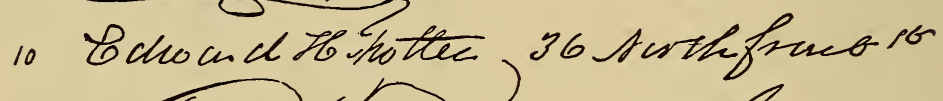

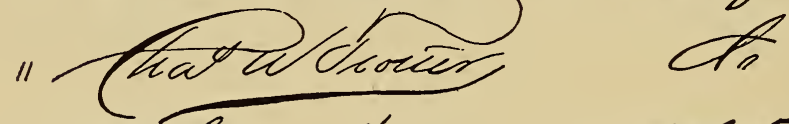

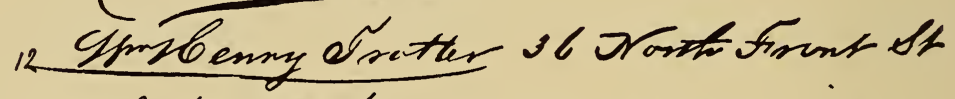
13 Ootur. Stewis 231 fo:bunhth

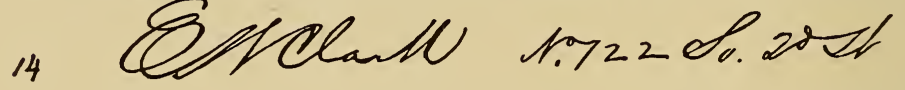

Reproduction of the signatures of the first members of the Association.

34 


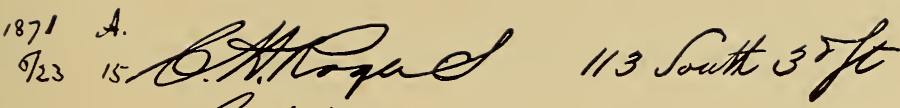

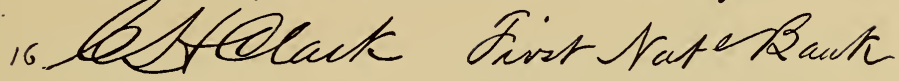

-17 Pa. Saurela

Wosam tarisont

18 SfCt.balduen

Ees Chestrnith

19 Ohach LShafilen ger

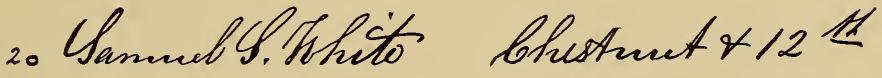

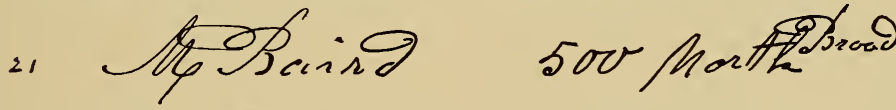

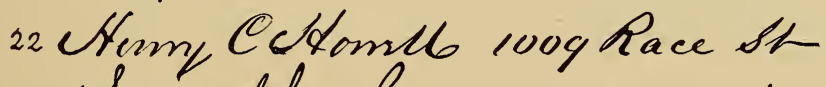

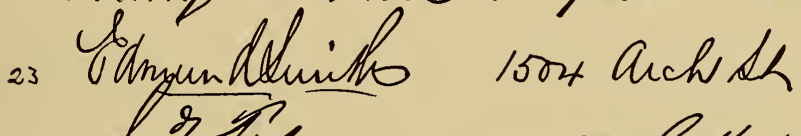

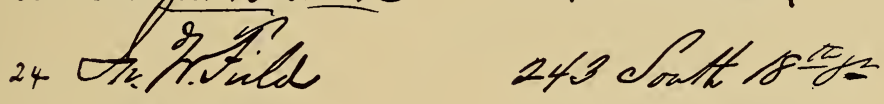

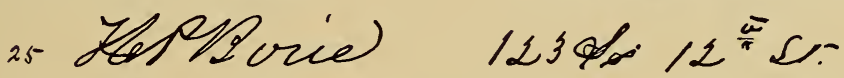

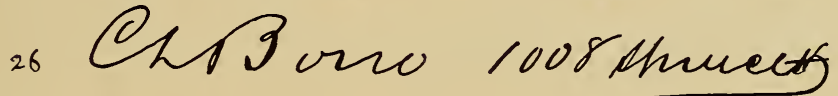

27 Gdumbliter sopley Mperen thet.

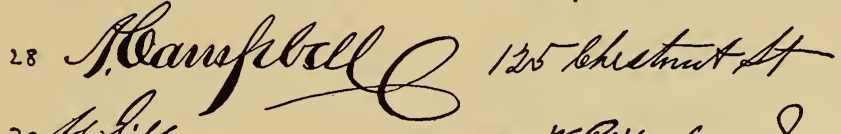
2q Alusibbous.

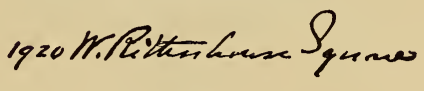

Signatures of the first members continued.

35 


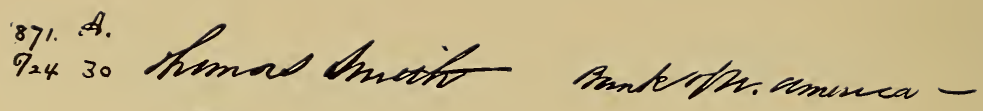

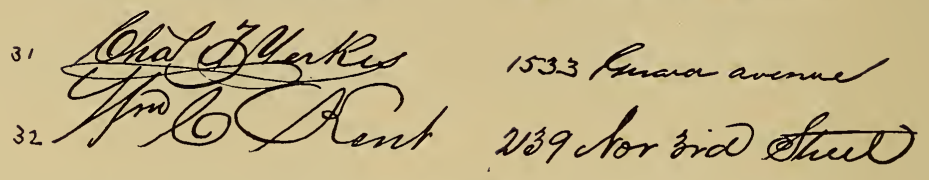

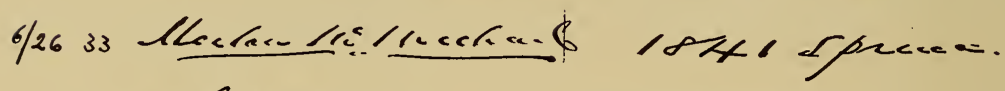

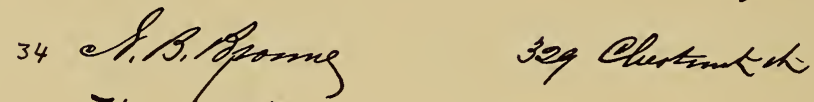

35- Vied uyth

yoy Waluent the

- 36 preeustrall

$6 / 27$ s) Glipt.sicel,

b3y arch stiut

709 Prremut breat

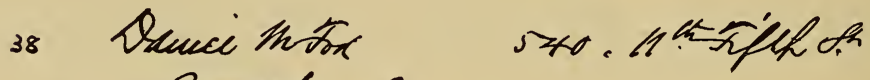

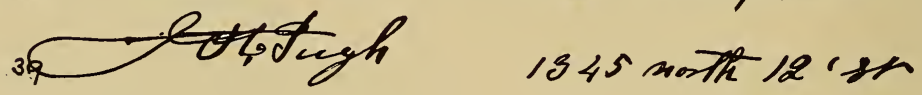

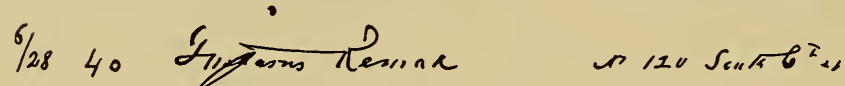

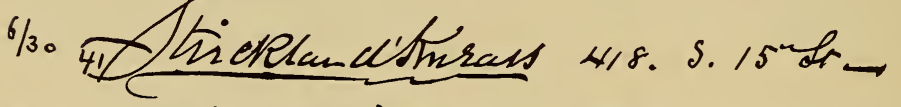

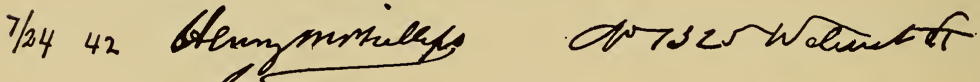

43 Acmplattety sto $26 y$ nth 41 st -

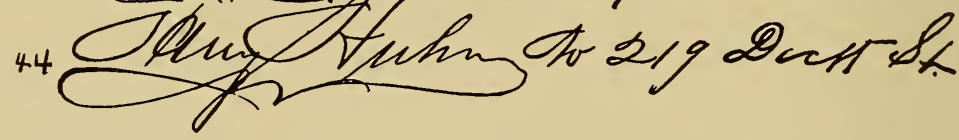

Signatures of the first members continued.

36 
thereafter Mr. Fox had married Miss Eliza H. Landell, whose father was of Eyre and Landell, well known merchants at Fourth and Arch Streets. Mr. Fox was the son of Daniel M. Fox, a distinguished member of the bar, who was Mayor of Philadelphia during the years 1869 to 1871 and who seconded his son's ambitious effort toward his desired goal.

\section{2}

In February, 1872, suitable By-Laws were adopted. Edwin N. Benson was elected an honorary member; William S. Baker, Anthony J. Drexel, James L. Claghorn, Henry C. Gibson and Charles H. Muirhead, all men closely identified with art interests in Philadelphia at that period, were elected life members.

The first annual meeting was held Tuesday, October 15, 1872 , at 8 o'clock in the evening, in the room of the Board of Trade in the Mercantile Library Building, Tenth Street above Chestnut Street. It was presided over by Joseph Patterson, a distinguished banker, President of the Western National Bank (then situated on Chestnut Street above Fourth, adjoining the United States Custom House on the west), and a man highly considered in Philadelphia; he enjoyed a national reputation, having been closely associated with the Secretary of the United States Treasury in floating Government loans for the conduct of the Civil War.

At this meeting an address was delivered by the Hon. Benjamin Harris Brewster, the quality of which would appeal to the present-day reader. This was followed by annual meetings in regular course. One address was given by the Hon. Joseph R. Chandler, identified with the Philadelphia North American, and a man held in high esteem for his character and literary qualifications. Other addresses were delivered by Henry C. Carey, a noted book publisher and literateur, and by Charles J. Stillé, Provost of the University of Pennsylvania.

The Board of Trustees now met monthly at the office of the Commercial National Bank at the corner of Chestnut Street and Hudson's Alley (now Orianna Street), No. 314, of which institution Mr. James L. Claghorn, then Treasurer of the Association, was President.

The first undertaking of magnitude was the formation of a committee to erect a statue of Major General George Gordon 
Meade, the hero of Gettysburg, who had recently died, and whose memory was precious to Philadelphians, since his able conduct of the battle had ensured the safety of the City at that critical period of the War. The fund of approximately twenty thousand dollars, after much discussion, had been invested in United States $10 / 40$ bonds at a price slightly exceeding par, which action was severely criticised by some members of the Board, inasmuch as the belief prevailed that a much higher rate of interest could have been obtained from other securities, of which there were many offerings at that time. However, an appeal was made to Mr. Drexel, who approved the investment; and it proved profitable, inasmuch as the bonds advanced to a price of about 120 and when disposed of added materially to the principal of the fund.

This is mentioned as an endorsement of the conservative policy that has guided the administration of the funds of the Association. The policy was subsequently embodied in the By-Laws and has resulted in a gratifying aggregation of permanent funds.

The total number of members of the Association at that date was two hundred and thirty-one. Mention is made of a special donation from Edwin N. Benson of $\$ 500$.

The following officers were elected for the current year:

Anthony J. Drexel, President

James L. Claghorn, Treasurer

John Bellangee Cox, Secretary

The Committee on Ways and Means were:

J. Frailey Smith, Chairman
Charles H. Howell

Walter Lippincott $\quad$ H. Corbit Ogden

The Committee on Works of Art were:

Henry C. Gibson, Chairman

(who later resigned and was succeeded by)

Chapman Biddle, Chairman

William J. Horstmann, deceased succeeded by

Charles H. Rogers

James L. Claghorn

Samuel S. White

Edward H. Trotter
Edwin N. Benson

Joseph Patterson

M. BAIRD

The Auditing Committee were:

Henry K. Fox

Walter Lippincott 
At the first annual meeting announcement was made of the purchase of the bronze piece, "Two Hudson Bay Wolves," by Kemeys, which was mounted and placed at Lansdowne entrance, West Park.

Two members of the original Board died during the year, Edward H. Trotter* on May 3d and William J. Horstmann** on May 10 th.

At the meeting of the Board held November 9, 1872, the committee for the memorial to the late Major General George Gordon Meade was appointed, the Association agreeing to contribute $\$ 5,000$ toward the fund. The committee was as follows:-

Chapman Biddle

Charles H. Rogers

\section{Archibald Campbell, Chairman}

J. Frailey Smith

Charles H. Howell

\section{4}

By act of Congress, approved June 22, 1874, the United States gave to this Association "twenty twelve-pounder condemned bronze cannon, to be used in erecting a bronze equestrian statue to the memory of the late Major Gen. George Gordon Meade within the limits of the City of Philadelphia."

At the meeting held December 16, 1874, the following action was taken:

" 1 . That the Treasurer set apart $\$ 3,000$ of the funds of the Association as a foundation for a permanent fund.

2. That the Treasurer shall hereafter add to this said permanent fund all the sums of money hereafter received from life membership dues together with 10 per centum of all dues received from annual members and all special contributions, bequests, etc., except such as may hereafter be otherwise disposed of."

This was the beginning of the permanent fund that has now reached the proper total of upwards of $\$ 120,000$, the accretion being largely due to the personal effort of the late Charles H. Howell, who visited his many friends, explaining the value of a permanent fund, the interest of which might be used only after the principal had reached the amount of $\$ 100,000$; this feature appealed to public-spirited men of the day and the result was as announced.

* For Biography, see page 111.

** See page 103 . 
Archibald Campbell, a member of the original Board, died December 23, 1874.*

\section{5}

The Bronze Group, “The Dying Lioness," by Professor Wolff was purchased and subsequently placed on the Concourse, on Girard Avenue, in front of the Zoölogical Gardens.

\section{6}

The Centennial Exposition of 1876 gave an impetus to the creation of art work as well as to a greatly increased interest on the part of the average citizen in the decoration of the Park and in art work generally. The minutes of the Board of Trustees are replete with evidences of this interest, which developed into accessions of art works decorative to the Park and interesting as historical memorials.

\section{7}

The following paragraph, quoted from the annual report presented November 26,1877, stimulated action toward the completion of the fund for the statue of General Meade:

"It is becoming popular, and perhaps it is proper, to forget the acrimonious issues and to cover up the wounds of civil strife, but there is no patriot who can wish to extend this oblivion to the memories of the heroism displayed in that fearful contest. It is the duty of every citizen and to the interest of the republic to treasure up such memories and seek to perpetuate them in repositories, which, defying the approaches of Time, will memorialize youth and growing manhood that it is a good thing to serve one's country well in the hour of its supreme trial and danger."

In 1877 five fountains were purchased in Paris; they had been cast at the Foundry of Val D' Osne; two were placed on East River Drive below Girard Avenue Bridge and three near the Lincoln Monument.

The Trustees of the Franklin Institute presented the sculptor Thom's group of four figures in sandstone, "Tam O'Shanter," illustrating a scene from the famous poem of

* See page 85 . 
Robert Burns. This is placed on the East River Drive, under a rustic shelter, ${ }^{*}$ opposite the boat houses.

\section{8}

In the minutes of the Board, January 5, 1878, the following phrase occurs:

"Advisability of selecting such works as would illustrate and perpetuate the early history of this country."

It is possible that this sentiment acted as a suggestion to the late Mrs. Ellen Phillips Samuel, when she drew her will bequeathing to this Association nearly her entire fortune of upwards of $\$ 765,000$ for this express purpose, to which reference will be made later.

In the same year the Board decided that it was expedient to contract with native artists in further commissions. This is always a moot question, since art knows no nationality and the best should be available; but, while selection of artists should not be restricted to one's own country, it does seem imperative that native artists should be encouraged by commissions wherever practicable, since it is self-evident that art cannot flourish unless supported by proper financial returns.

\section{9}

On the 30th of December, 1879, Samuel Stockton White* died in Paris, France. Mr. White was one of the original Board of Trustees.

\section{0}

A large fountain was purchased and placed near the Dauphin Street entrance to the East Park at a short distance south of Woodford Mansion.

Mr. Joseph Frailey Smith** died June 26th.

Colonel Chapman Biddle died December 9th. Colonel Biddle was an eminent citizen, prominent at the Bar and loved and respected by the community. He became a Trustee shortly after the organization of the Board and aided to a marked degree in the establishment of the Society.

* Built from a design prepared by Charles M. Burns, Architect. All the works in sculpture, secured by this Association, are reproduced herein. Reference to the pages may be found in the Index.

* See page 113 .

** See page 109 . 
On October 27th, the Board inaugurated the movement for a Garfield Memorial Fund.

\section{$1882-83$}

It is desirable to note the beginning of the conservative action in the matter of investment that inspired confidence in the minds of the general public. At the meeting of the Board of Trustees, December 18, 1882, the following motion was offered, "that the Treasurer be directed to invest all amounts of Five Thousand Dollars and over, that may accrue in the various funds of this Association, in United States, State of Pennsylvania or City of Philadelphia securities." After discussion, it was laid over to the next meeting, at which time, January 9, 1883, it was resolved, "that the Treasurer is hereby instructed to invest all sums of "Two Thousand Dollars and over of each of the various funds in United States Treasury bonds, Pennsylvania State bonds or bonds of the City of Philadelphia, to the credit of the respective funds."

It may be stated that the cause of this action was an investment of a considerable sum as a call loan without security, an action reprehensible for an organization of this character.

\section{4}

In 1884 the group of "Orestes and Pylades" was purchased and erected as a fountain near Columbia Avenue entrance to the East Park.

James L. Claghorn* died August 25th. Mr. Claghorn was one of the founders of the Association and was Treasurer from its inception.

\section{5}

In 1885 the group, "Silenus and the Infant Bacchus," attributed to Praxiteles, was reproduced in bronze by Barbédienne of Paris from the original in the Louvre. It was purchased and erected on the East side of the Main Drive near the Brown Street entrance to the old Park.

"The Wrestlers," reproduced in bronze by Barbédienne, Paris, France, from the original antique in the Royal Gallery of Florence, Italy, was presented to the Association by Mr. Anthony J. Drexel. It was mounted on a pedestal of granite on the West side of the Main Drive, at the foot of Lemon

* See page 87 . 
Hill, near the Brown Street entrance to the old Park, in November, 1885.

\section{6}

At the annual meeting, held March 24th, the following Resolution was adopted:

"Whereas The Board of Trustees, on the sixteenth day of December, A. D., 1874, established the Permanent Fund by resolving in the words following:

1. That the Treasurer set apart $\$ 3000$ of the funds of the Association as a foundation for a Permanent Fund.

2. That the Treasurer shall hereafter add to the said Permanent Fund all the sums of money hereafter received from life membership dues, together with ten per centum of all dues received from annual members, and all special contributions, bequests, etc., except such as may hereafter be otherwise disposed of.

And Whereas It is desirable that the said Permanent Fund shall be by this Association declared inviolable;

Therefore be it Resolved, That the principal of the said Permanent Fund shall never be expended or reduced for any purpose whatever.

Resolved, That the interest of the said Permanent Fund shall not be expended for any purpose whatever, and that it shall be accumulated and added to the Fund and be made part of the principal thereof, until this Association shall order it otherwise."

At a meeting of the Board, held on November 22d, Mr. John Bellangee Cox, who had held the office of Secretary for fifteen years, presented his resignation of that office on account of pressing business engagements. It is eminently due to the memory of $\mathrm{Mr}$. Cox that the following resolution, unanimously carried at that meeting, should be re-published.

"Resolved, That the Board of Trustees of the Fairmount Park Art Association, acknowledging the imperative reasons given by Mr. Cox for resigning his office as Secretary of this Association, accept his resignation with profound regret.

"RESOLVED, That this Board, desiring to record their appreciation of his valued and long-continued services, hereby appoint Mr. Cox Honorary Member of this Association."

The Women's Committee for the Meade Memorial was formed with Mary McHenry as Chairman and Louise E. Claghorn as Secretary and Treasurer; Miss Claghorn was a sister of James L. Claghorn, the Treasurer of the Association. The women set to work with enthusiasm and succeeded after a comparatively short time in raising the necessary fund, so that the committee issued invitations to sculptors to prepare and submit designs; and the women, having secured the neces- 
sary fund, claimed the privilege of sharing in the selection of the sculptor; this was an innovation that the members of the Board had not anticipated and one that at first encountered opposition; it was only after days of mediation between the two bodies that the Board was finally persuaded to accept joint action with the Women's Committee.

This was an anxious period, but the difficulty was solved, a number of designs received and the successful sculptor, Alexander Milne Calder, was awarded the commission; and the statue now stands in that portion of the Park between Memorial Hall and the river.

\section{7}

The unveiling of the Meade Memorial took place Tuesday, October 18, 1887, and was attended by a brilliant military gathering and distinguished civilians.

The following is a brief recapitulation:

A. J. Drexel, President and Chairman of the Executive Committee

Committee on Invitation:

Col. John P. Nicholson, Chairman

Finance Committee:

Capt. W. W. Frazier, Jr., Chairman

Committee of the Grand Army of the Republic:

Col. Maurice F. Fagan, Post No. 2, Chairman

Col. Robert B. Beath, Post No. 5, Secretary

Capt. John Taylor, Post No. 51, Treasurer

Reception Committee:

Col. Theo. E. Wiedersheim, Chairman

Committee on Arrangements:

Col. Robert B. Beath, Chairman

Women's Auxiliary Committee:

Mrs. J. Bellangee Cox (Mary McHenry) President

Mrs. J. Dundas Lippincott, First Vice-President

Mrs. Thomas Hockley, Second Vice-President

Miss Fanny Magee, Third Vice-President

Miss Louise E. Claghorn, Secretary and Treasurer 


\section{ORDER OF EXERCISES}

His Honor, Edwin H. Fitler, Mayor of the City of Philadelphia, presided. Music, First Regiment Band. Invocation and Prayer, the Rt. Rev. Cortlandt Whitehead, D.D., Bishop of Pittsburgh. America, Chorus led by Col. O. C. Bosbyshell. Presentation of the Statue, by the Hon. Benjamin Harris Brewster, and its unveiling by Master George Gordon Meade and Master George Gordon Meade Large, grandsons of General Meade. Reception of the Statue, by the Hon. George H. Boker, President of the Commissioners of Fairmount Park.

Military:

Marshal, Colonel James C. Biddle

Standard Bearers supporting three historic flags:

Headquarters Army of Potomac

Headquarters Fifth Corps

Headquarters Pennsylvania Reserves

First Troop Philadelphia City Cavalry

General E. Burd Grubb, commanding

Survivors Pennsylvania Reserves

Survivors 114th Regiment Pennsylvania Volunteers

Grand Army of the Republic, representatives of 33 posts

First Brigade National Guard of Pennsylvania

Governor James A. Beaver and Staff

Major General John F. Hartranft and Staff

Officers of the Army, Navy and Marine Corps, active and retired

Members of the U. S. Congress and of the Legislature of Pennsylvania

General John Gibbon, U. S. A., delivered the oration, in which the career of General Meade was reviewed in a masterly manner and full credit was given to his great achievement at the field of Gettysburg.

Upwards of 5000 were present.

\section{8}

In the minutes of March 22d occurs the following:

"The Chairman (Thomas Hockley) announced that Messrs. Harrison Bros. \& Co. desired to supply the Association with funds for a Statue of their ancestor, John Harrison, the founder of their establishment."

This matter was referred to the Committee on Works of Art, which was followed on March 29, 1888, by the following action:

"Resolved, That it is inexpedient at the present time for the Association to undertake the formation of a fund for the erection of a statue of the late John Harrison." 
Recently the Association has been informed that by the will of the late Thomas Skelton Harrison a sum approximating fifteen thousand dollars has been bequeathed by him to this Association for the purpose of erecting the statue referred to above, Harrison having been noted as the first manufacturer in this country of sulphuric acid, probably the most important article of chemicals that had been produced up to that time.

On March 29th, the late Ferdinand J. Dreer, then VicePresident and a member of the Board, suggested that the memory of GeneralLa Fayette should be perpetuated in a bronze statue and announced that he would subscribe one hundred dollars to begin the fund. Owing to the many activities of the Association in various directions, this suggestion has not developed, but it is hoped, that, at no distant time, when normal conditions have been resumed, the necessary amount may be obtained and that due recognition may be made of the eminent services that La Fayette rendered to this country in the time of its greatest stress.

At the annual meeting, held March 29th, Mr. Leslie W. Miller offered the following resolution, which was adopted:

"Resolved, That it is the sense of this meeting that the charter of this Association should be so amended as to extend its scope to the whole corporate limits of the City of Philadelphia."

Following this, the City Branch was established, the charter having been duly amended, so as to extend its scope as noted above.

The Indian Group, "Stone Age in America," by John J. Boyle, a commission from the Association, was placed in the West Park near the Children's Public Play Ground.

The Bronze Group, "Lioness carrying to her young a Wild Boar," by August Cain, a commission from the Association, was placed near the foot of Lemon Hill

John Bellangee Cox, ${ }^{*}$ a member of the original Board of Trustees and the first Secretary of the Association, died during this year.

1890

The Equestrian statue of Jeanne d'Arc by Frémiet was unveiled November 15, 1890.

* See page 91. 


\section{ORDER OF EXERCISES}

Invocation by the Rev. Dr. C. Miel. Unveiling by Miss Lucille Rigueur; music by Girard College Band, "La Marseillaise." Address by Samuel Gustine Thompson, in receiving the statue, on behalf of the Commissioners of Fairmount Park; address by M. Louis Vossion, French Consul, on behalf of M. Frémiet, the sculptor. Oration by Professeur Rigueur in French.

The Annual Report, presented December 12th, noted:

"Your Association has been criticised in purchasing so often works of art which exhibit brute force or cruelty.

"While not accepting this criticism as correct in an Art sense, it must be borne in mind that it is not within the province of your Board, nor indeed within its power, to interfere with the conceptions of great artists. The choice must be made from the best works as created. There has not been a single production of genuine merit placed within our reach that has not been purchased as our means allowed. We have contracted for works even when it was necessary to trust to the art-loving public to complete the amount necessary for their acquisition. This trust has never been disappointed."

\section{1}

The first bequest to the Association is recorded in the minutes of November 16, 1891, when announcement was made that eight thousand dollars had been bequeathed by the late Alfred Bamber; this was immediately invested and added materially to the permanent fund.

Henry C. Gibson, * a member of the original Board of Trustees of this Association, died during the year 1891.

\section{2}

On November 22, 1892, J. Sergeant Price was extended the thanks of the Board for his professional services, which were rendered without charge. He continued to serve for many years, up to the time of his death, giving important advice in all matters relating to legal affairs as they occurred. Mr. Price was a life member and at all times evinced a keen interest in the welfare of the Association. His father was a member

* See page 101. 
of the original Fairmount Park Commission and his son is now Vice-President of the Commission and one of the Trustees of this Association.

The most important work accomplished by the Association was announced December 27th, at a meeting held at the office of Drexel \& Company, when Mr. Drexel presided and the officers of the Association were authorized to enter into a contract with Daniel Chester French for the bronze equestrian statue of General U. S. Grant.

\section{3}

In January permission was given to John J. Boyle for the removal of his famous group, "The Stone Age," from the Park to Chicago, to be exhibited at the World's Fair, an exceptional undertaking. It was a high compliment to the sculptor as well as to the Association, that had given the commission.

On March 1st the suggestion was made by Charles $\mathrm{H}$. Howell that perpetual memberships should be created. This was carried out and has added materially to the increase of the permanent fund.

A member of the Board of Trustees, visiting Europe during the spring, called upon Martin Wolff, the noted sculptor, at Berlin, and was much impressed by his statue of Brutus in marble. He was informed that it had been done especially for a patron in Denmark, who had died, and hence it was not practicable to complete the contract; it had been offered to the Imperial German Government, but the Director of Fine Arts had immediately replied that under no circumstances would the representation of a conspirator against authorized government be permitted to occupy any public place in Germany.

On July 7 th a special meeting was called to take action upon the death of the first President of the Association, Anthony J. Drexel, at which John Sartain presided and the following are noted as being present:

Cornelius Weygandt, John T. Morris, Henry K. Fox, Frederick Shelton, Joel J. Baily, Charles H. Howell, Albert G. Hetherington, Charles J. Cohen.

A minute recited the great benefit that had accrued to the Association through Mr. Drexel's presidency and noted his many qualities of the highest citizenship. 
The Bronze group, "Lion and Serpent," by Barye was purchased by the Association; it is a replica of one in the Garden of the Tuileries, Paris, and was reproduced by permission of the French Government. It was placed in Rittenhouse Square, the presentation address made by G. Heide Norris, Esq., representing the Association, and was received by his Honor, Mayor Edwin S. Stuart, for the City on March 2nd.

1895

On the death of Mrs. Richard Smith on May 6th, the provision of the will of her husband, Richard Smith, appropriating five hundred thousand dollars for a memorial arch in memory of the Soldiers and Sailors of the Civil War, 1861-1865, to be erected in West Fairmount Park, under the auspices of the Fairmount Park Art Association, became operative. Soon thereafter a special committee was formed for the purpose of undertaking this important work and after many discussions as to the true meaning of the term, "under the auspices," the Trustees finally accepted the responsibility of selecting the sculptors and approving their work. This committee was composed as follows:

On Monumental Memorial (bequest of Richard Smith). E. Burgess Warren, Chairman

Charles J. Cohen, Secretary

On behalf of the Board of Trustees:

William W. Justice Charles C. Harrison, Ll.D.

On behalf of the Association:

Charles E. Dana

Wescott Bailey

James MacAllister, LL.D.

W. Beaumont Whitney

And the Committee on Works of Art:

Charles M. Burns, Jr.

EdWARd H. Coates

Charles J. Cohen

Charles E. Dana

A. G. Hetherington

John H. Converse

Albert Kelsey

Leslie W. Miller

JOHN T. MORRIS

E. Burgess Warren

Special Sub-Committee to consider the artistic work was composed as follows:

John T. Morris

Edward H. Coates, Chairman

Albert G. Hetherington

L. W. Miller

Charles J. Cohen

Charles E. Dana 
"The Committee has been actively engaged during the current year in the task of selecting sculptors, to whom the bronze statuary on the proposed memorial arch should be assigned. After several months' careful examination and deliberation, the Special Sub-Committee of Five, entrusted with the detailed work, made an exhaustive report, with the list of the names of their choosing, to the General Committee, by which it was unanimously approved. Subsequently the report was placed before the Board of Trustees and was unanimously accepted by them. A complete report was then submitted to John B. Gest, Esq., Trustee, and James H. Windrim, Esq., Architect, who have approved the findings as submitted. The work is now progressing rapidly toward an early completion.

"It should be borne in mind that the Fairmount Park Art Association and the Committees appointed have no authority or supervision as to the architectural design and construction of the memorial monument and gateway, which are specifically provided for under the will of Richard Smith.

"This work covered upwards of fifteen years, during all of which time the Committee had very many meetings, including visits out of town, where sculptors resided, to make careful inspection of the models and the work as it progressed. The completed memorial has attracted wide and favorable comment."

At the 24th Annual Meeting, December 28, 1895, an address, "Historic Mansions in Fairmount Park," by Charles S. Keyser was delivered and attracted wide attention, it being the first authentic account of the early history attached to these structures.

\section{6}

On the evening of May 30th (Memorial Day), the Garfield Monument was unveiled. The ceremonies were unique and imposing, comprising a river fête with an accompanying illuminated pageant on the river Schuylkill. This was organized by a special committee, of which Miss Charlotte Pendelton was Chairman, the Committee consisting of representative men and women, who lent their presence on the occasion.

The unveiling of the memorial was by Harry A. Garfield, 
son of the late President; the address by the Hon. George F. Edmunds, Ex-Senator of the United States; music by a stringed orchestra, accompanied by the United Singers (300 voices). The surrounding woods were gorgeously illuminated.

This assemblage was also considered to mark the twentyfifth anniversary of the founding of the Fairmount Park Art Association.

\section{7}

At the Annual Meeting, May 26th, Mr. John Sartain gave an address from his "Unpublished Memoirs"; it was replete with interest, especially to Philadelphians, treating as it did sections of the City that have undergone manifold changes.

In June the colossal bronze equestrian group, "Lion Fighter," by Professor Albert Wolff, was placed on a natural jutting rock, East River Drive, below Girard Avenue Bridge.

The natural rock, instead of a pedestal, proved an innovation; it gives to the work a fitness and grandeur that could be obtained in no other way.

Deaths were announced of George B. Roberts, VicePresident, and of J. Sergeant Price, Counsel of the Association, and the Board placed upon its minutes a fitting expression of its regard and esteem and appreciation of the services of its late officers.

\section{8}

On December 19th, Henry K. Fox, the only member (now a Trustee) surviving of the original Board, who had served as Treasurer for many years, was obliged to withdraw from the office, since the duties had become onerous owing to the increase of the funds and activities of the Association. An appropriate minute was adopted and printed in the Annual Report.

\section{9}

In 1899, the Grant Monument was unveiled. The figure is by Daniel Chester French, the horse is by Edward C. Potter, and the pedestal was designed by Frank Miles Day \& Bro.

Following the death of General Ulysses S. Grant in July, 1885 , a movement was set on foot for the purpose of collecting a suitable fund with which to erect a bronze equestrian statue to his memory. By proper investment of the amount ob- 
tained and an accretion of interest, together with the liberal contribution made by the City Councils of Philadelphia, the entire cost of the statue and pedestal had been defrayed. Grant Day, April 27, 1899, was decided upon. The day opened cloudy and remained overcast until noon, when the sun appeared, and the ceremonies were of an impressive and successful character. Stands were erected adjoining the statue and were occupied by the invited guests, as follows:

His Excellency, Hon. William McKinley, President of the United States

Mrs. William McKinley, wife of the President

Mrs. Ulysses S. Grant, widow of General Grant

Hon. Lyman J. Gage, Secretary of the Treasury

Mrs. Gage

Hon. John Davis Long, Secretary of the Navy

Mrs. Long

Hon. Ethan Allen Hitchcock, Secretary of the Interior

Hon. John William Griggs, Attorney-General

Mrs. Griggs

Brigadier-General Frederick D. Grant, U. S. V. (Son of General U. S. Grant)

Mrs. Grant

Captain Algernon Sartoris, U. S. V. (Grandson of General U. S. Grant)

Miss Rosemary Sartoris (Granddaughter of General U. S. Grant)

Lieutenant Alexander Sharp, U. S. N. (Nephew of General U. S. Grant)

Dr. Rixey, Physician of the President

Mr. George B. Cortelyou, Acting Private Secretary (afterward Postmaster-General)

Major-General Nelson A. Miles, Commanding U. S. Army

Captain J. B. Coghlan, U. S. S. "Raleigh"

Lieutenant-Commander T. S. Phelps, U. S. S. "Raleigh"

Hon. William A. Stone, Governor of the Commonwealth, Commander-in-Chief, National Guard of Pennsylvania

The Committees with their Chairmen were as follows:

General Committee on the Unveiling

John H. Converse (President), Chairman

Finance Committee

Joel J. Baily, Chairman

Committee on Invitation

Col. John P. Nicholson, Chairman

Reception Committee

JoHN T. MORris, Chairman 
Women's Reception Committee

Mrs. Charles Custis Harrison, Chairman

Committee on Military Display

Col. Theodore E. Wiedersheim, Chairman

Committee on Ceremonies

Col. Charles H. Howell, Chairman

Committee on Stands

Charles J. Cohen, Chairman and Secretary to the General Committee

Committee on Publication

Joel J. Baily, Chairman

Special Committee to wait upon the President and his Cabinet

John H. Converse (President)

Charles C. Harrison

Frank THOMSON

JOHN T. MORris

There were twelve additional committees appointed to wait upon the distinguished guests.

The State of Pennsylvania and the City of Philadelphia were represented by special delegations from their respective legislative bodies and also by the Governor of Pennsylvania and the Mayor of Philadelphia.

\section{PROGRAMME OF THE UNVEILING CEREMONIES ON THURSDAY, APRIL 27, 1899 "GRANT DAY"}

\section{THE 77th ANNIVERSARY OF HIS BIRTH}

\section{Mayor Ashbridge, Presiding}

Invocation by Rt. Rev. O. W. Whitaker, D.D., Bishop of Pennsylvania Presentation of the Statue by President John H. Converse

Unveiling by Miss Rosemary Sartoris, Granddaughter of General U. S. Grant

General's artillery salute by Battery D, National Guard of Pennsylvania Reception of the Statue by Hon. A. Loudon Snowden on behalf of the Commissioners of Fairmount Park

Introduction of the Sculptors, Daniel Chester French and Edward C. Potter

Review of the Troops by the President of the United States:

Chief Marshal-Major General George R. Snowden, with Staff 
First Division-United States Naval Forces, Captain J. B. Coghlan, U. S. N., Commanding. (Captain Coghlan with the "Raleigh" was in the engagement at Manila and fired the historic shot on that memorable occasion.)

Battalion of Marines and Seamen, Pennsylvania State Troops, Grand Army of the Republic, consisting of over a thousand old soldiers who had served under General U. S. Grant

Upwards of 7000 were in the military parade.

At the conclusion of the unveiling ceremonies Mrs. McKinley, Mrs. Grant and the other guests were entertained later at dinner by Mrs. Joshua Lippincott at her residence (the Dundas Mansion), Broad and Walnut Streets.

President Converse entertained at dinner at the Union League President McKinley, the members of his party and distinguished guests and the Trustees and Committees of the Fairmount Park Art Association.

At 8 o'clock P. M., President McKinley, accompanied by Mr. Converse and his guests, was escorted to the American Academy of Music, which building was filled to its utmost capacity, where the President was received with an enthusiastic ovation.

A masterly oration was delivered by Hampton L. Carson, Esq., followed by a short address by the President.

On the day following, President McKinley, escorted by a Committee of the Fairmount Park Art Association, visited the U. S. S. Raleigh, lying in the Delaware River, was received with full honors and made an address to the officers and men.

(The above has been taken from a complete illustrated report No. 33, published by the Association at the time, copies of which may be had by those interested upon application to the Secretary.)

At the meeting of the Board of Trustees, held September 21, 1899, Mr. James W. Paul, Jr., stated that a friend and public spirited citizen had offered to contribute to the Fairmount Park Art Association as trustee the sum of Five thousand dollars towards a fund for erecting a statue to the late Captain John Ericsson, the inventor and builder of the United States iron-clad Monitor, which so successfully fought the Confederate ram Merrimac, March 9, 1862, during the war for the Union.

Following this, other subscriptions were obtained, the Association agreeing to contribute liberally, and the Commission would have been carried out, had it not been for the 
World War, which interfered greatly with the development of the East Bank of the Schuylkill in the vicinity of the old Water Works, for which development a commission had been given to Prof. Paul P. Cret, who, however, was engaged in the war in France and has only recently returned to this country.

In November, Charles H. Howell was obliged to withdraw from the Secretaryship and an appropriate minute thereon was adopted.

At the Annual Meeting, October 31, 1899, it was stated that two fine antique bronze cannon and a mortar from the fortifications of Havana, which were cast at Barcelona and Seville, Spain, in 1731 and 1734, had been acquired and had been placed temporarily on Belmont Drive. Later they were removed to the front of Memorial Hall and placed on special carriages constructed from designs made by Charles E. Dana, Vice-President of the Association.

The three pieces, from fortifications in $\mathrm{Cuba}$, are ornamented with decorations, including the royal arms of Spain as employed by Philip V and his Queen, Elizabeth.

\section{0}

At the Annual Meeting, on December 19th, Vice-President Charles E. Dana gave an illustrated address, entitled "Arms, Armor and Display in the Middle Ages."

Mr. Dana was a past master in this subject and the address was cordially received and attracted wide attention upon its publication in the 29th Annual Report.

On December 7 th, the finance committee had been discussing the character of investment for available funds and finally obtained an opinion from the Hon. James M. Beck, their counsel, which supported the legal construction of the resolution adopted by the Board, so that the method of investment was endorsed as to the purchase of bonds of the United States of America, of the State of Pennsylvania or of the City of Philadelphia, as well as investment in first mortgages on improved real estate in the city of Philadelphia. Of recent years however mortgages have not been favored and by recent action it has been decided to collect those now held, as they fall due, making investment in government securities, as noted above, the permanent practice of the Society. 
Elwell's group of "Charles Dickens and Little Nell" was erected in Clarence H. Clark Park in West Philadelphia.

\section{2}

On January 16th, the Board received from the Trades League of Philadelphia (now Philadelphia Chamber of Commerce) a sum approximating Two thousand dollars, that had been raised under the title of the "Childs-Drexel memorial fund"; this has been suitably invested and when opportunity offers the idea of the donors will be carried out.

On February 7th, the following Resolution was adopted:

"Resolved, This Association will accept the trust to erect in Fairmount Park a memorial to a distinguished soldier and statesman to cost not less than ten thousand dollars, as proposed by Mr. Morris in his letter presented at this meeting, provided the design as a whole, including the inscription, shall first be approved by the Commissioners of Fairmount Park," and it was further

"Resolved, That this Board expresses through Mr. Morris to the generous and public spirited person referred to in his letter its appreciation of the proposal to entrust to this Association the erection of such a memorial and its gratification at this acknowledgment of the purpose and principles of the Association."

On March 11th, the firm of Burnham, Williams \& Co., Baldwin Locomotive Works, wrote as follows:

"This firm is ready to contribute a sufficient sum for the erection of a statue of Matthias W. Baldwin and would be glad to have the Fairmount Park Art Association take charge of the execution of the work. It has seemed to us that a proper site would be the east side of Broad Street at the end of the grass plot in the middle of Spring Garden Street."

This trust was accepted, the commission after due consideration being awarded to Herbert Adams, and the statue was completed and dedicated on June 2, 1906, his Honor, Mayor Weaver, officiating on the interesting occasion, which was made notable by the presence of George Burnham, Sr., then in his 90th year, who had been associated with Matthias W. Baldwin for very many years.

On October 3d, the following was adopted:

"The Board of Trustees, Fairmount Park Art Association, at their first meeting held since adjourning for the summer, must perform a melancholy duty in noting the death of Col. Charles H. Howell, late President of the Association, on June 18, 1902. 
"More than thirty years ago, when American sculpture was an art in its infancy, Col. Howell, then a very young man, animated by a desire to add to the attractiveness of his native city, conceived the idea of the formation of a society of ladies and gentlemen, who by annual contributions and by careful and earnest work might finally succeed in so desirable a consummation. Enlisting the interest and services of a number of art loving citizens, there was formed the Fairmount Park Art Association. As a director from its inception and serving as Secretary and finally as President, he gave the very best years of his active life to the enlargement and development of this work. He had the satisfaction of recognizing the position that the Association had gained not only in our own city and state but in the country generally and it must have been no small gratification to him to read in the journals of the day favorable comments on the work of the Society in its various directions.

"It must not be supposed that these results were accomplished without great energy and self-sacrifice. During many years there were periods of uncertainty depressing in the extreme and to a man less persistent and less conscious of the duty of citizenship these would have been overwhelming and would have finally resulted in the possible disbandment of the Association; but through dark days and bright ones the same energy and activity always remained with Col. Howell and always served him in good stead in the trials that beset the Association during its early existence. The members of the Board feel most keenly the severance of those close personal relations, that existed for so long between their late President and themselves, and feel that the highest testimony of his worth by them may be best expressed through an active interest in the development of the ideas and purposes of this Association, for whose welfare he gave so many years of his life and in whose successful growth his greatest happiness lay. 'He mourns the dead who lives as they desire."

\section{3}

On November 13 th, action was taken on the suggestion that a box of documents be placed in the foundations of all statues erected in future by the Association, so that the generations in the distant future might have current history available; therefore, when the statue of the "Medicine Man" was erected, a metal box hermetically sealed was placed in the foundation, the contents being the newspapers and American coins of the day with printed matter representative of local history.

The minutes are replete with records of donations from members of the Board and friends of many photographs of statuary and buildings both in this country and in Europe; these have been arranged in a cabinet belonging to the Association and indexed and may be referred to at any time by those interested. 
The equestrian statue, "The Medicine Man," in bronze, by Cyrus E. Dallin, was purchased by the Association and erected in the East Park at the head of Strawberry Hill, near the Dauphin Street entrance, on a pedestal of red Westerly granite.

It was unveiled on December 10th and was formally presented to the City of Philadelphia and the Commissioners of Fairmount Park at the Thirty-second Annual Meeting of this Association on the evening of the same day.

At the Annual Meeting, December 10th, attention was called by the Chairman to the design for a seal for the Association, printed on the programme of the meeting, and on motion of Mr. William W. Justice, duly seconded, the design was unanimously adopted as the seal of the Association.

\section{4}

On February 12th, it was reported that the new seal of the Association, admirably designed by Charles E. Dana, Vice-President of the Association, had been adopted.

On November 11th, notation was made of the generous bequest by the late President, Charles H. Howell, to the Association.

At the Annual Meeting, December 16th, Henry K. Fox, Esq., seconded by Col. M. Richards Muckle, offered the following:

"Whereas The Fairmount Park Art Association at its Annual Meeting held on the 24th of March, 1886, adopted the following preamble and resolutions:

Whereas The Board of Trustees on the sixteenth day of December, A. D., 1874, established the Permanent Fund, by resolving in the words following:

1. That the Treasurer set apart Three thousand dollars of the funds of the Association as a foundation for a permanent fund.

2. That the Treasurer shall hereafter add to the said Permanent Fund all the sums of money hereafter received from life membership dues, together with ten per centum of all dues received from annual members, and all special contributions, bequests, etc., except such as may hereafter be otherwise disposed of.

And Whereas It is desirable that the said Permanent Fund shall be by this Association declared inviolable:

Therefore be it REsolved, That the principal of the said Permanent Fund shall never be expended or reduced for any purpose whatever.

REsolved, That the interest of the said Permanent Fund shall not be expended for any purpose whatever and that it shall be accumulated and added to the fund and be made part of the principal hereof, until this Association shall order it otherwise. 
And Whereas It appears by the Treasurer's report presented at this Annual Meeting, that the Permanent Fund has reached a sum in excess of One hundred thousand dollars;

And Whereas It is deemed advisable that the Permanent Fund shall be kept intact, but that the income arising from the Permanent Fund shall be expended for the purchase of works of art for the adornment of Fairmount Park and for such other purposes under the constitution of the Association, as the Board may approve; Now therefore be it

Resolved By this Association, that the principal of the Permanent Fund shall never be expended for any purpose whatever, but that all sums of money hereafter received from life membership dues, ten per centum of all dues received from annual members and all special contributions, bequests, etc., unless otherwise specified, shall be added to the principal of the said Permanent Fund and that the same shall be kept inviolable. And be it further

Resolved By this Association, that the Board of Trustees of the Fairmount Park Art Association be authorized to expend from time to time such sum or sums, that may hereafter accrue as interest or profit on the Permanent Fund of the Park Branch of this Association, for the purchase of works of art for the adornment of Fairmount Park or for such other purposes under the constitution of the Association, as the Board may approve."

In support of the resolution Mr. Fox said that it was offered with the feeling that its adoption would assure the permanency of the Associaton, and he believed that it would greatly strengthen it for service in the broader and higher field of usefulness in the community, to which, as noted in the report which had just been read, the Association was unmistakably called.

\section{5}

The Sun-Dial and Marble Pedestal, presented to the City of Philadelphia through this Association by a member, who desired the gift to remain anonymous, was erected in the centre of the Sunken Garden in front of Horticultural Hall, in the West Park, in May.

The dial is of bronze, accurately calculated for the exact spot, in which it is placed, and shows the variations for each month of the year and the time at 12 o'clock in twelve principal cities of the world.

The pedestal is the work of Alexander Stirling Calder, and the design includes the twelve signs of the zodiac and four supporting female figures, emblematic of the four seasons.

\section{6}

On March 9th, the following resolution was adopted: "Whereas The Fairmount Park Art Association was founded in the 
year 1871, at which time Henry K. Fox, Esq., was one of the original members, as also one of those signing articles of incorporation, continuing to be a member of the Board of Trustees to the present time, devoting to the Association his best efforts toward the development of its scope and usefulness, therefore be it

Resolved, That on this approaching 35 th Anniversary of its foundation the Board of Trustees of the Fairmount Park Art Association extends to Mr. Fox a message of congratulation, to which is added the earnest hope that he may always continue his interest in the work with which he has been so long identified, and be it further

Resolved, By virtue of the privilege granted in the by-laws and in recognition of his continuous service to the Association, that the name of Henry K. Fox be added to the list of honorary members of the Fairmount Park Art Association."

On April 27th, the Committee appointed to revise the charter and by-laws made an elaborate report, the main feature being the extension of the work of the Association to cover the City of Philadelphia as well as the Park, which was formally adopted shortly thereafter.

At the Annual Meeting, December 19th, the principal address of the evening was delivered by Frederick Crowninshield, Esq., President of the Fine Arts Federation of New York, who took for his subject the place and function of a Municipal Art Gallery. The Hon. Samuel Gustine Thompson also spoke in the interest of the proposal to erect such a gallery in this city and the following representatives of art organizations of the city also spoke briefly to the same effect:

Mr. John H. Converse, for the Pennsylvania Academy of the Fine Arts Prof. Herbert Everett, for the University of Pennsylvania

Mr. Leslie W. Miller, for the Pennsylvania Museum and School of Industrial Art

James MacAlister, LL.D., for the Drexel Institute

Mr. Elliott Daingerfield, for the School of Design for Women

Mr. James P. Jamieson, for the Philadelphia Chapter, American Institute of Architects

Mr. Thomas K. Kellogg, for the T-Square Club

Miss Florence W. Fulton, for the Plastic Club

Mr. Ludwig E. Faber, for the Philadelphia Sketch Club

On motion of James MacAlister, LL.D., it was resolved that the Board of Trustees be instructed to prepare a memorial to be sent to the Mayor and Councils of the City in the interest of the proposed Municipal Art Gallery.

\section{7}

On January 11th, a committee was appointed entitled "The Committee on a Municipal Art Gallery," whose province 
it was to urge upon the city government and upon the public the importance of the movement for a public art gallery worthy of the city. This was the beginning of the agitation, which will soon result in the realization of the ambitious plans for a structure, that will be a great credit to Philadelphia and will attract a world-wide attention, and for which future generations will express gratitude to their predecessors, who had the courage and energy to promote this work.

On April 26th, the Board appointed a commission, consisting of Mr. C. C. Zantzinger, Prof. Paul P. Cret, and Mr. Horace Trumbauer, to plan the development of the entrance of the proposed Parkway into Fairmount Park.

The Commission made a careful study, presented its record, which was published, and from this inception was developed the splendid plans now perfected under the care of Mons. Gréber, of Paris, the foremost authority in decorative landscape planning, so that at no distant date Philadelphia will have a Parkway of which it may well be proud. (For full description see page 244.)

\section{8}

On November 13th, upon the death of the Association's Treasurer, Mr. Paul, Mr. Justice was elected Treasurer and the Pennsylvania Company for Insurances on Lives and Granting Annuities was appointed fiscal agent and all books and papers, as well as the securities belonging to the Association, were transferred to that company, which makes but a nominal charge for their care; its annual reports are models of clearness, and it renders services that could not possibly be given by any but a banking institution.

On June 20th, the bronze statue, "Cow-boy," by Frederick Remmington, was erected on the East River Drive near Girard Avenue Bridge on a natural rock; the statue is unconventional and striking and it is carried out with a bold and confident technique that compels the heartiest admiration.

\section{9}

On January 8th, the Board adopted the following resolution: "That the Board of Trustees of the Fairmount Park Art Association desires to express in the name of the entire membership of this Association its sincere appreciation of a generous gift to the city by Joseph Wharton, Esq., of a tract of land in North Philadelphia suitable for a public park. We 
regard this action of our distinguished fellow citizen as representative in the fullest sense of the best influences at work today for the civic development and of the best traditions of public spirited citizenship in Philadelphia."

Amended By-laws, prepared by a special committee, were submitted at the Annual Meeting on January 27 th and were unanimously adopted.

On February 19th, the Japanese Temple Gate, that had been erected in the West Park as a gift from John H. Converse and Samuel M. Vauclain, was most attractively improved in its setting by the addition of a garden as an approach, constructed by Japanese at that time in the United States, who were employed by the donors, John T. Morris and John H. Converse. This improvement was presented by them to the Park Commission through this Association. (See page 168.)

\section{1}

On January 13 th, attention was called to the gift of land near Fern Rock for park purposes by the heirs of the late Joseph Wharton, to be known as Fisher Park, in execution of Mr. Wharton's offer made just before his death, and the Secretary was instructed to send a letter to the donors, Mrs. J. Bertram Lippincott, Mrs. Harrison S. Morris and Miss Mary H. Wharton, expressing the Board's appreciation of this gift to the city.

On February 10th, Mr. Roland L. Taylor, a member of the Board, was named as Chairman of the Committee appointed by the Pennsylvania Bankers' Association to erect a memorial to Robert Morris, the financier of the Revolution, whose ability at that critical period brought the country through its financial crisis with marked success.

It later developed that the State of Pennsylvania had appointed a Commission and made an appropriation of Twentyone thousand dollars for the same purpose. After some negotiation Mr. Taylor's committee from the Association as well as from the Bankers' organization and the State representatives came together in a final adjustment and agreement to erect the statue on the steps of the United States Custom House on Chestnut Street between Fourth and Fifth Streets. The commission has been placed and will be carried out at an early date.

On November 8th, announcement was made that the 
monumental memorial bequest of Richard Smith, begun in 1897, had been completed and the following minute was made: "The Board of Trustees of the Fairmount Park Art Association has received from its committee on monumental memorial bequest of Richard Smith its report on the action taken at the meeting held June 4, 1912, and at this, the first stated meeting of this Board held since the date above noted, desires to extend to William P. Gest, Esq., Vice-President of the Fidelity Trust Company, trustee, its very great appreciation of his message of good will and courtesy and to give assurance that this Board jointly with its committee has considered it a great privilege and an honor to have been entrusted with the artistic interests associated with the various commissions required for the completion of the memorial. Whilst much thought and energy were necessarily devoted through the series of years beginning with 1897 from the first invitation asking this Board of Trustees to take under its auspices this artistic work, which has been followed with conscientious care, the reward of the committee comes in this cordial appreciation and in the recognition of the admirable work in a completed memorial, which will be an additional mark of attraction in our city and will be notable both because of the cause that it serves to commemorate and as a fitting monument to the generous donor, whose wishes have been so faithfully carried out by his executor and trustees."

The Annual Report, presented in January, 1911, notes:

"Efficient service of a kind suggested by the enlarged purposes of its amended charter has been rendered during the year in the steps that have been taken to protect that birthplace of American liberty, Carpenters' Hall. Through the active generous interest of two members of your Board, each of whom contributed liberally, a fund was raised by special subscriptions from the Carpenters' Company, the Pennsylvania Society of Colonial Dames of America and a number of public spirited citizens and associations, sufficient to purchase an adjoining property and remove the building which occupied it, whose continuance would have been a perpetual menace to the safety of this historic building."

1912

At the Annual Meeting on January 15th, Col. William C. Church of New York gave an address on John Ericsson, 
the creator of the modern navy, illustrated with scenes from the life of Ericsson, showing some of the enterprises in which he was engaged. The address was listened to by a distinguished audience of ladies and gentlemen, members of the Association and their guests, as also by a delegation of enlisted men headed by prominent officers from the United States Navy Yard at League Island.

The Annual Report, presented at this meeting, notes:

"It is a source of much satisfaction to report that the Municipal Art Jury, whose appointment was authorized by an act of the State Legislature in 1907, was appointed by His Honor, Mayor Reyburn, November 9, 1911. The need of such a body has long been urged by your Board and it is believed that its creation marks a most important stage in the development of the plans for a more beautiful city, which have come to occupy, in one form or another, so large a share of public attention.

The act creating the Art jury, provides:

"Hereafter no work of art shall become the property of a city of the first class by purchase, gift or otherwise, unless such work of art or design for the same and the proposed location of such work of art shall first have been submitted to and approved by the art jury of said city; nor shall any work of art, until so approved, be erected or placed in or upon or allowed to extend over any building, highway, stream, lake, square, park or other public place belonging to or under the control of said city. The jury may, when it deems proper, also require a complete model of the proposed work of art to be submitted to it before taking final action thereon. The term 'work of art,' as used in this act, shall include all paintings, mural decorations, inscriptions, stained glass, statues, reliefs, or other sculptures, monuments, fountains, arches or other structures, intended for ornament or commemoration. No existing work of art in the possession of the city shall be removed, relocated or altered in any way without the approval of the jury."

The jury is also required to "make from time to time such recommendations for improvements to the city as it may deem advisable." It is apparent, therefore, that an authoritative and responsible agency has been provided to exercise initiative, as well as oversight, in connection with a large and varied range of effort, on whose direction into proper 
and profitable channels the art interests of the Philadelphia of the future will so largely depend.

1913

The report at the Annual Meeting in 1913 notes:

"In connection with the improvement in the appearance of the bridges, that has been brought about by the censorship exerted by the Art Jury, it is a matter of sincere congratulation that the usefulness of this body, for the creation of which this Association is largely responsible, is recognized and welcomed in increasing measure with each added year of its existence and the service which it renders to the bureaus, corporations and firms, whose work it is its duty to supervise, is, in the vast majority of cases, accepted in a spirit of appreciation for helpful suggestions rather than of impatience at requirements exacted. That the entrance to Lansdowne Drive will be under two spacious elliptical arches, instead of through four narrow tunnels; that such viaducts as those which carry the railroads across Girard Avenue, Broad Street, Spring Garden Street and many other thoroughfares, are dignified and handsome structures, instead of the unsightly rows of iron girders, which would have been accepted by an unquestioning public as an inevitable infliction a few years ago; that crude schemes for new parks and boulevards have been restudied and enormously improved before being carried out; and that even the long neglected Delaware water front has begun to receive the kind of treatment, to which, as the central feature of commercial activity in one of the great ports of the world, it is justly entitled, is due to the intelligent guidance and the tasteful supervision of the Art Jury."

The Report for 1913 further notes:

"By the will of Mrs. Ellen Phillips Samuel, a member of this Association, who was deeply interested in its work and desirous of extending its influence and who died October 1, 1913, the Association becomes the legatee to her entire residuary estate, which it is conservatively estimated, will amount to upward of Seven hundred and sixty-five thousand dollars (\$765,000). On the death of her husband, J. Bunford Samuel, Esq., the bequest will become available for the following objects: 'According to the Official Map issued by the Park Commission there is a space of two thousand (2000) feet commencing from the Beacon Light or last boathouse to the Girard Avenue 
Bridge. On the edge of this ground, bordered by the Schuylkill River, is a stone bulkhead. On top of this embankment it is my will to have erected at distances of one hundred (100) feet apart, on high granite pedestals of uniform shape and size, statuary emblematical of the History of America, ranging in time from the earliest settlers of America to the present era, arranged in chronological order, the earliest period at the south end and going on to the present time at the north end; and, when all the statues are in place, the income to be spent in buying statuary and fountains to decorate the Park."

This munificent bequest, the largest probably that has ever been made for a similar purpose in America, is moreover to be augmented by the generosity of Mr. Samuel, who has expressed a desire to supplement the provisions of the will by himself beginning the work of erecting the memorial, which will therefore receive the benefit not only of his generous addition to the funds available for this purpose, with the corresponding saving of time, but of his advice and counsel in connection with the work of determining the character of the memorial and of beginning the actual work of construction.

At the meeting of the Board, held on November 14th, the following resolutions were adopted:

"Resolved, That the Board of Trustees of the Fairmount Park Art Association has received with much satisfaction notice of the munificent bequest of Mrs. J. Bunford Samuel (Ellen Phillips Samuel), which will provide funds for a comprehensive and dignified treatment of a noble theme-the history of America, symbolized in a system of statuary in Fairmount Park-and which will ensure the continuance for all time on a generous scale of the influence of the Association in promoting the aims for which it exists.

"RESOLVED, That the Board of Trustees gratefully accepts the bequest of Mrs. Samuel and will carry out, to the best of its ability, the wishes of the testatrix."

\section{5}

The Committee, appointed in January to consider plans for the Ellen Phillips Samuel Memorial, having considered this important undertaking, recommended the engagement of Messrs. Edgar V. Seeler, architect, and Charles Grafly, sculptor, to prepare designs for presentation. Upon approval of the recommendation by the Board, this was carried out and the plans with a relief model were shown at the Annual Meeting in January, 1916. 
The Annual Report for this year notes:

“Manship's Fountain Statue, 'The Duck-Girl,' which had remained on exhibition at the Pennsylvania Academy of the Fine Arts since its acquisition by this Association in 1914, was exhibited at the 'Philadelphia To-day and To-morrow Civic Exposition' in June and at the close of that exposition it was delivered to the Commissioners of Fairmount Park for erection in 'Cloverly,' Germantown, the statue itself, as well as plans for a suitable setting, which had been prepared for the Association by Mr. Edgar V. Seeler, having been accepted by the Commissioners, May 10, 1916.

"An exhibit of nineteen large photographs of the more important art works erected by this Association was arranged at the 'Philadelphia To-day and To-morrow Civic Exposition,' where it attracted much favorable notice and bore eloquent testimony to the service rendered to the city by this Association during the forty-five years that it has been in existence. At the close of the exposition the collection, suitably framed and inscribed, was, at the request of the Board of Trustees of the Free Library of Philadelphia, placed in the Library building for permanent exhibition."

The three hundredth anniversary of Shakespeare's death, May 12, 1916, which was made the occasion of very general commemorative observance throughout the English-speaking world, called renewed attention to the fact that Philadelphia is almost alone among the great cities of the world, which might most confidently be expected to possess a memorial to Shakespeare, in being without such a memorial, and at its regular meeting, held March 10th, the Board adopted a resolution, expressing its wish to co-operate with other agencies interested in the erection of such a memorial, and appointed a special committee to carry this resolution into effect. At the next meeting, April 14th, on the recommendation of this committee the Board adopted the following resolutions:

"Resolved, That the Fairmount Park Art Association appropriate the sum of $\$ 10,000$ out of the General Fund (Park Branch) toward the cost of the erection in Philadelphia under the auspices of the Association, in conjunction with the General Committee on the Shakespeare Tercentenary Celebration, of a permanent memorial to Shakespeare, embodying a suitable recognition of the work of the late Dr. Horace Howard Furness and the Shakespearean traditions of Philadelphia, upon condition that an equal sum of $\$ 10,000$ is secured by general subscription within three months. 
Resolved, That your Committee be authorized to co-operate with a committee, to be appointed by the General Committee on the Celebration, in collecting subscriptions for the purpose and, upon the full amount mentioned being secured, to report to the Board their recommendations as to a site and the best method of procuring a suitable design for the Memorial."

In pursuance of this action an appeal was issued on May 1 st, in the form of a personal letter from Hon. James M. Beck, who has from the first been earnestly active in advocating the erection of a memorial to Shakespeare along the lines and in the spirit expressed by the foregoing resolutions; which letter was supplemented by Mr. Beck in an address, which he delivered at the Shakespeare Festival in the Academy of Music on May 12th. The result of this appeal was so prompt and re-assuring, that at a special meeting, called for the purpose on June 9th, the Board assumed the responsibility of making up any shortage that might appear after all available subscriptions toward the $\$ 20,000$ for the memorial had been secured. At the next meeting of the Board, on November 10th, the Secretary was able to report that subscriptions amounting to $\$ 8,170$ had been received, which amount was, within a few days thereafter, all paid in and added to the Association's fund available for the memorial.

As appears from the foregoing statement, the development of the idea, which the memorial is to represent, and the determination of the character, which any sculptural or architectural construction should assume, are matters regarding which the Association desires the co-operation of the Shakespeare Tercentenary Committee, a special committee of which has been appointed for this purpose. The form which the memorial should assume and its definite location are subjects, which are at this moment receiving earnest consideration at the hands of the joint committee.

The nucleus of a fund to provide for a memorial to the flying men of Pennsylvania, who fell in the war, has been created by a gift for this purpose, which was made to the Association in September by the Aero Club of Pennsylvania. The letter from the Club announcing this action is as follows:

"Aero Club of Pennsylvania.

Fairmount Park Art Association, September 29, I9I7.

Mr. Leslie W. Miller, Secretary, Philadelphia.

My dear Mr. Miller:

At the last meeting of the Aero Club of Pennsylvania, held 68 
Friday evening, September 21st, the following motion was passed unanimously-That the Aero Club of Pennsylvania will start a fund for a 'Monumental Memorial' to the flying men of Pennsylvania, who fell in the 'Great War for Human Liberty.' That the Trustees of this fund shall be the Fairmount Park Art Association and that said Association shall have full power to determine the kind and style of memorial and the time of its dedication and its location, either in the city of Philadelphia or Fairmount Park

The Aero Club of Pennsylvania, having a large part of its membership in the service of the Flying Arm of the Navy and Army and Marine Corps, as well as Foreign Esquadrilles, encloses herewith a check to the order of the Fairmount Park Art Association for $\$ 100$ to start this fund.

\section{Yours very truly, Joseph A. Steinmetz, President."}

At the regular monthly meeting of the Board, held on November 9th, this offer was accepted by the adoption of the following resolutions:

"Resolved, That the Board of Trustees of the Fairmount Park Art Association desires to convey to the Aero Club of Pennsylvania its appreciation of the patriotic sentiment shown in the establishment of a fund for the erection of a Monumental memorial to the flying men of Pennsylvania, who fell in the great war for human liberty, and be it further

"Resolved, On behalf of this Association, that the Board of Trustees accepts the Trusteeship of this fund, in accordance with the request of the Aero Club of Pennsylvania, with appreciation of the honor, which that request implies, and pledges its cordial co-operation in this enterprise."

\section{8}

At the Annual Meeting, held on January 30, 1918, the following resolution, which was offered by Mr. Charles L. Borie, Jr., was unanimously adopted:

"Whereas The Fairmount Park Art Association presented at its 36th Annual Meeting, held December 12, 1907, 'A Report of the Commission employed by them to study the Entrance of the Philadelphia Parkway into Fairmount Park,' devoted that meeting to a full discussion of the subject and adequately published the result in illustrated pamphlet form;

Resolved, That this Association request the Trustees to publish, in suitable form, the result of the studies made for the Fairmount Park Commission by Mr. Jacques Gréber, embodying the development of this project, inaugurated by this Association."

A recess was then taken, during which $\mathrm{Mr}$. Joseph A. Steinmetz, President of the Aero Club of Pennsylvania, delivered an illustrated address on "The Aeroplane in War." 
At the close of the address by Mr. Steinmetz, the meeting was reconvened and was addressed by Mr. Joseph Widener on the nature and extent of the work that had recently been done in developing the studies for the Parkway, the river embankments and city squares, with their connecting tree-lined roadways, which were made and published under the auspices of this Association in 1907. This more recent work, which embraced an exhaustive study in detail of the landscape architecture of the whole comprehensive scheme, as well as suggestions for the architectural development of the Parkway, had been done for the Commissioners of Fairmount Park by the distinguished landscape architect, Mr. Jacques Gréber, whose designs were publicly exhibited for the first time at this meeting.

1919

At the Annual Meeting, held on January 16th, Albert Kelsey, the distinguished architect, gave an admirable address on "Memorials," illustrated with views of celebrated structures, that had been erected to commemorate important events, and expressed the hope that America would use judgment and discrimination in the selection of designs for honoring the heroes of the late Great War in Europe.

At the same meeting the following resolution, which was offered by Mr. Andrew Wright Crawford, was unanimously adopted:

"Whereas The Fairmount Park Art Association was one of the originators of the movement, that resulted in the formation of the Art Jury as one of the Departments of the City of Philadelphia; and thereafter the Department of the Art Commission of the City of Pittsburgh was also created and a similar department was authorized for the City of Scranton; and

WHEREAS In Massachusetts there is, in addition to the Art Commission of the City of Boston, the Massachusetts State Art Commission and in New York State a State Art Commission is under consideration, to be in addition to the Art Commissions of the cities of New York and Rochester; and

WHEREAS The deluge of war memorials threatens to reproduce some of the horrors of the Civil War in the form of cemetery designs and stoneclippers conceptions, unless prevented by governmental authority in all the cities of the third class and in the townships and counties of the state of Pennsylvania; Therefore be it

Resolved, That the Fairmount Park Art Association, in annual meeting assembled, enthusiastically endorses the recommendation made by Governor Sproul that a State Art Commission be authorized and appointed, to have jurisdiction throughout the State, excepting in cities of the first and second classes." 
By Act of May 1st, 1919, the State Art Commission was established. At the same meeting the following resolution, also offered by Mr. Crawford, was unanimously adopted:

"Whereas The Fairmount Park Art Association has for a number of years consistently urged the improvement of the banks of the Schuylkill as a most pressing public object and such embankments, as those of the Seine in Paris, are, in reality, vast works in sculpture; and

WhEREAS No finer memorial to the men from Philadelphia, who fought for the freedom of the world, could be devised than a magnificent, open, free, central improvement along both banks of the Schuylkill from Fairmount Park southward, including a new bridge at about Vine street, and

WhEREAS The construction of the 'Schuylkill Embankments' would present many opportunities for monuments to individuals among both the American and the other Allied forces and, in addition, the work would offer opportunity for employment to returning soldiers, sailors and marines; Therefore be it

Resolved, By the Fairmount Park Art Association, in annual meeting assembled, that the public authorities of Philadelphia be urged to undertake the reclamation and improvement of a section of the Banks of the Schuylkill and the construction of a new bridge at Vine Street as the War Memorial of the City of Philadelphia."

Immediately following the amendment to its Charter in 1906, under which the Association was empowered to "Promote and foster the beautiful in the City of Philadelphia in its architecture, improvements and general plan," the study of the larger problem of the development of the city beautiful presented itself.

When the Fairmount Parkway to connect the park with the centre of the city was assured, the project of a Municipal Art Gallery was earnestly discussed and the site of the former water reservoir was tentatively suggested for the latter.

In April, 1907, the trustees appointed a commission of experts to prepare a comprehensive scheme and after careful consideration a report was made in December of the same year, outlining the plans and purposes associated with a broad avenue leading to the park. The report was voluminous, was accompanied by maps and, after meeting with the approval of the Association, was presented to the Commissioners of Fairmount Park and to the City of Philadelphia, finally to be used as the basis for that great development, which will render our city one of the most attractive communities in the United States.

This commission consisted of Paul P. Cret, Horace Trumbauer and C. C. Zantzinger, Chairman, all eminent in their 
profession, and their good work was supplemented at a recent date by that of Jacques Gréber, of Paris, whose final plans are now in course of development.

As these plans mature and the splendid avenue with its Municipal Art Gallery at the western end appears, the service rendered by this Association in the fostering and promotion of this enterprise will be better understood and appreciated by the community as an action, for which after generations will be forever grateful.

\section{0}

The report submitted at the Annual Meeting on January 15, 1920, notes:

"The Fairmount Parkway, an epoch-making improvement, by far the most important work of the kind ever undertaken by any American city, is practically completed in accordance with the plans prepared by this Association and accepted by the City in 1909, completed, that is to say, so far as the roadway is concerned, while the work of embellishment, whether by planting or by the erection of such monumental and other structures, as are essential to the realization of the project as a whole, is proceeding as rapidly as could reasonably be expected, when due allowance is made for the interruption caused by the war.

"The feature of the Association's plan, that consists in the grouping of the art institutions of the city around the great plaza at the upper end of the Parkway, has received the cordial approval of the authorities and definite assignments of spacious sites for the Pennsylvania Academy of the Fine Arts, the Pennsyivania Museum and School of Industrial Art, the Free Public Library and the Municipal Court have already been made, while the work of erecting the central and crowning feature of this whole project, the superb Municipal Art Museum, on the site of the old reservoir on Fairmount itself is actively progressing.

"The character of this museum will set a very high standard for the civic improvements, of which it will be the dominating feature, and the influence for good, which it will exert in elevating the city's ideals and broadening its vision of the things that ought to be, is incalculable."

The report continues:

"In accordance with the generous offer of Mr. J. Bunford Samuel to anticipate the provisions of Mrs. Samuel's will by 
erecting himself the first of the series of statues emblematic of the history of America, which is to constitute the principal feature of the memorial, the statue of Thorfinn Karlsefni, the commission for which was awarded to the Icelandic sculptor, Einar Jonsson, has been completed and, having been approved by the Art Jury, has been erected in bronze. The statue is a noble and vigorous embodiment of the spirit of the Norsemen, with whose adventures American history begins, and sets a high standard for the series, of which it is the leader. The city is to be congratulated on the auspicious beginning of a magnificent scheme of civic embellishment signalized by the erection of this impressive statue, whose generous donor has moreover by his public spirited action indicated the kind of service, which art and art alone has it in its power to render in the perpetuation of the memories, on the preservation of which the higher life of communities so largely depends."

\section{1}

The report submitted at the Annual Meeting on January 13, 1921, called attention to the approaching Fiftieth Anniversary of the founding of the Association and a special committee was authorized to prepare plans for a suitable celebration of this important event. At this meeting Professor Paul P. Cret presented a tentative plan demonstrating the availability of the Parkway and Schuylkill banks for the SesquiCentennial Exhibition of 1926; our fellow member and trustee, Andrew Wright Crawford, Esq., followed with an illustrated address indicating many permanent public improvements that would be secured by the adoption of these plans.

The report further noted:

"In the midst of pleasurable happenings and in congratulations over the success attending the growth of the Association there is one event that has cast a shadow, the effect of which will last for a long period. In April of 1920, Leslie W. Miller resigned as a member of the Board of Trustees and as Secretary, thus severing relations that have continued for many years." The Board adopted a minute* which later was incorporated in a booklet artistically ornamented in Renaissance design and forwarded to Dr. Miller in his New England home. This action was unanimously approved and hearty

*See page 124 . 
good wishes of the Association in annual meeting assembled were sent to Dr. Miller.

Joseph A. Steinmetz and the Hon. James M. Beck addressed the meeting, endorsing enthusiastically the proposition for a World Fair in Philadelphia in 1926 and showing the splendid advantages from every point of view in the selection of the Parkway and the banks of the Schuylkill for the site.

A further note was made of the completion and erection of the statue of Thorfinn Karlsefni, the generous gift by J. Bunford Samuel, Esq., thus anticipating the initiation of his wife's munificent bequest.

The endeavors and accomplishments of the Fairmount Park Art Association in its first fifty years, thus recorded, mark, it is hoped, but the beginning of its career. 


\section{LIST OF OFFICERS FROM THE ORGANIZATION OF THE ASSOCIATION}

\section{PRESIDENTS}

Anthony J. Drexel. . . . . . . . . . . . . . . . . . . . . . . . . . 1871-1893 John H. Converse. . . . . . . . . . . . . . . . . . . . 1894-1900; 1904-1909 Charles H. Howell. . . . . . . . . . . . . . . . . . . . . . . . . . . . . 1900-1902 JaMES M. BECK. . . . . . . . . . . . . . . . . . . . . . . . . . . . . . . . . 1903-1904 Edward T. Stotesbury.

1909-1916 Charles J. Cohen.

\section{VICE-PRESIDENTS}

H. Corbit Ogden.

Charles H. Rogers.

Joel J."Baily.

Alexander Brown

1916-

George B. Roberts

Charles C. Harrison

Frank Thomson.

William W. Justice.

Ferdinand J. Dreer.

Charles E. Dana

Edgar V. Seeler.

John T. Morris.

John H. Converse.

Charles J. Cohen.

E. Burgess Warren.

James M. Beck

Henry K. Fox.

1871-1876

1876-1886

1886-1903

1887-1893

1887-1898

1894-1907

1898-1899

1899-1900

1900-1902

1900-1914

1904-1909

1909-1915

1909-1910

1912-1916

1916-1917

1916-

1916-

\section{TREASURERS}

James L. Claghorn

1871-1885

Thomas Hockley.

1885-1892

Henry K. Fox

1892-1899

James W. Paul, JR

1899-1908

William W. Justice

1909-1914

John IV. Pepper.

1915-1918

IV. Hinckle Smith.

1919-

SECRETARIES

John Bellangee Cox $1871-1875 ; 1877-1887$

John B. Robinson 1875-1877

Charles H. Howel 1887-1900

Leslie W. Miller. 1900-1920

Roland L. TAYlor 1920

\section{TRUSTEES}

Joel J. Baily

1875-1903

WescotT Bailey

$1895-1900$

Joseph William Bates

1884-1885

James M. Beck

1902-

Chapman Biddle.

1872-1880

Frederick Meade Bissell

1871-1874

Charles L. Borie, Jr.

Archibald Campbel.l.

James L. Claghorn .

1871-1884

J. Raymond Claghorn

1887-1892

Charles J. Cohen.

$1877-$

John H. Converse.

1893-1910 
John Bellangee Cox

1871-1887

Andrew Wright CraWford

1903-

Charles E. Dana...

1909-1914

Thomas Dolan...

1871-1897

Thomas J. Dolan.

1897-1905

Ferdinand J. Dreer

1889-1898

Anthony J. Drexel.

1871-1893

George W. Elkins

Henry K. Fox.

1914-1917

$1871-$

William D. Gemmill. . . . . . . . . . . . . . . . . . . . . . . 1875-1875

Henry C. Gibson.

$1871-1875$

LinCOLN GODFREY.

$1885-1888$

Frederick GrafF.

1888-1889

Charles J. Harrah.

1880-1888

George L. Harrison, Jr.

1918-1919

A. G. Hetherington

$1888-1921$

Thomas Hockley.

1880-1892

William J. Horstmann

1871-1871

Charles H. Howell

1871-1902

William W. Justice.

Albert Kelsey. .

1900-1914

Walter Lippincott

1909-

J. Franklin McFadden.

1871-1883

John D. McIlhenny.

1918-

James MacAlister

1918-

L.eslie W. Miller

1897-1913

Joseph Moore, JR

1895-1920

John T. Morris.

1876-1887

George W. Norris

1885-1915

H. Corbit Ogden.

1915-1917

J. Rodman Paul.

1871-1879

James W. Paul, JR

1920

John Worrell Pepper

$1897-1908$

1905-1918

Henry Pettit. .

$1887-1888$

Eli Kirk Price.

1914

John B. Robinson.

1875-1877

Charles H. Rogers

John Sartain.

1872-1884

1893-1897

Edgar V. SeEler

1909-

Frederick R. Shelton.

1881-1894

D. C. Wharton Smith

1884-1886

Joseph Frailey Smith.

1871-1874

W. Hinckle Smith.

1919-

Joseph Allison Steinmetz.

1901-

E. T. Stotesbury.

1909-1915

William Struthers, Jr

1876-1883

Roland L. Taylor.

1911-

Edward H. Trotter

1871-1871

E. Burgess Warren...

1890-1917

George S. Webster

1916-

Cornelius N. Weygandt.

1889-1907

Samuel S. White.

1871-1879

Joseph Widener.

1916-

J. Sergeant Price

D. Stuart Robinson

1907-1921 
A BRIEF ACCOUNT

of the

FOUNDERS

and

CERTAIN OTHERS

by

CHARLES J. GOHEN

President 


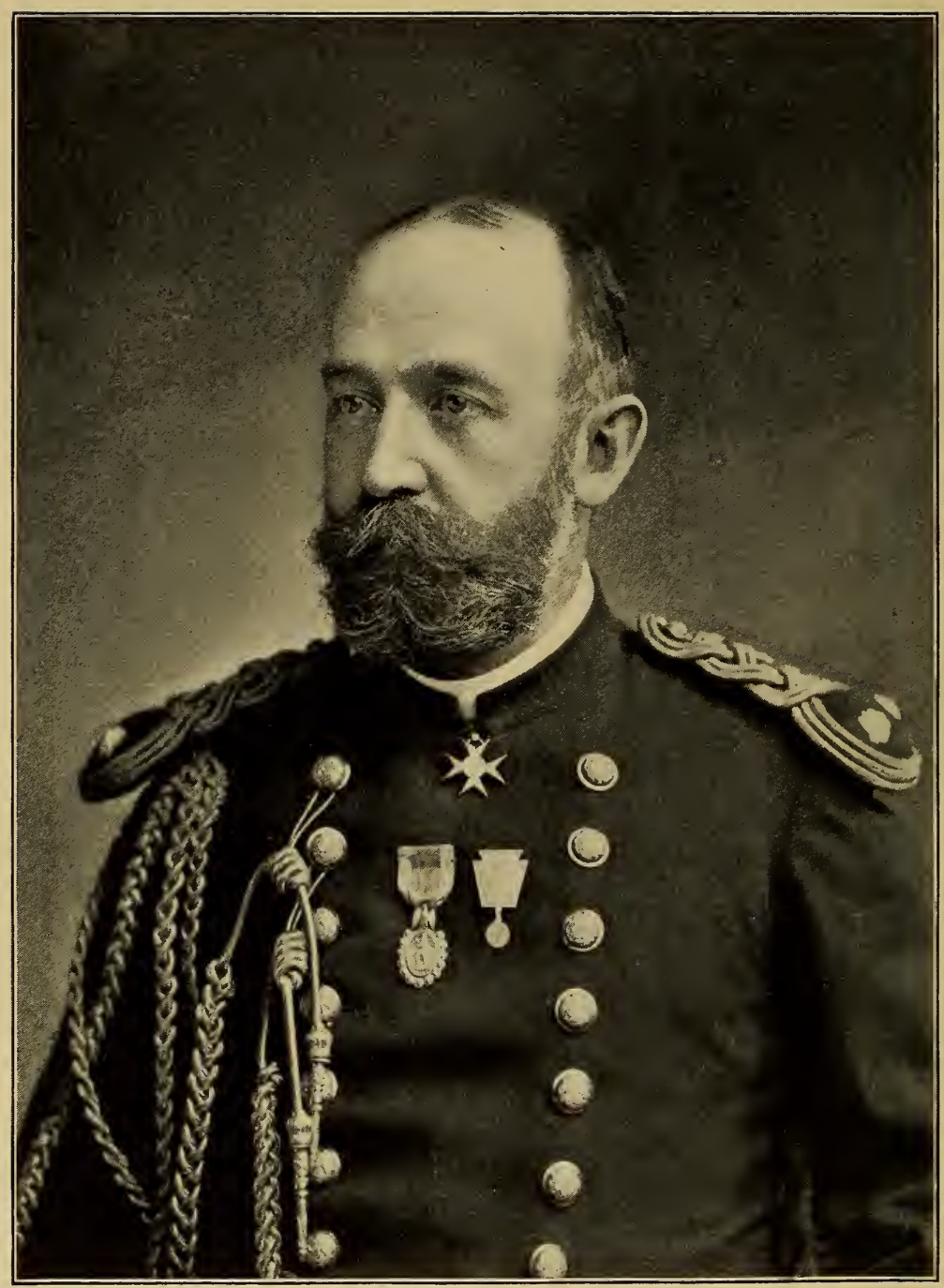

COLONEL CHARLES H. HOWELL

Founder of the Fairmount Park Art Association in 1871 President, 1900-1902 


\section{CHARLES H. HOWELL}

\section{Founder and Member of the First Board of Trustees}

President of this Association, died on June 18, 1902. He was born in Philadelphia on February 10, 1848, his father being Henry C. Howell.

From early manhood he was prominently identified with various State military organizations. He was for many years an active member of the First City Troop and was an Honorary member of that body at the time of his death. He served as lieutenant colonel on the staff of Governor Hastings and as division quarter-master on the staff of General Snowden.

A man of great public spirit, he took a prominent part in the affairs of many philanthropic societies and associations. During the Spanish-American War he was president of the Philadelphia Red Cross and he held this office at the time of his death. He was also vice-president of the Philadelphia Lying-in Charity, and treasurer of the Mercantile Beneficial Association. He was an active friend of, and a generous contributor to, many charities. The following clubs and societies numbered him among their members: The Union League, the Art Club, the Country Club, the Bachelors' Barge Club, the State in Schuylkill and the Sons of the Revolution.

Of the Fairmount Park Art Association he was practically the founder and its leading spirit for many years. A charter member, he served on the Board of Trustees from its inception, as secretary from 1886 to 1900 and as president from 1900 to the time of his death.

$\mathrm{He}$ is survived by his widow, who was Miss Annie M. Fitler, daughter of the late Edwin H. Fitler, Mayor of Philadelphia, and by three daughters and one son.

At the thirty-first Annual Meeting held December 18, 1902, Mr. Charles J. Cohen spoke as follows:

Mr. Chairman:-“"The privilege of a few minutes is asked in which to speak of the personality of the late Colonel Charles H. Howell, founder of this Association and its President at the time of his demise.

"Five and twenty years ago, walking down Chestnut Street one winter morning, a sign in the front of Earle's picture gallery attracted my attention. It read somewhat in 
this fashion: 'On exhibition-photographs of the Dying Lioness, a bronze work recently acquired by the Fairmount Park Art Association; those interested in adorning Fairmount Park with statuary are invited to become members of the association.'

"Interested in art and believing civic adornment to be a most meritorious virtue, I entered, admired and became a member. Some time later, as a member of the Board of Trustees, I became acquainted with Charles H. Howell and soon learned to regard him with feelings of the greatest esteem, as well as admiration for his excellent qualities and notably his devotion to the work of this Association. He has often told me of the inspiration that came to him in 1871 and how he called upon a few men in Philadelphia, noted for their public spirit, their interest in art and their willingness to aid in what we now term making a 'City Beautiful.' The late Anthony J. Drexel consented to serve as President, giving it all the power of his name and character until his death, it being one of the very few Associations over which he consented to preside.

"It is most interesting to turn the pages of the earlier reports, looking at the extremely small sums of money that were obtained, watching the very slow growth of the special funds for the Meade, Garfield and Grant Memorials, all of which, happily, Colonel Howell lived to see realized in a most admirable and artistic manner, and particularly does the thought often come to my mind of the periods of depression, through which he passed, when the development of the Association seemed to stand still, and when the paucity of numbers at meetings, both of the Board of Trustees and at the annual gatherings of the Association itself, was a most discouraging feature. But the sturdy sense of responsibility and the latent feeling that the community would at some time either far or near understand and be willing to develop and support the ideals, for which the Association has always stood, were the mainstays that carried him through all these trials. I can speak of these things, because they are now of the past, but they were serious when they happened, and we cannot be too grateful or too appreciative of the character that will be willing at great personal sacrifice to withstand the pressure for abandonment that has many times overturned enterprises of a like nature. It was always Colonel Howell's endeavor to interest intelligent and art-loving citizens and to give them 
part of his enthusiasm in the development of the adornment of the park and city; and he was always willing to have others receive any honor or praise to be given while he would accomplish the necessary work.

"The conception of the Permanent Fund was put in shape as early as 1874 , to be followed by the creation of the Perpetual Memberships in 1895 . Both of these originated with Colonel Howell and were watched by him with a fatherly care, and nearly all of the Perpetual Memberships were obtained through his personal intercession.

"The last definite act was during the autumn of last year, when 1 accompanied him to the foundry in Philadelphia to examine the full-sized statue in plaster which had been completed by the sculptor for the Monumental Memorial, now in course of erection in West Fairmount Park. The last time I grasped his hand was during the winter of the present year, when he was lying on a bed of sickness, but with a cheerful, bright and clear mind he showed an eager desire to know of the progress and welfare of the Association which we had both served from early manhood. In leaving I used the expression 'Good-bye,' my usual form of salutation, but it seemed to impress him differently, and at his earnest solicitation I withdrew it, substituting the formal au revoir, but I was not to see him again.

"But I would remind you that the loving and admiring friends of Charles H. Howell did not wait until he was gone from among them to note his worth. On the occasion of the twenty-fifth anniversary of the incorporation of the Society, a number of us gathered together and marked the occasion by the adoption of suitable resolutions, which were engrossed and presented to him, by the placing of his name on the honorary roll of membership, and by the presentation of a silver loving cup, which meant far more in the minds and hearts of those associated with the occasion, than they could express. With the growth of our community and the occasion for the larger amount of work to be accomplished in each man's life, this appreciation of men's deeds, whilst they are still with us, is not amiss. We are no less cognizant of the aid and support given by that gracious woman, his partner in life, to these undertakings. To her and her honored father, the late Edwin H. Fitler, we know we are deeply indebted for many successes, instigated and suggested by Colonel Howell, seconded and carried out by them." 


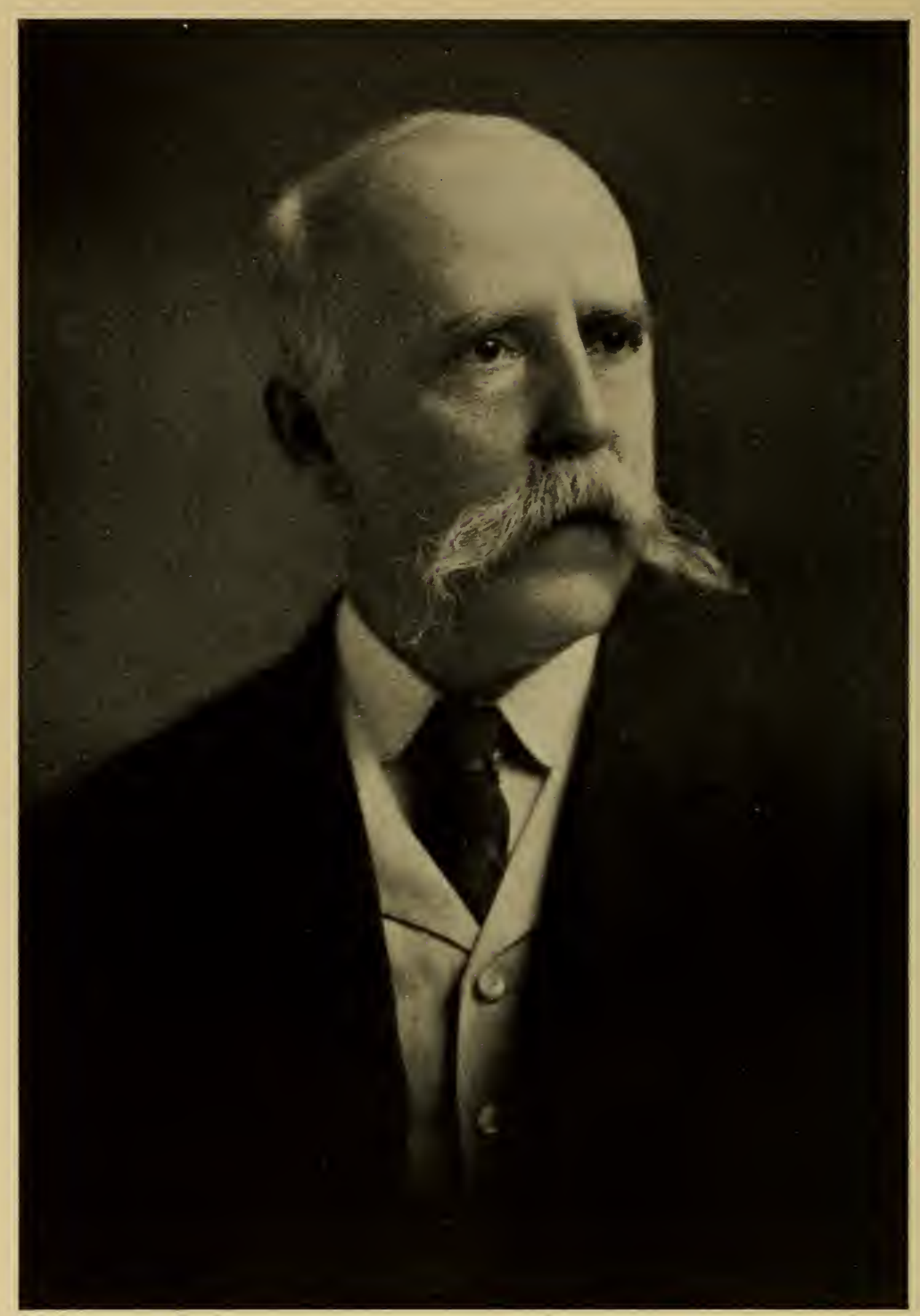

FREDERICK MEADE BISSELL

Founder and member of the first Board of Trustees 


\section{FREDERICK MEADE BISSELL}

\section{Founder and Member of the First Board of Trustees}

Frederick Meade Bissell was born in Cincinnati, Ohio, December 5, 1842, and made his home in Philadelphia in early youth. His education was obtained at the Episcopal Academy and later at the University of Pennsylvania, from which he was graduated in 1861 with the degree of Bachelor of Arts.

Mr. Bissell was the son of Israel Morey Bissell and Augusta Turner Meade and the great-great-grandson of General Israel Morey, who commanded a division of New England Troops during the War of the Revolution.

$\mathrm{He}$ was a member of the Sons of the Revolution; Historical Society of Pennsylvania; University Club; Germantown Cricket Club (Secretary 1879-1891) and Secretary of the International Cricket Committee 1883-1891; he served in the first regiment Gray Reserves National Guard of Pennsylvania during the Civil War 1862-1863.

In 1870 Mr. Bissell married Sarah Corbit Perot, daughter of Elliston Perot and Caroline R. Corbit. Mrs. Bissell lives at Atlantic City; their son, Elliston Perot Bissell, an architect, born in 1872, lives in Germantown and in 1901 married Anna Randolph Wurts, daughter of Charles Stewart Wurts.

Mr. Bissell was associated for some years with the Pennsylvania Railroad executive offices; he died in Germantown, January 10, 1908. 


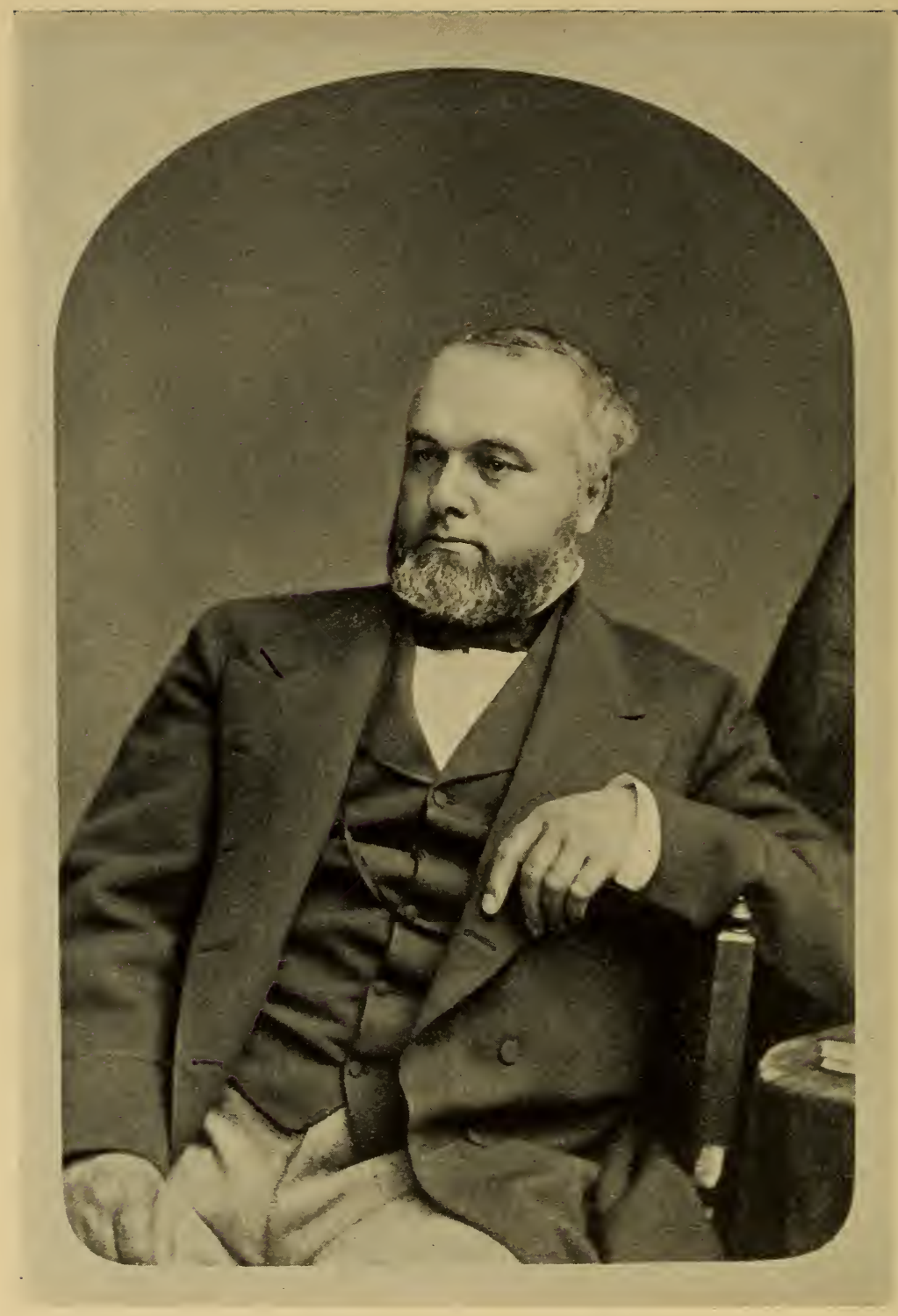

ARCHIBALD CAMPBELL

Founder and member of the First Board of Trustees 


\section{ARCHIBALD CAMPBELL \\ Founder and Member of the First Board of Trustees}

Archibald Campbell was born in Quilly, County Down, Ireland, December 31, 1824, and came to this country in 1844, when a youth poor and friendless.

His first employment was with David Milne as a designer of patterns, then with James C. Kempton at Manayunk, and on the latter's retirement in 1850 he rented a room and with three associates-mill hands-began weaving and in a few years had erected a series of mill buildings and had become the largest and most important manufacturer of his special character of goods in this section of the country.

His mansion on School Lane, Germantown, was situated in a tract of 60 acres well laid out and decorated and in his home was one of the finest libraries of the day. He possessed some excellent pictures.

He was a director of the Commercial National Bank from 1866 and was a generous donor to the Pennsylvania Academy of the Fine Arts.

Mr. Campbell died October 23, 1874, and has been described by his friends as a natural born leader of men; always bright, never despondent; and" his associates would remark that "they always felt safe when Campbell was about, since it was evident that affairs must go right."

$\mathrm{He}$ is described as dearly loving woods and fields and he would seize every opportunity to spend a day in the country, when business cares and anxieties were banished and he would enter joyously into the pastimes of the occasion. 


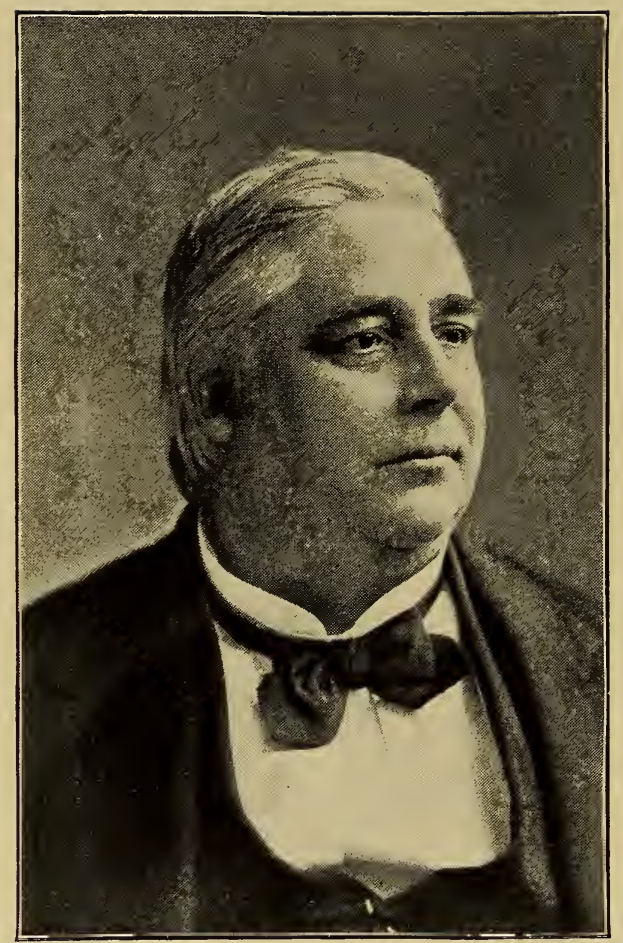

JAMES L. CLAGHORN

Founder and member of the first Board of Trustees

Treasurer 1871-1885 


\section{JAMES LAWRENCE GLAGHORN \\ Founder and Member of the First Board of Trustees}

James L. Claghorn was
and died August 25, 1884 .

The Claghorn family goes back to its register at the Lyon office in Edinburgh where the Cleggorne arms were entered in 1630. The name is of Celtic origin and is of great antiquity.

The first record in this country is of James Claghorn, living in Yarmouth, Massachusetts, in 1654, when he was active in suppressing the Indian Revolt called King Philip's War.

Then in a succeeding generation a Claghorn was a soldier in the Louisburg Expedition of 1745. Three of his descendants were in the Revolutionary War. Colonel James Claghorn continued the military record of the family, and one of his grandsons was Benjamin Alvord, Major General U. S. A. Col. Claghorn was in the regiment known as "Green Mountain Boys," and took part in the capture of Ticonderoga.

Col. George Claghorn, 1797, was the head of Hart's shipyard at Boston where the Constitution was launched.

John William Claghorn, the father of the subject of our sketch, was born in Massachusetts, 1789; he came to Philadelphia in 1810 and was a communicant at St. Andrew's Church. In 1814, returning to Boston, he enlisted in Col. Binney's regiment.

Coming back to Philadelphia, he became a member of the auction house of Myers, Claghorn \& Co., a director of the Philadelphia and of the Girard National Banks. He helped to organize and was the first Vice-President, later Treasurer, of the Northern Home for Friendless Children.

At the age of fourteen, James Lawrence Claghorn left school and went to work in earnest. For it was an auction store that he entered, and the work there was usually harder than in other places, the hours being longer-earlier and later-and the holidays rarer than in ordinary commercial houses.

Recognizing that his education was incomplete with the end of his school life, he gave much of his leisure to self-im- 
provement; his evenings, when not spent in the countinghouse, were devoted to reading, and the books that he read were such as to give instruction and to gratify an inherent taste for art and literature of an elevating character, resulting in the development of his taste for art, evidenced in the collection, as his means would permit, of engravings and pictures such as would cultivate his taste in that direction. When he could spare the money he would buy an engraving, if the subject or author interested him; so that he became, in the latter part of his life, the owner of one of the largest collections of engravings in the country. A noted patron of art, he was desirous of encouraging native talent, so that at one period he had more than two hundred paintings, the work of American artists. Many pictures he bought to help the artist, rather than for his own gratification as a collector. Later on in life, he became deeply interested in the Pennsylvania Academy of the Fine Arts, which was then on Chestnut Street above Tenth. Subsequently he became its President and, largely through his influence and his personal means, the present structure at the south-west corner of Broad and Cherry Streets was erected. Mr. Claghorn was also largely instrumental in securing the erection of the Academy of Music at Broad and Locust Streets.

In middle life he became a member of the firm and took his father's place.

So he passed the best years of his life in earnest attention to business, seizing moments of leisure for the gratification of his love for art, until the time came, when, having acquired a competency, he determined to retire from business and contemplated a visit to Europe. While he was making arrangements for a holiday of great enjoyment, the country became involved in the Great Rebellion of 1861-65. Full of love for his country and unwilling to act in a way that might seem a desertion in her time of trial, Mr. Claghorn gave up his contemplated foreign tour and applied himself diligently and earnestly to the duties of a true, loyal citizen in the support of the government. He was one of the earliest members of The Union League and was interested in collecting money for the raising and equipment of regiments to be sent to the front.

After the war he visited England, Scotland, Ireland, France, Switzerland, Spain, Italy, Egypt, Palestine, Turkey, Greece, Austria, Russia, Germany, Holland and Belgium.

Shortly after his return to Philadelphia, he became the 
President of the Commercial National Bank. For several years previously he had been a Director of the Philadelphia National Bank (as his father had been before him), so that he had proper training for the duties of his new position. He became also a manager in the Philadelphia Saving Fund Society, the oldest and the largest saving fund in the city. With most commendable diligence and industry he at once set about building up the bank so as to make it profitable to its stockholders. Not forgetting, however, the attractions of art, he covered the walls of his bank parlor with beautiful specimens of the choicest engravings, so that even the daily routine of business life might be enlivened by glimpses into the attractive world of art.

In the year 1869, when the Board of City Trusts was created by act of the Legislature (to which board is committed the vast estate left by Stephen Girard, as well as the other trusts of the City of Philadelphia), Mr. Claghorn was appointed one of the original board of twelve, and from that date until his death he gave much time and thought to the duties thus devolved upon him. He became Chairman of the finance committee, which place he held until the end of his life. 


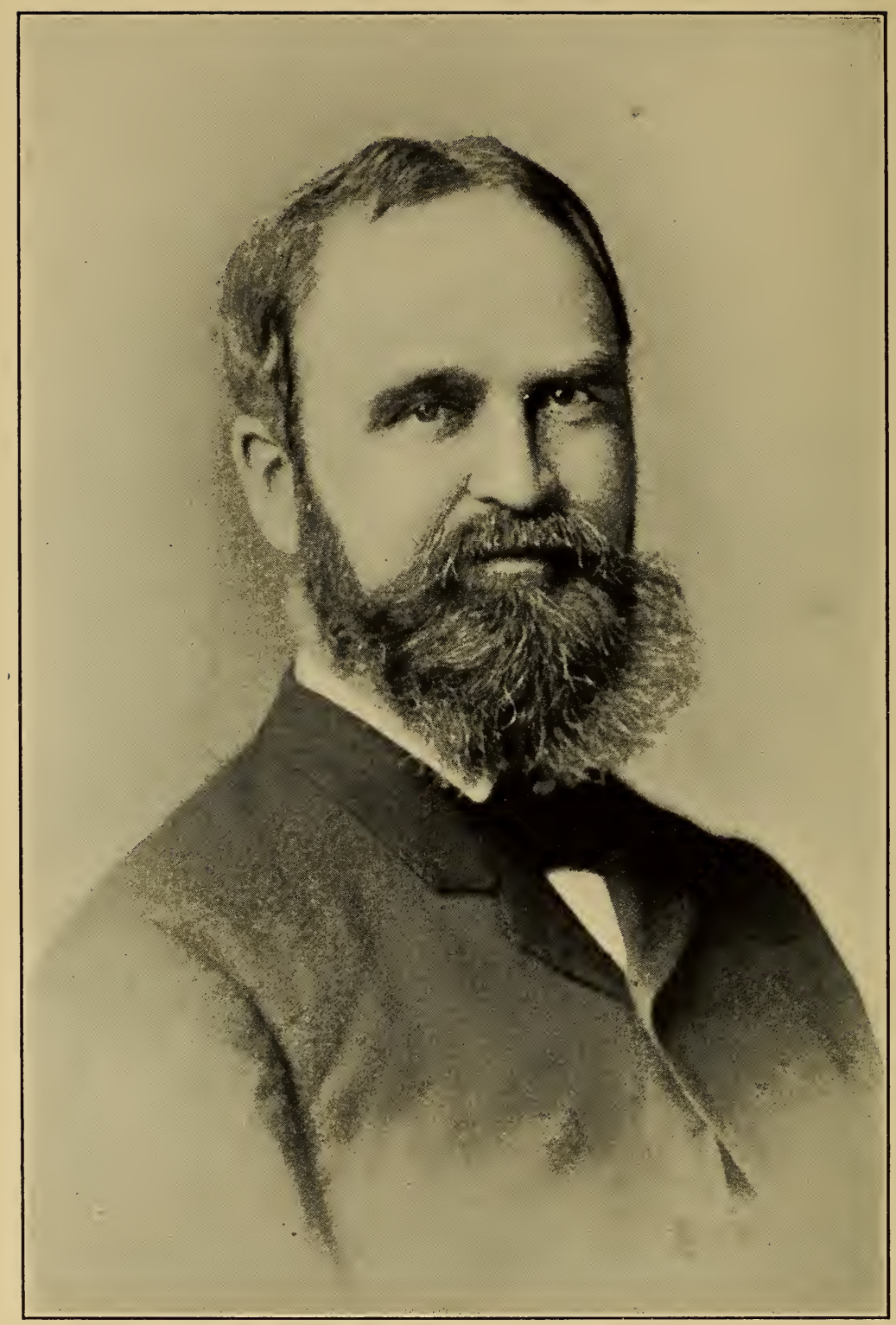

JOHN BELLANGEE COX

Founder and Member of the First Board of Trustees

Secretary 1871 to 1874,1877 to 1887 


\section{JOHN BELLANGEE COX}

\section{Founder and Member of the First Board of Trustees}

John Bellangee Cox was born in Germantown, Philadelphia, September, 1839, and died in Philadelphia January 3, 1888. His ancestors on both sides were people of distinction. Ive De Bellangee came over in the ship "Harp" with the French Protestants about 1780, the ship having sailed from London and put in first at Barnegat, N. J., finally reaching Philadelphia. Although a Calvinist he joined the Society of Friends and was married in Philadelphia by Friends' ceremony in 1697 to Christine De la Plaine. Among the witnesses to the wedding was F. D. Pastorius, the founder of Germantown.

Through the generations the family became allied with the Stocktons on the one side and on the other in later years with S. S. Cox, of Ohio. On the wall of Christ Church in Philadelphia there is a tablet erected by William Cox to the memory of his brother, John Cox, who was drowned in the Delaware River in 1713. The Stocktons were descended from Richard Stockton, the signer of the Declaration of Independence.

John Bellangee Cox was a graduate of Lafayette College and, shortly after his admittance to the Philadelphia Bar, took a position as Secretary and Treasurer of the United Security Life Insurance and Trust Company, then situated at Tenth and Chestnut Streets. On the organization of the Fairmount Park Art Association he became a member of the first Board of Trustees and its secretary, and much of its early development was left to him, since he was well fitted for the undertaking of work of that character. He served as secretary from 1871 to 1886 with an interruption of three years, when the position was occupied by John B. Robinson.

Mr. Cox's death was sudden. He was seized with a heart attack whilst at the morning meal, expiring instantly. His interest in the Association from the beginning was pronounced and undoubtedly much of its subsequent success was due to his clear and strong personality. 


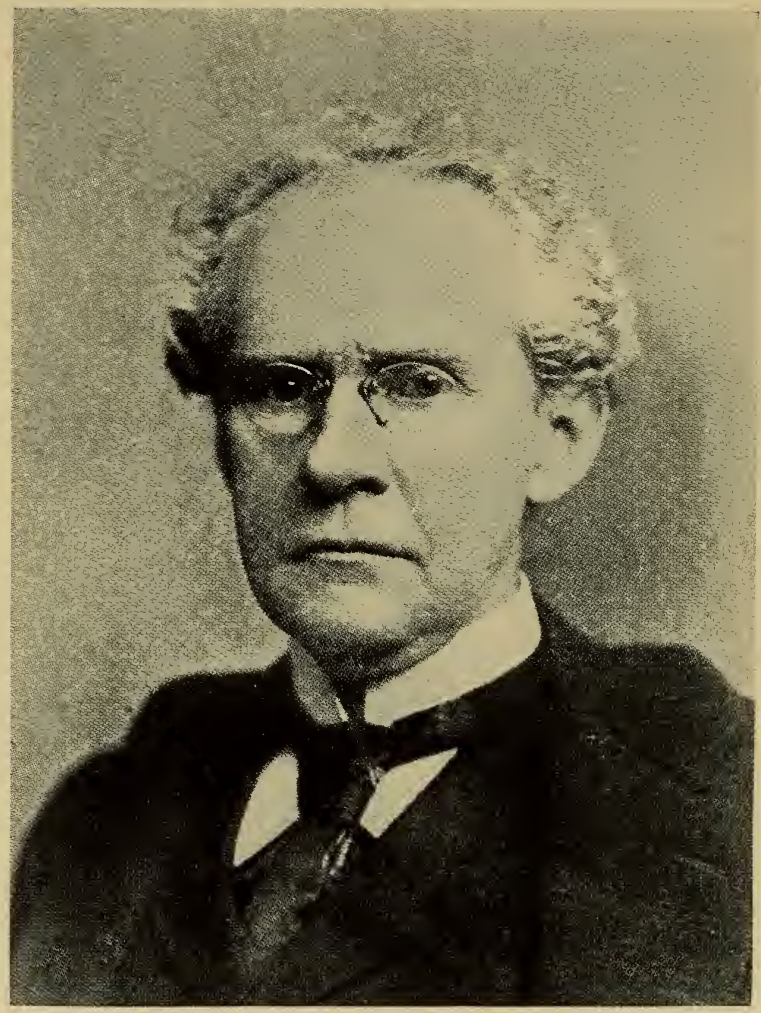

THOMAS DOLAN

Founder and Member of the First Board of Trustees 


\section{THOMAS DOLAN}

\section{Founder and Member of the First Board of Trustees}

Thomas Dolan was born in Montgomery County, Pennsylvania, October 27, 1834.

Educated in the Public School, his first entrance into a business career was at the age of fifteen, when he took a position in a retail dry-goods store, which he retained until 1856. He then joined a firm of importers of English hosiery which gave him the incentive to produce similar goods in this country, so that in the early sixties he equipped a mill in the manufacturing district of the city and in a few years, by industry and a keen knowledge of the public requirements in all classes of soft materials, he became a leader in that kind of goods. Having acquired a large fortune, he retired from business, directing his attention to public utilities, which were then beginning to be of decided importance.

Mr. Dolan organized the Brush Electric Company, both here and in New York and in Baltimore, and in 1892 accepted the Presidency of the United Gas Improvement Company, bringing that organization to a high state of efficiency, maintained throughout his connection with the Company until his withdrawal March 16, 1912.

A staunch Republican in politics, he was one of the first members of The Union League and its Vice-President for several years. He took an active part in supporting all movements looking to a high protective tariff, claiming that this was essential to overcome the great difference in the rate of wages between foreign and American work people.

Mr. Dolan was a director of the Fidelity Trust Company, the Finance Company of Pennsylvania and the Philadelphia Electric Company, and a trustee of the School of Industrial Art. Notwithstanding all these activities, he was a lover of literature and had a splendid library in his home at Torresdale on the Delaware.

Mr. Dolan died June 12, 1914. 


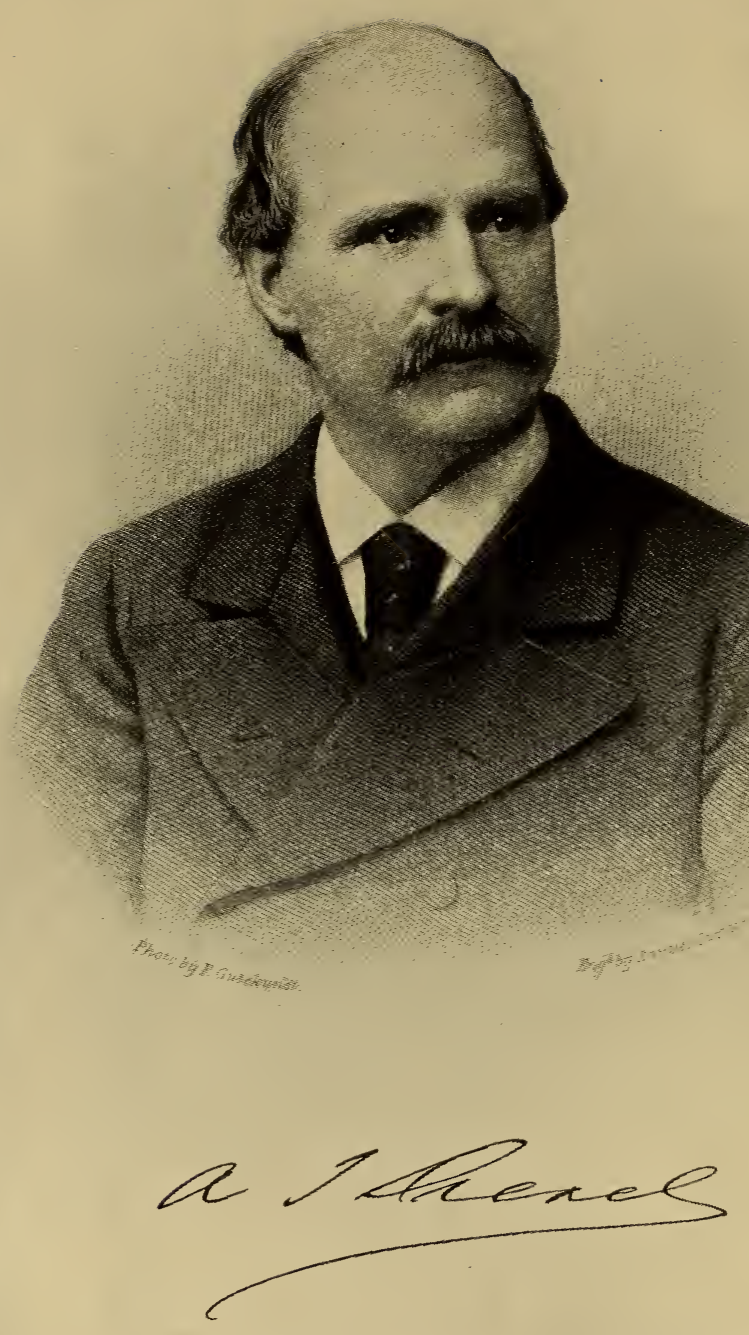

ANTHONY J. DREXEL

First President, 1871-1893 


\section{ANTHONY JOSEPH DREXEL \\ Founder and Member of the First Board of Trustees}

Anthony Joseph Drexel, the second son of Francis Martin Drexel, was born in Philadelphia September 13, 1826. His business career was begun at the age of thirteen in the banking house of his father and with the parent Drexel firm in Philadelphia his whole active life was identified. After the father's death in 1863, Anthony J. with his brother, Francis A., continued the business, later being joined by the third brother, Joseph W. The Paris house, Drexel, Harjes \& Company, was established in 1867 and the New York house, Drexel, Morgan \& Company, in 1871. The death of Francis A. Drexel in 1885 left Anthony in exclusive direction of the original concern in Philadelphia. It was essentially due to him that the world-wide extension of the Drexel interests was attained; the history of the banking business, of which he was the head, was the history of his life.

The distinguishing aspect of the business of the Drexels was the volume of their resources and their constant utilization for purposes of a public or semi-public nature. In each of the several departments of national, state and municipal loans and financial services to railway and similar great corporations, the Drexel transactions have aggregated many hundreds of millions of dollars.

An adequate review of the life of Anthony Joseph Drexel must involve a just appreciation of the character of the man in the aspect of the commanding power which he exercised. The following is taken from a memorial address by Bishop Potter:

"Mr. Drexel was distinguished above all by a moral nobleness in business, a kind of financial statesmanship, touched with the finest sensibility and lifted to the most exalted conception of great responsibility and opportunities. There is no test of character at once so searching and so final, as the possession, in whatever kind, of great power. He was a man who, holding a great power, wielded it for the greatest good; who held up the weak, sustained the public credit, befriended tottering fortunes and enterprises, put life beneath the very ribs of death and set the corpse upon its feet again, 
and all this in a fashion of such modest and unobtrusive naturalness, that we who saw him or knew of his doings never saw how great they were until he himself was taken away and we beheld them in their true light. Every honest enterprise was stronger, because it knew it could count upon his sympathy. Every equivocal and dubious enterprise of shrewd and unscrupulous men was weaker, because it was known that they would have to reckon with his unbending honesty and his uncompromising equity. Knaves dreaded his searching eye and knavish undertakings were the weaker, because he lived to detect and designate them. This was his moral power and men felt it everywhere and with unceasing force all the way to the end."

In his private beneficences Mr. Drexel was one of the most liberal men of his time, his aid being extended to churches of all denominations and to every hospital, disp snsary, home and benevolent organization in Philadelphia, as well as to countless individuals. He was one of the earliest and most generous contributors to the University of Pennsylvania in its recent development. In conjunction with his friend, George W. Childs, he established the Childs-Drexel Home for Aged Printers at Colorado Springs, Colorado.

The Drexel Institute of Philadelphia was founded and endowed by him and he had the satisfaction of seeing this great institution in full operation before his death, an example worthy to be followed by philanthropists throughout the land. In addition to the cost of the building, equipment, library and an endowment amounting to two million dollars, he bequeathed to the Institute an additional one million dollars. To the organization of its fundamental plan and to the details of its administration, he devoted a most conscientious care, aiming to make it a factor for the practical encouragement of art, science and industry. His chief motive was a deep sympathy for young people who are obliged to make their own way in the world and all the courses of instruction were formulated with this end in view, at the same time seeking to avoid tendencies which might make them dependents. He occupied the position of President of the Board of Managers of the Drexel Institute until his death.

The private life of $\mathrm{Mr}$. Drexel was characterized by qualities of honorable, sincere and noble manhood. His personal friends were the notable men of the time. Unassuming and modest, he avoided all public prominence, having declined 
the office of Secretary of the Treasury tendered by the President of the United States. Inheriting the artistic developments and tastes of his father, he was an enthusiastic collector of objects of art, of which his possessions ranked among the best selected and most valuable in the country.

He died at Carlsbad, Bohemia, June 30, 1893.

A splendid bronze statue of Mr. Drexel (executed by the eminent sculptor, Ezekiel), the gift of his former business partner, John H. Harjes, of Paris, to the City of Philadelphia, was unveiled in Fairmount Park with appropriate ceremonies in June, 1905.

It is now proper to take note of Mr. Drexel's interest in the Fairmount Park Art Association.

At the time of its foundation, a committee, being assured of his interest in art and in the welfare of his native city, tendered him the Presidency; he accepted the honor, considering it a distinction, and retained the office until his death, presiding at the meetings of the Board of Trustees and always being willing to give time and attention to the many problems, financial and otherwise, that confronted the management in the early years of its career. In fact it is recognized that the formation and additions to the Permanent Fund were made possible by the knowledge that his guiding hand would ensure stability to its investments, a policy that has been maintained and one that it is earnestly hoped never may be departed from.

It is believed that the Presidency of this Association (save only the Drexel Institute) was the only executive position that he consented to accept. 


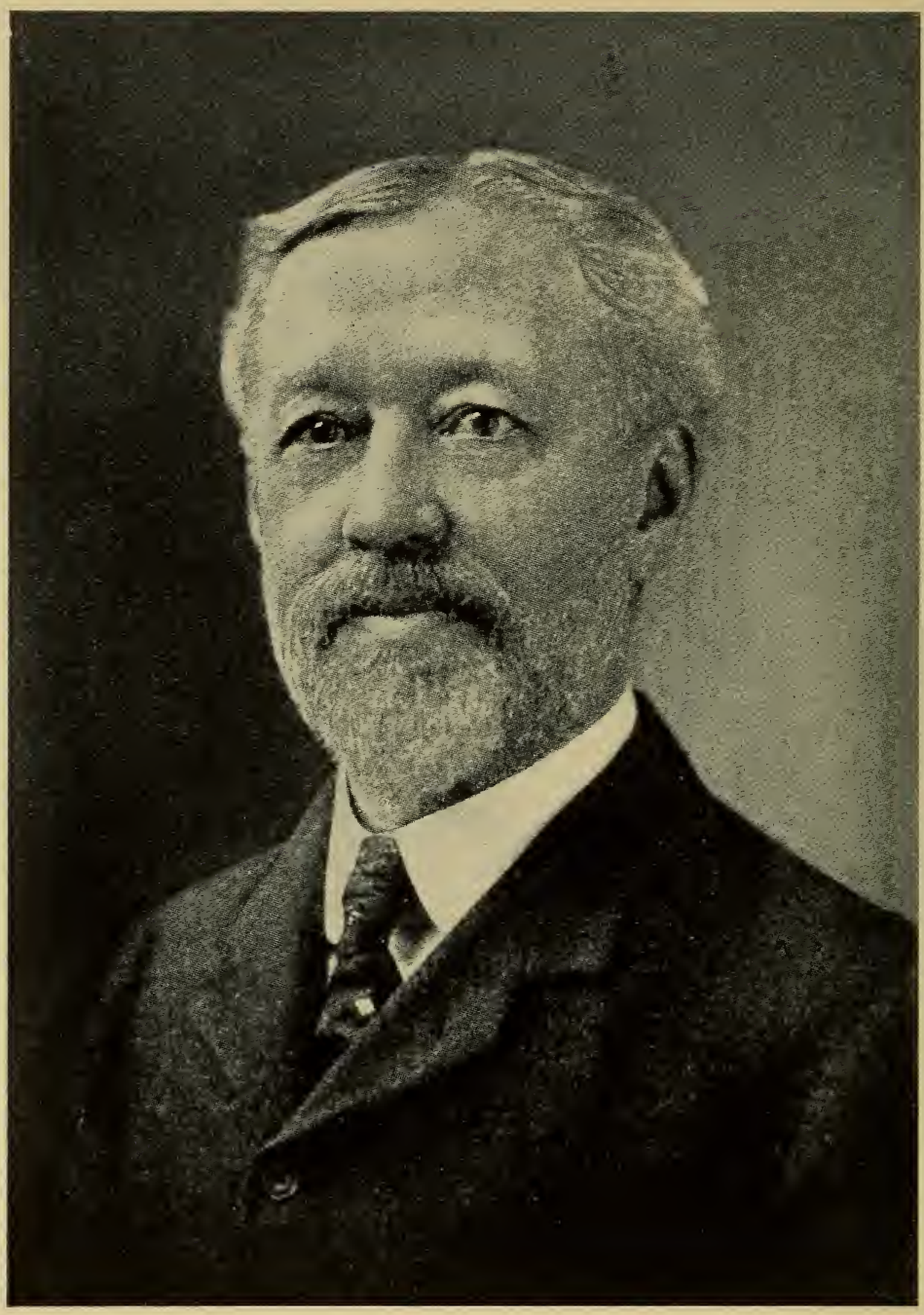

HENRY K. FOX

Founder and only surviving member of the original Board of Trustees, still identified with the present management 


\section{HENRY K. FOX}

\section{Founder and Member of the First Board of Trustees}

Henry K. Fox was born in Philadelphia September 21, 1847 , and was educated in the public schools and the Central High School. He graduated from the Law School of the University of Pennsylvania in 1878 . His father was the Hon. Daniel M. Fox, Mayor of the City of Philadelphia, 1869-1871.

Henry K. Fox is the only member of the original Board of Trustees now surviving, who still serves on the Board; he is now Vice-President of the Association.

It was in the year 1871 that Mr. Fox with Charles $\mathrm{H}$. Howell, his neighbor, conversed frequently about the future development of Fairmount Park and the possibilities of its adornment with statuary and other works of art.

The extensive plans for the Park, just completed under the guidance of the Commissioners, the body recently authorized to undertake these important measures, had been formulated, and it was considered opportune to form an organization of men and women to advise in the conduct of the enterprise and to enlist the sympathy and aid of the community. Out of this grew the Fairmount Park Art Association and we are indebted to Messrs. Howell and Fox for their initiative and enterprise in originating it.

Mr. Fox has been in active practice of the law for the past forty years, being especially interested in that phase relating to real estate, and his counsel and judgment in the practical conduct of the affairs of the Association have been of value.

For many years he served as Treasurer, devoting very many hours and days to the care of the accounts, until finally they became so numerous and varied as to require a staff for their administration. 


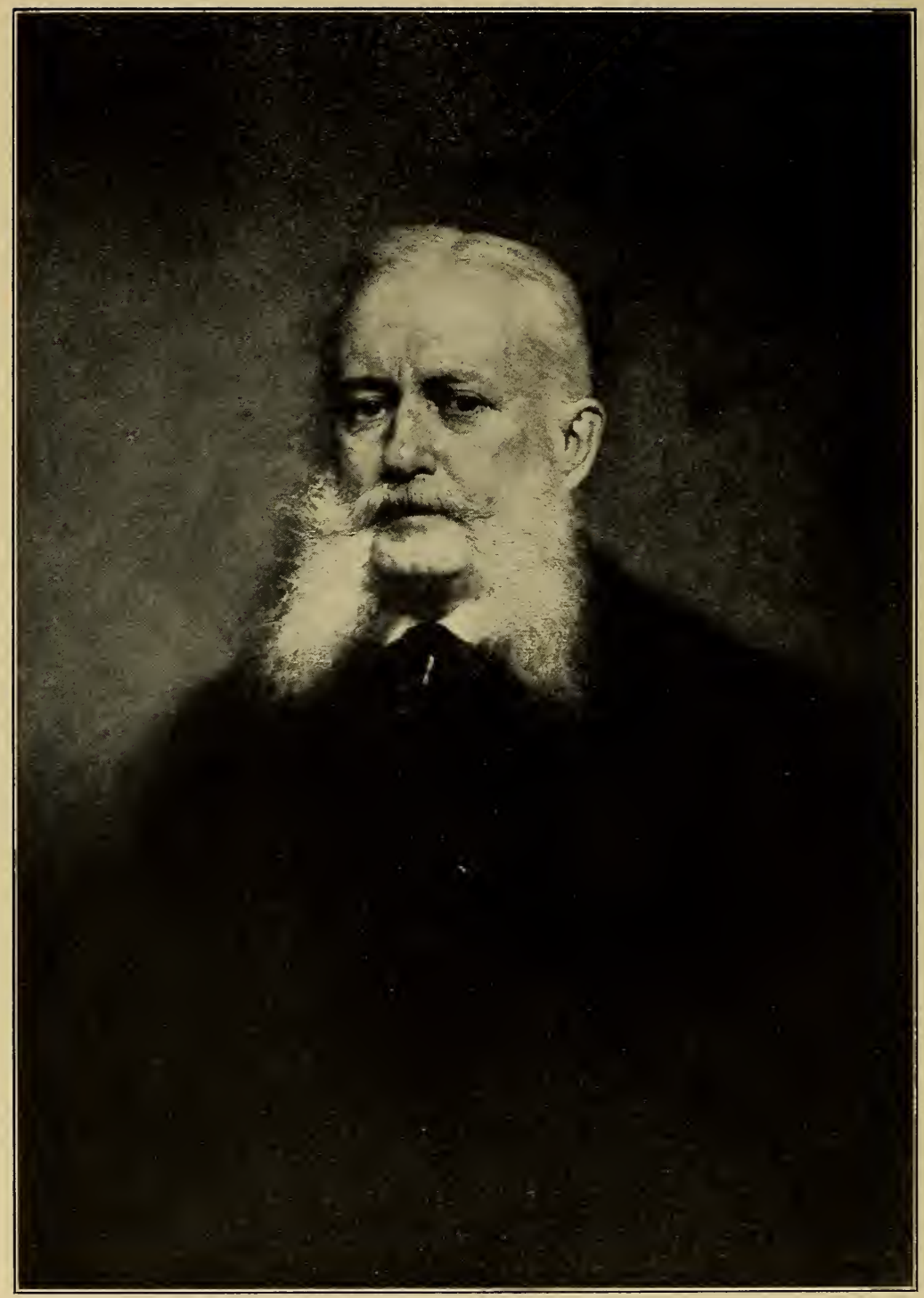

HENRY C. GIBSON

Founder and Member of the First Board of Trustees 


\section{HENRY C. GIBSON}

\section{Founder and Member of the First Board of Trustees}

Henry C. Gibson was born in Philadelphia in 1830. His father, John Gibson, came to this country from the North of Ireland and in 1856 founded the Gibsonton Mills Distillery on the Monongahela River near Pittsburgh. Upon his death in 1865 his son Henry succeeded to the business, in which he continued for some years, finally retiring from active participation to devote his time to public work and benefactions and to the cultivation of art, in which he was deeply interested.

He was a director of many financial institutions. Mr. Gibson was closely identified with the Pennsylvania Academy of the Fine Arts, having been a director from 1870 and its Vice-President from 1890 to 1891 ; also with the Hospital of the University of Pennsylvania, to which latter's new building he was one of the largest contributors when it was erected in 1876.

But his chief interest lay in his collection of French masterpieces, which hung on the walls of his residence in Walnut Street above Sixteenth and comprised examples of Diaz, Von Marcke, Zamacois, Millet, DeNeuville, Détaille, Munkaczy, Dupré and Cabanel, whose "Birth of Venus" has a wide celebrity. Daubigny and Rosa Bonheur are also represented and, although this does not complete the list, it gives a fair representation of the quality of the collection.

One of the most notable contributions to art was made by Mr. Gibson in his bequest of his superb collection to the Pennsylvania Academy of the Fine Arts.

One of his benefactions was the endowment of the Gibson wing for incurables at the University Hospital, as also many generous contributions to various departments of the University of Pennsylvania.

Mr. Gibson died in Philadelphia December 20, 1891. 


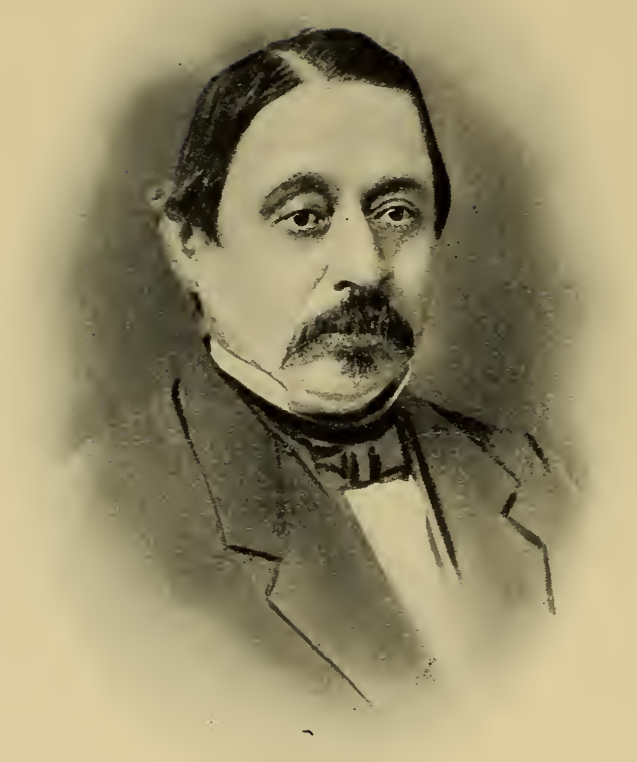

WILLIAM J. HORSTMANN

Founder and member of the first Board of Trustees 


\section{WILLIAM J. HORSTMANN}

\section{Founder and Member of the First Board of Trustees}

Born in Philadelphia in 1819, William J. Horstmann was the oldest son of William H. Horstmann, who in 1816, at Third and Arch Streets in this city, established the business of the manufacture of narrow textile fabrics and military equipment, now being continued by his descendants as William H. Horstmann Company (Incorporated), in Philadelphia and New York.

Mr. Horstmann was educated at the private school of Mr. John Beck at Lititz, near Lancaster, Pennsylvania. He was fortunate in receiving a good training from a sympathetic teacher, whose character left an impress, which had a decided influence throughout his career.

At an early age Mr. Horstmann became associated with his father's business and in 1843 he and his younger brother, Sigmund H. Horstmann, were admitted to full partnership. After the retirement of their father two years later, the brothers continued the business under the old style of William H. Horstmann and Sons for the next twenty-five years.

He was one of the founders and the President of the Philadelphia School of Design for Women and also of the Philadelphia Lying-in Hospital and Training School for Nurses; a founder and member of the original Board of Trustees of the Fairmount Park Art Association; President of the Teutonia Fire Insurance Company and of the German Benevolent Society of this city; a Trustee of the German (now Lankenau) Hospital of Philadelphia; one of the early members of the Franklin Institute, the Academy of the Natural Sciences, The Union League, and numerous other associations of the city.

Mr. Horstmann was much interested in the Centennial Exposition in 1876 and took an active part in its inception, having been appointed by the Governor of the State one of the Pennsylvania Commissioners.

After a brief illness, he died on May 10, 1872. 


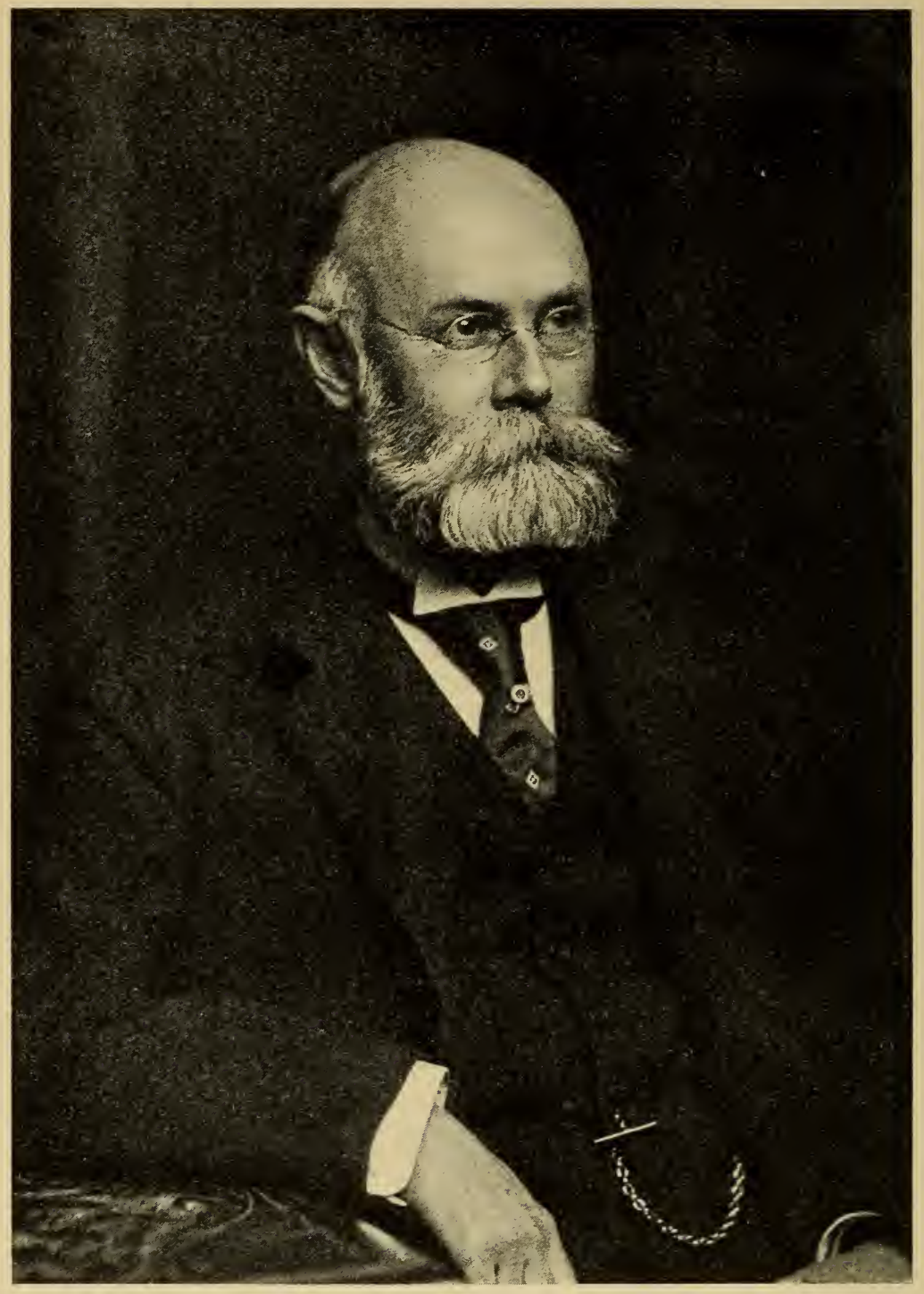

WALTER LIPPINCOTT

Founder and Member of the First Board of Trustees 


\section{WALTER LIPPINCOTT}

\section{Founder and Member of the First Board of Trustees}

Walter Lippincott was born in Philadelphia March 21, 1849, the son of Joshua Ballinger Lippincott and Josephine Craige.

A member of the class of 1868 of the University of Pennsylvania, he felt obliged to accompany his father to Europe before graduating. On his return to Philadelphia, he entered his father's publishing house, one of the leaders in the production of the best literature in the country.

Mr. Lippincott is a member of The Union League, Rittenhouse, Art, University, Merion and Philadelphia Country Clubs; Franklin Inn, New York Yacht and Corinthian Yacht Clubs; Deputy Governor of the Mayflower Society; Member of the Sons of the Revolution, the Historical Society and the Geographical Society.

Mr. Lippincott married Elizabeth Trotter Horstmann, daughter of Sigmund H. Horstmann and Elizabeth C. West, whom he survives. Their daughter, Bertha Horstmann Lippincott, was married in 1908 to Dr. Stricker Coles.

Mr. Lippincott still retains his membership in the Fairmount Park Art Association, although impaired health required his withdrawal from the Board of Trustees, of which he was an original member.

Mr. Lippincott is the founder of the Walter Lippincott prize of three hundred dollars, awarded annually for many years by the Committee of the Pennsylvania Academy of the Fine Arts, for the best figure-piece or marine painted in oil shown at the Exhibition. 


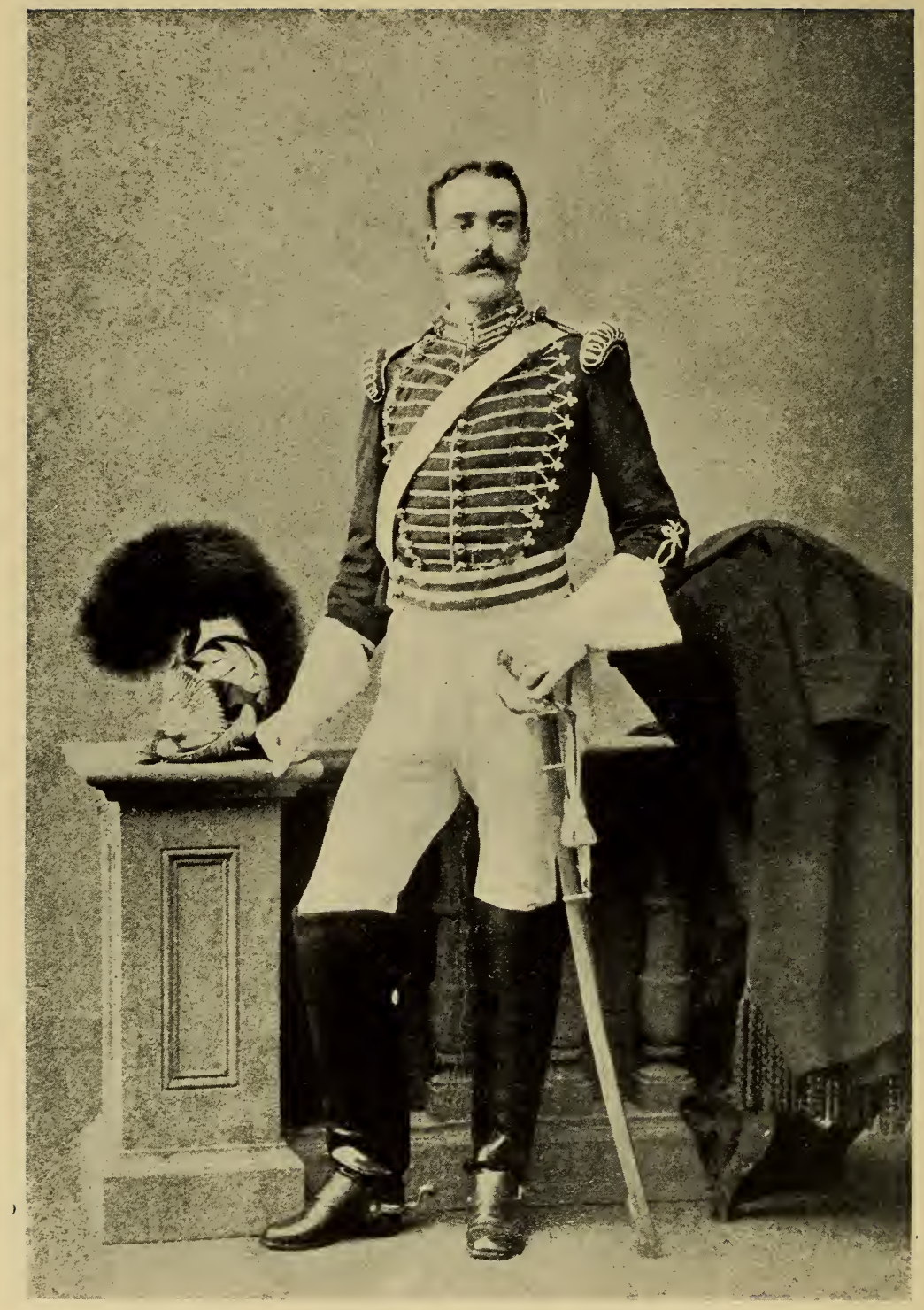

H. CORBIT OGDEN

Founder and member of the first Board of Trustees 


\section{H. CORBIT OGDEN}

\section{Founder and Member of the First Board of Trustees}

Henry Corbit Ogden was born in Philadelphia November 9, 1849, the son of Charles Smith Ogden and Emma Corbit.

$\mathrm{He}$ was an importer of silks, occupying a distinguished position as a merchant. He was an active member of the First Troop Philadelphia City Cavalry, but devoted much of his leisure to literary and antiquarian pursuits.

A member of the Society of Friends, he was educated at Friends' School, well known then as now for an admirable system of education, and later at Laval University in Quebec, Canada.

In 1877, Mr. Ogden married Eliza Chase Bowman, the daughter of Alexander Hamilton Bowman and Marie Louise Collins, their only issue surviving being Mrs. Marie Louise Embree, now living in New York City. Mr. Ogden died July 8, 1891. 


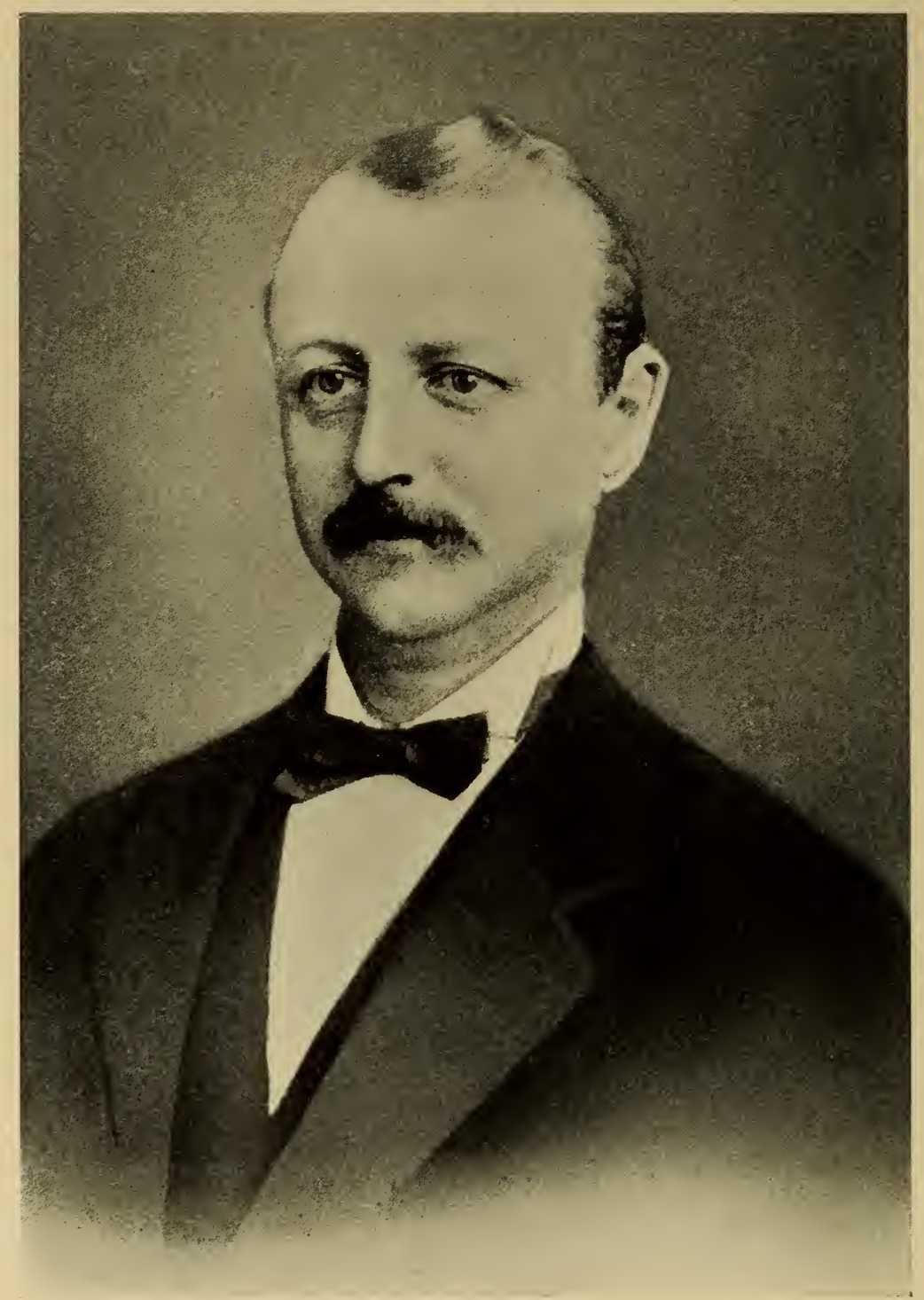

JOSEPH FRAILEY SMITH

Founder and member of the First Board of Trustees 


\section{JOSEPH FRAILEY SMITH}

\section{Founder and Member of the First Board of Trustees}

Joseph Frailey Smith was born in Reading, Pennsylvania, January 10, 1834, and died in Philadelphia June 26, 1880. His father was John Frederick Smith, one of Philadelphia's respected merchants. His grandfather, Frederick Smith, an eminent jurist, was Attorney General of Pennsylvania from 1823 to 1828 and later Associate Justice of the Supreme Court of the State. His great grandfather, the Rev. Johann Friederich Schmidt, a graduate of the University of Halle, an astronomer and a master of the Greek, Arabic and Hebrew languages, was the first of his family to come to this country. He was an eminent divine and one of the pioneers of his denomination to come to America. Seventeen years were spent by him as minister of St. Michael's Lutheran Church, Germantown, where his term of service included the Revolutionary War.

Mr. Smith was educated in the public schools and graduated from the Central High School of Philadelphia.

In June, 1860, he married Harriet Louise Hinckle, daughter of William Hinckle and Elizabeth Height.

As a young man, Mr. Smith was associated with several leading houses in the drygoods trade, later becoming a member of the firm of Alfred Slade \& Company and again of Slade, Smith \& Company until its dissolution. For several years he was a special partner with the firm of Lewis Wharton \& Co., until he retired in 1867.

When The Union League was organized, he was one of the first members of that club and in addition was on its Board of Directors from an early period until his death, at which time he was the senior Vice-President.

His son, W. Hinckle Smith, is now a member of the Board of Trustees and Treasurer of the Fairmount Park Art Association.

Joseph Frailey Smith was a director of numerous corporations, his most active interest, at the time of his death, being in connection with the building of the Northern Pacific Railroad, his death having been preceded by an extensive trip over its properties only a few weeks before. 


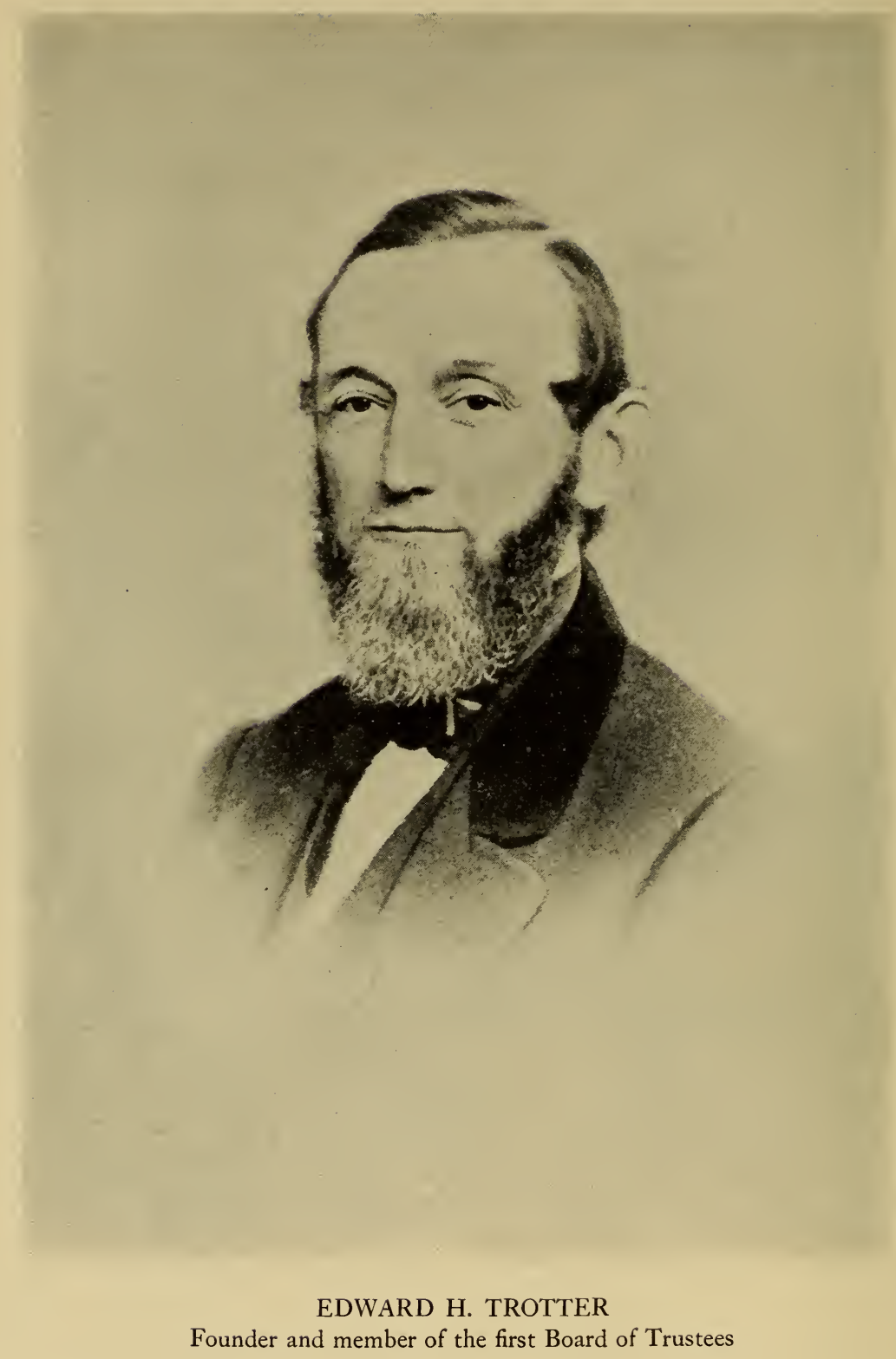

Founder and member of the first Board of Trustees 


\section{EDWARD HOUGH TROTTER}

\section{Founder and Member of the First Board of Trustees}

Edward Hough Trotter was born in Philadelphia November 27, 1814.

His ancestors were of Colonial stock, William Trotter having settled in Elizabeth, New Jersey, in 1666; his name was given to a bridge in the northern part of the town plot and his name also appears in the list of those who subscribed to "The Oath of A Leagence and Fidelity taken by the inhabitants of Elizabeth Town and the Jurisdiction thereof beginning with the 19th February 1665." The historian of the period suggests that a Trotter mounted his horse and rode to New Castle to greet the new Governor (William Penn) and Proprietor, when he descended from "The Welcome" October 28, 1682. One of his ancestors was Joseph Trotter, member of the Pennsylvania Legislature 1739-1755.

Edward Hough Trotter was a member of the firm of Nathan Trotter \& Co., dealers in metals; he was a director of the Lehigh Valley Railroad Co. and chairman of its Finance Committee and took an active part in public affairs. He became a member of The Union League in 1863. 1872.

Mr. Trotter died at his home in Chestnut Hill, May 3,

The notice of the death of his ancestor, William Trotter, in 1749 , is so applicable, that it is here repeated.

"In his life and conversation he was grave, yet innocently cheerful and strictly just in his dealings, also a lover and a promoter of peace, unity and brotherly love amongst friends, of which he himself was a good pattern. He was generally beloved during his life and at his death left a good savour." 


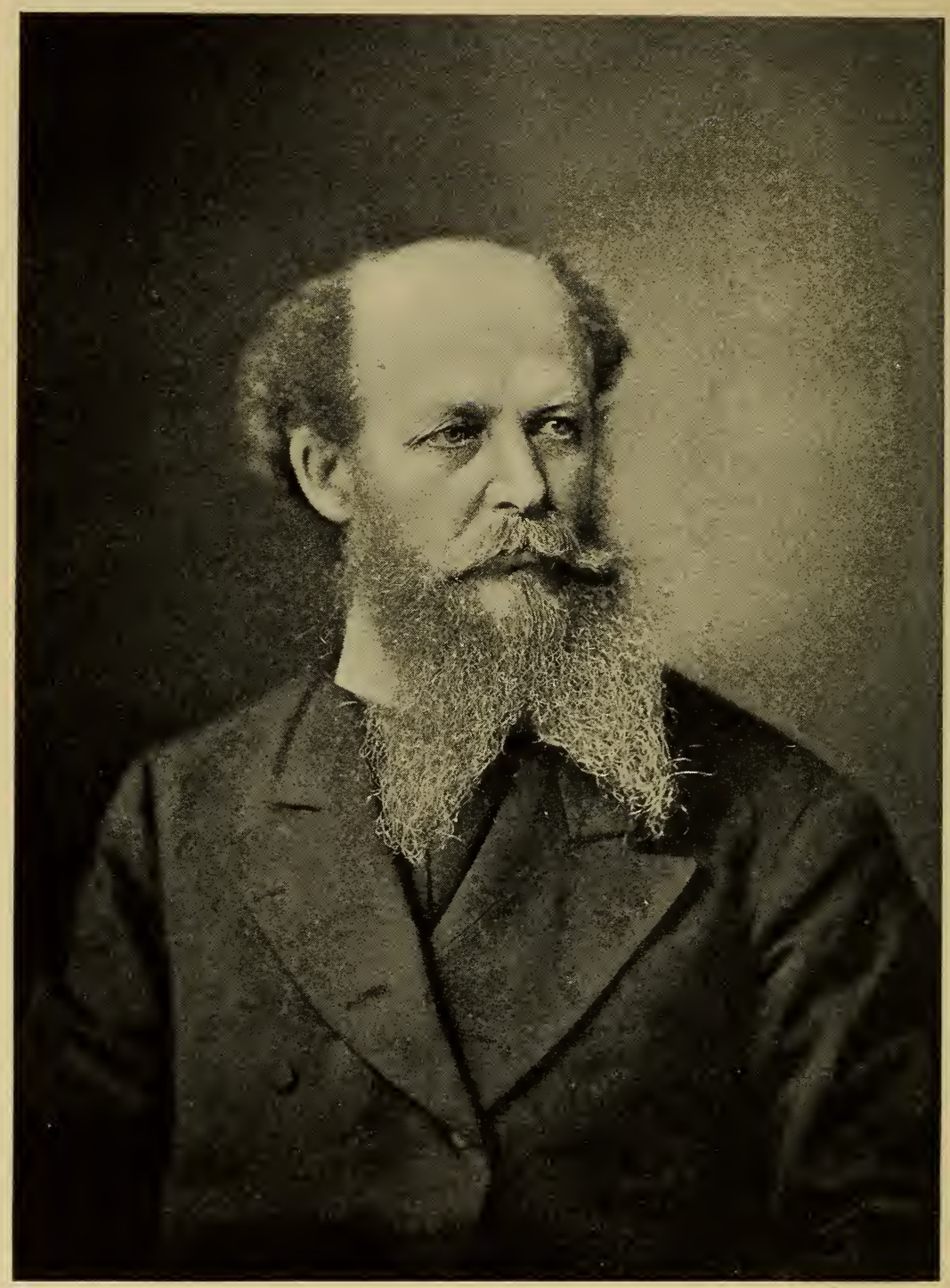

SAMUEL S. WHITE

Founder and member of the first Board of Trustees 


\section{SAMUEL S. WHITE}

\section{Founder and Member of the First Board of Trustees}

Samuel Stockton White was born at Hulmeville, Bucks County, Pennsylvania, June 19, 1822. At the age of sixteen he was indentured to his uncle, Samuel W. Stockton (an early manufacturer of porcelain teeth). Shortly after attaining his majority Mr. White, in 1844, began business for himself at the corner of Seventh and Race Streets, Philadelphia, practicing dentistry on the first floor and conducting in the garret, his infant industry, the making of mineral (porcelain) teeth. A skilful mold-cutter, he individualized the forms of the various teeth, as they had never been before. This great advance gained immediate recognition and the demand became so insistent, as to cause him to relinquish the practice of dentistry to devote himself thereafter entirely to the problems of manufacturing.

The first public recognition of Dr. White's efforts was a testimonial signed by many leading dentists throughout the country, recording the superiority of the porcelain teeth of his make, which was presented in January, 1846. In 1853 the Philadelphia College of Dental Surgery conferred upon him the honorary degree of Doctor of Dental Surgery, "as a testimonial of our appreciation of the value of services rendered to the dental profession in the manufacture and improvement of mineral teeth."

Steadfast adherence to his determination to make only the best that could be produced led to equal success in the other departments of his manufacture, the development of which proceeded rapidly. Of steel instruments, for example, he produced in 1867, a line so refined in forms, so perfectly adapted to all the requirements that they were at once acclaimed the finest the world of dentistry had ever seen.

Dr. White died December 30,1879, in the fulness of his powers, leaving a heritage whose luster time will not dim.

To the foregoing list of Founders and Members of the original Board of Trustees are added the names of those who have served the Association for a series of years and have aided materially by exceptional qualities to maintain it and to add lustre to its repute. 


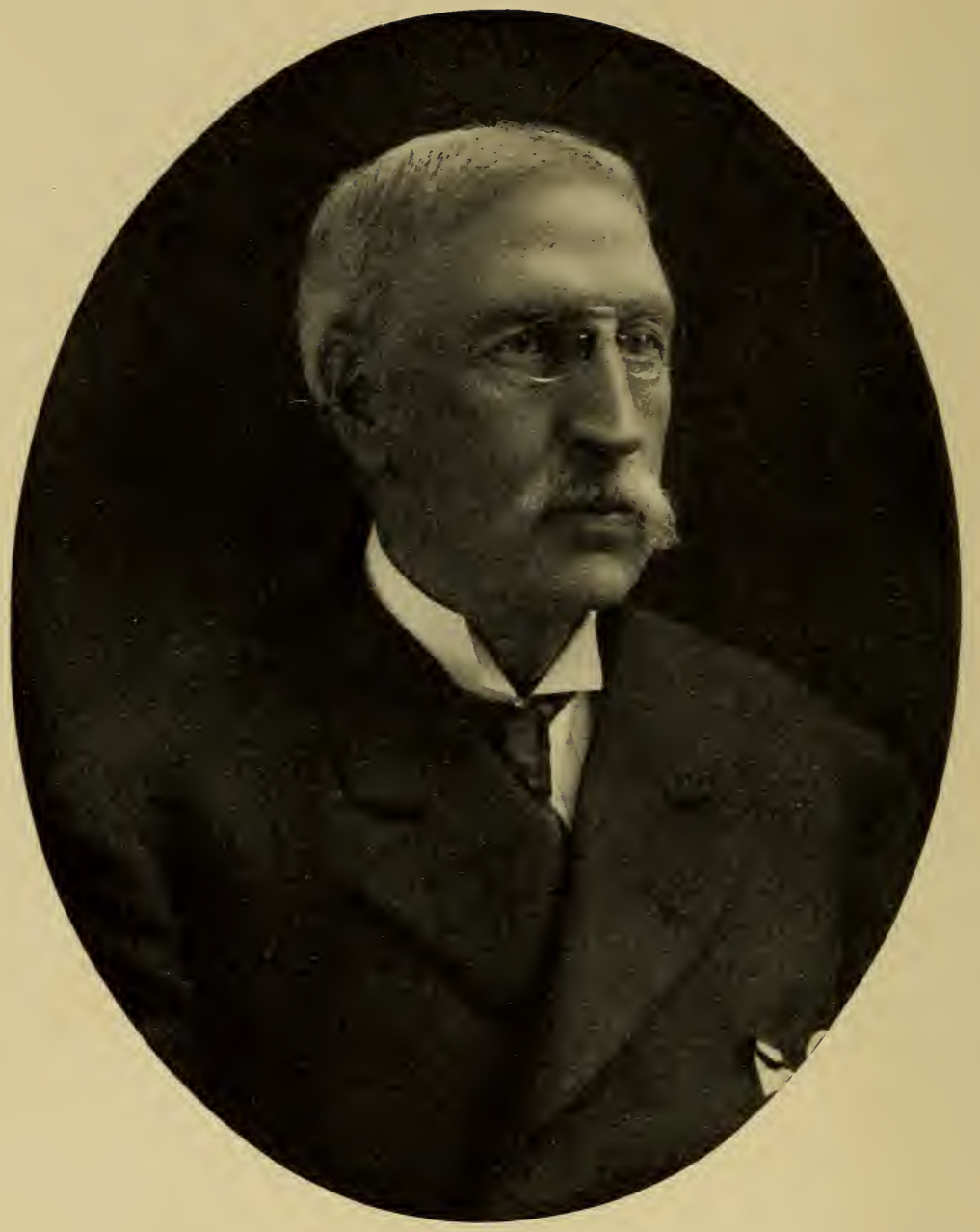

JOHN H. CONVERSE

Died May 3, 1910.

President of the Fairmount Park Art Association, 189t-1900, 1904-1908; Vice-President, 1909-1910. 


\section{JOHN H. CONVERSE}

John H. Converse was born in Burlington, Vermont, December 2, 1840, the fourth of the seven children of the Rev. John Kendrick and Sarah (Allen) Converse.

When a youth he studied telegraphy and was one of the first operators in Vermont able to take a message from the sound alone.

At fourteen years of age he had his first employment as telegraph operator at Essex Junction, on what is now the Central Vermont Railroad. Later, in 1857, he entered the University of Vermont and was graduated in the class of 1861.

Entering journalism in his native town, he became connected with the leading paper and through the writing of editorials and also the work of printing and issuing the paper he acquired a wide practical experience of great value.

Through one of his college mates he came to the notice of Norman Williams, a noted lawyer of Chicago, whose brother, Dr. Edward H. Williams, was superintendent of the Galena Division of the Chicago \& Northwestern Railroad, and to the latter $\mathrm{Mr}$. Converse was recommended as an efficient clerk. At this time Dr. Williams attracted the attention of John Edgar Thomson, then President of the Pennsylvania Railroad, who tendered him the position of General Superintendent at Altoona, which was accepted, and $\mathrm{Mr}$. Converse accompanied him. Later Dr. Williams resigned from the Railroad Company and, on his acquiring an interest in the Baldwin Locomotive Works, Mr. Converse accompanied him to Philadelphia and in 1873 became a member of the firm, being in charge of the commercial business of the Works.

In business conferences or in meetings of the many business or charitable boards with which he was connected he would sit quietly listening, saying little, so long as matters were going as he thought they should; but whenever they became tangled he would by a few words indicate a solution so logical and so obviously correct that there would then appear to be no other course open, and all conflicting interests would disappear.

Another and important phase of his character was his deep interest in evangelistic religion, which originated during his residence in Chicago, when Dwight L. Moody conducted services in a passenger car in the yards of the Northwestern 
Road. Throughout his entire career he was deeply impressed by the sanctity of religious faith and took every opportunity of encouraging and supporting in generous fashion every movement in that direction.

Among the many positions of trust and honor, which he filled at various times, were the following: trustee of the Presbyterian Hospital and Secretary of its Board of Trustees; trustee of Princeton Theological Seminary and of the University of Vermont; director of the Philadelphia National Bank, Franklin National Bank, Philadelphia Saving Fund, Real Estate Trust Co., Philadelphia Trust, Safe Deposit and Insurance Co., Pennsylvania Academy of the Fine Arts; President of the New England Society of Pennsylvania, Presbyterian Social Union, Board of Trustees Bryn Mawr Presbyterian Church, Manufacturers' Club and Fairmount Park Art Association; member of the Board of City Trusts and in that capacity a trustee of Girard College; member of the Philadelphia Board of Education; member of the American Philosophical Society, Presbyterian Board of Publication and Sabbath School Work, Contemporary Club, Union League, University Club, Art Club, Engineers' Club, Pennsylvania Society Sons of the Revolution, Vermont Society Sons of American Revolution, Order of Founders and Patriots, and Treasurer of the Christian League. He was governor of the Society of Colonial Wars, Vermont, to membership in which he was entitled because of his being a great-grandson of Corporal Enoch Allen (1744-1789).

For many years his benefactions were boundless; his office was daily sought by college presidents, missionaries, charitable workers and all who were interested in philanthropic and civic movements, seeking his advice and his pecuniary aid.

Mr. Converse was a member of the Fairmount Park Art Association for twenty-eight years, was president for eleven years, 1894 to 1900 and 1904 to 1909 , and Vice-President from his declining the presidency in 1909 until his death on May 3,1910 , and during all this time he took a sincere interest in its affairs, besides being a liberal contributor to the various projects for adding to the attractiveness of the Park. The Parkway Association, of which Mr. Converse was President, issued a quarto pamphlet with illustrations of the proposed improvements in connection with the suggested Parkway, demonstrating some of the leading features in 
similar enlargements in leading cities of the world. The introductory plea by Hon. James M. Beck was a powerful argument for the adoption of the plan and its complete presentation by Albert Kelsey, the Secretary of the Parkway Association, produced a marked effect on public opinion.

It is believed that the entire expense of this particular movement was defrayed by $\mathrm{Mr}$. Converse personally. All honor to the few survivors and to the memory of those who have passed beyond, whose earnest and unselfish endeavors for the betterment of our City are now about to be realized. His advice in the financial affairs of the Association was greatly valued. No one could know him without appreciating his simple, quiet, but strong qualities as a man. As a citizen he enjoyed the respect of the entire community in an unusual degree and, while declining the civic positions which were offered to him, he was never found wanting in courage, in liberality, in patriotism, in all the affairs which minister to its honor and distinction. 


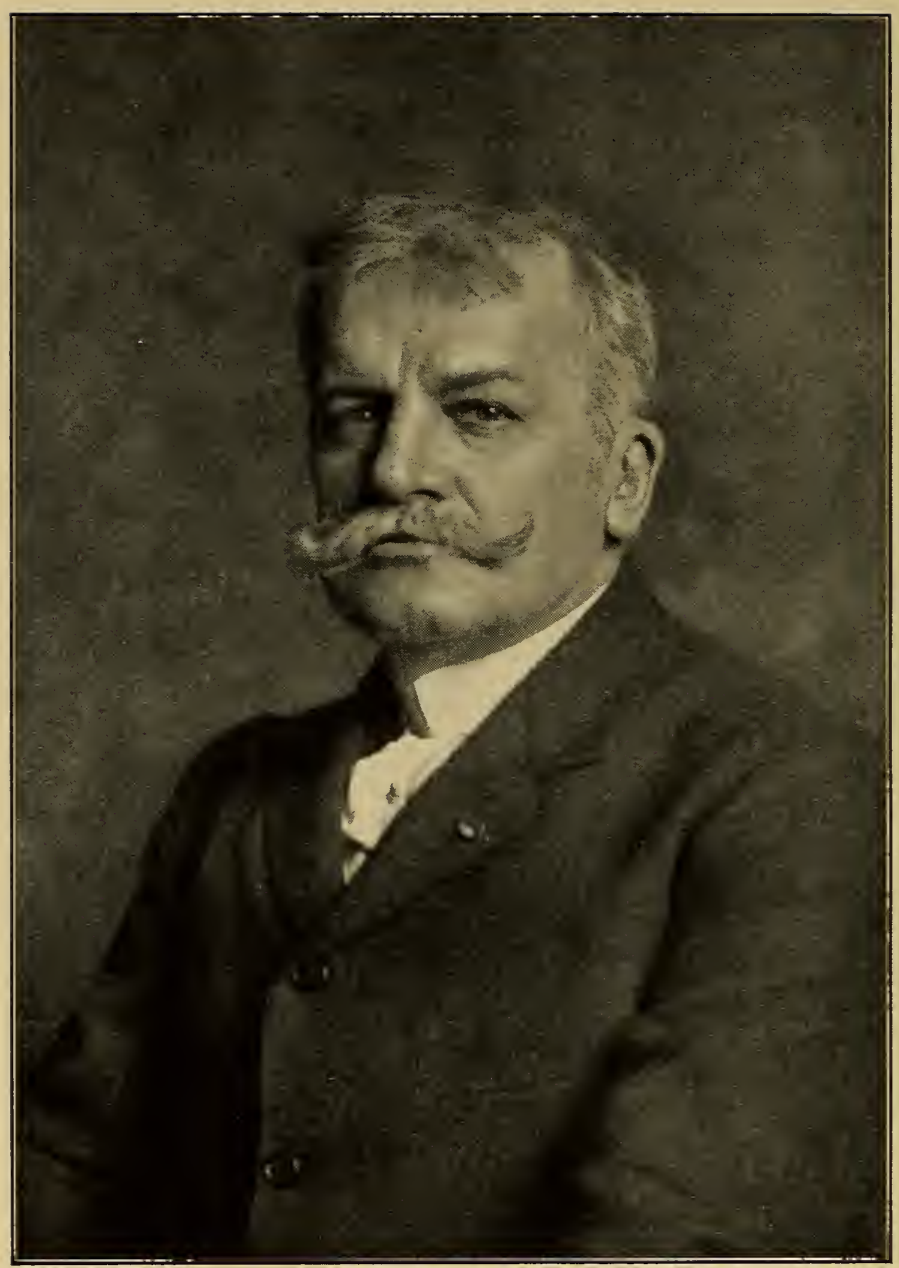

CHARLES E. DANA

Vice-President, 1900-1914 


\section{CHARLES EDMUND DANA \\ Vice-President of the Association}

Charles E. Dana was born January 18, 1843, at WilkesBarre, Pennsylvania, and died February 1, 1914, in Philadelphia.

Mr. Dana was the great-grandson of Judge Peters of Belmont, Fairmount Park, where both Lafayette and Washington were frequent visitors, as were many of the notable men of the day.

Professor Dana was educated at schools in Philadelphia, the Royal Academy in Dresden and the Royal Academy in Munich; at Union University, Schenectady, N. Y., for Civil Engineering, graduating in the class of 1865; also at the Pennsylvania Academy of the Fine Arts, Philadelphia; and at the Atelier Luminais, Paris, for painting. He was Professor of Art in the School of Architecture, University of Pennsylvania, for ten years; also a Trustee of the Pennsylvania Museum and School of Industrial Art, where he gave lessons in painting for several years.

For some time Professor Dana was Vice-President of the Pennsylvania Institution for the Deaf and Dumb, Mount Airy; President of The Numismatic and Antiquarian Society of Philadelphia; for ten years President of the Fellowship of the Pennsylvania Academy of the Fine Arts and of the Philadelphia Water Color Club; President and Vice-President of the Contemporary Club and a Director of the Library Company of Philadelphia. He was a member of the Loyal Legion, Aztec Club, Pennsylvania Society of Sons of the Revolution, Rittenhouse Club, Art Club, Philadelphia Barge Club, and Franklin Inn Club, and a member of the American Philosophical Society, Vice-President of the Fairmount Park Art Association and Secretary of the Shakespeare Society.

Mr. Dana married Miss Emilie Hollenback Woodbury, daughter of Peter Trask Woodbury, and is survived by his widow and a daughter, Miss Millicent Woodbury Dana.

A feature in his career that especially commended itself to public-spirited citizens was his deep interest in many activities of positive civic value; it is rare that a man of his accomplishments is willing to give so much time and energy to public service, and his devotion to these matters should be noted with full appreciation. 


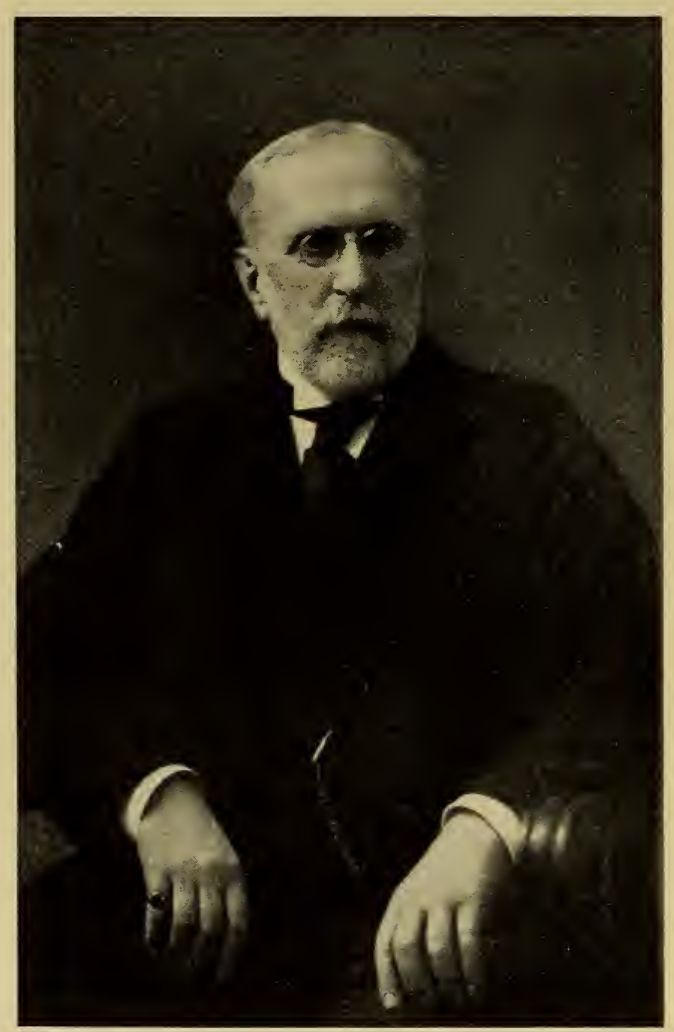

IOHN T. MORRIS

Vice-President, 1909-1915 


\section{JOHN THOMPSON MORRIS}

\section{Vice-President of the Association}

The Morris family is of ancient lineage and members have been distinguished in every generation, especially in Philadelphia.

Coming from England in 1682 they brought their steadfast faith in the Society of Friends, continued to the present day.

Captain Samuel Morris organized the First Troop Philadelphia City Cavalry, which played a conspicuous part in the Revolutionary War, as also in all subsequent disturbances when called upon to act.

John T. Morris was a graduate of Haverford College and later became a member of its Board of Managers. He succeeded his father in the I. P. Morris Engine Building Co. which was finally disposed of to the Cramp Shipbuilding Co., the properties adjoining and the Morris section being required for a necessary expansion of the Cramp interests.

Mr. Morris was a manager of the Philadelphia Saving Fund; Chairman of the Philadelphia Contributionship for the Insurance of Houses; a member of the Board of the Franklin Institute and of the Pennsylvania Museum and School of Industrial Art; former president of the Deaf and Dumb Institution at Mount Airy; Councillor of the Historical Society of Pennsylvania; Overseer of the Public School founded by William Penn, now styled "The Penn Charter School"; and Vice-President of the Fairmount Park Art Association, in which he was deeply interested, giving much time and thought to its development.

His estate at Chestnut Hill, created by him in a few years out of a barren rocky hill, is one of the most beautiful parks in suburban Philadelphia; here he lived in summer with his sister, Miss Lydia T. Morris, dispensing boundless hospitality.

He had a fine presence and a winning personality, to which should be added a generous disposition aiding in every good work brought to his attention. 


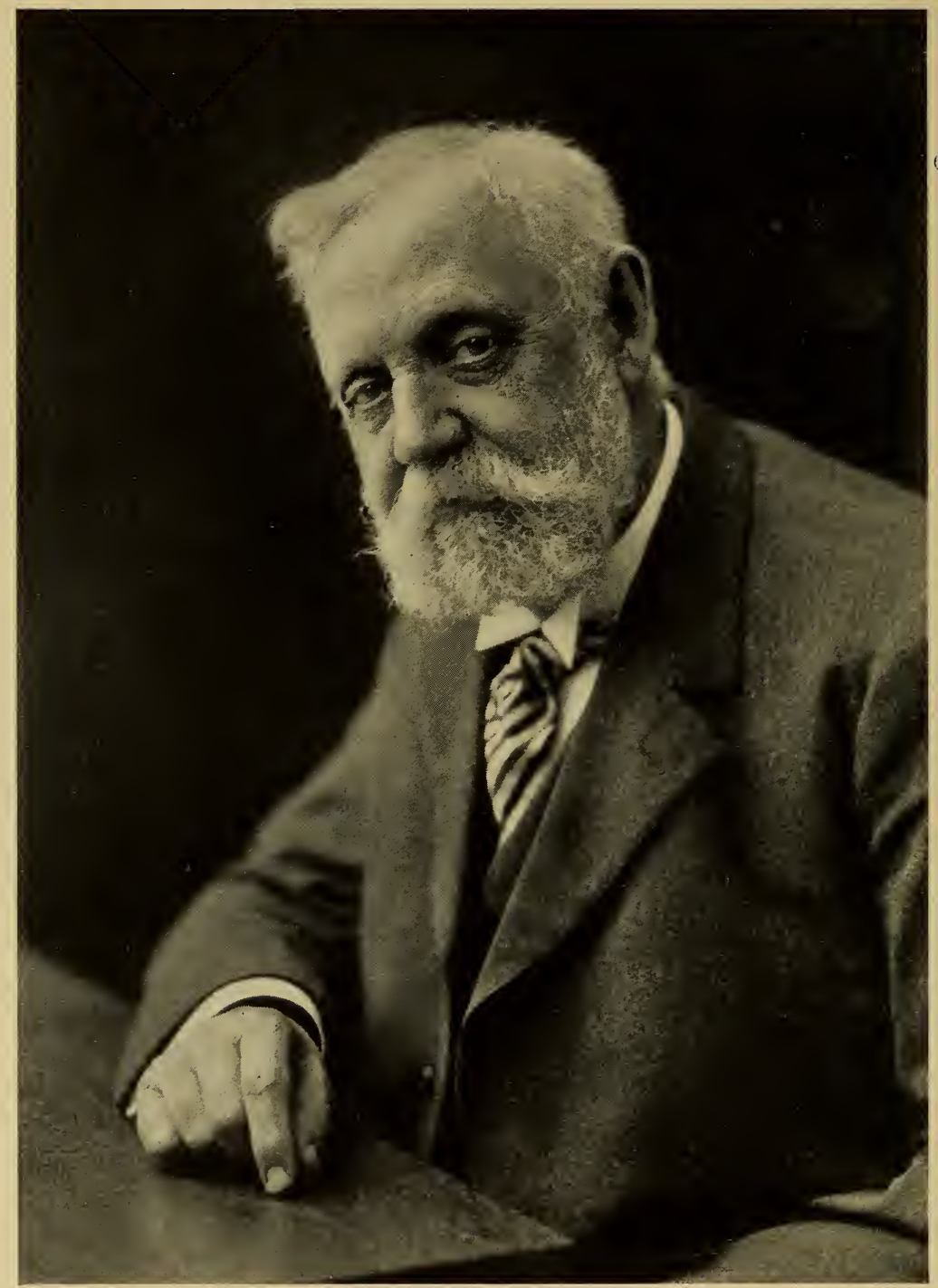

LESLIE W. MILLER, LL..D.

Secretary, 1900-1920 


\section{LESLIE W. MILLER}

\section{Trustee and Secretary of the Association}

Leslie William Miller was born in Brattleboro, Vermont, August 5, 1848, and was educated in the public schools of his native town and at the Massachusetts Normal Art School at Boston.

At first engaged as teacher and also as portrait painter, he was invited to Philadelphia in 1880 to become the Principal of the Pennsylvania Museum and School of Industrial Art, recently organized as an outcome of the Centennial Exhibition of 1876. It then had a total attendance of 73 students; today it has 40 instructors and over 1300 students.

In June, 1920, the degree of Doctor of Fine Arts was conferred on Mr. Miller by the University of Pennsylvania and that of Doctor of Laws by Temple University, the former especially an evidence of the purpose and spirit of the University to recognize the Fine Arts and to co-operate with the Pennsylvania Academy of the Fine Arts, the new Municipal Museum and the School of Industrial Art, to make the approach to Fairmount Park an Art centre unrivalled by any other in this country.

Mr. Miller was a member of the Art Jury of Philadelphia from its inception and Secretary and then Vice-President of it; he was Vice-President of the Art Club of Philadelphia; member of the Boston Art Club and of the American Philosophical Society.

Mr. Miller is a fluent speaker and has delighted many audiences with his graphic descriptions covering a wide range of topics. His pen has been freely used to encourage art in his adopted city and his advocacy of improved municipal conditions, especially the physical regeneration of the banks of the Schuylkill, will have an enduring influence upon the community.

His work published by the Scribners entitled "Essentials of Perspective," is widely recognized as an authority in architectural circles.

In 1874 Mr. Miller married Sarah Maria Persons; they have two sons, Percy and Arthur, both of whom took an active interest in our communal life, thus sustaining the example so well put forth by their honored father. 
At the closing stated meeting of the Trustees held April 9, 1920, the following was adopted:

"The Board of Trustees of the Fairmount Park Art Association has learned with exceeding regret that Mr. Leslie W. Miller has indicated his purpose to leave Philadelphia for his home in New England and that necessarily he will have to yield his interests in this Association.

"Imbued with the love of art, especially as identified with civic improvement, he became a member of this association in 1884 and a trustee in 1895. As Chairman of the Committee on Works of Art, he showed the mature judgment so essential to the conduct of the affairs of the most important committee in the organization. Later, after earnest solicitation from the board, Mr. Miller accepted the secretaryship of the Association, and from 1900 to the present time, twenty years, he has virtually been the executive manager, conducting its various activities with a skill and ability that has brought the Association to the prominent position it now holds. Actuated always by the highest motives of altruism, his untiring interest in civic betterment, both artistic and practical, has been a potent factor in the life of the city, and it is the purpose of the Board to declare the debt of gratitude that is due him for his energy and skill. In parting with Mr. Leslie W. Miller, not only is the Association losing an important officer, but the city of Philadelphia is being deprived of the services of one of its most distinguished citizens, creating a void most difficult to fill. And to each member of the Board it will be a personal loss, since in all these years there has been a unanimity of regard and esteem engendered by Mr. Miller's rare qualities of mind and heart.

"Of his many activities in other directions it is for others to speak, but the trustees may apply the comment of old, when a great leader was to be commended:

" "And he hath put in his heart that he may teach, he hath filled him with wisdom of heart, to work all manner of work, of the engraver and of the cunning workman and of the embroiderer, in blue and in purple, in scarlet and in fine linen, and of the weaver, even of them that do any work and of those that devise works of art." 
Charles J. Cohen, Esq.,

President,

Fairmount Park Art Association,

Philadelphia.

My dear Mr. President:-

With many regrets that it is impossible for me to be present in the body to participate in the celebration of the fiftieth anniversary of the Fairmount Park Art Association, I send my felicitations on the honorable results already achieved and the promise of an ever extending influence for good to the City we all love so well, that will be so fittingly proclaimed by our eloquent friend, Mr. Beck, on this auspicious occasion.

The list of Philadelphia's achievements, and of the men whose consecrated efforts have added such lustre to her name, is a long and honorable one; the City has been first in many things, but in nothing more conspicuously and honorably than in the work of upholding civic beauty as an exponent of civic dignity and duty, in which the Fairmount Park Art Association is easily first. It has a right to be proud of what it has accomplished, and it does well to celebrate its achievements, and to honor the memory of the men, and women, who united in the generous purpose which its founding represented, and in the support which has been accorded it through all the years that it has known.

May the name of its single-hearted and public-spirited founder, Col. Charles H. Howell, be held in increasing honor as the years go by, and may the roll of generous supporters of the great civic principle which he was foremost in advocating be lengthened and enlarged forever.

Yours very sincerely,

(Signed) LESLIE W. MILLER. 


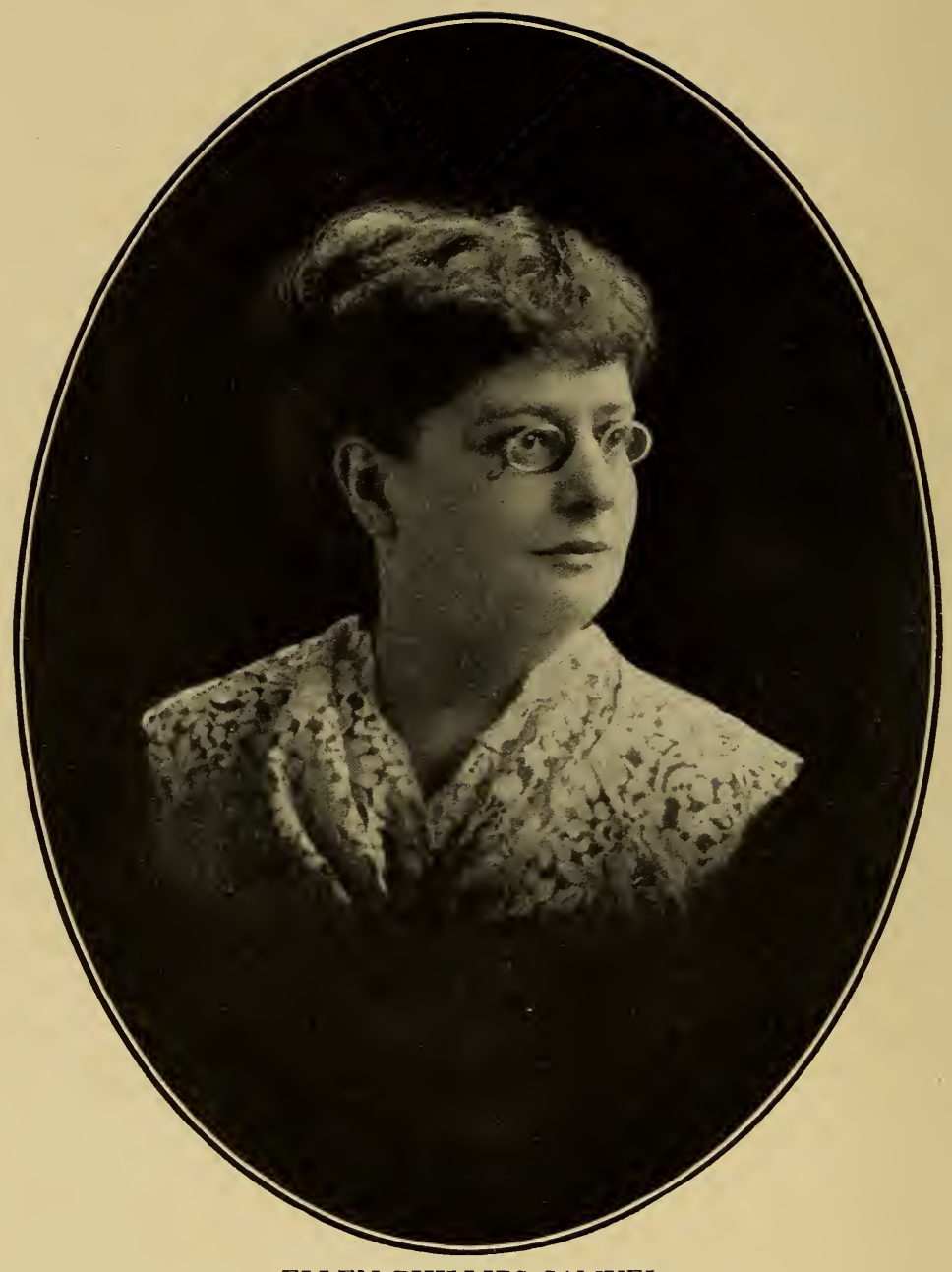

ELLEN PHILLIPS SAMUEL

Who bequeathed her entire residuary estate upward of $\$ 765,000.00$ to the Fairmount Park Art Association 


\section{ELLEN PHILLIPS SAMUEL}

\section{Benefactor of the Association}

Mrs. Ellen Phillips Samuel, the youngest daughter of the late Jonas Altamont Phillips, a distinguished member of the Philadelphia bar, was born in Philadelphia March 8, 1849. Her uncle, the Hon. Henry M. Phillips, is well remembered as one of the most public-spirited men of his generation. He was a distinguished member of the bar of Philadelphia, a member of the United States House of Representatives and of the Board of City Trusts, of which he was President. He was President of the American Academy of Music and President of the Commissioners of Fairmount Park, and the generous benefactions, which bear his name in the various scientific, patriotic and philanthropic societies of Philadelphia, give eloquent testimony to his deep interest in everything that concerned the public welfare and the earnestness of his efforts to promote the higher life of the community.

Mrs. Samuel had shown a deep interest in the welfare of the Fairmount Park Art Association for many years and her aunt, the late Miss Emily Phillips, was a liberal subscriber in 1895 to the Perpetual Fund of the Park Branch.

Mrs. Samuel's interest in the work of the Fairmount Park Art Association was shared by her husband, a fellow member, and the project which she had so much at heart owes much to his sympathetic and cordial co-operation.

By the will of Mrs. Samuel, who died in Philadelphia October 1, 1913, the Association becomes the residuary legatee of her estate conservatively estimated at seven hundred and sixty-five thousand dollars, the income to be used primarily for the erection of a series of statues on the east bank of the Schuylkill river below the Girard Avenue Bridge. Through the generosity of her husband, J. Bunford Samuel, Esq., the provision of the will has been anticipated through his action in giving the first statue now placed on the East River Drive above the Boat Houses. The statue is a splendid representation in bronze of the first settler in America, Thorfinn Karlsefni, the Norseman; the design was the work of Einar Jonsson, a noted Icelandic sculptor, who accepted Mr. Samuel's invitation to visit America and was his guest in Philadelphia while modeling and completing the statue. In due 
time other statues "emblematic of the history of America" will follow, and upon their completion the income arising from this munificent fund is authorized "to be spent in buying statuary and fountains to decorate the Park."

This bequest, it may be stated, is one of the two largest that have ever been made for a similar purpose in this country and the Trustees have gratefully accepted the responsibility of carrying out the wishes of the testatrix. 


\section{Works of Art}

Contributed by the Fairmount Park Art Association to Fairmount Park

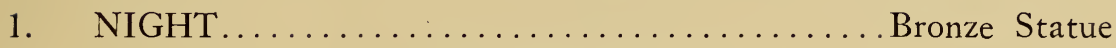
BY EDWARD STAUCH

2. HUDSON BAY WOLVES ................... Bronze Group BY EDWARD KEMEYS

3. IL PENSEROSO .................................. Statue BY MOZIER

4. THE AMBUSCADE ..................... Oil Painting FIGURES BY BARON WAPPERS. LANDSCAPE BY KOEKKOEK

5. CHALK AND HIS FRIENDS .............. Oil Painting BY NEWBOLD H. TROTTER

6. THE DYING LIONESS.................. Bronze Group BY WILHELM WOLFF

7. DIANA BORGHESE.................. Terra Cotta Statue

8. TAM O'SHANTER.... Group of Four Figures in Red Sandstone BY THOM

9. DRINKING FOUNTAIN .................... Granite

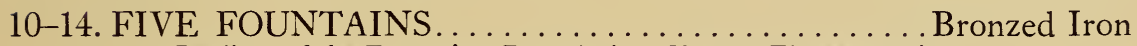
Replicas of the Fountains, Rond Point, Champs Elysées, Paris

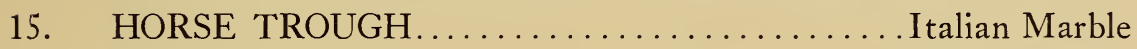

16. GRAND FOUNTAIN .................... Bronzed Iron

17. FOUNTAIN OF “ORESTES AND PYLADES”...Bronze Group BY CARL STEINHAEUSER

18. SILENUS AND THE INFANT BACCHUS ........... Bronze

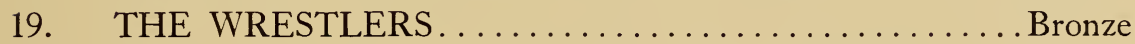

20. FACE AND HANDS OF ABRAHAM LINCOLN . ..... Bronze 21-22. FLORENTINE LIONS . . . . . . . . . . . . . . Bronze

23. EQUESTRIAN STATUE OF MAJOR-GENERAL GEORGE

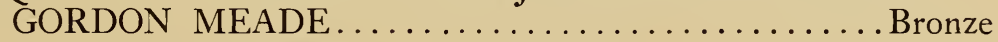
BY ALEXANDER MILNE CALDER

24. STONE AGE IN AMERICA ............................ BY JOHN J. BOYLE 
26. EQUESTRIAN STATUE OF JEANNE D'ARC........ Bronze BY FREMIET

27. EQUESTRIAN GROUP, “LION FIGHTER”. .......... Bronze BY ALBERT WOLFF

Original plaster cast purchased by the Association

28. HAMLET AND OPHELIA................. Oil Painting BY GEORGE W. PETTIT

29. BUST OF JAMES A. GARFIELD, PRESIDENT OF THE UNITED STATES, AND ALLEGORICAL FIGURE Bronze By AUgustus ST. GAUDENS

30. EQUESTRIAN STATUE OF GENERAL U. S. GRANT. Bronze BY DANIEL, CHESTER FRENCH AND EDWARD C. POTTER Pedestal designed by Frank Miles Day and Brother

31. BRONZE SPANISH CANNON, "MILTIADES”.... Date, 1743

32. BRONZE SPANISH CANNON, "SEMIRAMIS"... . Date, 1737

33. BRONZE SPANISH MORTAR.............. Date, 1731

34. EQUESTRIAN STATUE, “THE MEDICINE MAN”... Bronze BY CYRUS E. DALLIN

35. MONUMENTAL MEMORIAL TO PENNSYLVANIA'S MILITARY AND NAVAL OFFICERS DISTINGUISHED FOR GALLANTRY IN THE CIVIL WAR OF THE UNITED STATES, 1861-1865

The statuary in bronze comprises the following:

A. Colossal equestrian statue of Major-General Hancock, by J. Q. A. Ward.

B. Colossal equestrian statue of Major-General McClellan, by Edward C. Potter.

C. Colossal figure of Major-General Meade, by Daniel Chester French.

D. Colossal figure of Major-General Reynolds, by Charles Grafly.

E. Colossal figure of Richard Smith, by Herbert Adams.

Eight colossal busts as follows:

F. Admiral Porter, by Charles Grafly.

G. Major-General Hartranft, by A. Stirling Calder.

H. Admiral Dahlgren, by George E. Bissell.

I. James H. Windrim, Esq., by Samuel Murray.

J. Major-General S. W. Crawford, by Bessie O. Potter.

K. Governor Curtin, by M. Ezekiel.

L. General James A. Beaver, by Katherine M. Cohen.

M. John B. Gest, Esq., by Charles Grafly.

N. Two Eagles and Globes, by J. Massey Rhind.

36. SUN-DIAL AND MARBLE PEDESTAL

37. JAPANESE TEMPLE-GATE

38. EQUESTRIAN STATUE-“COW-BOY" BY FREDERIC REMINGTON 
39. FOUNTAIN FIGURE-“THE DUCK GIRL”

BY PAUL MANSHIP

40. MEMORIAL TABLET TO HERMANN JOSEPH SCHWARZMANN

Desizner of Memorial Hall

41. MARBLE FIGURE-“DANAID"

BY RAUCH

42. MARBLE FIGURE- "FEEDING THE DOVES"

43. MARBLE FIGURE- "LOVE TRIUMPHANT"

BY R. H. PARK

44. BRONZE- “PENGUINS”

BY ALBERT LAESSLE

45. BRONZE-“'THORFINN KARLSEFNI”

BY EINAR JONSSON

Contributed by the City Branch

1. LION AND SERPENT....................... Bronze BY BARYE

2. DICKENS AND LITTLE NELL.................. Bronze BY F. EDWIN ELWELL

3. STATUE OF MATTHIAS W. BALDWIN ........... Bronze BY HERBERT ADAMS

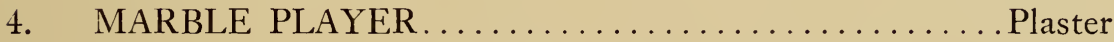
BY A. STIRLING CALDER

5. LARGE MOUNTED PHOTOGRAPHS

Of Grand Fountain, The Medicine Man, Stone Age in America, Lioness Carrying to Her Young a Wild Boar, Jeanne d'Arc, Garfield, Lion and Serpent, The Dying Lioness, Grant, Hudson Bay Wolves, and Meade, have been presented by the Association through the Department of Superintendence and placed in several Public Schools of Philadelphia.

6. MEMORIAL TABLET

Erected at the entrance to the lot on Orianna Street, which was purchased by the Fairmount Park Art Association with funds subscribed for this purpose by several patriotic societies and public-spirited citizens and improved as a means of protecting Carpenters' Hall in 1911.

7. PEDESTAL AND SETTING

For bronze goat, "Billy," by Albert Laessle. Pedestal and exedra designed by Milton B. Medary, Jr. 



\section{WORKS OF ART}

Contributed by or through

THE PARK BRANCH

OF THE ASSOCIATION 


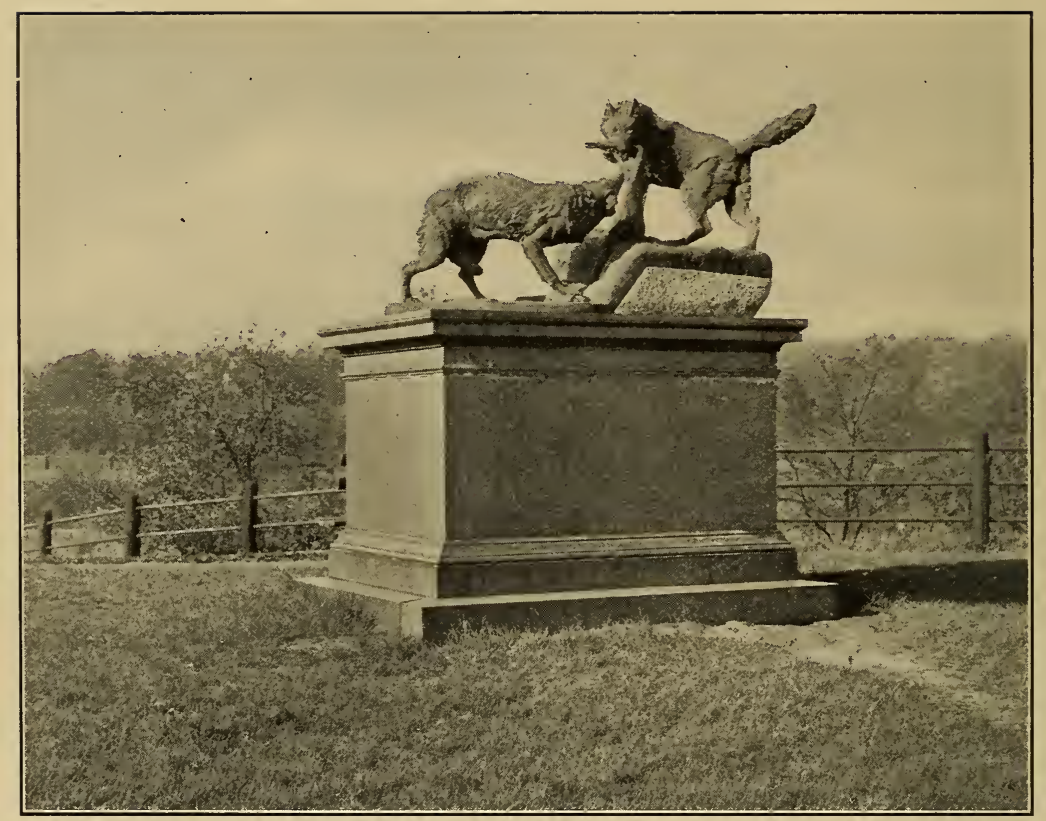

HUDSON BAY WOLVES

Bronze Group by Edward Kemeys

Cast in Philadelphia. Purchased by the Association. Accepted by the Commissioners of Fairmount Park, September 28, 1872. Erected at Lansdowne Entrance, West Park. 


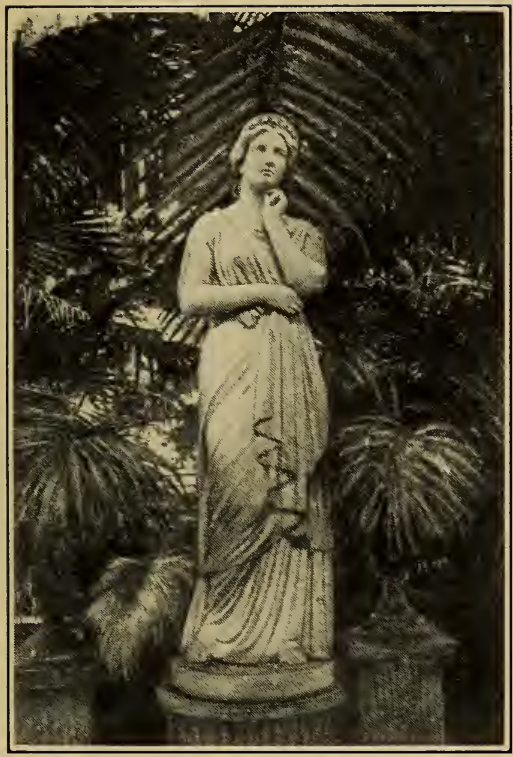

IL PENSEROSO.............Marble Statue BY MOZIER

Purchased by the Association. Accepted by the Commissioners of Fairmount Park, January 10, 1874. Placed in Horticultural Hall, in the Park.

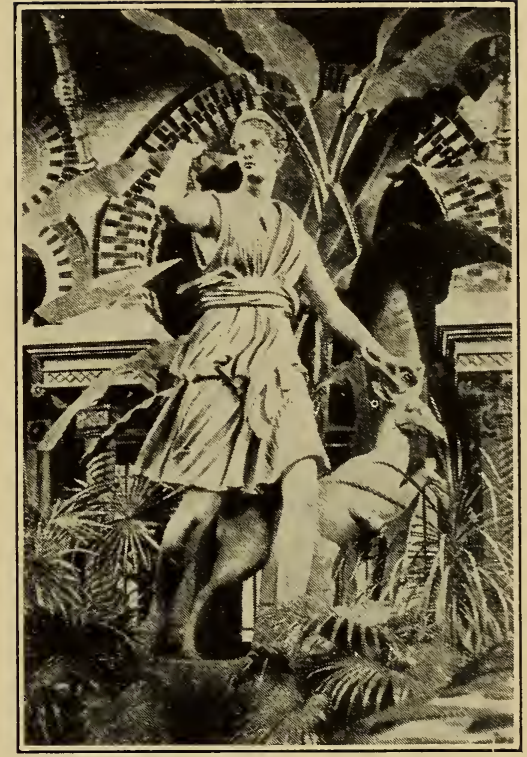

"DIANA BORGHESE".... Terra Cotta Statue Presented to the Association December 29, 1876, by Messrs. H. Doulton \& Co., London, England. Placed in Horticultural Hall, Fairmount Park. 


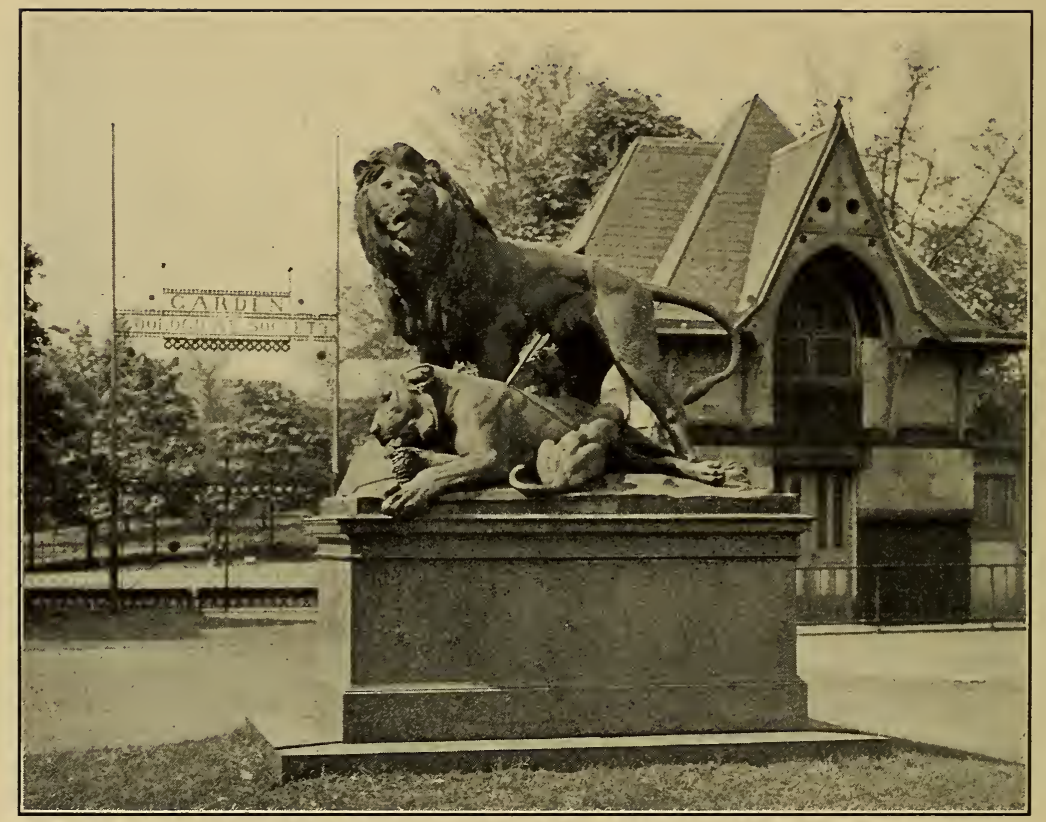

\section{THE DYING LIONESS \\ Bronze Group]}

BY PROF. WILHELM WOLFF, OF BERLIN

Medal, Vienna Exposition, 1873. Cast in Munich. Purchased by the Association. Accepted by the Commissioners of Fairmount Park, December 9, 1876. Placed in the Concourse on Girard Avenue, in front of the Zoological Gardens. 


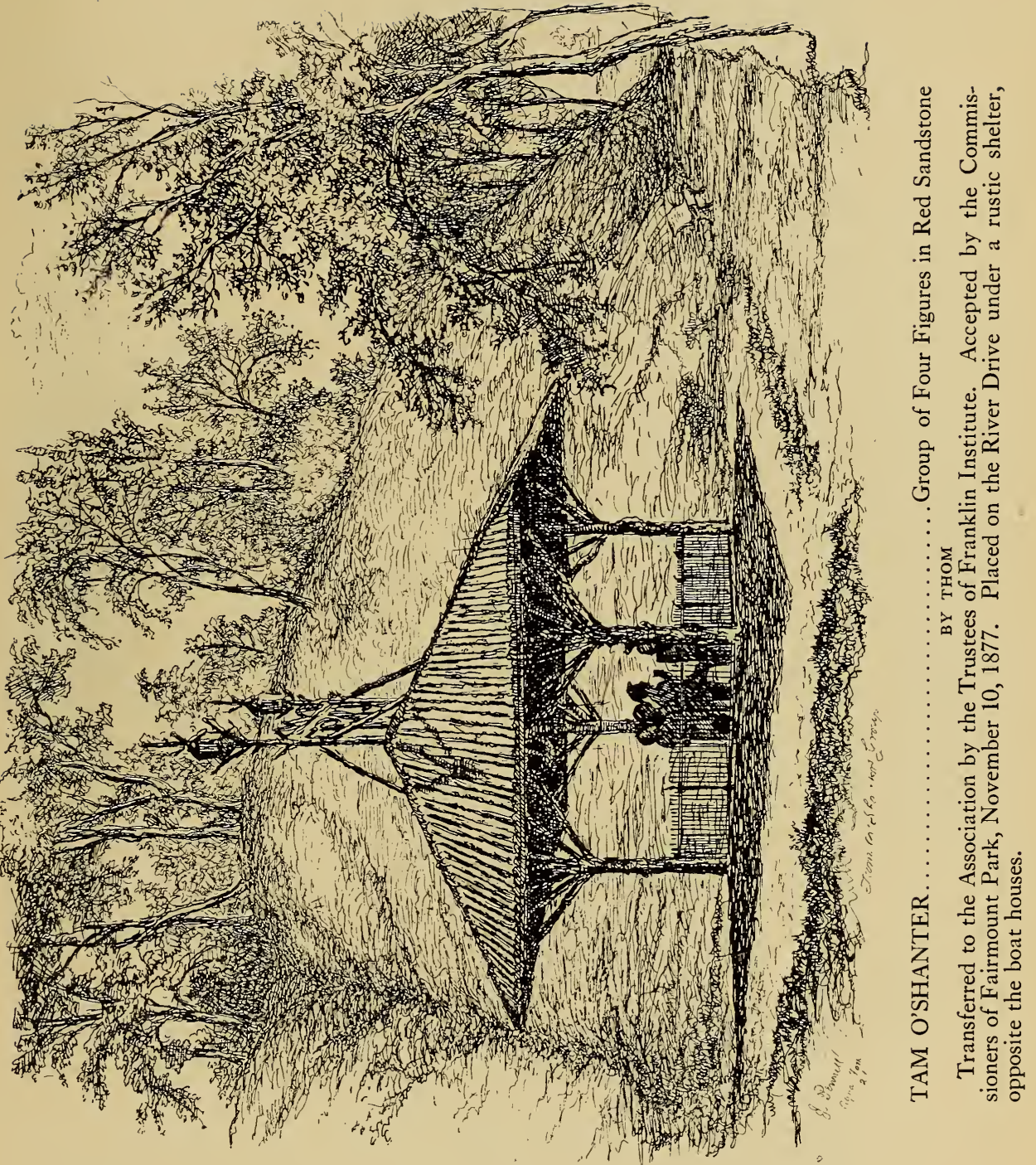




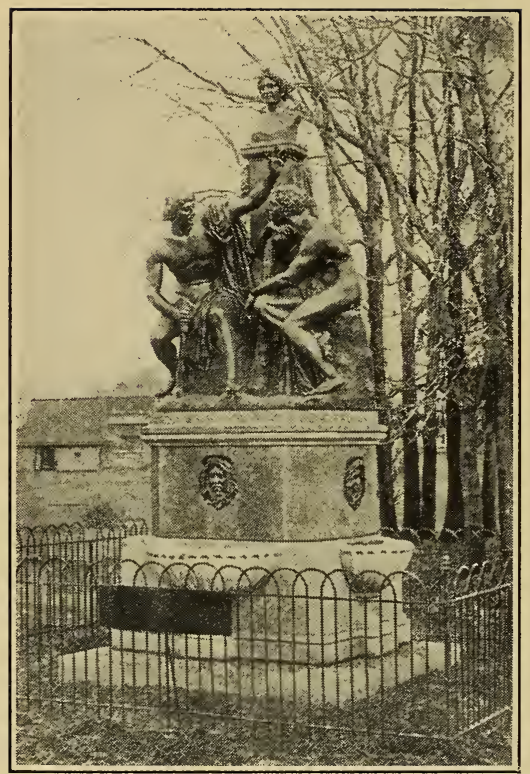

FOUNTAIN OF “ORESTES AND PYLADES” (Bronze Group)

BY CARL STEINHAEUSER, OF CARLSRUHE, GERMANY

Placed near Columbia Avenue entrance to the East Park.

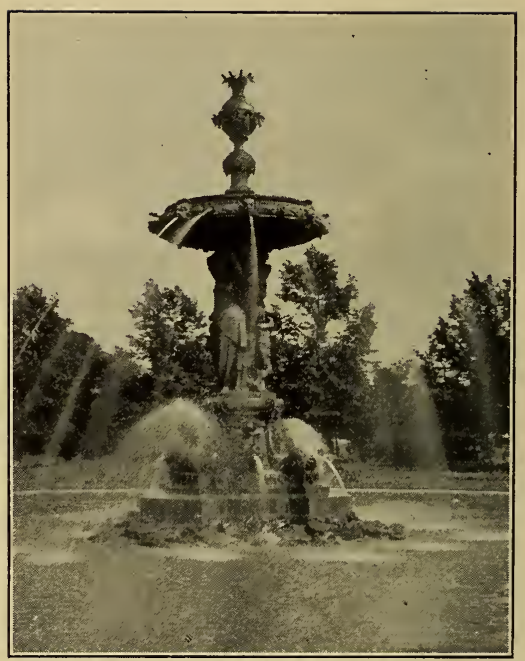

GRAND FOUNTAIN

Bronze Iron, erected in the East Park near the Dauphin street entrance, 1879. 


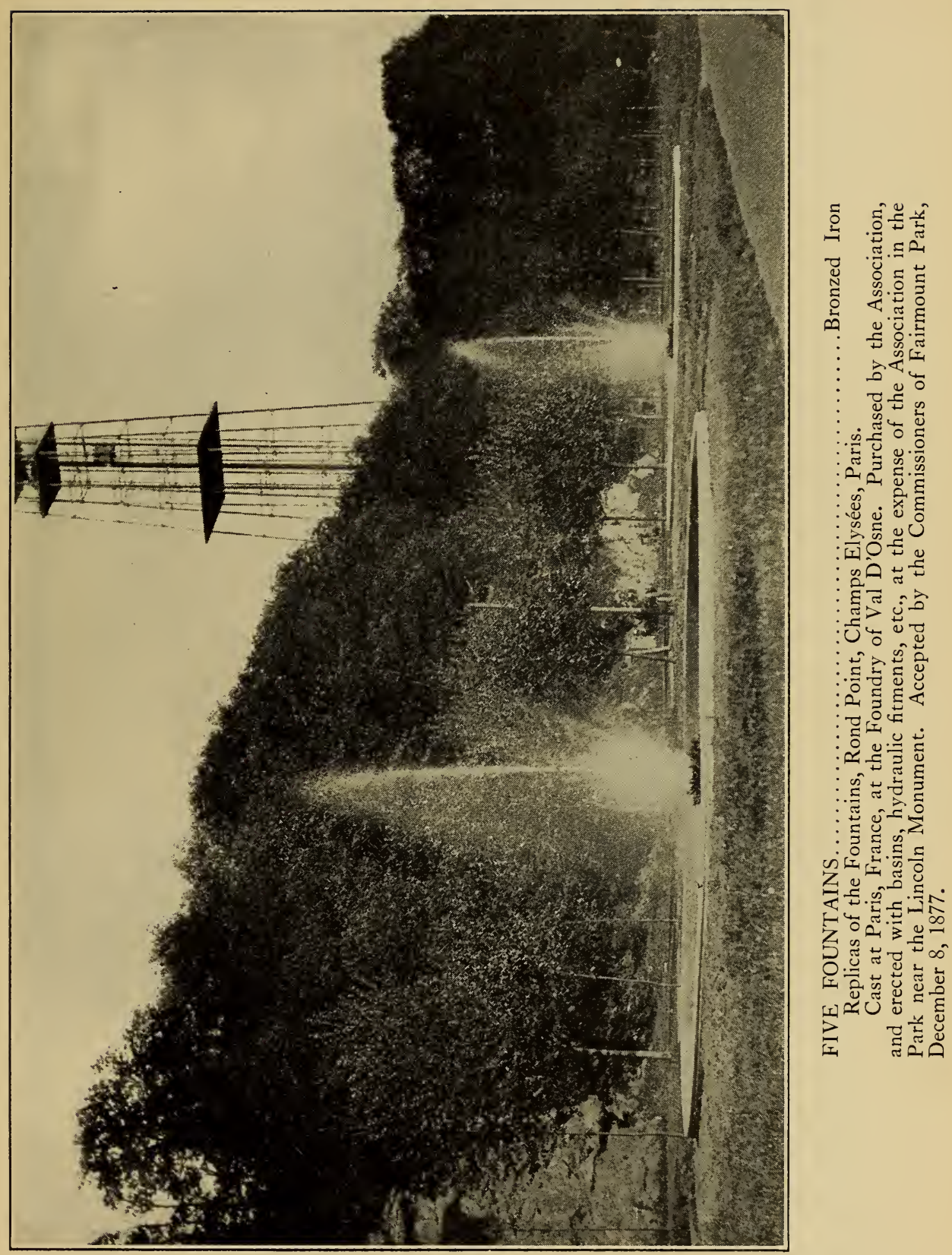




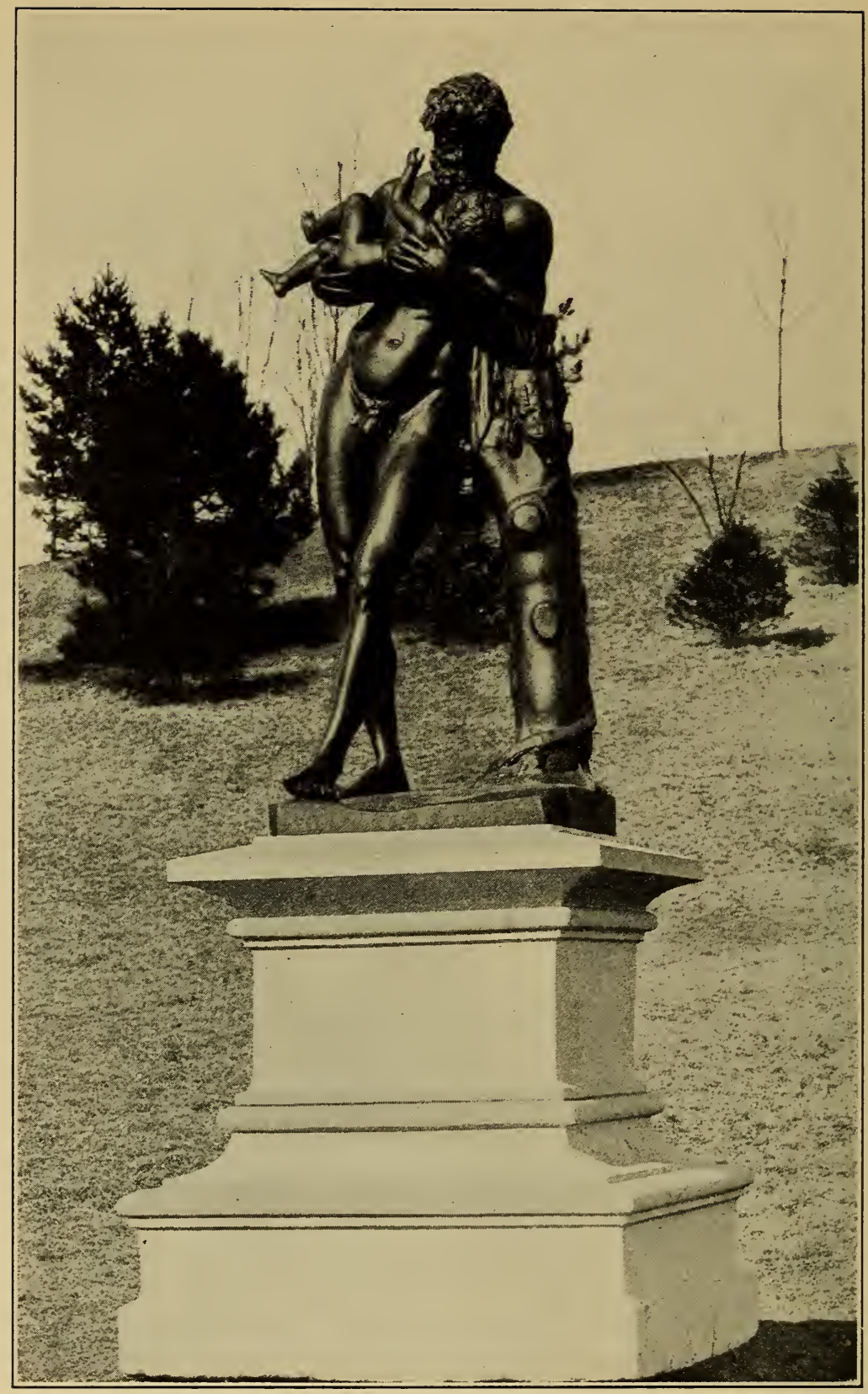

"SILENUS AND THE INFANT BACCHUS"........................ Bronze

Supposed to be the work of Praxiteles. Reproduced in bronze by Barbedienne, Paris, France, from the original in the Louvre. Purchased by the Association. Erected on a pedestal of granite, on the east side of the Main Drive, half-way between Fairmount Avenue entrance and Brown Street entrance to the old Park, in November, 1885. 


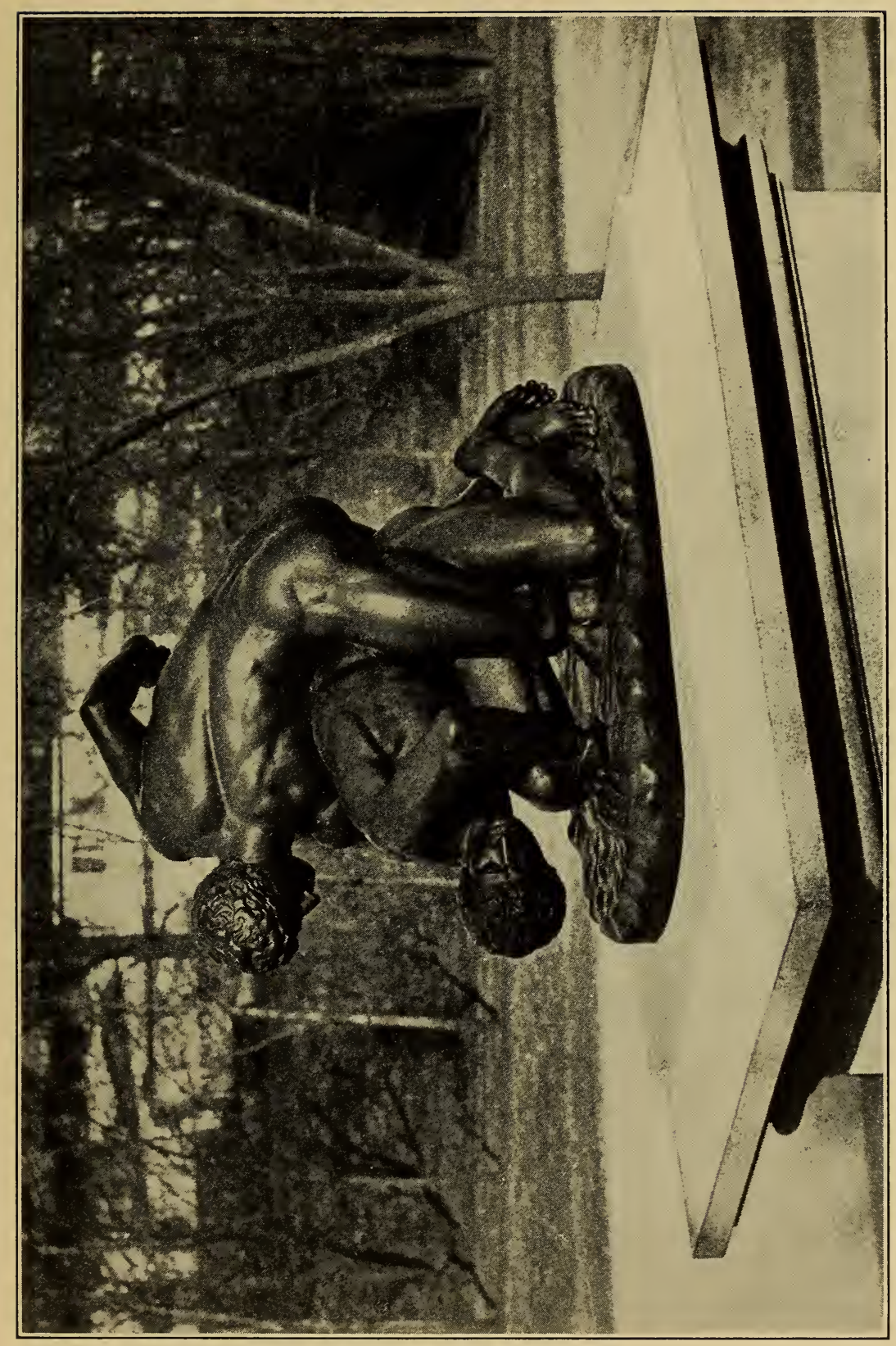

ธิ๊

눙

पू क

它

焉

ธड

\&

른

I5 5

$\Xi \div$

כ㱐

选要

สำ

के 민용

1 원

นิ

되 칠

$F$

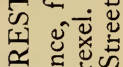

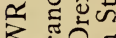

政.

壳 कीष्ठ

恼志

हี

类程

을 등

ติ. हूँ

合象皆

촐

号원

$\Xi$ 可

उ

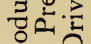

迎突至 


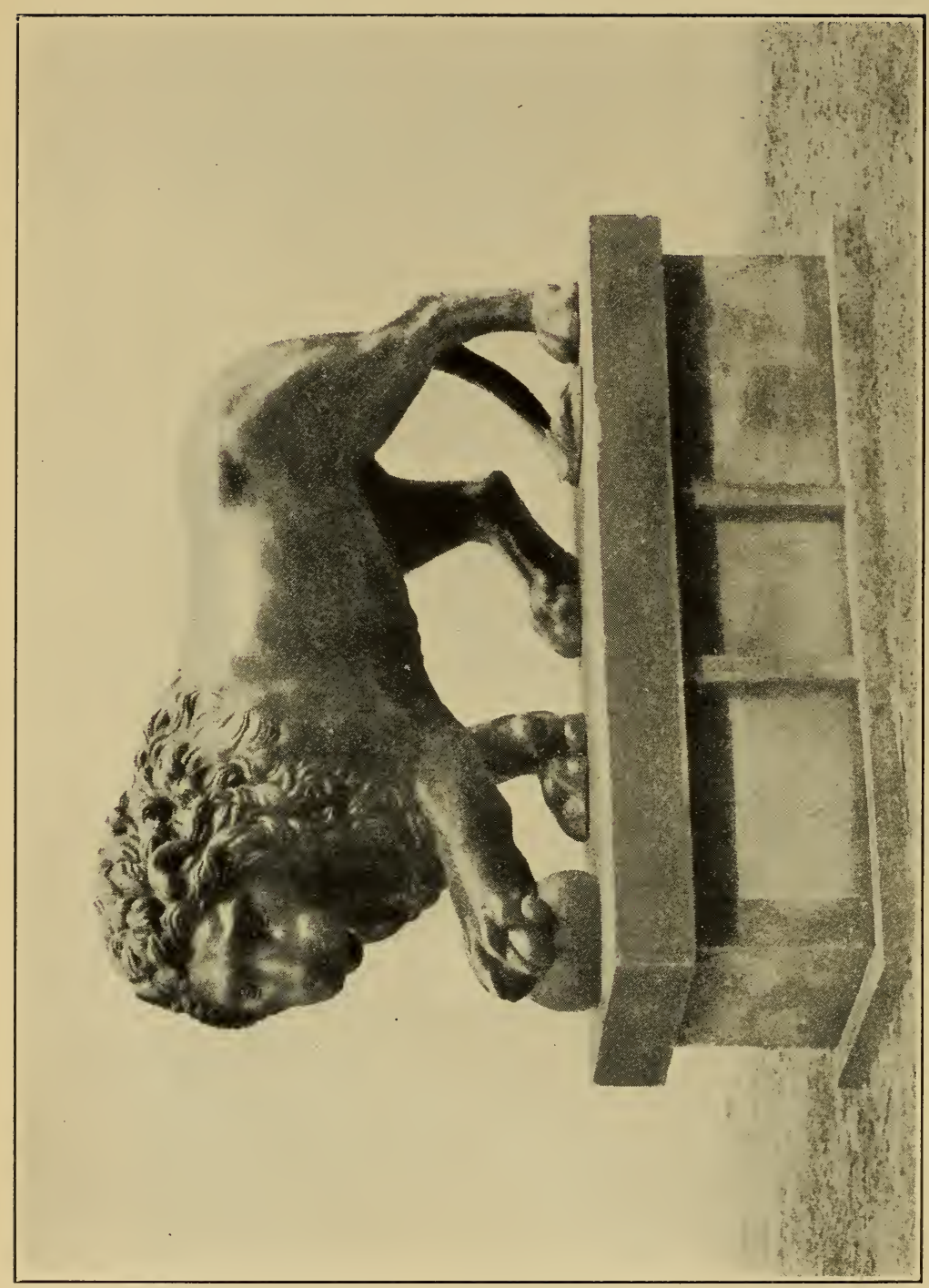

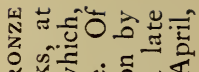

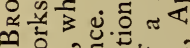

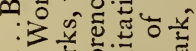

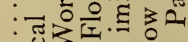

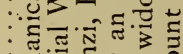

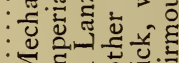

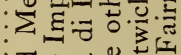
: वृّ :工

:

: हैँ

: हี

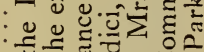

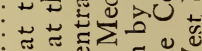
: 듕 :

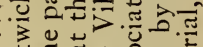
: क्षّ

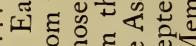
$\varnothing$ \&

: 2 हूँ $\therefore \cong$

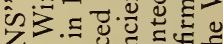
合 등.

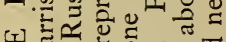

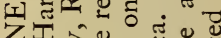

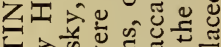

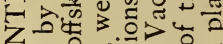

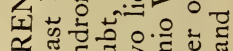

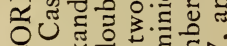

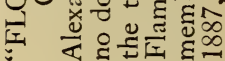




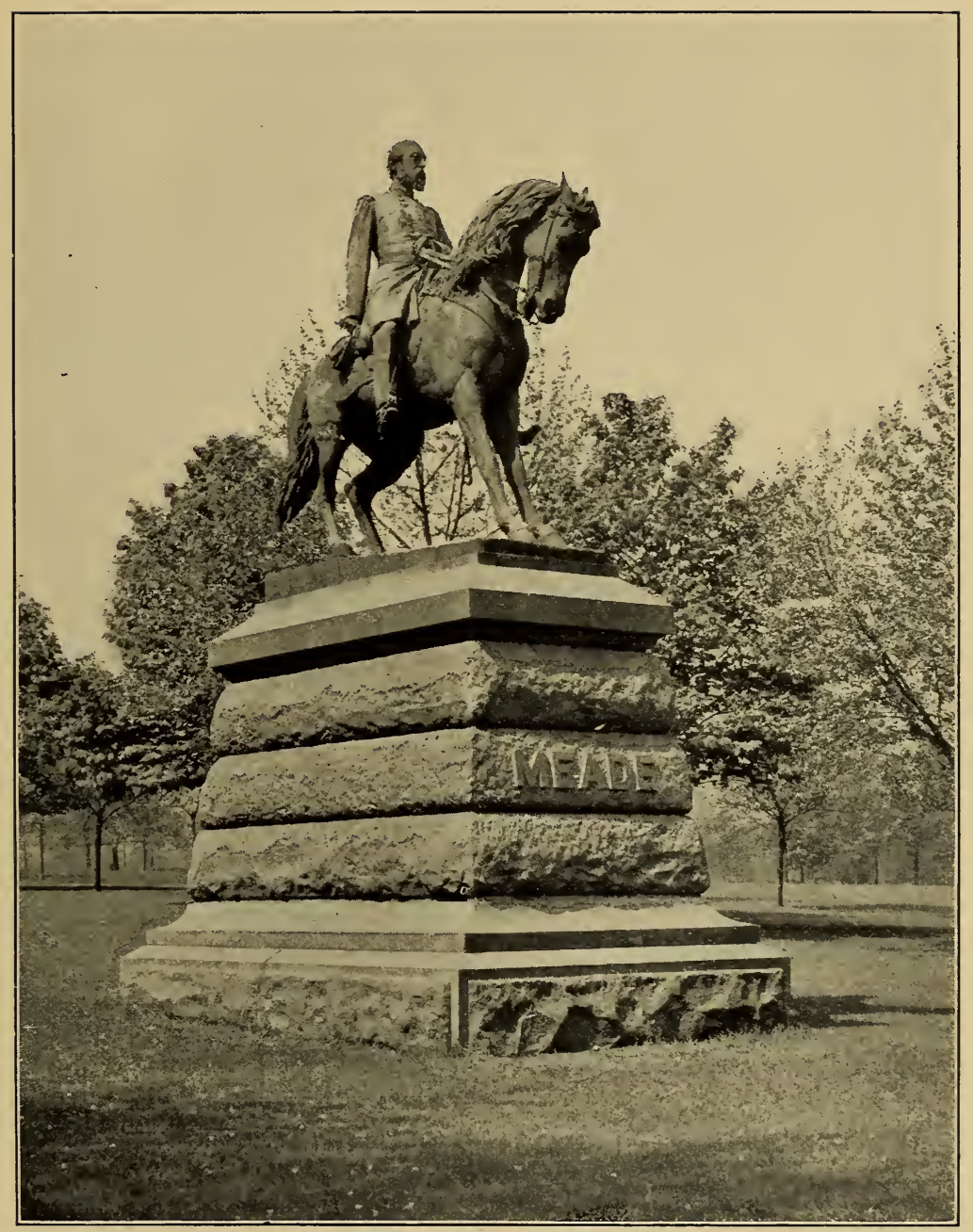

\section{MAJOR GENERAL GEORGE GORDON MEADE-Bronze BY ALEXANDER MILNE CALDER \\ A Commission from the Association}

The United States Government donated a number of captured cannon, and the Legislature of the State of Pennsylvania appropriated the sum of \$5000 toward the expense of the granite pedestal; special subscriptions largely aided by the Women's Auxiliary Committee completed the fund necessary for its erection.

Cast by the Henry-Bonnard Company. Mounted on a pedestal of Pennsylvania granite. Placed north of Memorial Hall. Accepted by the Commissioners of Fairmount Park, October 18,1887 , and unveiled with ceremonies participated in by representatives of the mil tary and naval forces of the United States, the Grand Army of the Republic, the National Guard, and by distinguished citizens. 


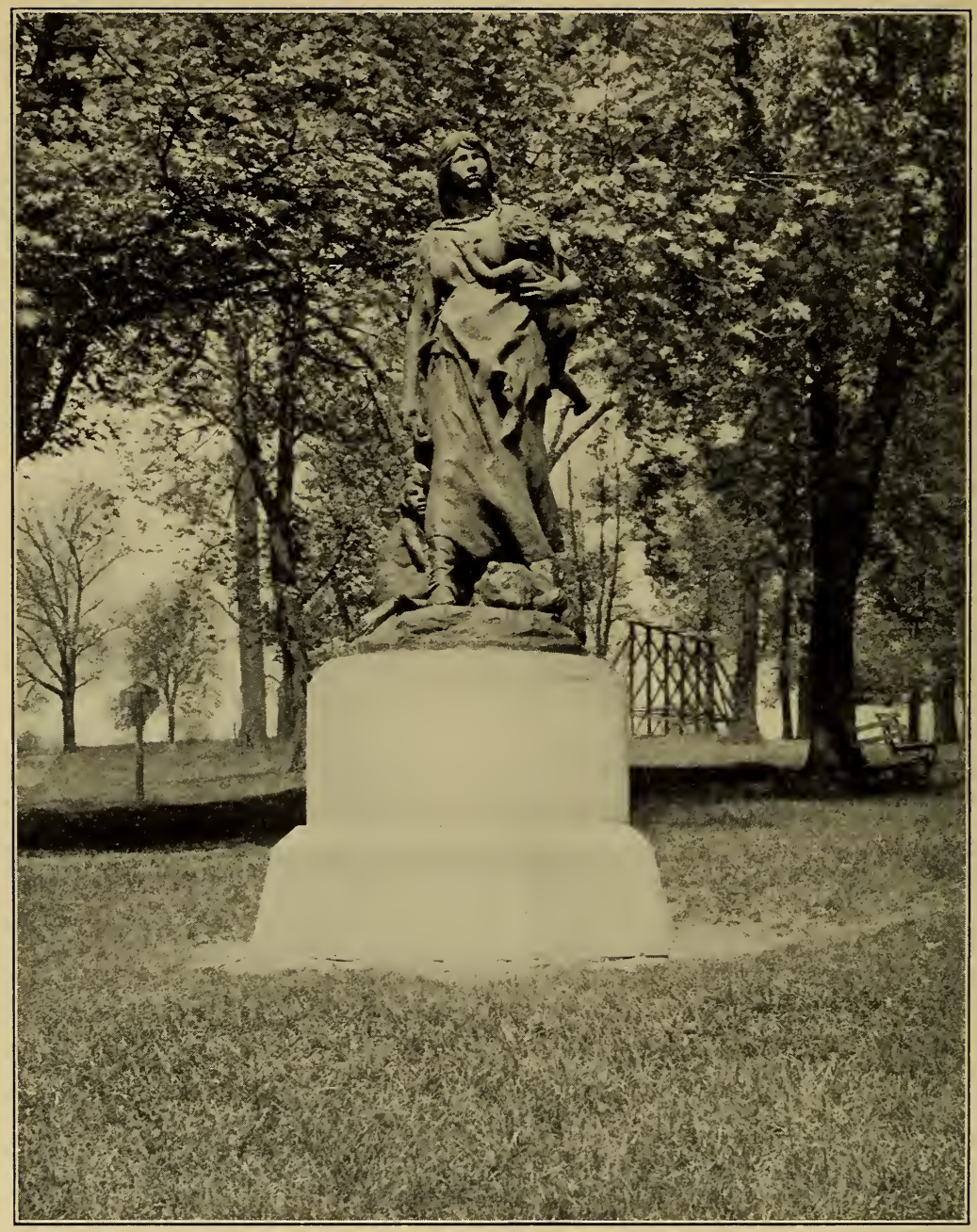

\section{STONE AGE IN AMERICA \\ Indian Group, Bronze}

BY JOHN J. BOYLE

\section{A Commission from the Association}

Mr. Boyle's spirited group represents an Indian mother defending her children from an attack of wild beasts. A bear's cub, which she has killed with her stone hatchet, lies at her feet, and with her baby clasped to her breast she awaits the attack of the savage mother. The group is among the most masterly works which have been added to the works in the Park, and Mr. Boyle is undoubtedly the first sculptor who has adequately presented the Indian's case in American art. It was cast by Barbedienne, of Paris, and placed in West Park, near the Children's Play Ground, in 1888. 


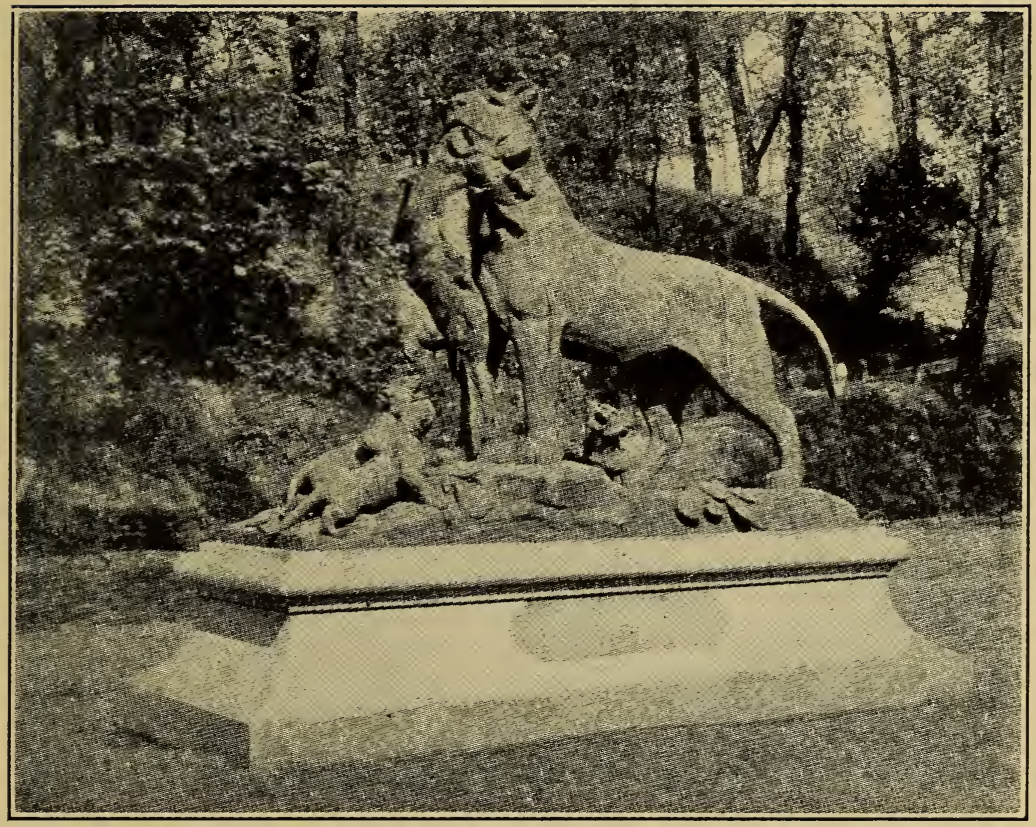

LIONESS CARRYING TO HER YOUNG A WILD BOAR.............. BronzE BY AUGUSTE CAIN

A Commission from the Association

Placed near the Iron Spring and Lincoln Monument, foot of Lemon Hill, 1888. 


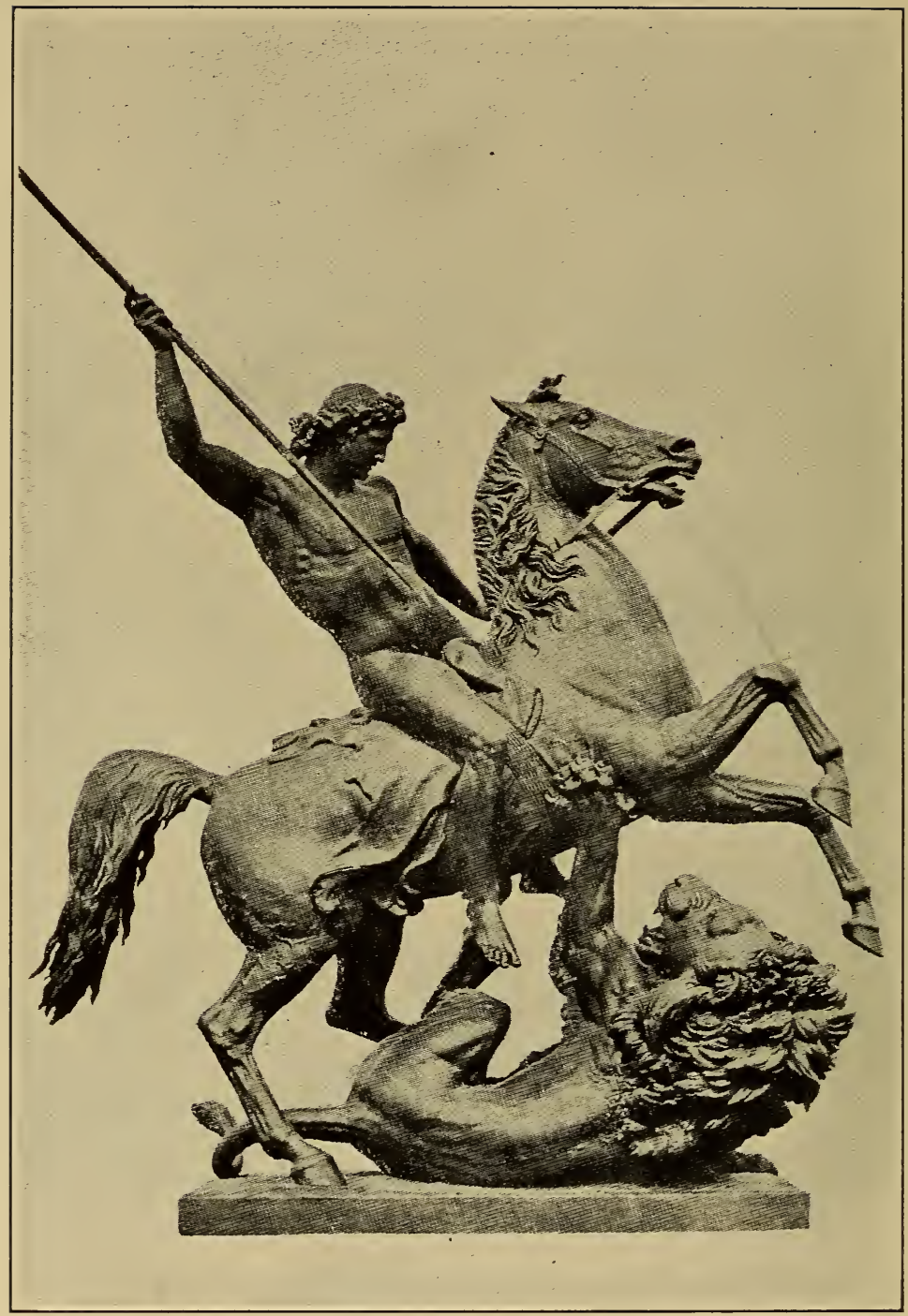

COLOSSAL EQUESTRIAN GROUP, “LION FIGHTER”. .............. BRONZE BY PROF. ALBERT WOLFF, OF BERLIN

Original plaster cast purchased by the Association

Cast in bronze by Bureau Brothers, 1893. Placed on natural jutting rock, East River Drive below Girard Avenue Bridge, June, 1897. 


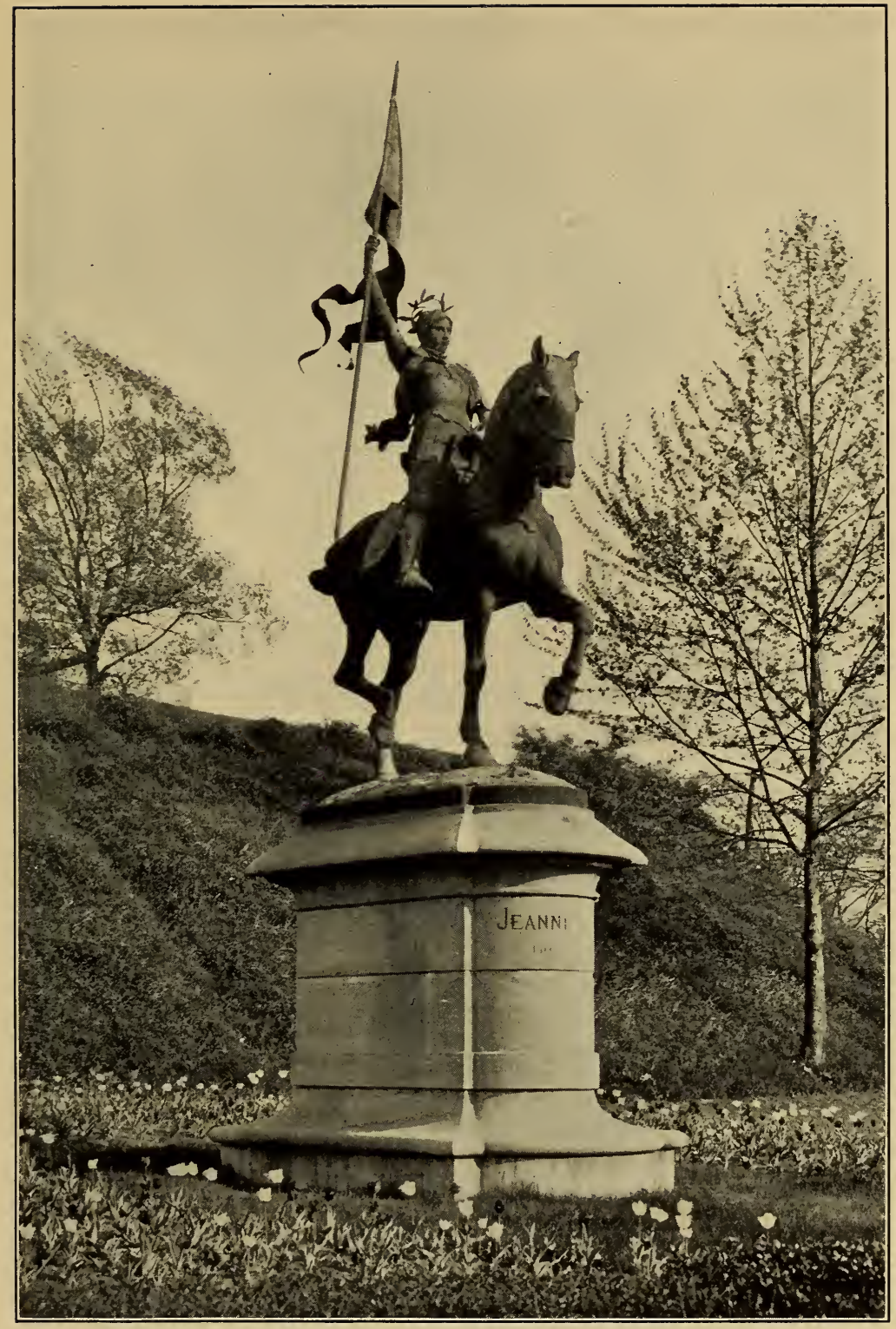

EQUESTRIAN STATUE OF JEANNE D'ARC $\ldots \ldots \ldots \ldots \ldots \ldots \ldots$ BRoNZE BY FREMIET.

The sculptor's more mature conception of the same subject that he trected in 1874, Place des Pyramides, Paris. Purchased by the Association.

Mounted on granite pedestal. Placed near the eastern approach to Girard Avenue Bridge. Accepted by the Commissioners of Fairmount Park, November 15, 1890. 


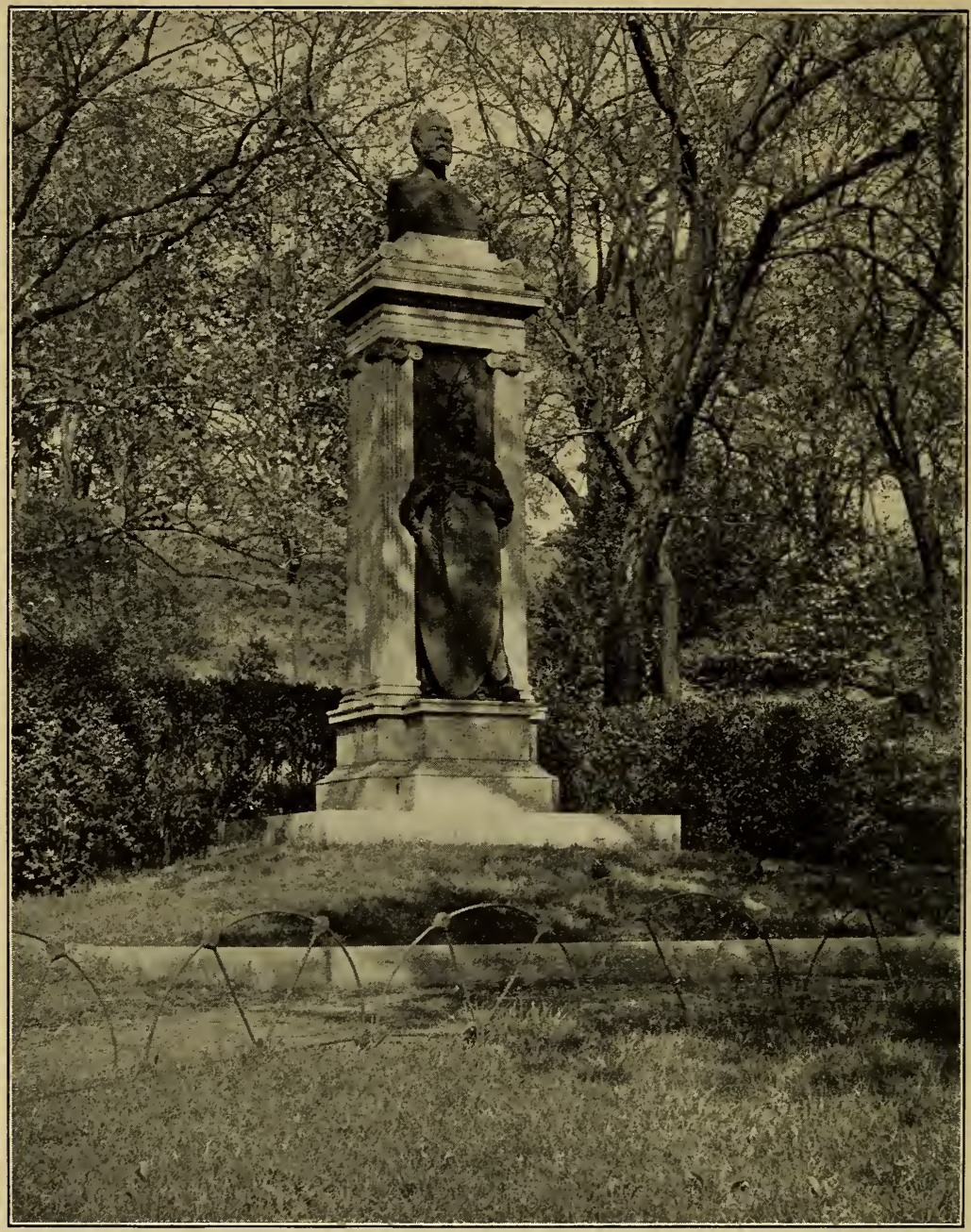

HEROIC BUST OF JAMES A. GARFIELD AND ALLEGORICAL FIGURE-Bronze BY AUGUSTUS ST. GAUDENS

Stanford White, Architect

A Commission from the Association

Erected by special subscription, unveiled with imposing military and naval ceremonies, and accepted by the Commissioners of Fairmount Park, on the evening of Memorial Day, May 30, 1896; followed by a sylvan fete, under the auspices of the Women's Committee on Entertainment. Placed on the East Park Drive below Girard Avenue Bridge and near the Rond point Fountains. 


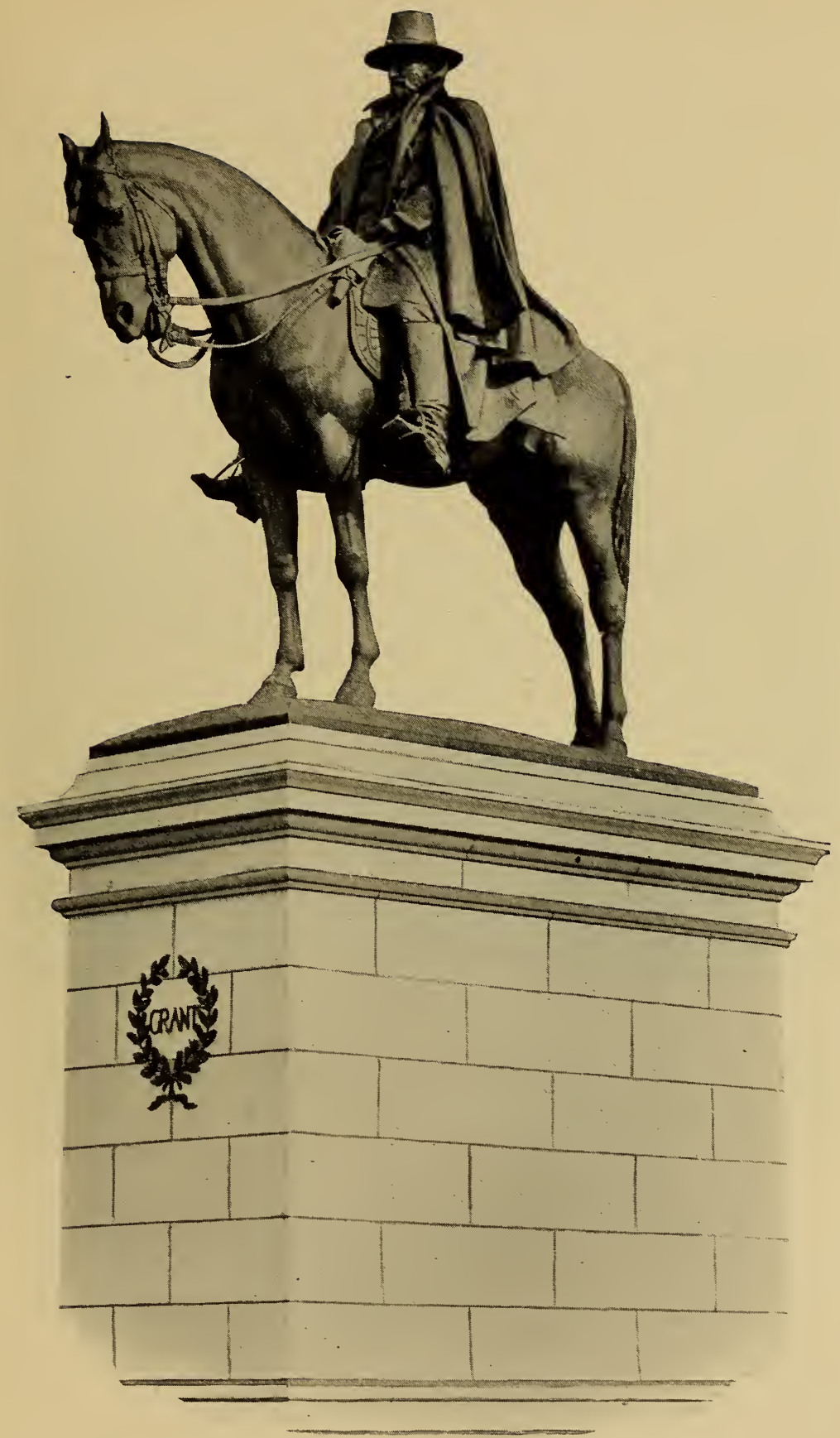

BRONZE EQUESTRIAN STATUE OF GENERAI. U. S. GRANT By Daniel Chester French and Edward C. Potter

Pedestal by Frank Miles Day \& Bro. 


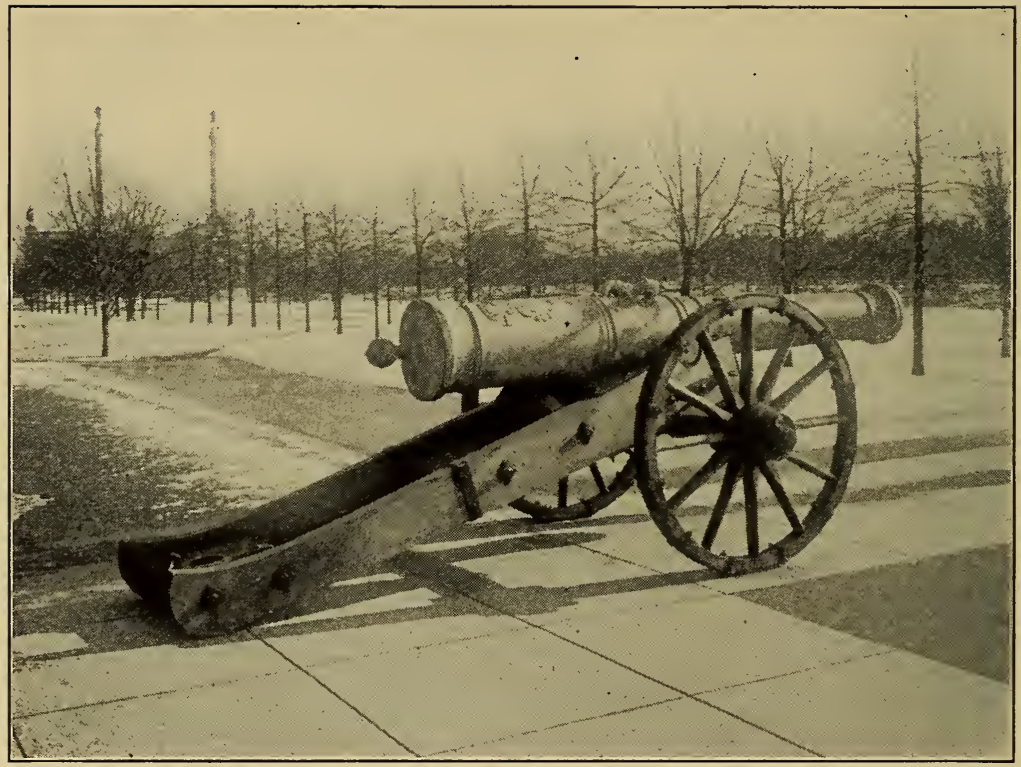

Bronze Spanish Cannon "Miltiades." Date 1743

The above piece, from fortifications in Cuba, is ornamented with carved decorations, including the royal arms of Spain as employed by Philip V and his Queen, Elizabeth Farnese.

Presented to Fairmount Park by the Fairmount Park Art Association in 1899. Remounted on appropriate carriage designed by Charles E. Dana and placed on the terrace in front of Memorial Hall, April, 1912. 


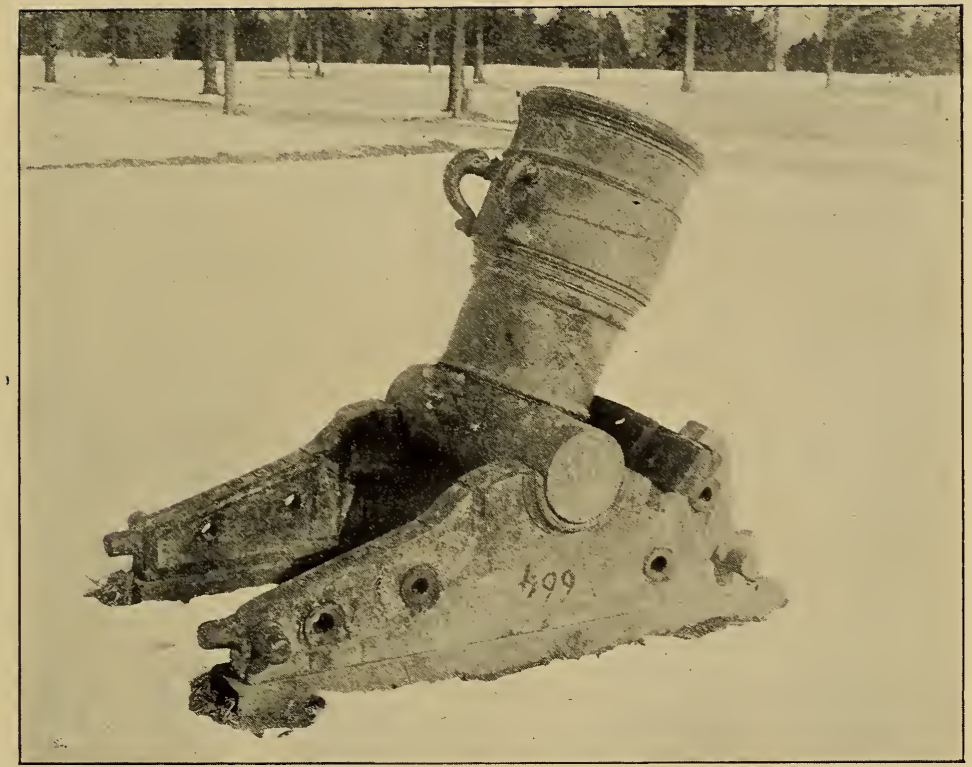

BRONZE SPANISH MORTAR FROM FORTIFICATIONS IN CUBA. DATE 1731. Ornamented with carved decorations, including the royal arms of Spain as employed by Philip V and his Queen Elizabeth Farnese.

Piesented to Fairmount Park by the Fairmount Park Art Association in 1899, and remounted on appropriate carriage designed by Charles E. Dana and placed on the terrace in front of Memorial Hall, April, 1912. 


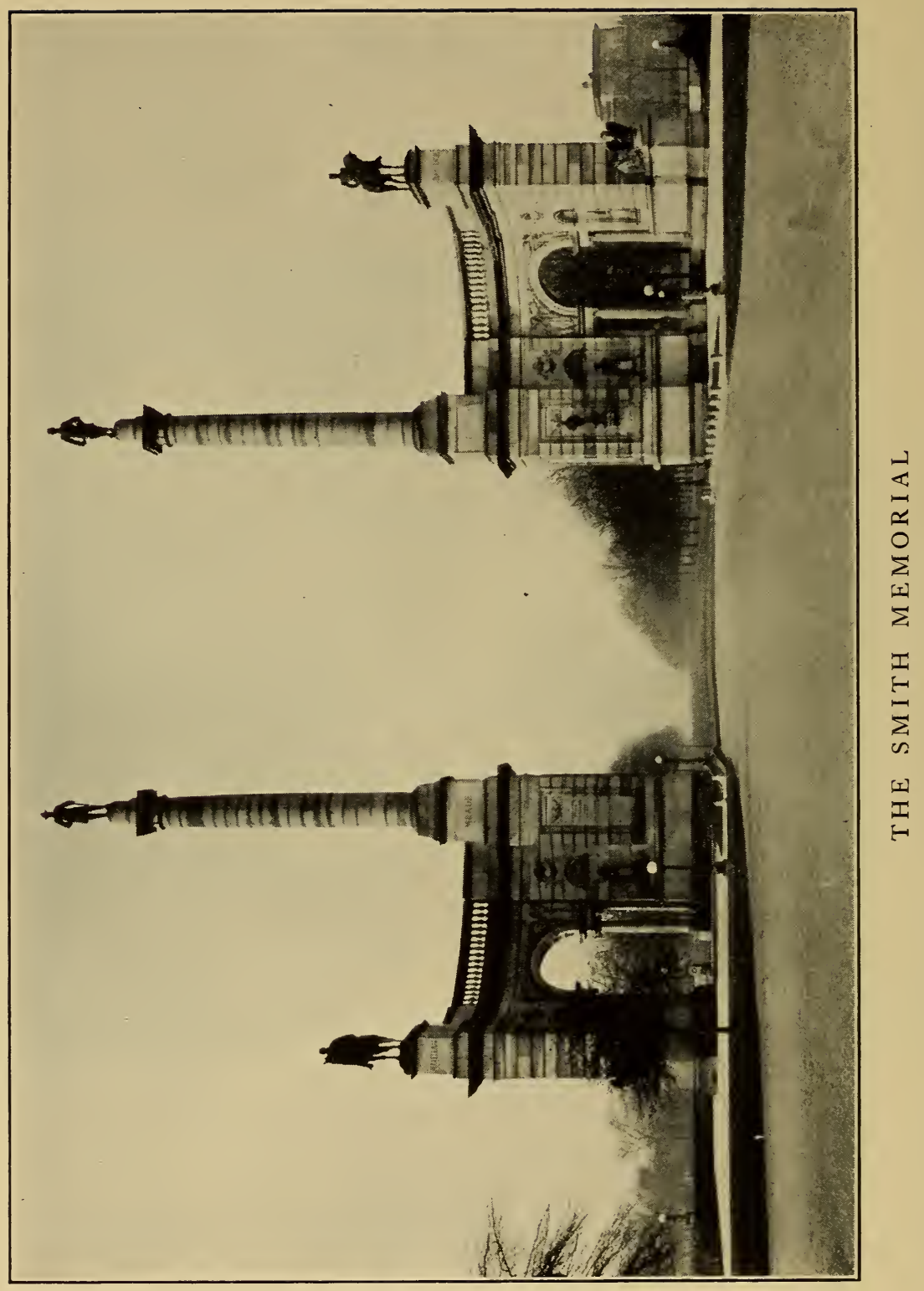




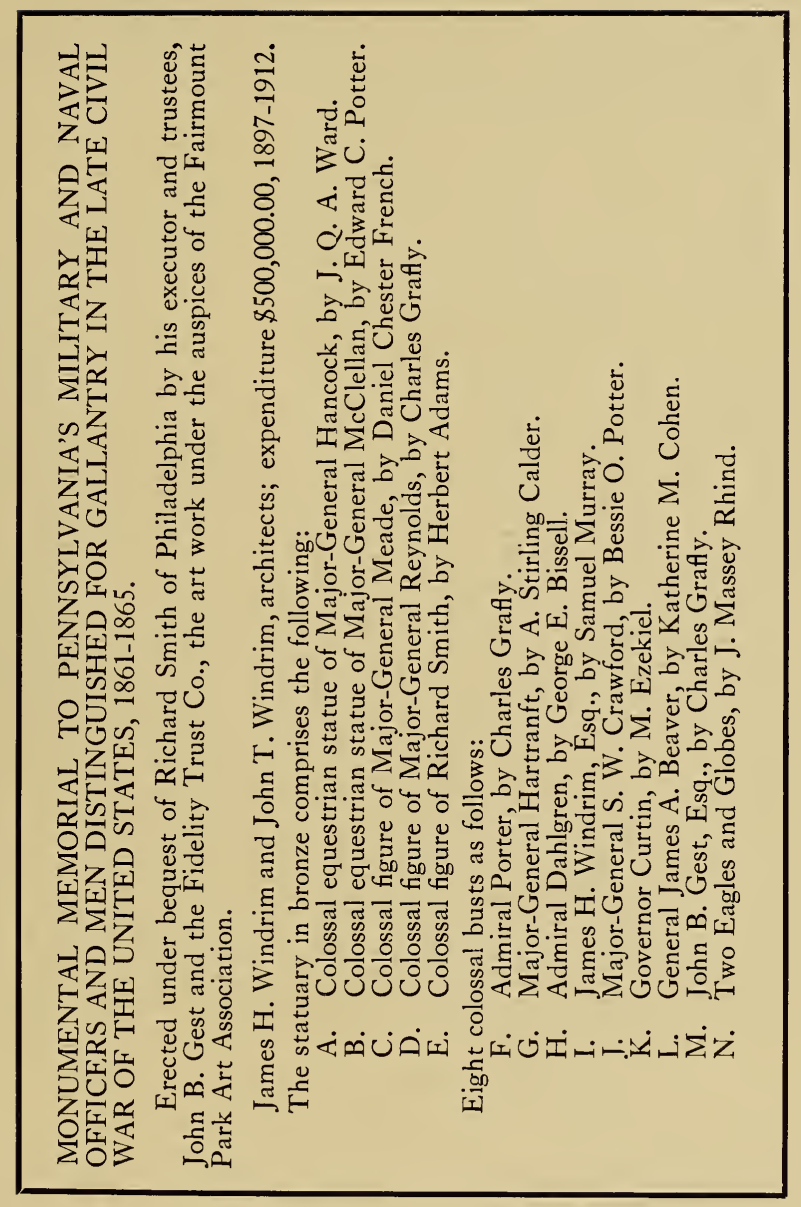




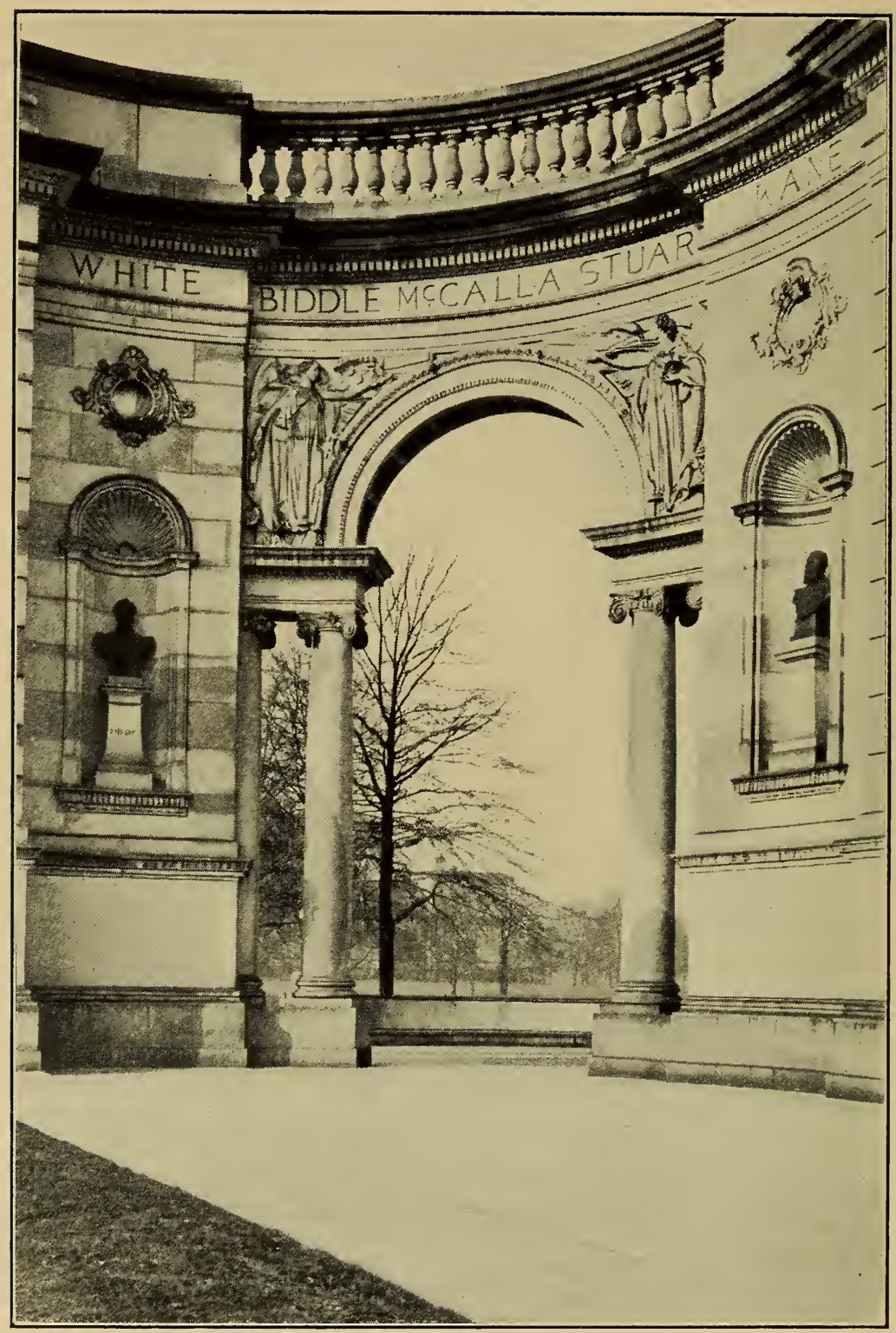

A DETAIL OF THE MONUMENTAL MEMORIAL 


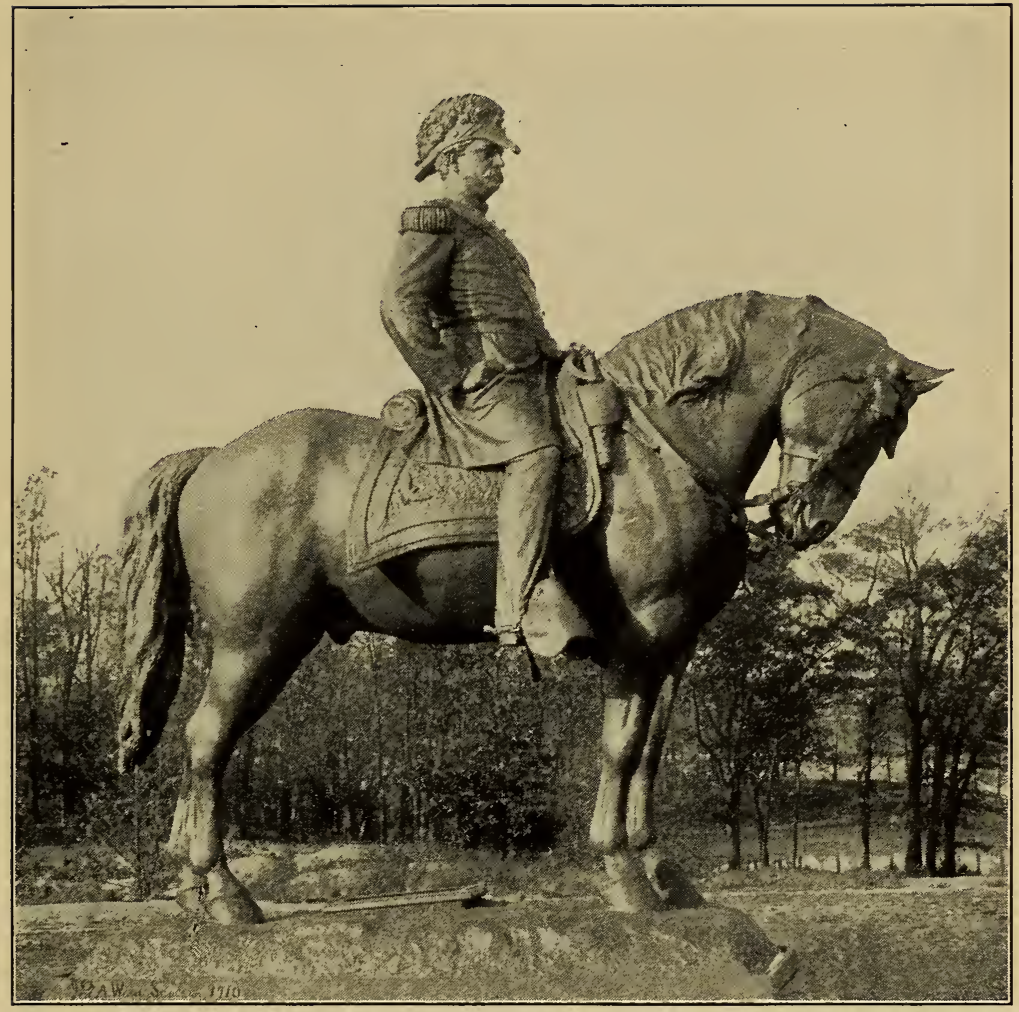

MAJOR-GENERAL WINFIELD SCOTT HANCOCK

Colossal equestrian statue by J. Q. A. Ward. Erected under bequest of Richard Smith on the Monumental Memorial, West Park, 1912

This and the following ten illustrations show individual pieces of sculpture, which are placed on the Monumental Memorial. 


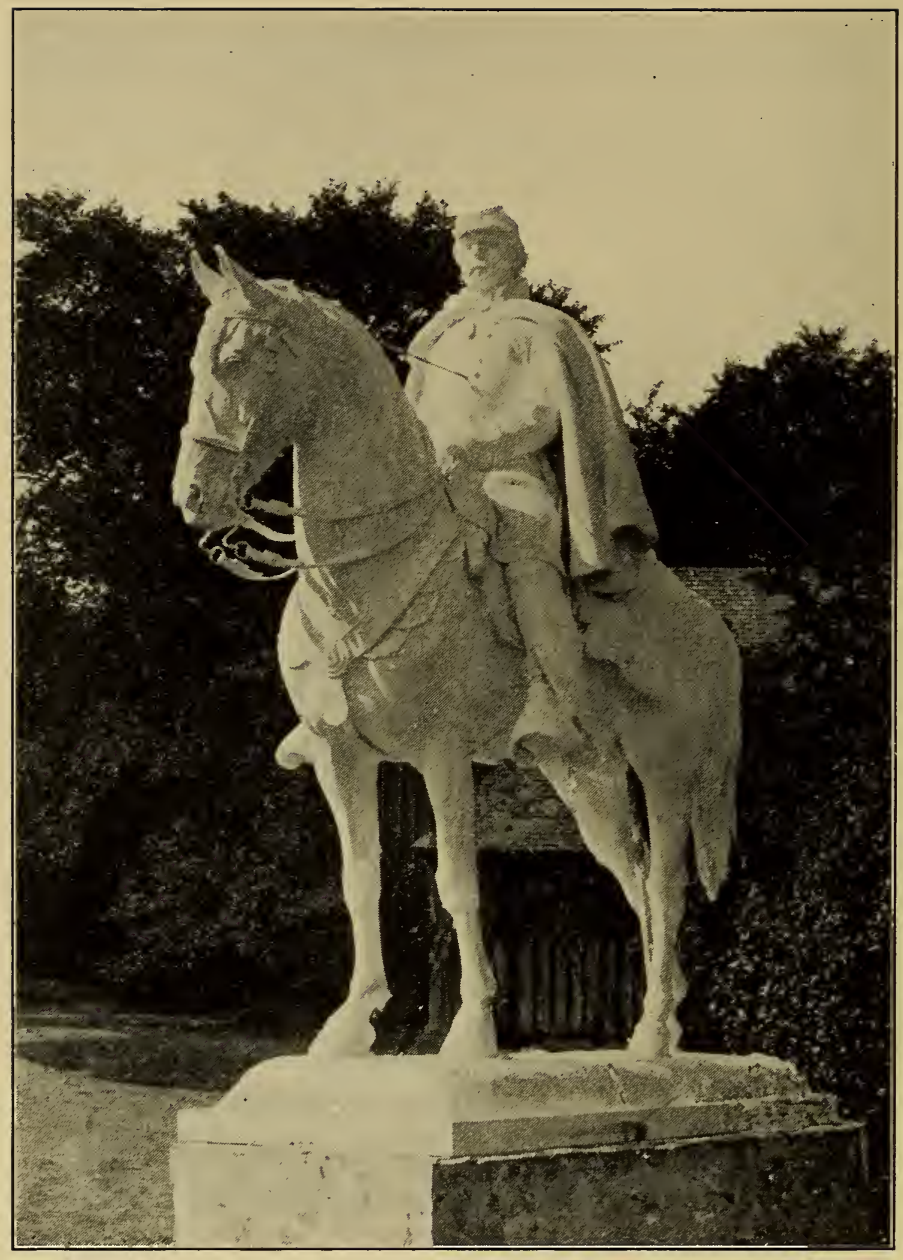

EQUESTRIAN STATUE OF MAJOR-GENERAL McCLELLAN By Edward C. Potter

Erected under bequest of Richard Smith on the Monumental Memorial, West Park, 1912 


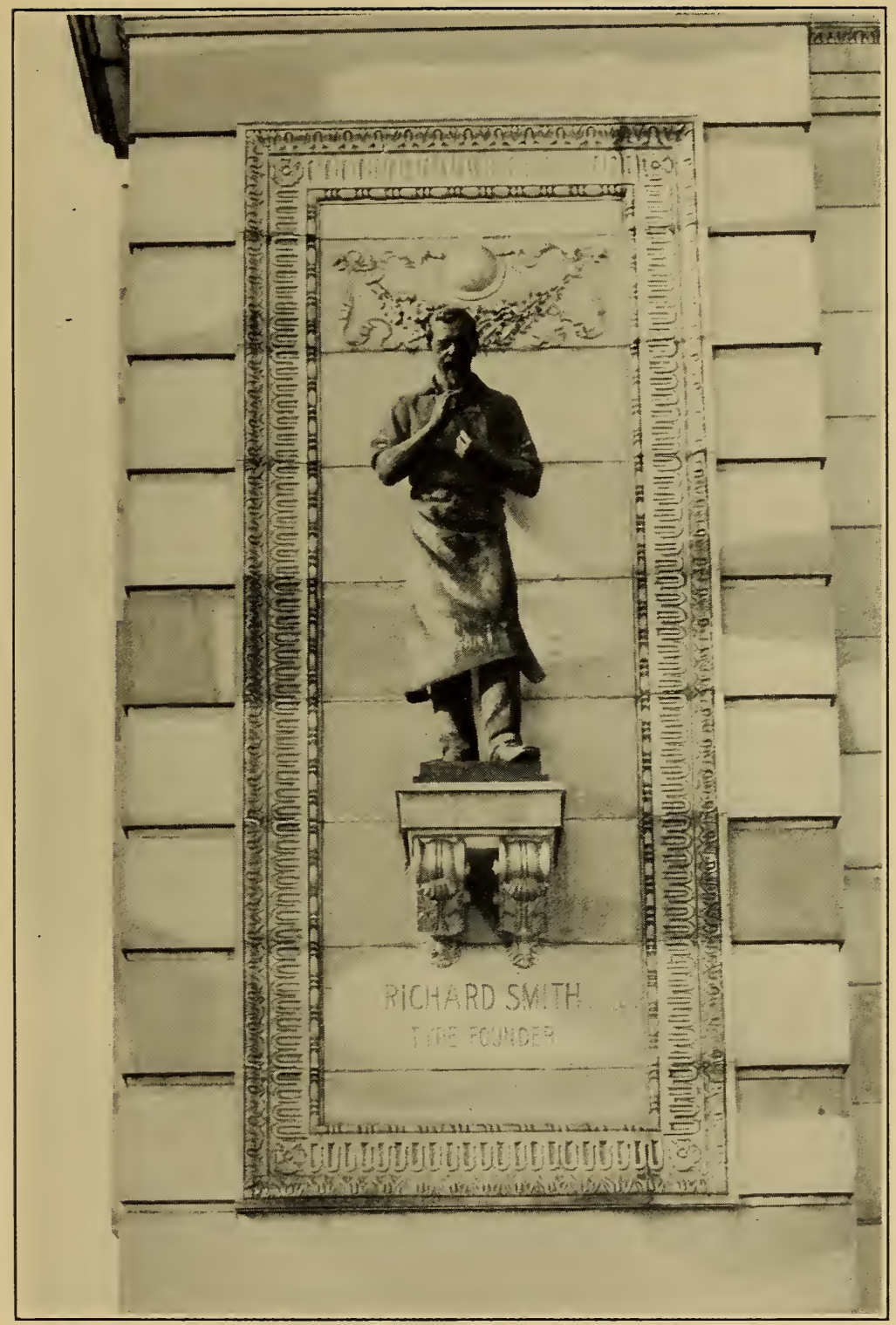

RICHARD SMITH

By Herbert Adams 


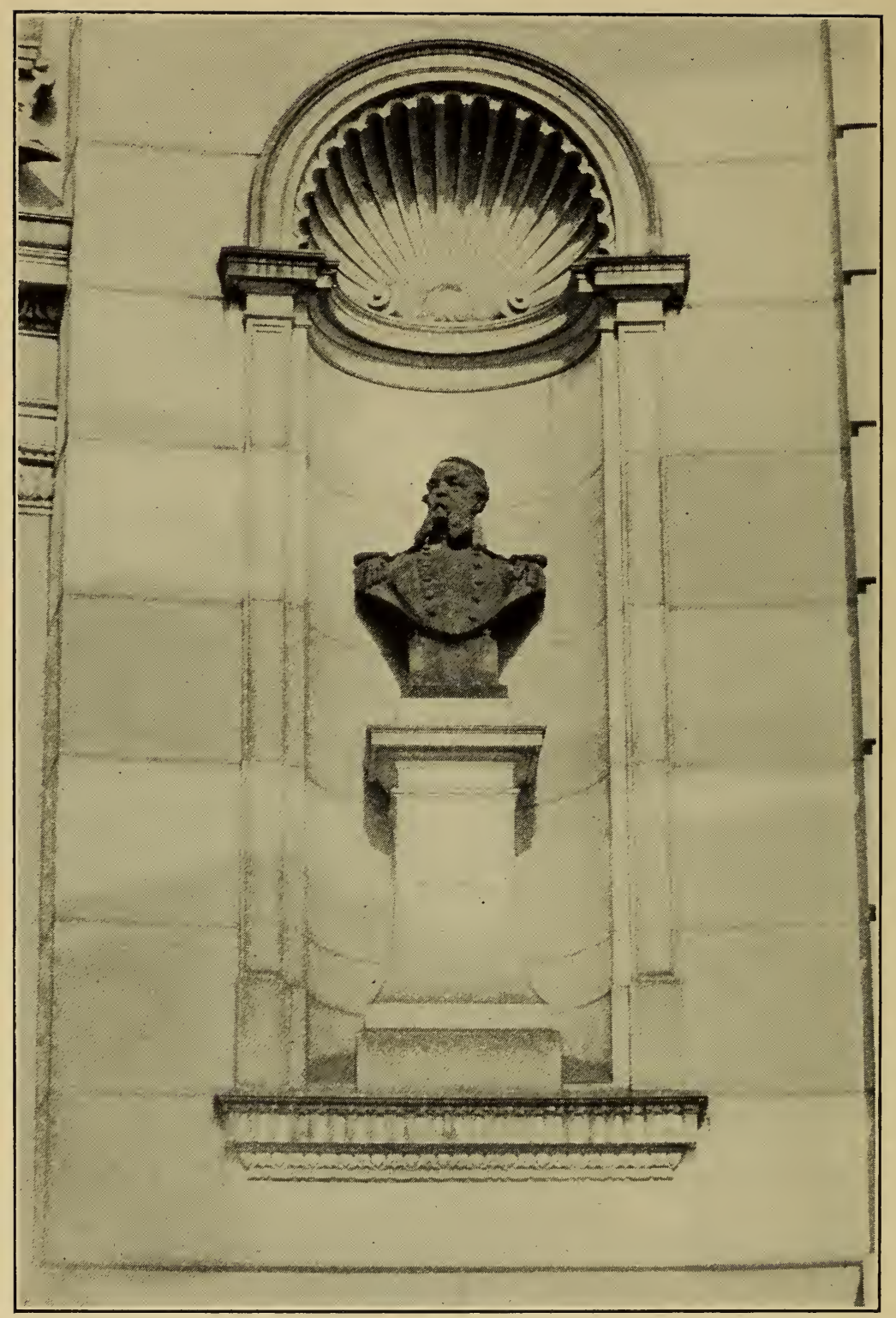

ADMIRAL PORTER

By Charles Grafly 


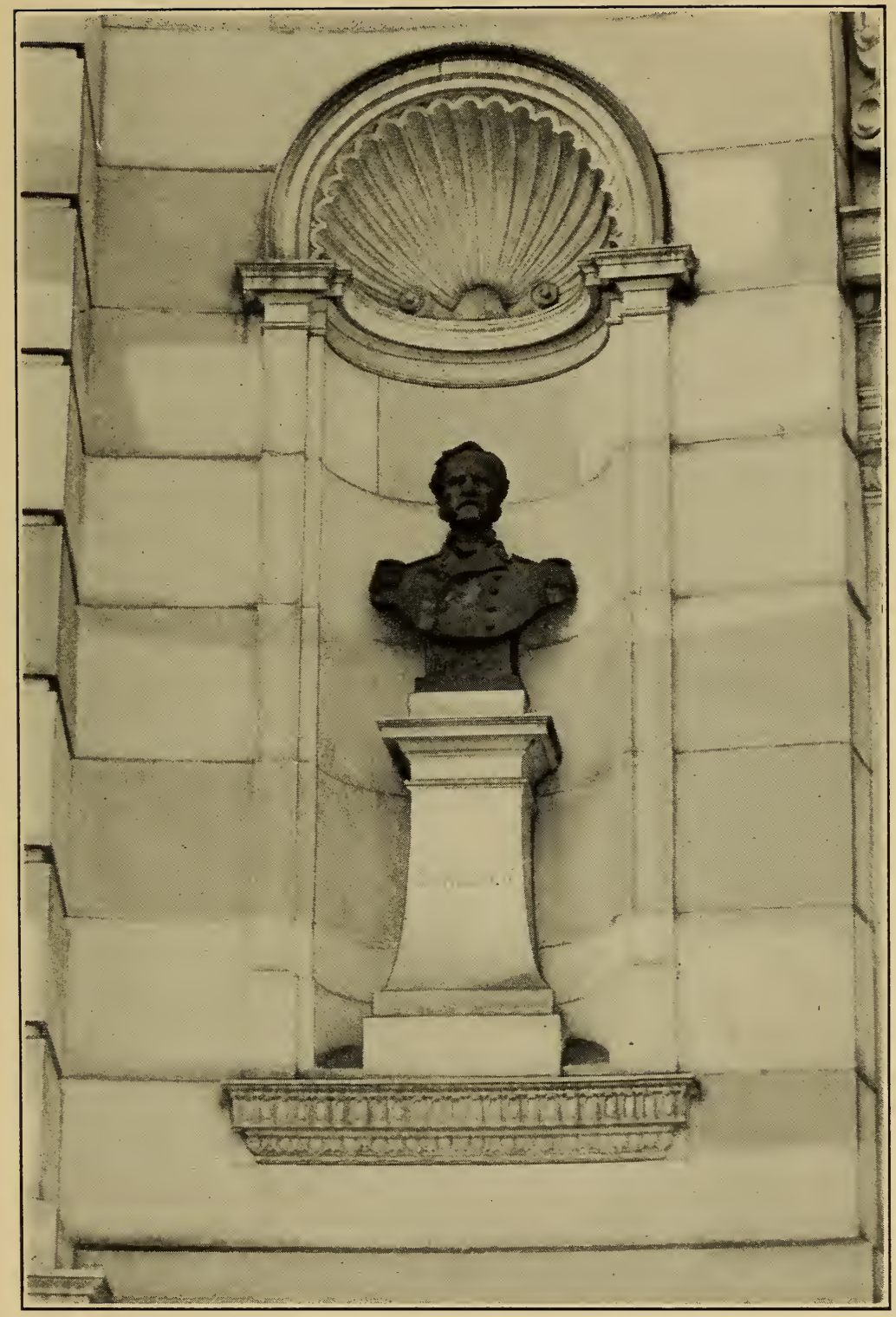

ADMIRAL DAHLGREN

By George E. Bissell 


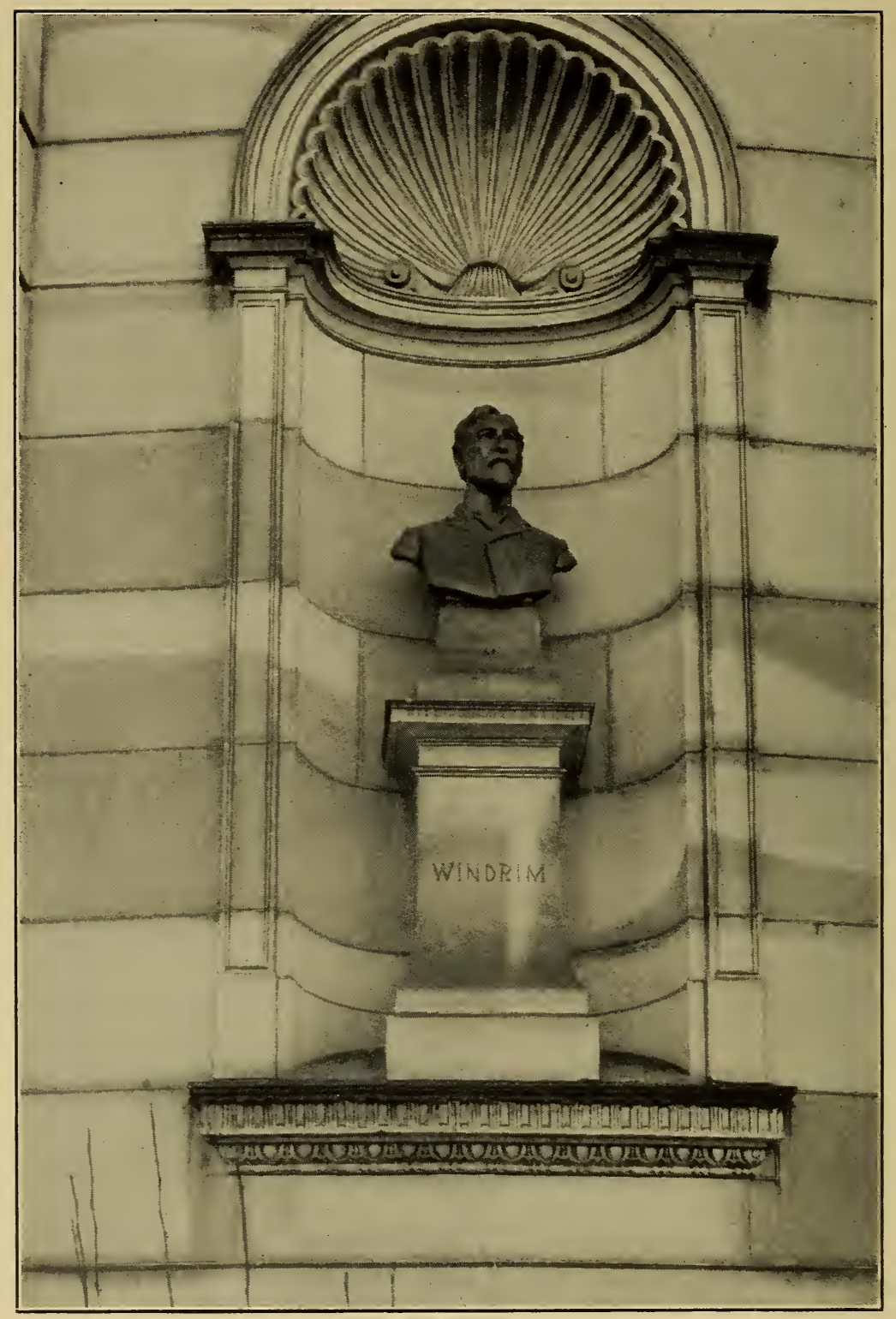

JAMES H. WINDRIM

By Samuel Murray 


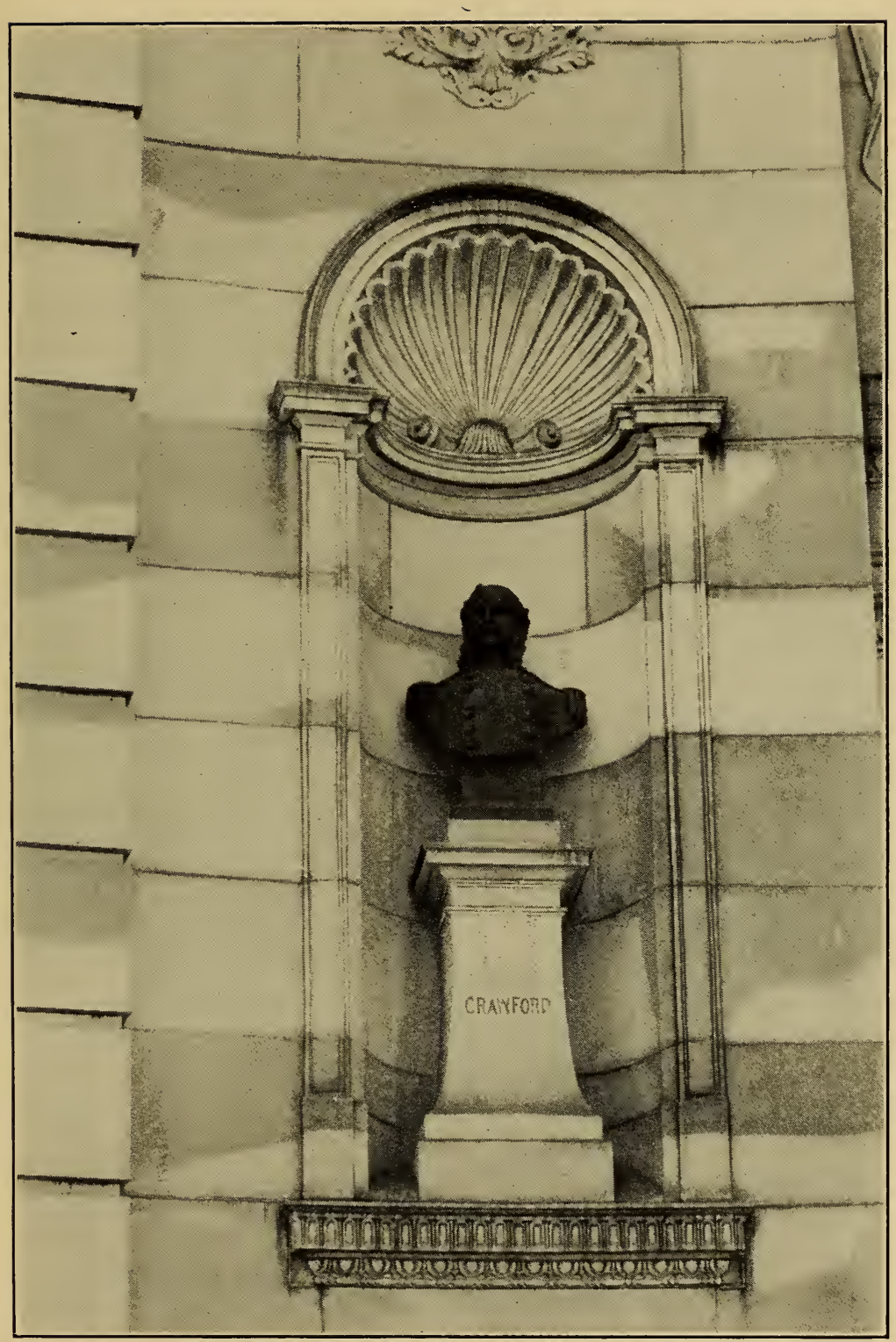

MAJOR-GENERAL S. W. CRAWFORD

By Bessie O. Potter 


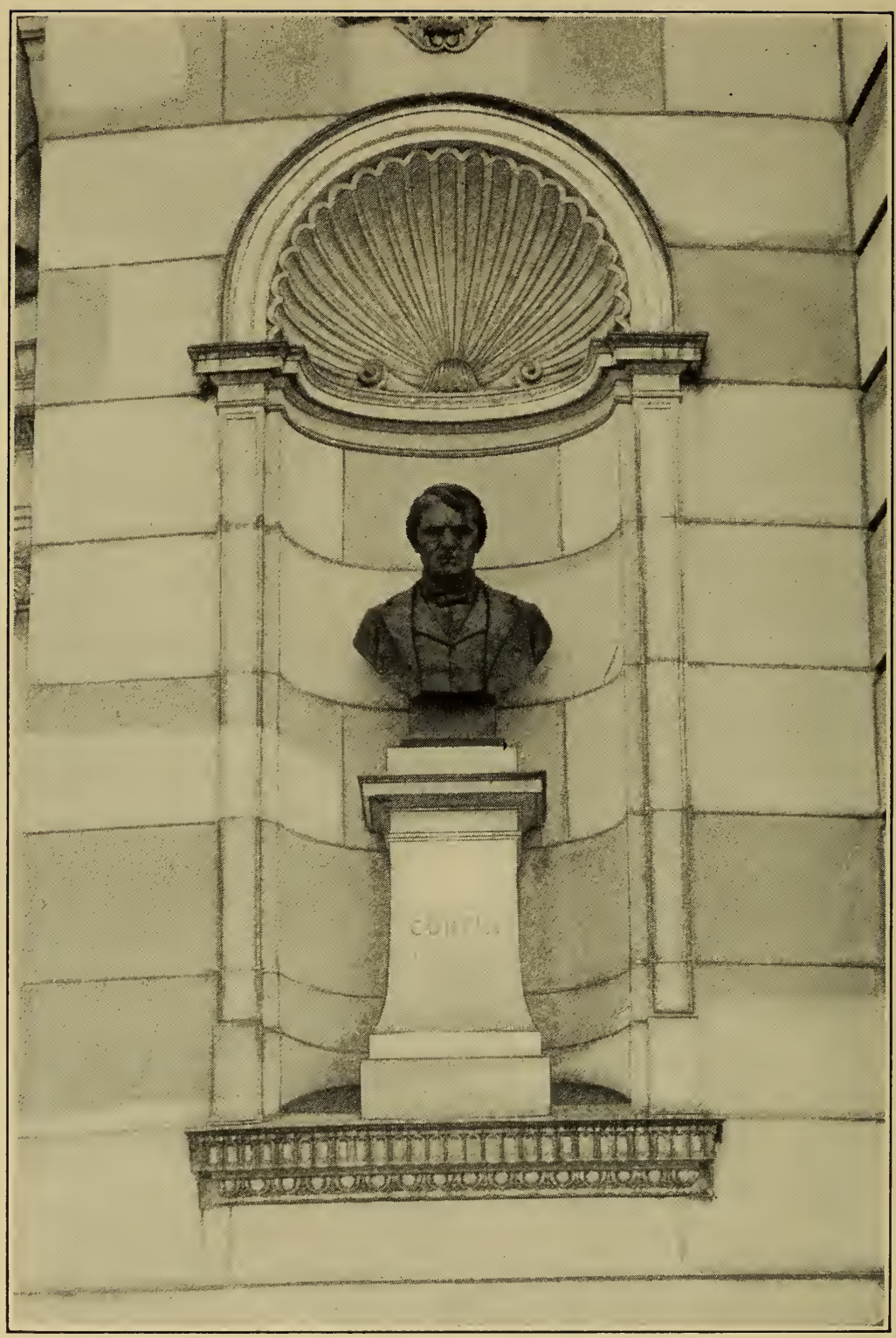

GOVERNOR CURTIN

By M. Ezekiel 


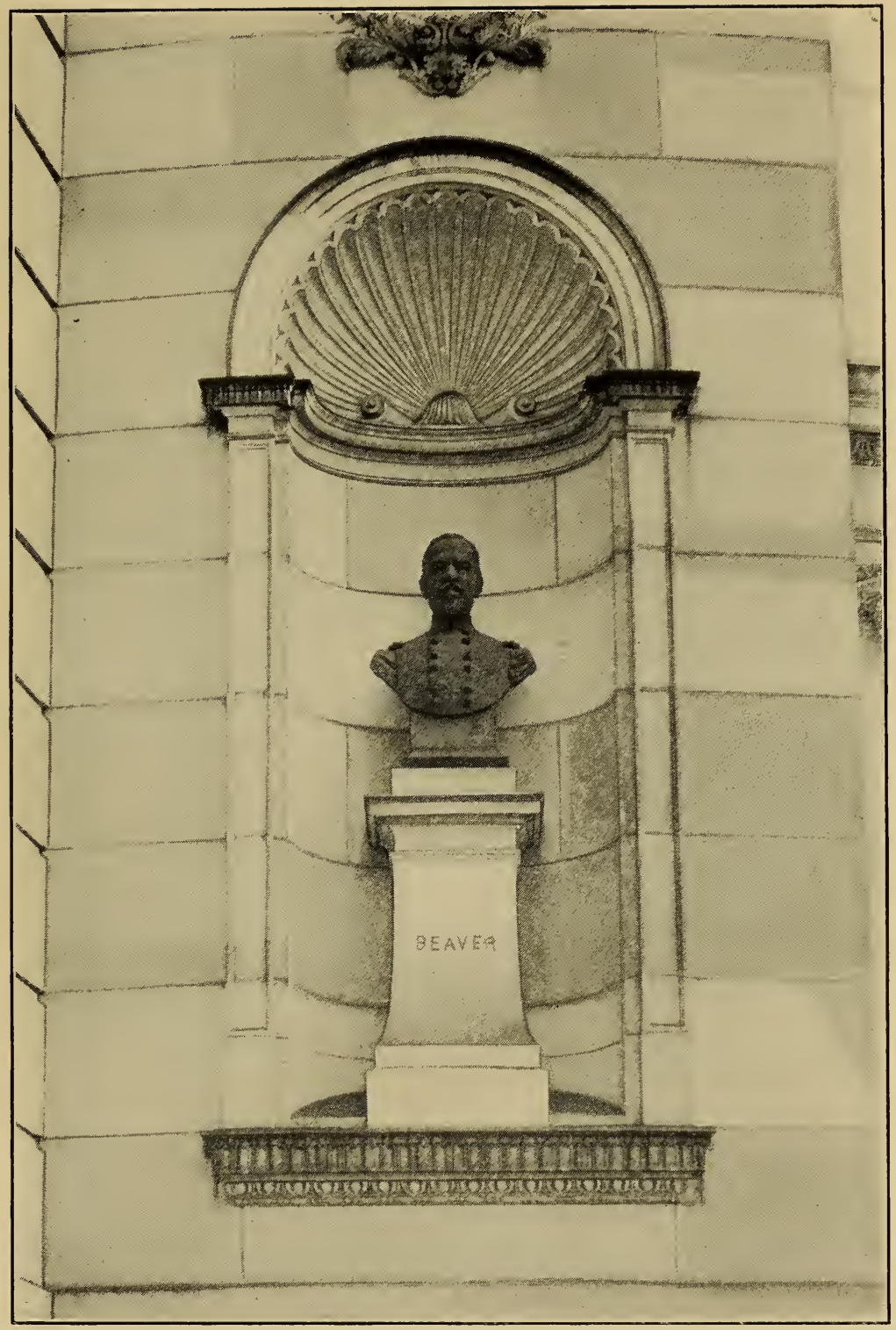

GENERAL JAMES A. BEAVER

By Katherine M. Cohen 


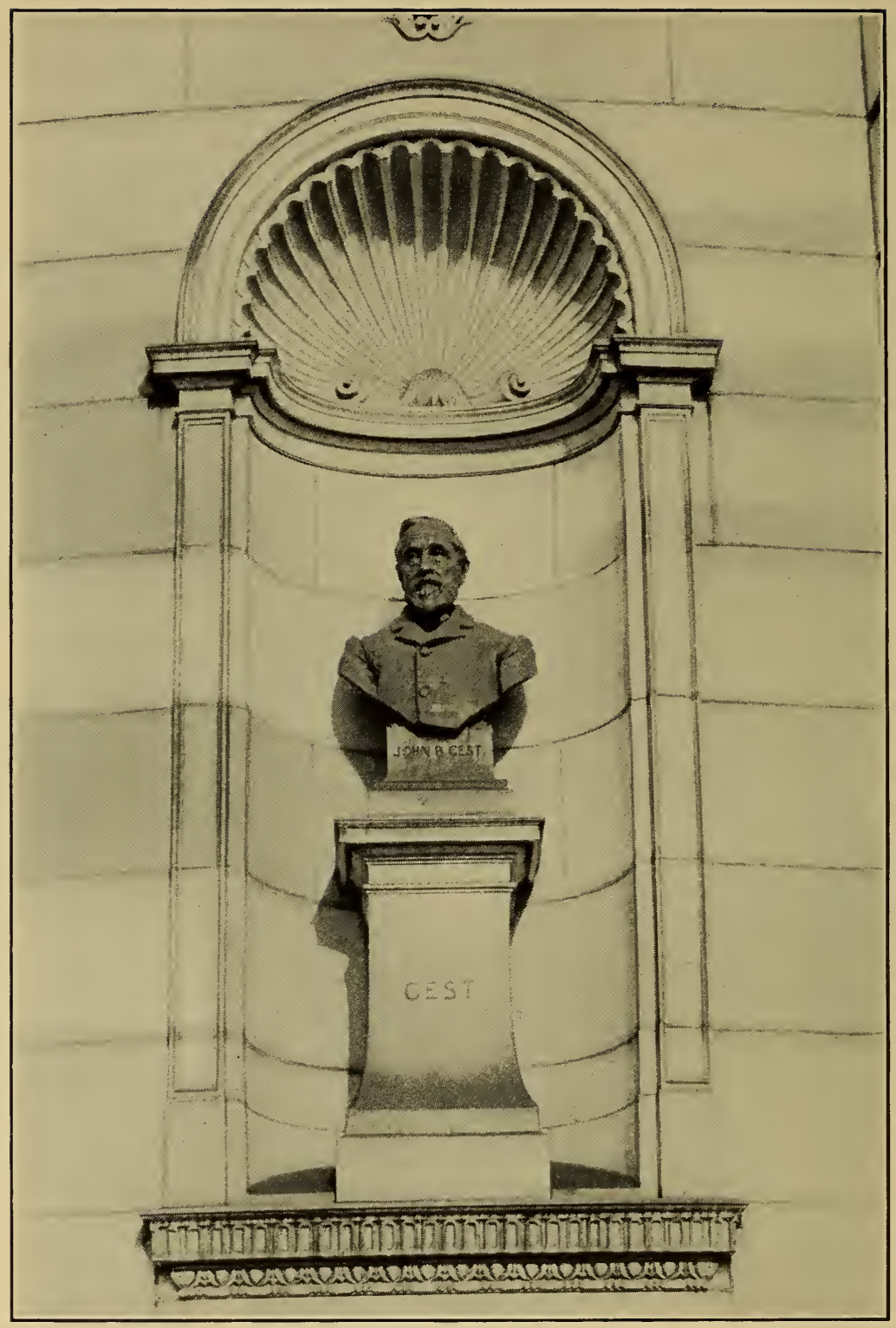

JOHN B. GEST

By Charles Grafly 


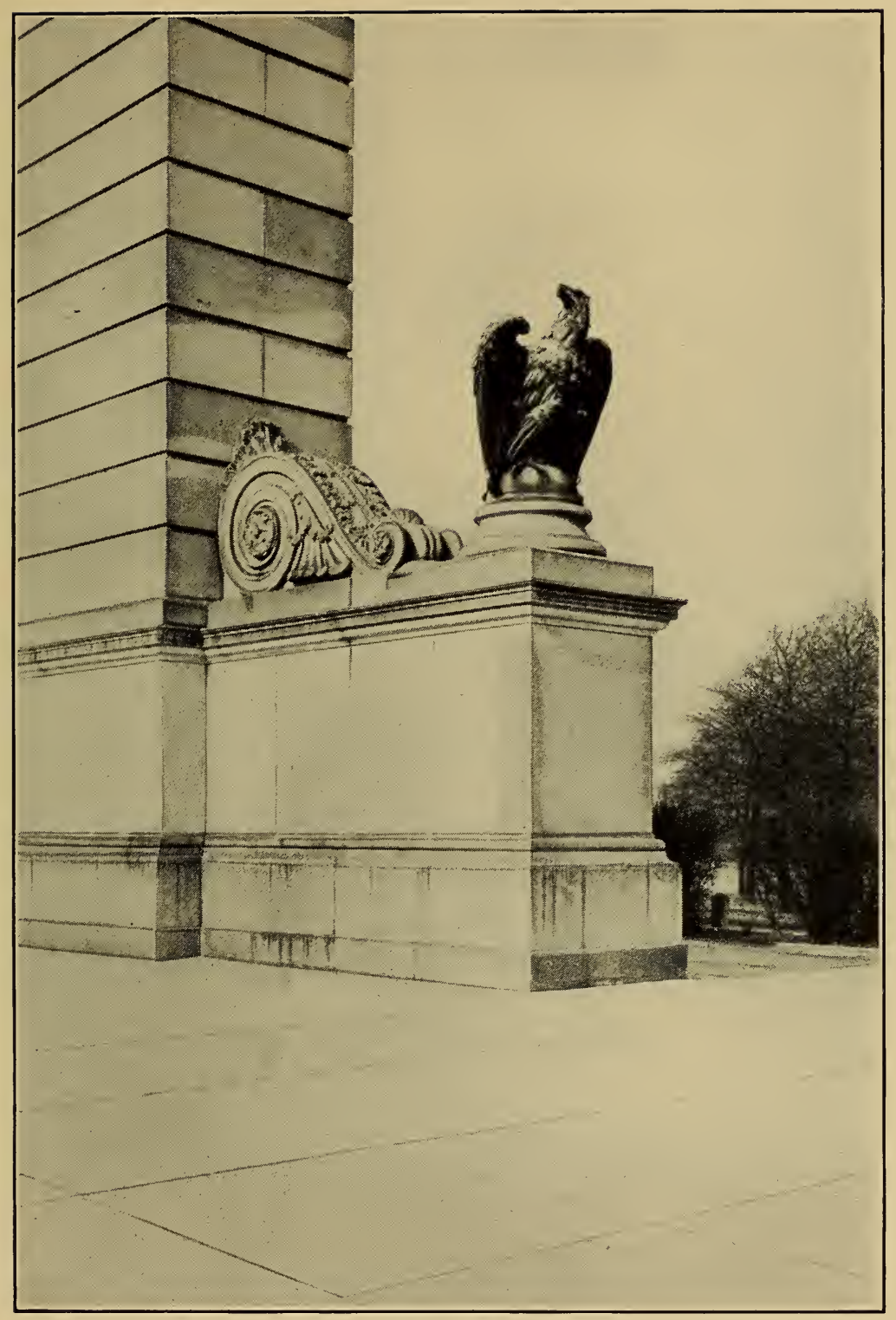

EAGLE

By J. Massey Rhind 


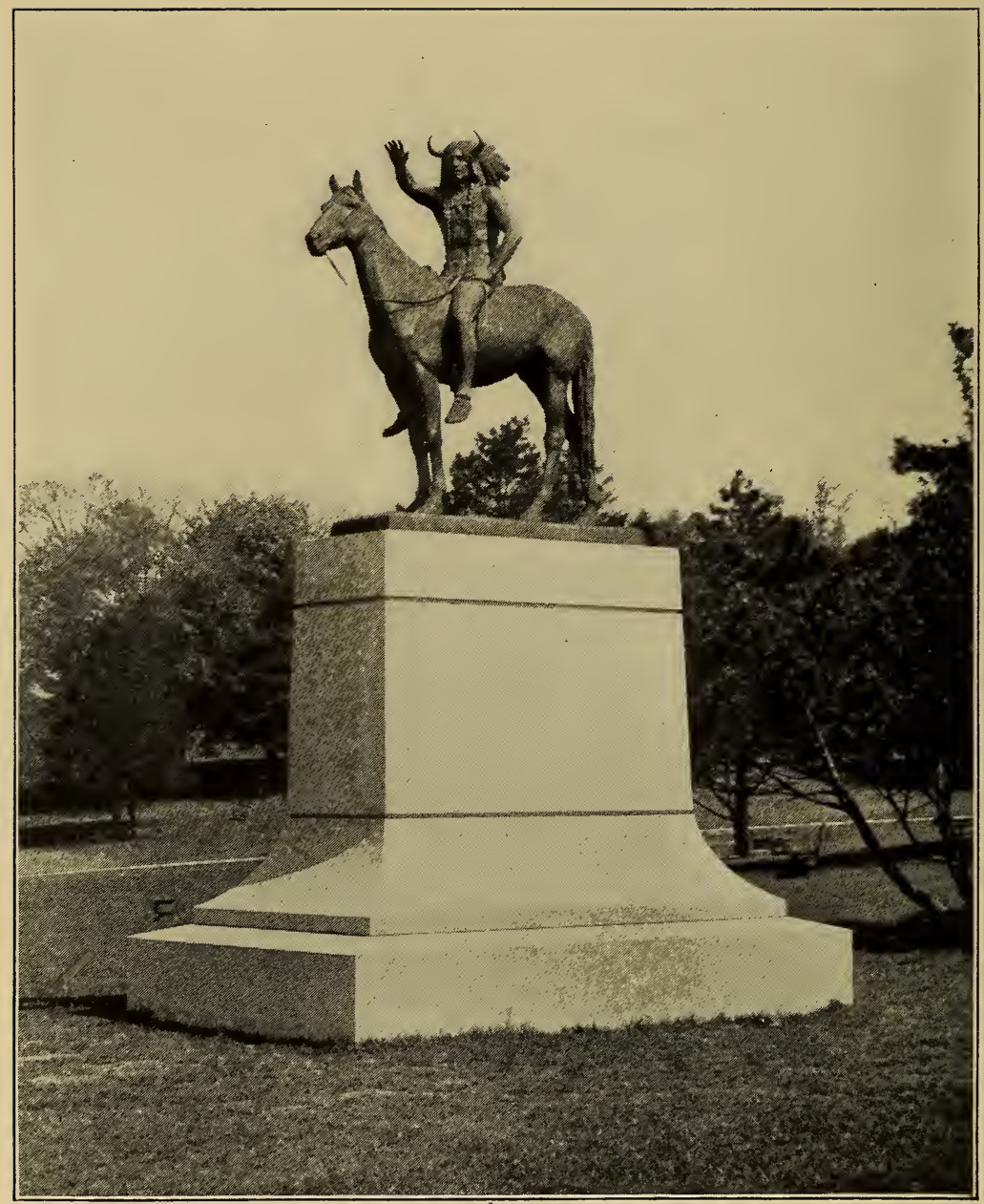

THE MEDICINE MAN

Bronze Equestrian Statue by Cyrus E. Dallin

Erected in East Park at the head of Strawberry Hill, 1903 


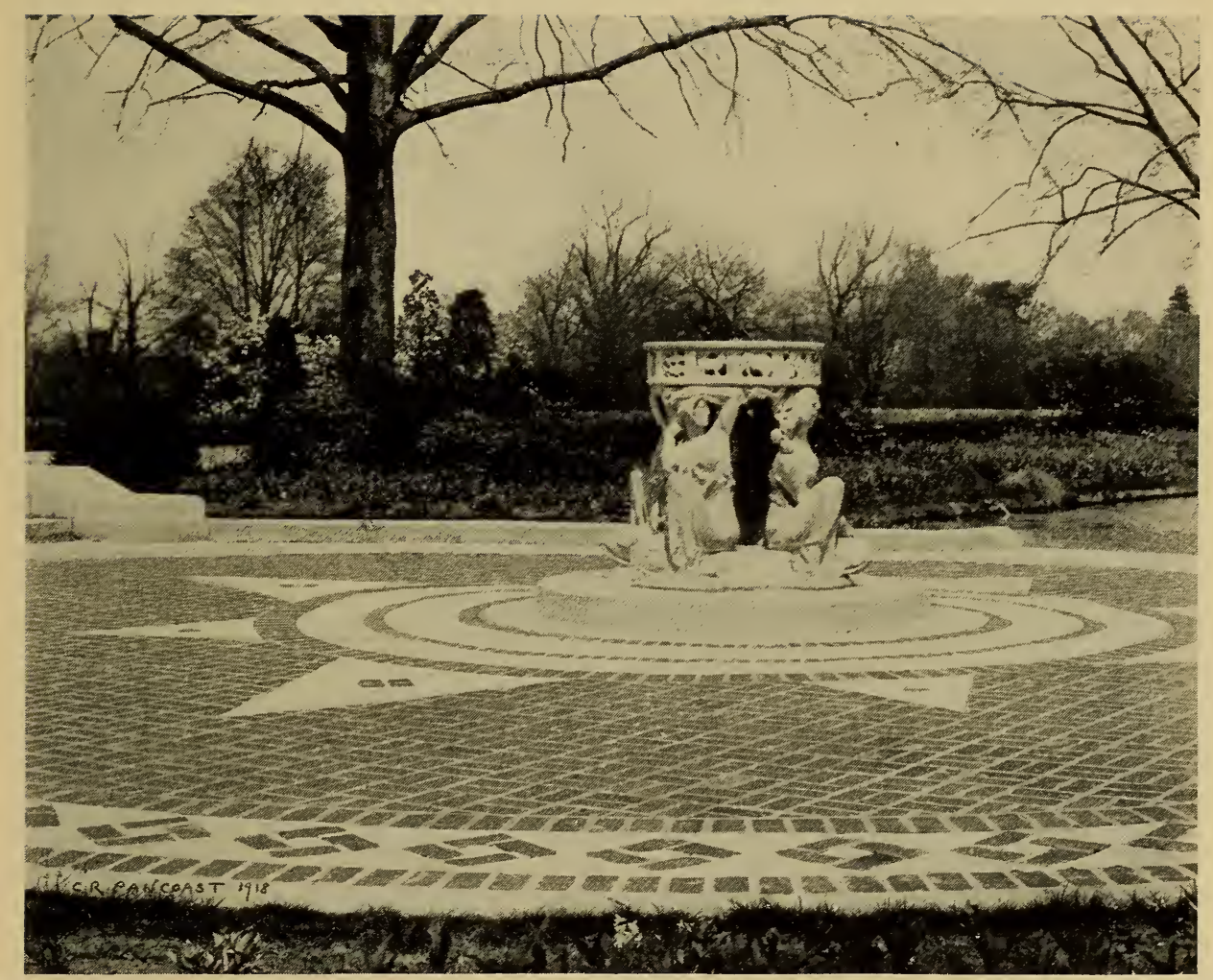

BRONZE SUN-DIAL-by Alexander Stirling Calder

Presented to the City of Philadelphia, through this Association, in 1905, by a member of the Association who desires to remain anonymous. The marble pedestal is the work of Alexander Stirling Calder.

The dial is of bronze, accurately calculated for the exact spot in which it is placed, and shows the variations for each month of the year and the time at 12 o'clock in twelve principal cities of the world.

The design includes the twelve signs of the zodiac, and four supporting female figures, emblematic of the four seasons. 


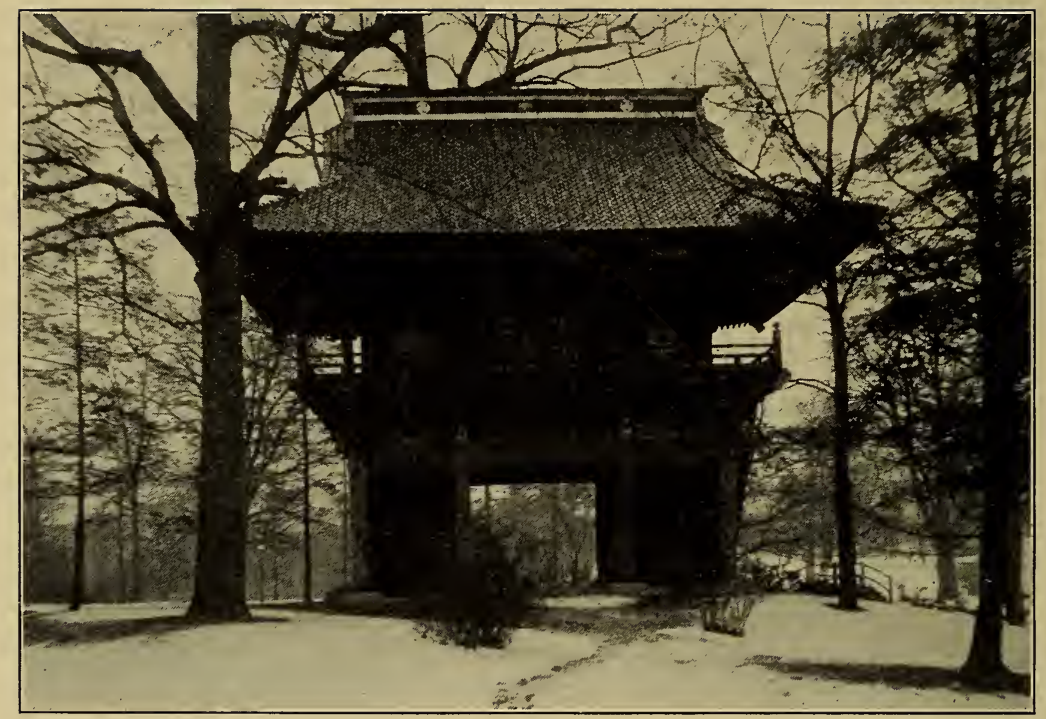

JAPANESE TEMPLE-GATE

(In the West Park, on Lansdowne Drive, near Belmont Avenue.)

Presented to the City of Philadelphia, through this Association, by Messrs. John H. Converse and Samuel M. Vauclain, and erected in the ravine between Memorial and Horticultural Halls in the West Park, near the Lotus-Pond, in December, 1905.

This extremely interesting specimen of the best Japanese work of three hundred years ago, formed part of the official Japanese exhibit at the Louisiana Purchase Exposition in St. Louis in 1904, and was purchased, with its contents, by Messrs. Converse and Vauclain as a gift to the city. The contents of the building, as exhibited at St. Louis, include a superb pair of the usual Temple guardians, Brahma and Indra, and many specimens of Japanese art in wood, metal and fabrics. These objects have been deposited with the Pennsylvania Museum and School of Industrial Art to be exhibited among its collections at Memorial Hall.

The Japanese gardens are a contribution from John H. Converse and John T. Morris. The work was accomplished under the supervision of Mr. Y. Muto, a capable Japanese landscape gardener. 


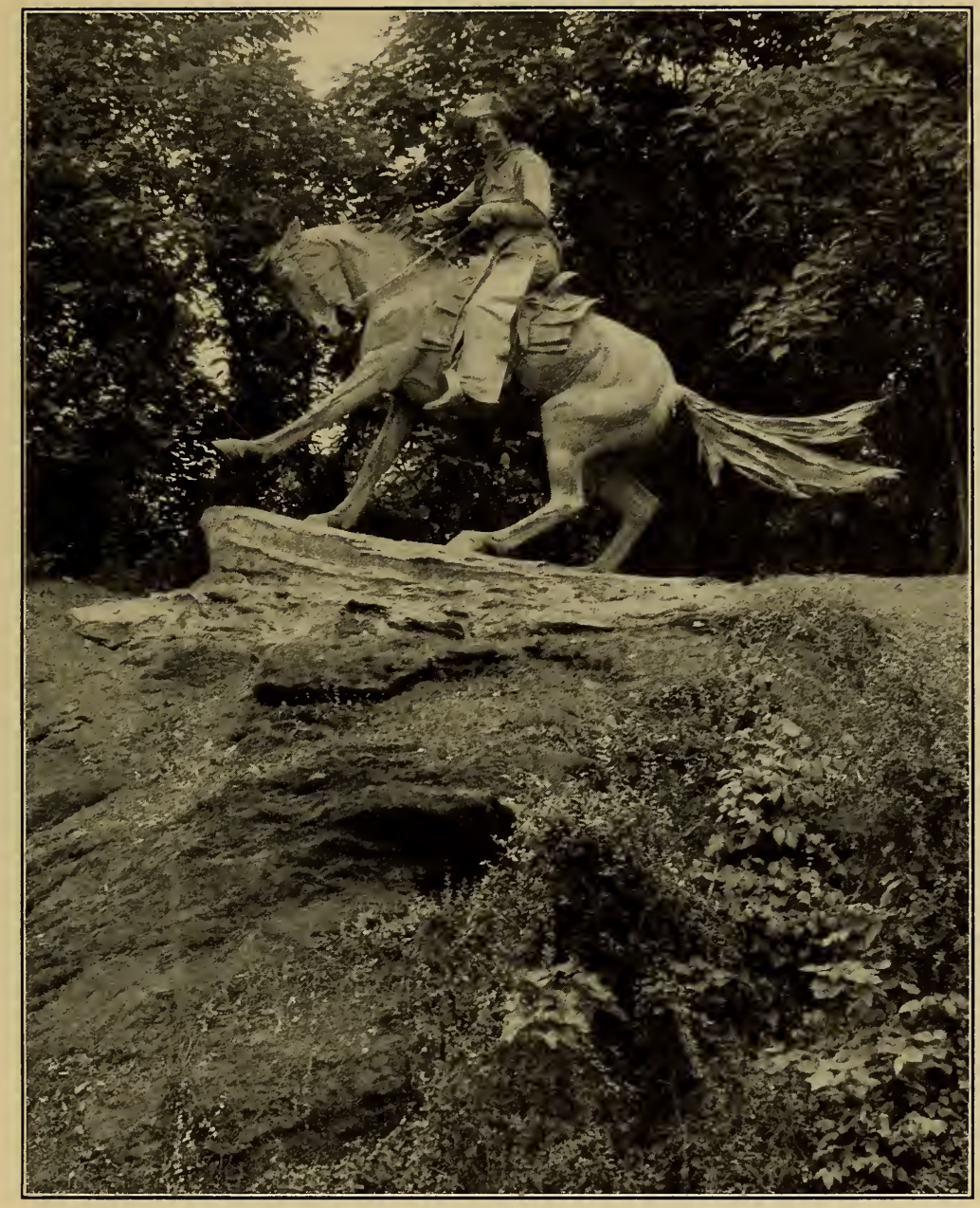

BRONZE EQUESTRIAN STATUE OF COWBOY BY FREDERIC REMINGTON

A Commission from the Association

Placed on the East River Drive in Fairmount Park, north of the tunnel near Girard Avenue Bridge in 1908. 
THIS TABLET IS ERECTED BY THE FAIRMOUNT PARK ART ASSOCIATION

IN COMMEMORATION OF THE FAITHFUL SERVICES RENDERED BY HERMANN JOSEPH SCHW/ARZMANN CIVIL ENGINEER AND ARCHITECT WHO AS PRINCIPAL ASSISTANT AND CONSULTING ENGINEER TO THE COMMISSIONERS OF FAIRMOUNT PARK FROM 1808 TO 1877 DESIGNED MANY OF ITS BUILDINGS BRIDGES ROADS AND OTHER IMPROVEMENTS OF THESE MEMORIAL HALL AND HORTICULTURAL HALL REMAIN TO ATTEST HIS SKILL AND ABILITY $1846-1891$

MEMORIAL TABLET TO HERMANN JOSEPH SCHWARZMANN

To commemorate his services as consulting engineer, 1868-1877. Frected in Memorial Hall, 1915. 


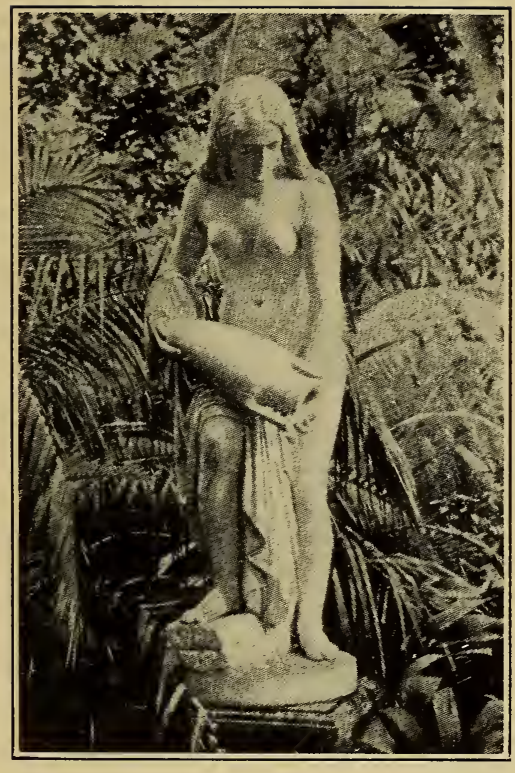

Marble Statue, Copy of the “Danaid," BY RAUCH

Bequest of Paul Griffith

Placed in Horticultural Hall, 1918

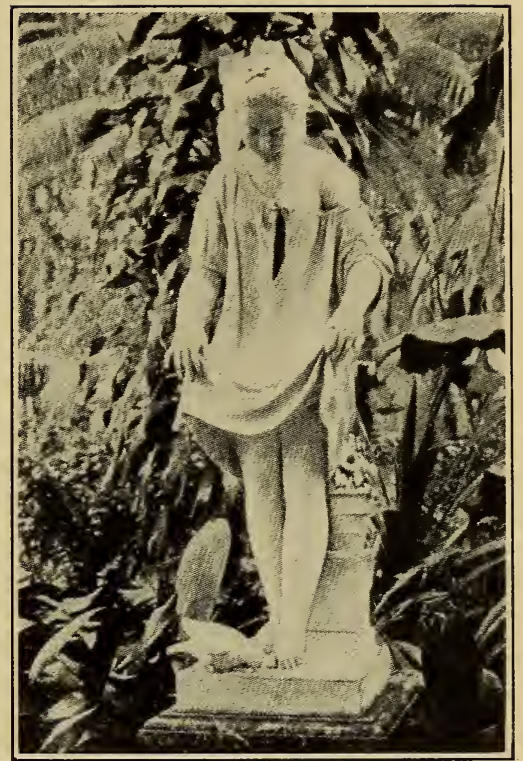

Marble Statue, "Feeding the Doves" Bequest of Paul Griffith Placed in Horticultural Hall, 1918 


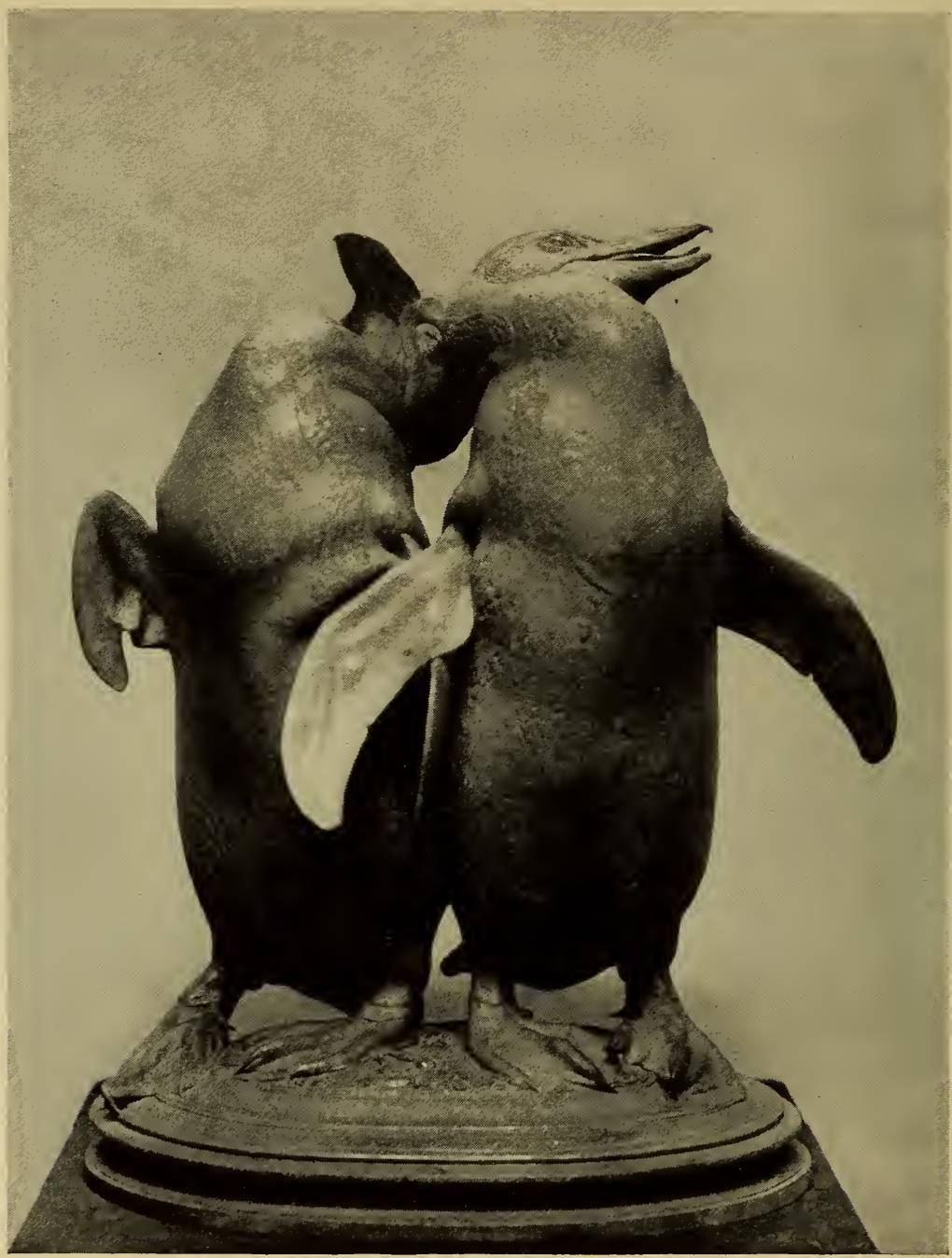

\section{PENGUINS \\ Bronze by Albert Laessle}

Purchased by the Association, 1918. Accepted by the Commissioners of Fairmount Park and erected at the entrance to the Bird House, facing the lake, in the Zoological Garden. 


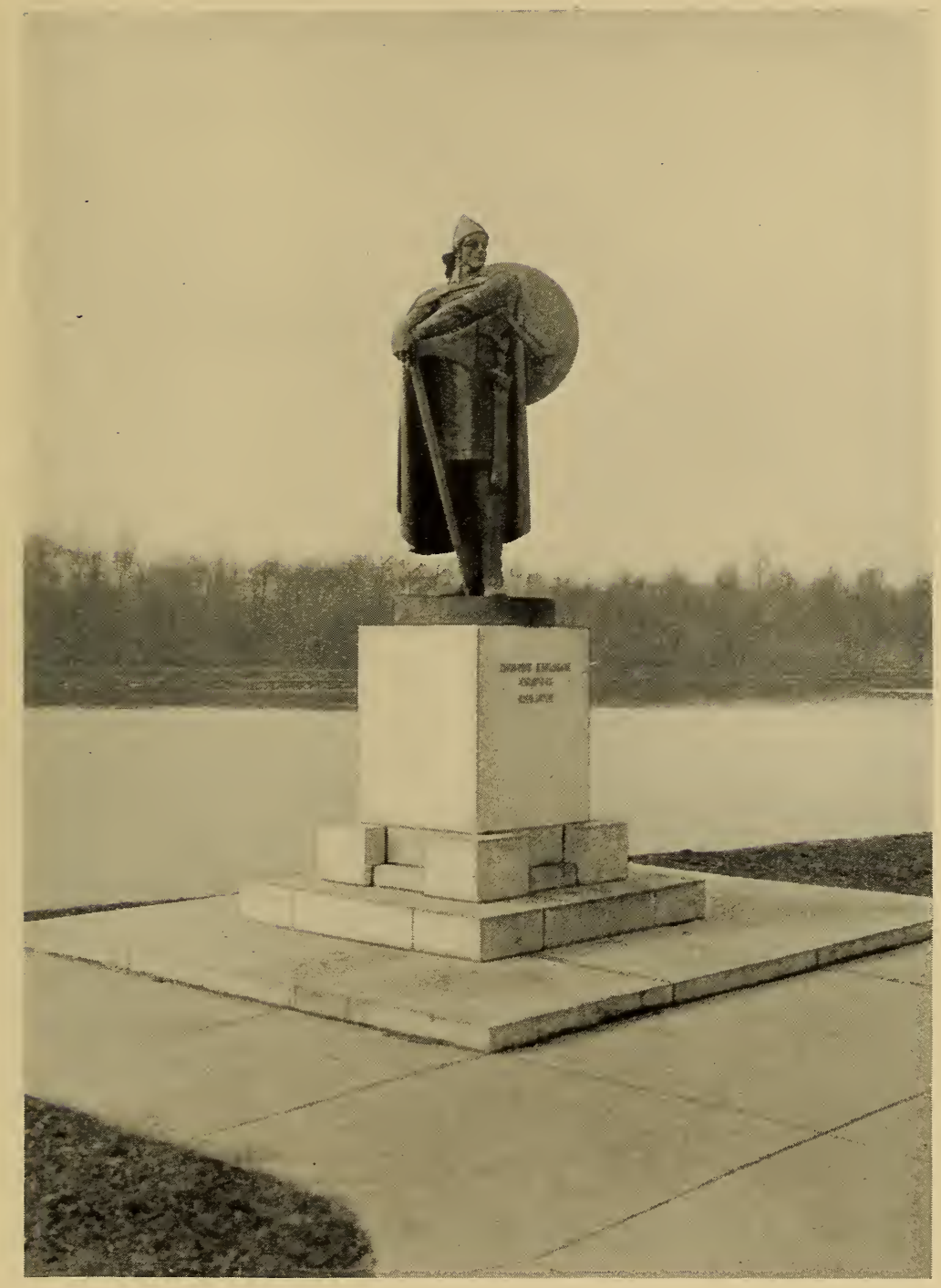

THORFINN KARLSEFNI

Bronze Statue by Einar Fonsson

A gift to the Association by Mr. J. Bunford Samuel, erected on the east bank of the Schuylkill River north of the Sedgley Boat House, 1920. 



\section{WORKS OF ART}

Contributed by or through the CITY BRANCH OF THE ASSOCIATION 


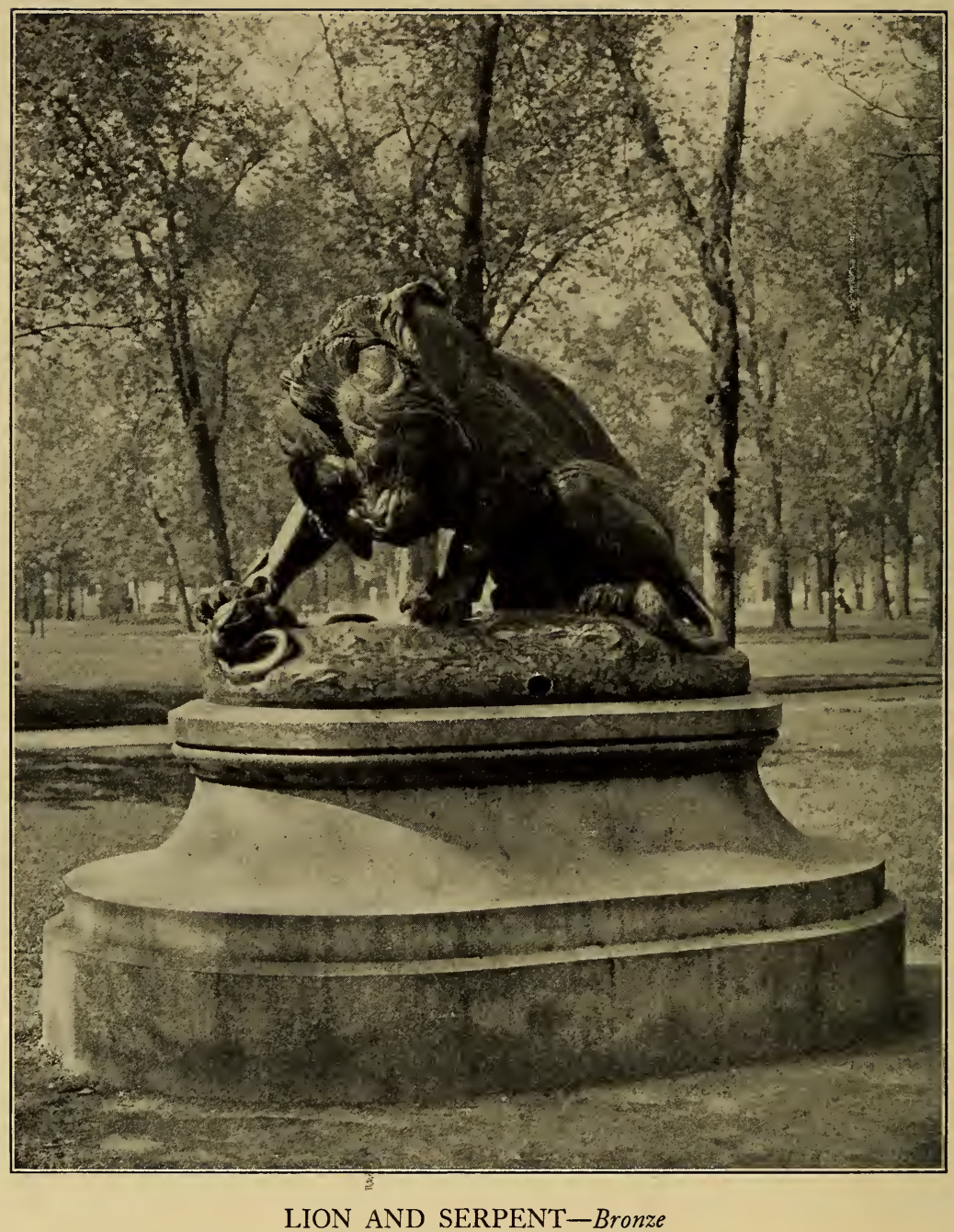
BY BARYE

Purchased by the Association ment.

Replica of one in the Garden of the Tuileries, Paris, by permission of the French GovernPlaced in Rittenhouse Square, 1893. 


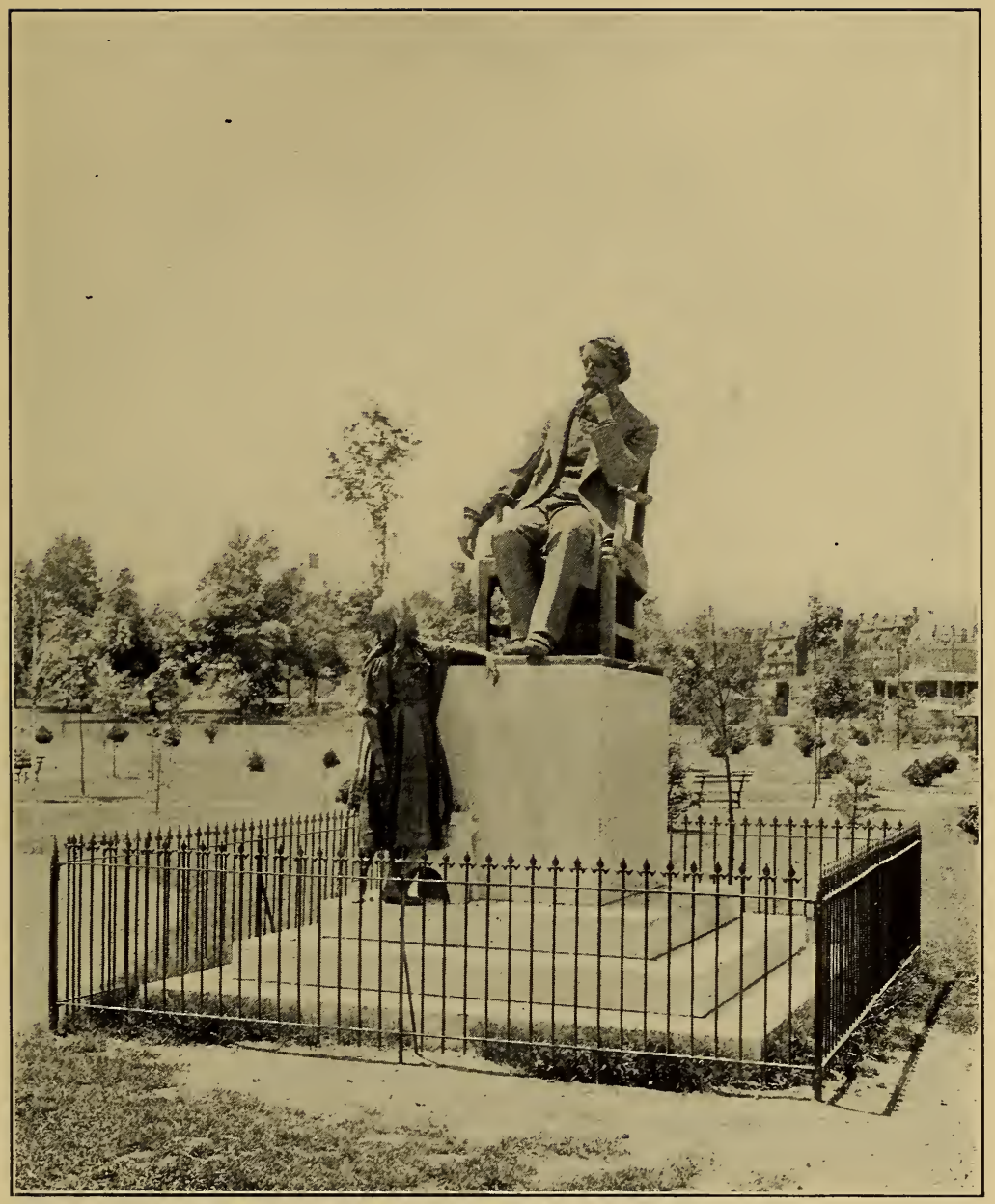

"DICKENS AND LITTLE NELL" $\ldots \ldots \ldots \ldots \ldots \ldots \ldots \ldots \ldots \ldots \ldots \ldots \ldots \ldots \ldots \ldots$ BY F. EDWIN ELWELL

Purchased by the Association

The Little Nell won the Gold Medal of the Art Club, Philadelphia, in 1891. The group was awarded a medal at the Columbian Exposition, Chicago, 1893.

Erected in Clarence H. Clark Park, West Philadelphia, 1901. 


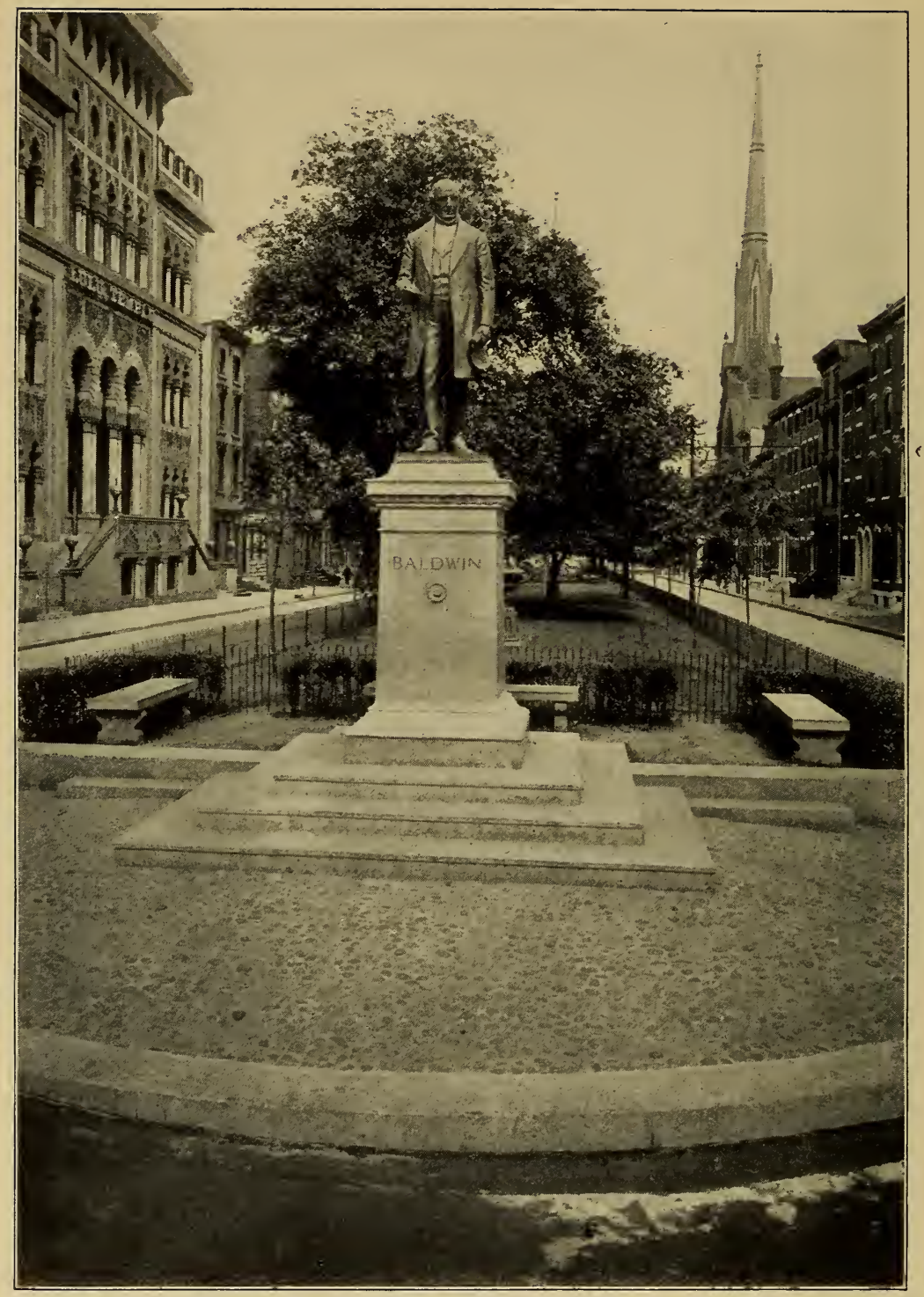

BRONZE STATUE OF MATTHHIAS W. BALDWIN

BY HERBERT ADAMS

This memorial to the founder of the great industry which bears his name, formerly erected in a grass plot at Broad and Spring Garden Streets, was presented to the City of Philadelphia, through this Association, by the firm of Burnham, Williams \& Co., proprietors of the Baldwin Locomotive Works, on June 2, 1906.

Removed in 1921 and placed temporarily on the City Hall Plaza. 


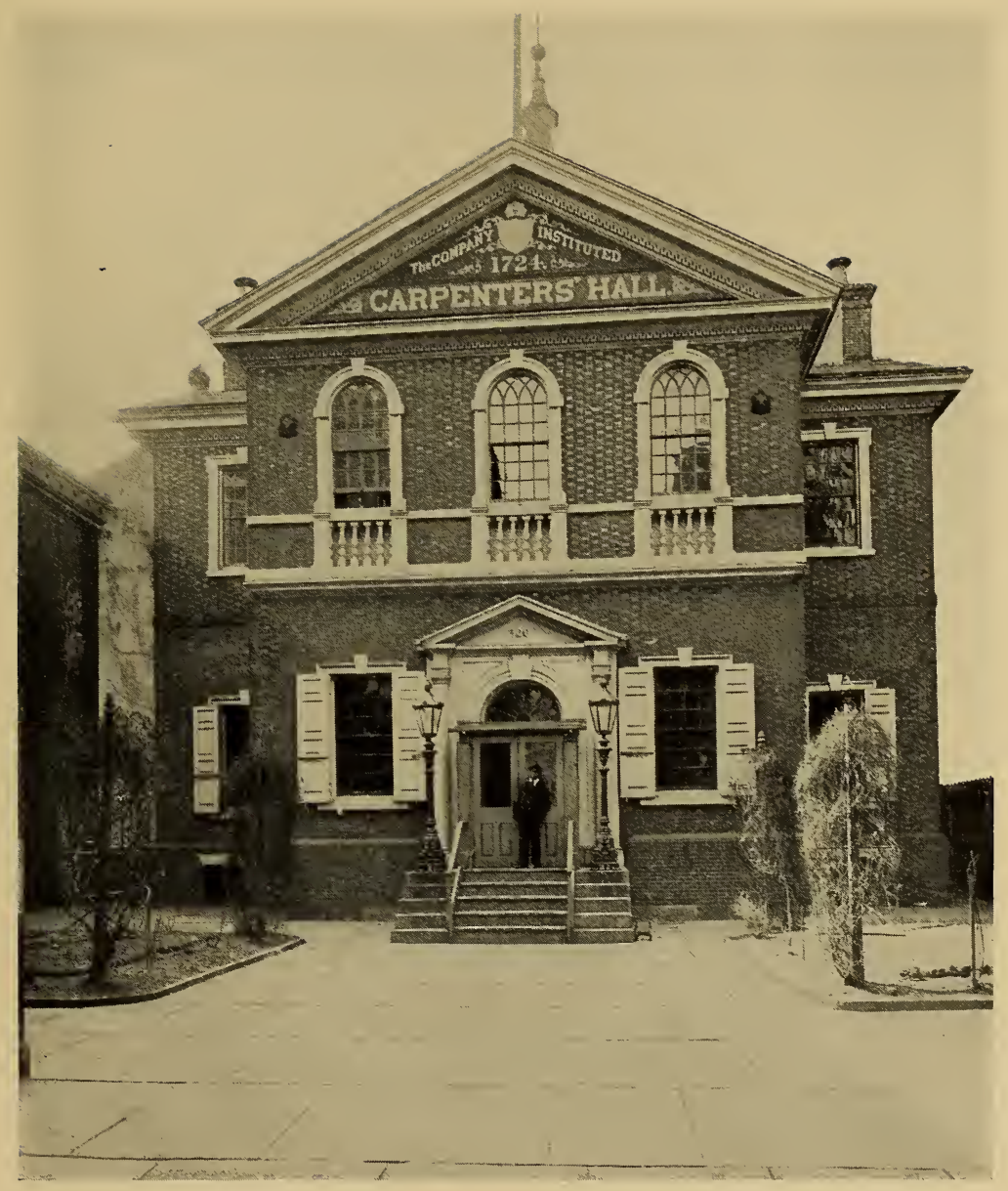

CARPENTERS' HALL

In which the Continental Congress met in 1774. The building of which a portion is seen on the left was acquired by the Fairmount Park Art Association and removed, to avoid the hazard from fire, 1911. 


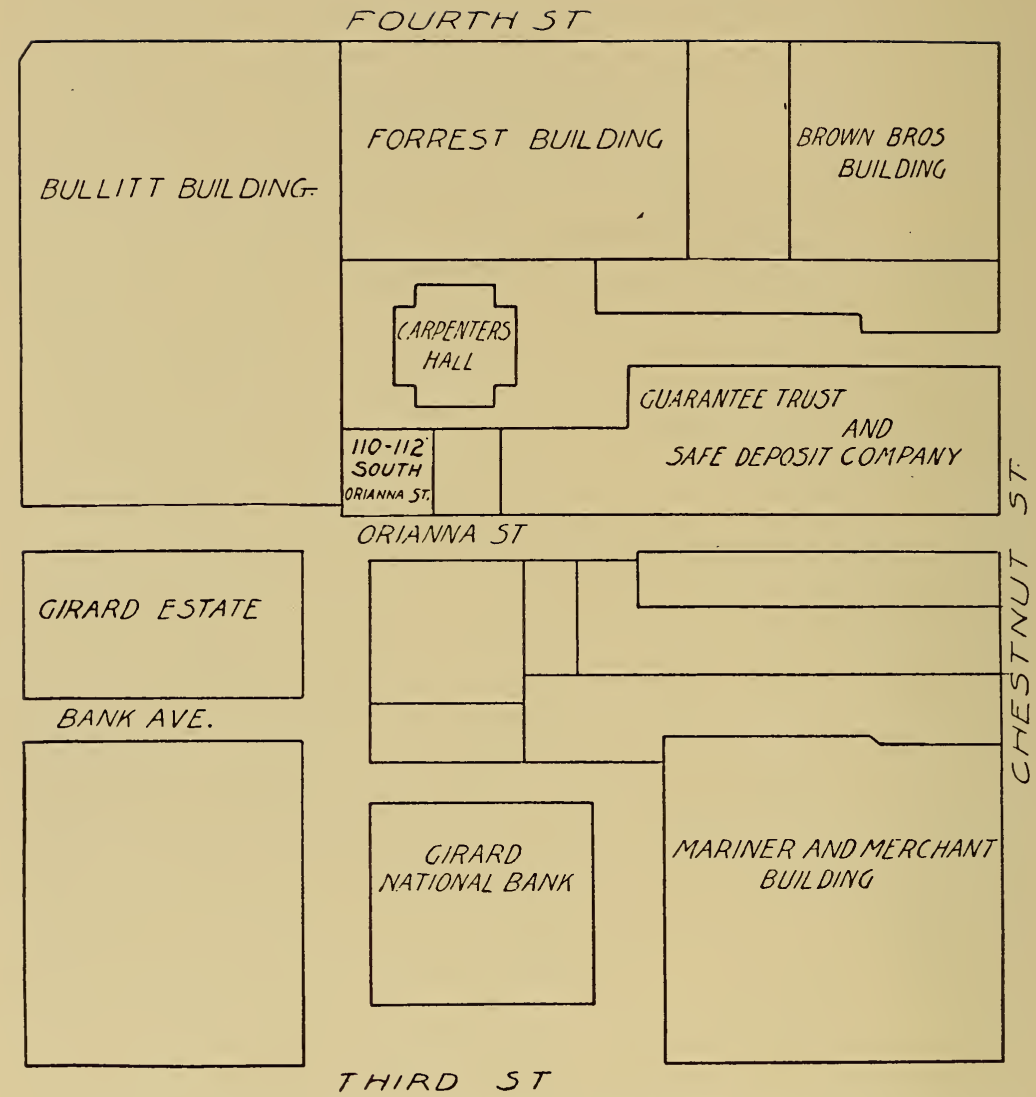

Map Showing Location of Carpenters' Hall and Adjacent Properties

Note the location of property 110-112 South Orianna Street which has been acquired by the Fairmount Park Art Association as an open space for the protection of Carpenters' Hall. 
THIS GROUND PURCHASEO BY THE FAIRMOUNT PARK ART ASSOCIATION WITH FUNDS SUBSCRIBED FOR THIS PISRPOSE BY SEVERAL PATRIOTIC SOCIETIES AND PUBLIC SPIRITED CITIZENS WAS IMPROVEDAS A MEANS OF PROTECTING THE BIRTHPLACE OF AMERICAN LIBERTY CARPENTERS HALL A. D. 1911

Memorial Tablet erected at the entrance to the lot on Orianna street, 1911. 


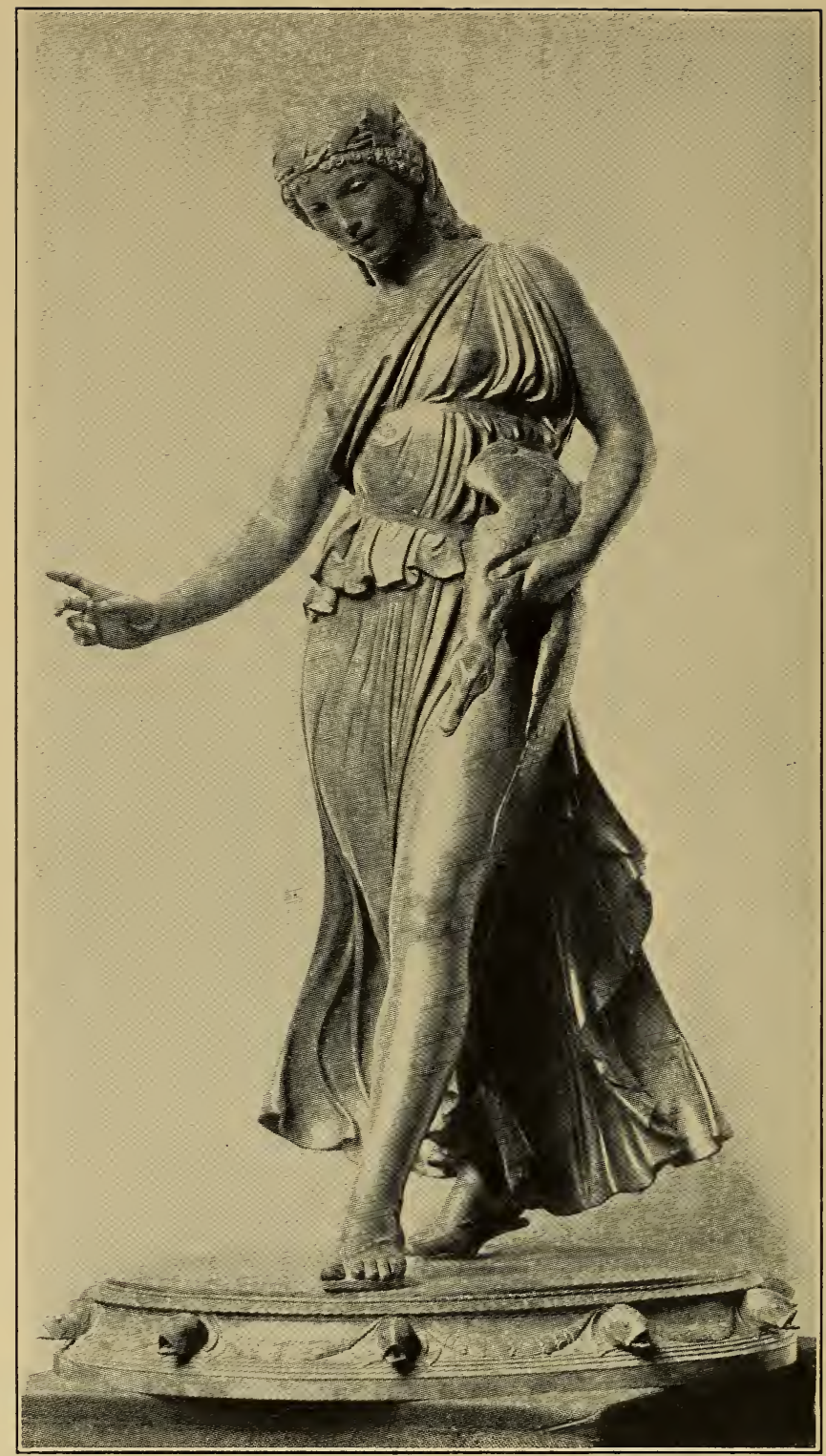

FOUNTAIN FIGURE_-“THE DUCK GIRL."

BY PAUL MANSHIP

This work was awarded the George D. Widener Gold Medal for most meritorious work in Sculpture at the Annual Exhibition of the Pennsylvania Academy of the Fine Arts in 1914. Purchased by the Association and transferred to the Commissioners of Fairmount Park 1916, for erection in "Cloverly," Germantown. 


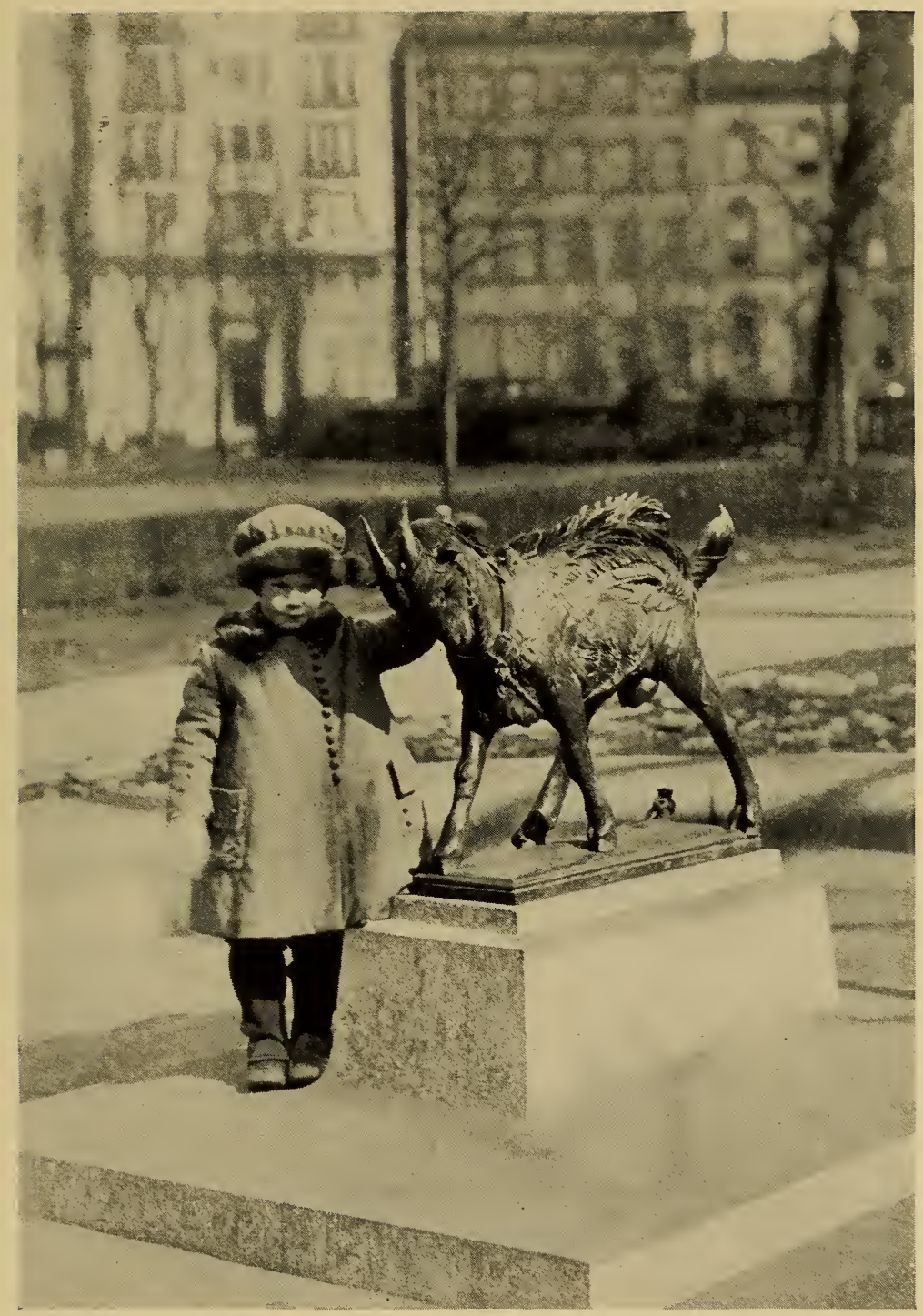

BILLY-Bronze by Albert Laessle

The bronze is a gift to the city by a member of this Association. The Association contributed the pedestal and exedra. Erected in Rittenhouse Square, 1919. 



\section{BRIEF ACGOUNTS \\ of the \\ SCULPTORS \\ BIOGRAPHIES \\ by \\ GHARLES J. COHEN}

In some cases, the sculptors have contributed autobiographies 


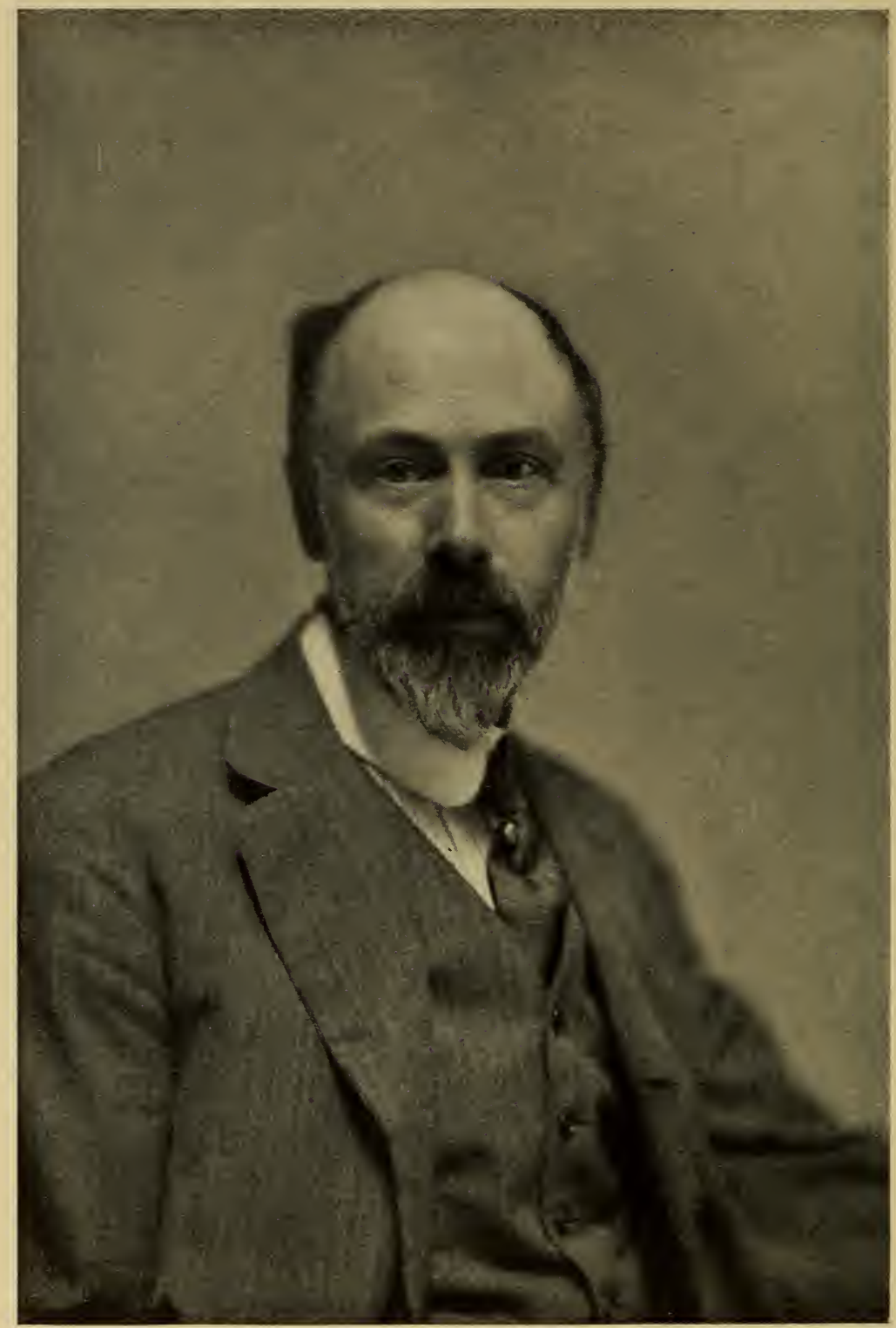

HERBERT ADAMS-Sculptor 


\section{HERBERT ADAMS}

Herbert Adams, born in New England of colonial ancestry, received his early education in Massachusetts, first in the public schools of Fitchburg, then at the Worcester Institute of Technology, and later at the Massachusetts Normal Art School. After a brief period of teaching art classes at the Maryland Institute, he went to Paris, where he studied for five years, chiefly under Mercié and others of the modern French school of sculpture.

On returning to his native country, he took charge of the modeling classes at Pratt Institute and at the same time began work on a series of commissions for the Library of Congress in Washington, including busts, decorative figures, reliefs in oak and in Siena marble, and the rotunda statue of Joseph Henry, the discoverer of important truths in electricity. The statue of Richard Smith, for the Fairmount Park Memorial, soon followed; and, while the Henry was modeled in academic robes, the Smith was shown as a printer, in workman's garb. The Library of Congress doors, that is, one pair of the two originally assigned to Olin Warner, had been entrusted to Mr. Adams after Mr. Warner's death.

Among his statues and monuments are the William Ellery Channing, in the Boston Public Garden; the William Cullen Bryant, New York Public Library; and that of Col. Loammi Baldwin, the eighteenth century Colonel of Engineers, the statue of General Humphreys, Fredericksburg, and that of Jerome Wheelock, Grafton, Massachusetts; the Jonathan Edwards Memorial, at Northampton, Massachusetts; the General Joseph Hawley Memorial, Hartford, Connecticut; the Michigan Soldiers' Memorial, Vicksburg; the MacMillan Memorial Fountain, Washington; heroic statues of John Marshall and Rufus Ranney, also figures of Stephen Langton and Simon de Montfort, for the Cleveland Courthouse.

$\mathrm{He}$ has served on the Municipal Art Commission of New York. He was for some years President of the National Sculpture Society, and Vice-President of the National Academy of Design.

Throughout the World War, Mr. Adams's zeal for our national art was unflagging. He has received many medals from expositions and art societies, among them the Architectural League's Gold Medal for Sculpture. 


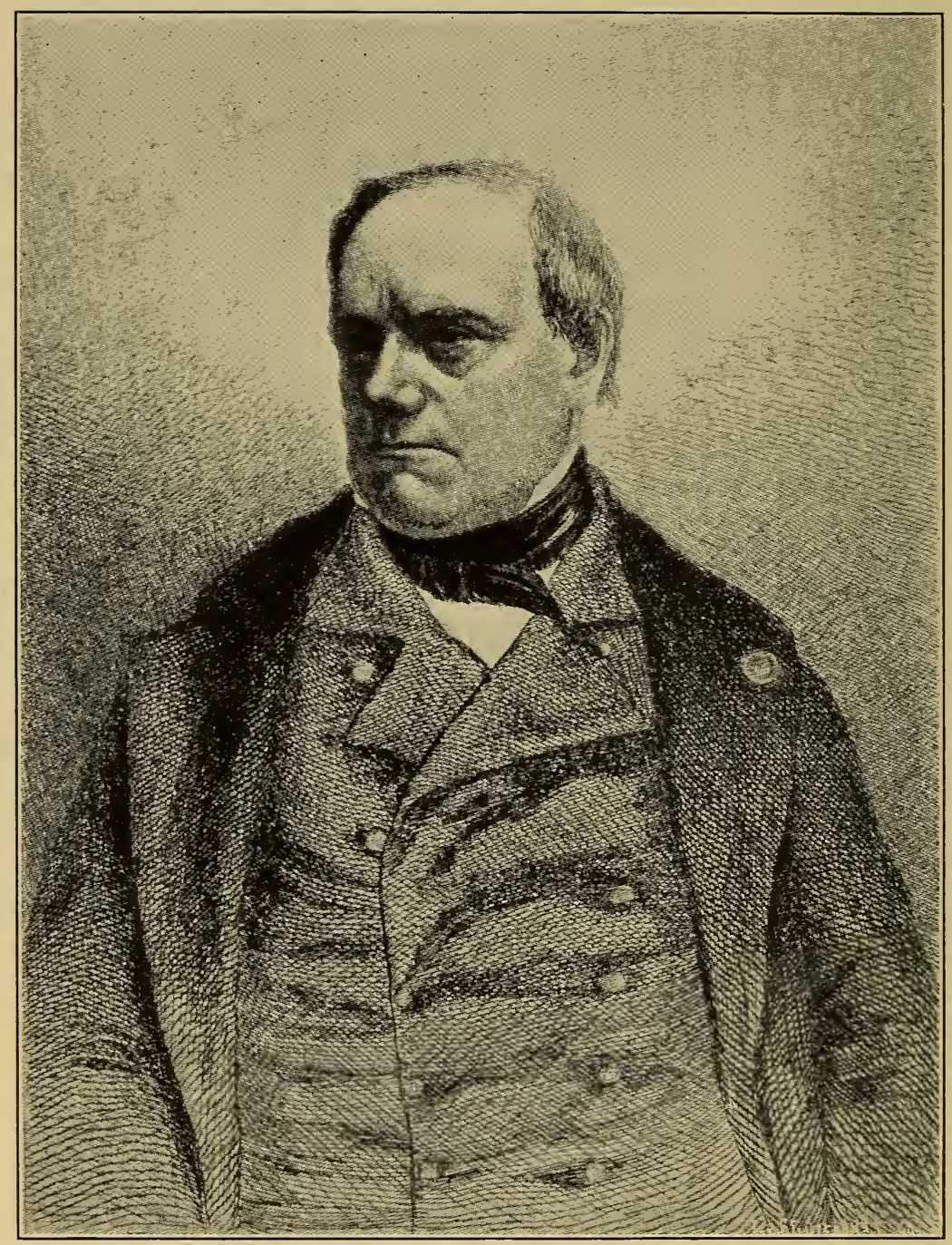

ANTOINE LOUIS BARYE

1796-1875 


\section{ANTOINE LOUIS BARYE}

Born in Paris, 1796. Learned the trade of his father, who was a jeweler. Then studied drawing, engraving, and painting.

Adopted sculpture and created a new school of that art in France. Won fame largely by his works in bronze. Also executed etchings, lithographs, and works in water-color and oil, all highly esteemed since his death. Died in Paris, 1876. His influence on modern sculpture has been akin to that of Millet and his confréres on painting. As in the case of Millet and others of his illustrious contemporaries, Barye received his first substantial encouragement from American collectors. At a time when his works found but negative attention at home, they enjoyed high esteem in the United States. The keynote of his fame in this country was struck when Mr. William T. Walters presented to the city of Baltimore the noble bronzes which are erected in Mount Vernon Square in that city, and when, in 1889, the great Barye Memorial Exhibition was held at the American Art Galleries in New York, the extraordinary variety of the works shown in this display, their diversity of subject, and original power of execution, aroused the admiration of the public as well as the enthusiasm of amateurs. It was a collection of masterpieces, whose majestic merit admitted of no question and which fully justified the dictum of M. Léon Bonnat, the distinguished painter, in the Gazette des Beaux Arts: "Barye is one of the greatest artists of the age, I may even say of all ages." His genius is unique and without a peer and his art has left an ineffaceable stamp upon the world. 


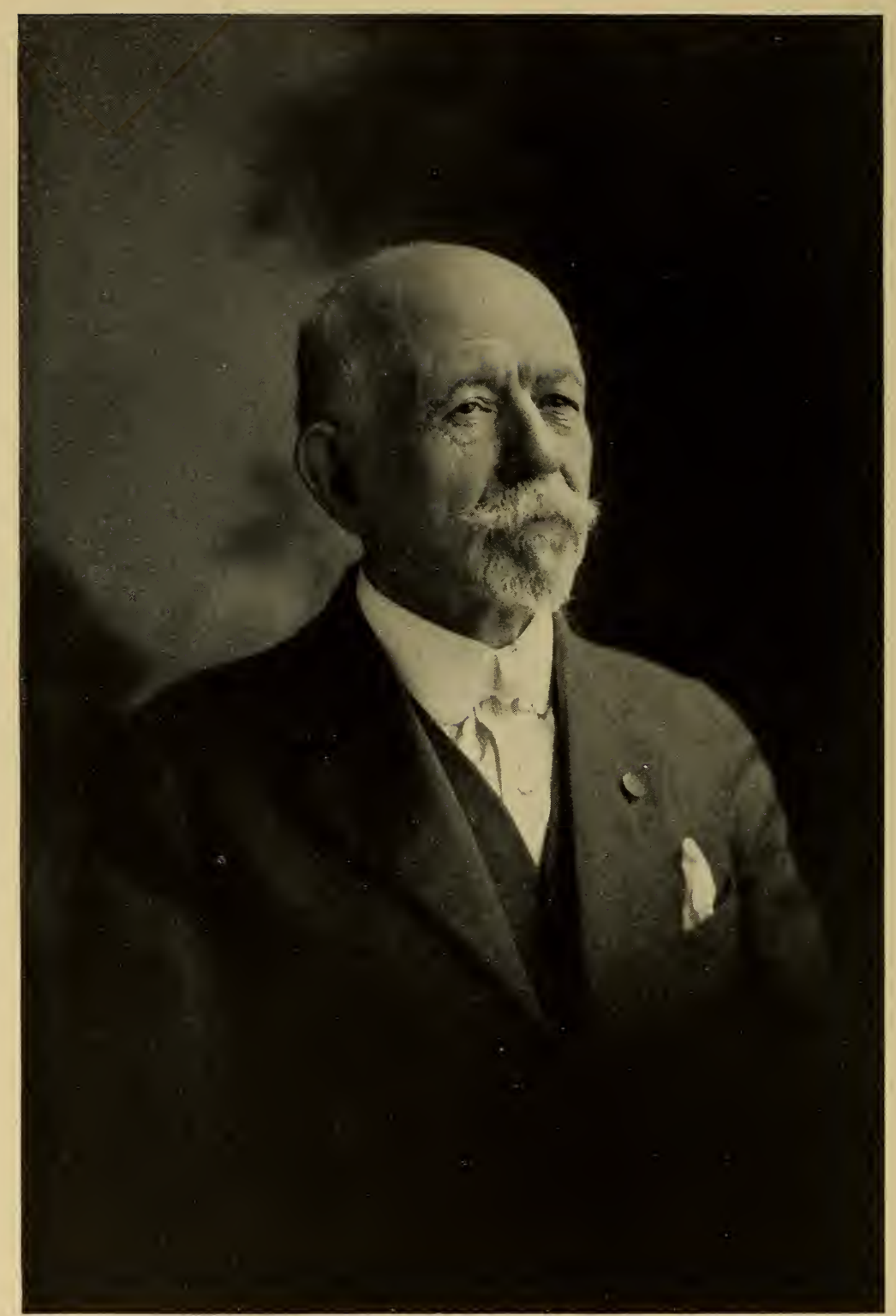

GEORGE E. BISSELI-Sculptor 


\section{GEORGE EDWIN BISSELL}

George Edwin Bissell was born in New Preston, Connecticut, February 16, 1839, and was educated at Northville Academy and at the Gunnery, Washington, Connecticut. He entered the marble business with his father and brother at Poughkeepsie, N. Y., in 1866, subsequently studied art in Paris at different times for about six years, between 1886-96; had a studio in Florence, Italy, 1903-5 and 1907-9. The following public monuments and statues are to his credit: Soldiers' and Sailors' monument, and statue of Col. Chatfield, Waterbury, Connecticut; statue of Gen. Horatio Gates on Saratoga Battle Monument; Chancellor John Watts and Col. Abraham de Peyster, New York; Abraham Lincoln, Edinburgh, Scotland; relief, Burns and Highland Mary, Ayr, Scotland; Chancellor James Kent, Congressional Library; President Arthur, New York; Lycurgus, Appellate Court, New York; group "The Navy," Colonnade Navy Arch, New York; Statue "Hospitality," Buffalo Exposition, 1901; bronze statues of Admiral Farragut and Gen. Sherman; groups "Science and Music," St. Louis Exposition, 1904; statue of Lincoln, Clermont, Iowa; marble bust and bronze statuette in Metropolitan Museum, New York. Member National Sculpture Society. Mr. Bissell died at his home, Mount Vernon, New York, August 30, 1920. 

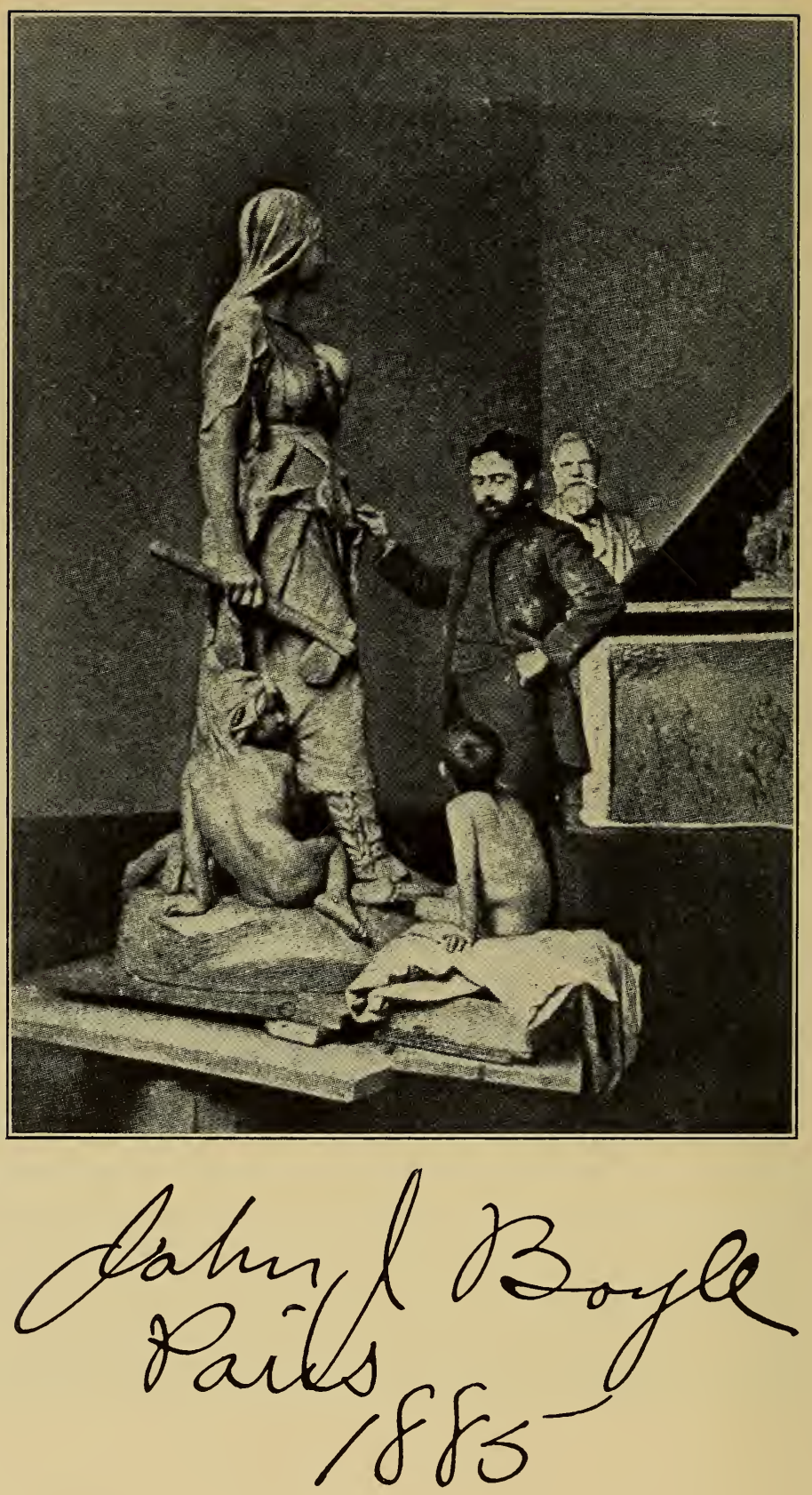


\section{AUTOBIOGRAPHY}

\section{OF \\ JOHN J. BOYLE}

In the parish of St. Stephen's Catholic Church I was christened a few days after my birth in New York City, about the middle of January, in the early fifties.

My father decided to come to Philadelphia, where two of his brothers lived, one an apprentice.

At the age of twenty-one I went in for stone-carving. In the meanwhile I spent some time at drawing school, endeavoring to model, and studying with $\mathrm{Mr}$. Eakins and Mr. Bailey at the Pennsylvania Academy of the Fine Arts. Having saved enough to take me to Paris, I entered the Ecole des Beaux Arts, spending three years there. I made rapid progress, receiving a medal before the end of the second year, and at all times great encouragement from the professors.

At the Salon of 1879 I exhibited a bronze bust, and, besides other work, executed two portraits for Baltimore. In the spring of 1880 I received a commission for the group called, "An Indian Family," and spent two months among the Indians who were to be represented.

When "An Indian Family" was exhibited in Philadelphia, where it was executed, its excellence impressed many, and a feeling prevailed that the Fairmount Park Art Association should have a similar group executed for the Association, and to that end they gave me a commission. This group, "The Stone Age," was begun in Paris in the summer of 1884, exhibited in plaster at the Salon of 1886, receiving a Mention Honorable.

During the summer of 1886 I visited Switzerland and spent eight months in Italy. In $1891 \mathrm{I}$ was asked to go to Chicago and in the spirit in which it was proposed, decided to participate in the great work there.

During the years 1894 to 1895 I finished two statues for the Congressional Library at Washington, those of Sir Francis Bacon and Plato, and, as every artist would feel, was justly proud of the honor conferred upon me by the government. During this time three heroic busts, one for the University of Pennsylvania, one for Bryn Mawr College, and one for the First Unitarian Church, were executed, as were also two portraits for the Hahnemann Hospital and for the Penn Charter School. 


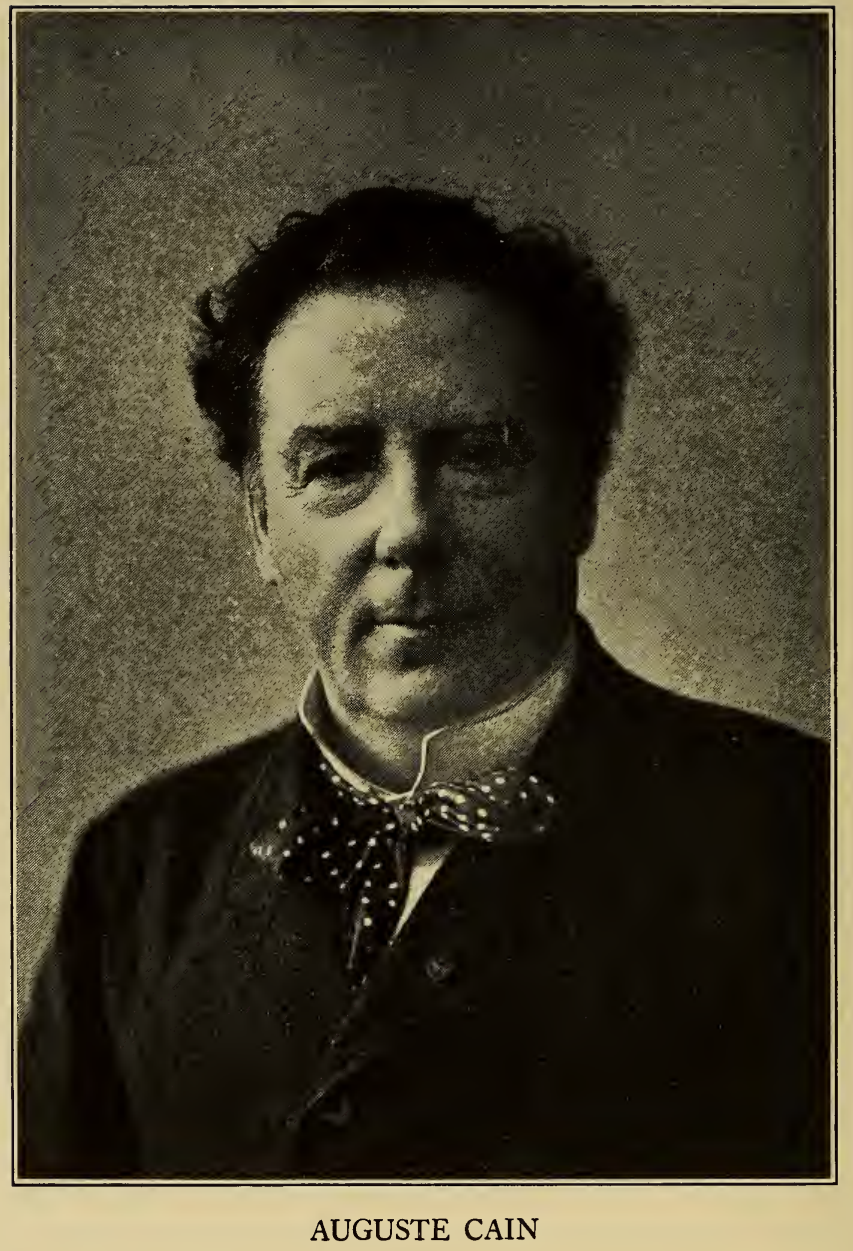




\section{AUGUSTE NIGOLAS GAIN}

Auguste Nicolas Cain closed on August 7, 1894, in his seventy-second year, a long artistic career extending over fifty years, every one of which saw the production of some animal sculpture, which attracted the public taste and lent itself to reproduction. The pupil of Rude and Guionnet, he caught from the former the gleams of dramatic intensity he of ten threw in to the combats of the forest and the tragedies of the field, and he gained from the latter his predilection for animal models: but his real master and true teacher was Barye, and, while Cain's clever modeling never rose to Barye's heroic level, his animal genre was accurate, artistic and interesting. Born in Paris, November 16, 1822, one of the few French artists to see the light in the capital, he was twentyfour when he modeled his "Warblers Defending Their Nest Against a Dormouse." He succeeded this by a comic, "Frogs Selecting a King," and in 1851 he won his first medal in the third class. This was repeated in 1863 and 1864; at the Exposition, in 1867, he had another third class medal, a second class in 1878, and he was made chevalier of the Legion of Honor in 1869, and fourteen years later officer.

As his work became better known, he received commissions for works in connection with the improvements in progress under the Empire about the Louvre and the Tuileries. His "Falcon and Pheasant," 1859, bas-reliefs, ornamented the Louvre; his "Lioness," 1868, the Tuileries, and his "Eagle Defending His Prey" had previously been placed in the Garden of Plants, being an enlargement of an earlier work. From this time he began producing works on a larger scale. In 1870, a "Tiger and Crocodile;" in 1876, the "Tiger's Family," both bronzes, in the Garden of the Tuileries, opposite the Rue de Castiglione; in 1882, a "Lion and Lioness;" in 1884, a "Rhinoceros Attacked by a Tiger," and in 1886, a "Lioness Feeding Her Young," in plaster. The following year he modeled a group of wild dogs for the Elysée. He exhibited a "Lion and Crocodile" in plaster, and he modeled two lions on the gate of the Hotel de Ville, on the side towards the Place Lobau. Besides his work bought by the Fairmount Park Art Association, a "Tigress" is in Central Park, New York; and copies of his "Vulture and Bear," "Lion and Crocodile," and "Tiger Attacking a Rhinoceros," were exhibited at Chicago. 


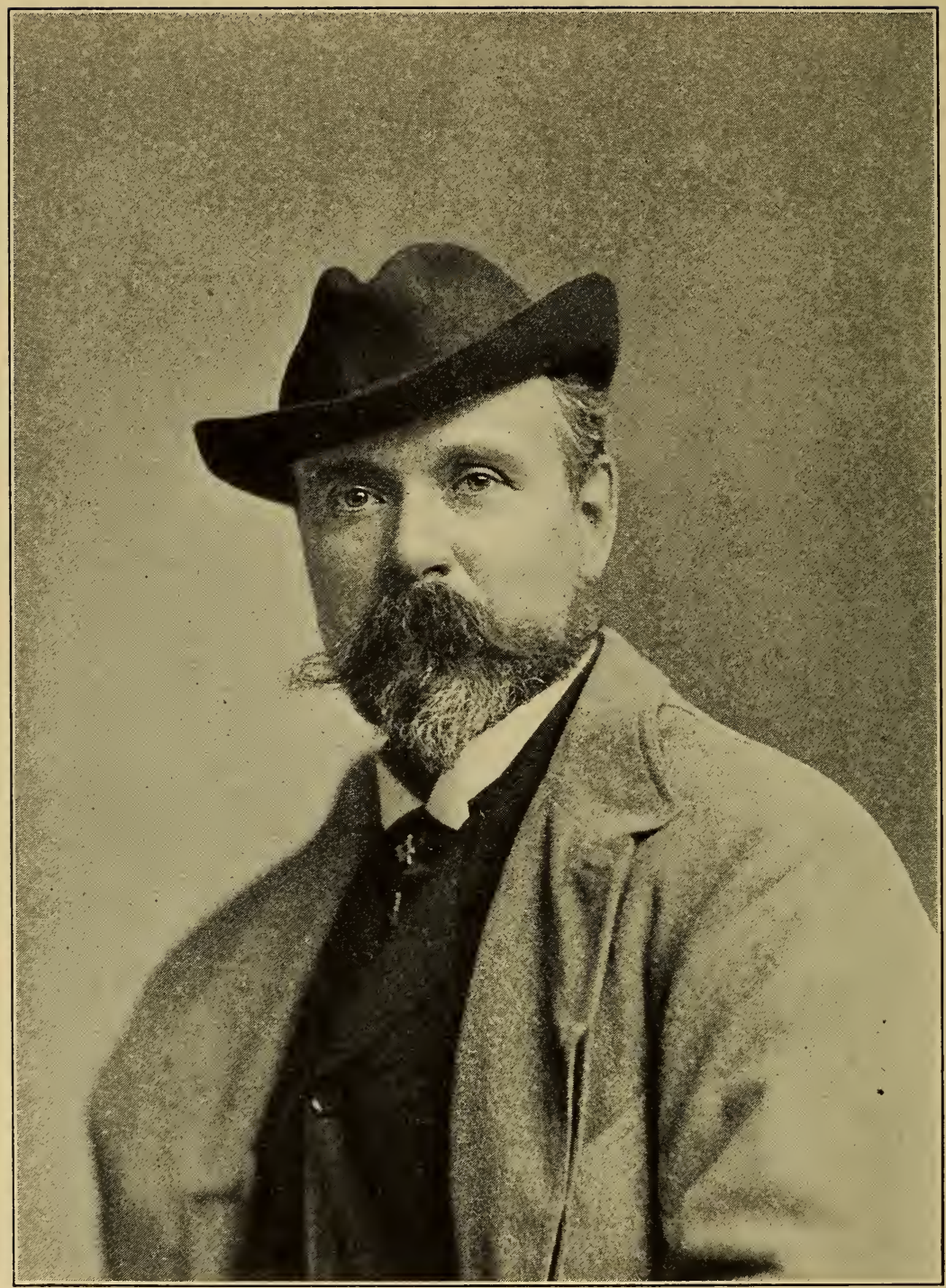

ALEXANDER MILNE CALDER 


\title{
AUTOBIOGRAPHY
}

\author{
$\mathrm{OF}$
}

\section{ALEXANDER MILNE CALDER}

I was born in Aberdeen, Scotland, in 1846. My first work was among plants and flowers, and, seeing a portrait modeled by Brodie, a Scottish sculptor, I went to work in stone, and, in 1864, removed to Edinburgh, to be under the late John Rhind, R. S. A., and became a pupil at the Academy's Schools. After three years I went to London and Paris and, returning to the former city, was engaged on the Albert Memorial, Hyde Park, for a year. In 1868 I came to Philadelphia and became a pupil at the Pennsylvania Academy of the Fine Arts. While modeling for a number of the leading architects of Philadelphia and New York during the next three years, I became a citizen, and, with the exception of a season in New York, have resided in Philadelphia ever since. In 1872 was engaged by the late John McArthur, architect, to design and model groups for the new City Hall. At the Centennial Exhibition, in 1876, I was represented by several figures and a carved panel in stone-birds attacked by a snake-now in the Drexel Institute. In that year, also, the new schools of the Pennsylvania Academy of the Fine Arts were opened and I became a regular student, devoting all my spare time there for the following seven years. In 1877 I removed to a studio in the City Hall, making many designs, historical, allegorical and emblematic, including statues, reliefs, etc., for it, and in 1881 entered into competition for the equestrian statue of General George Gordon Meade, gaining the prize in competition with seventeen other sketches.

Since $1887 \mathrm{my}$ work has mainly been colossal, including the statue of William Penn and groups for the City Hall tower, but I have occasionally made and exhibited several portrait busts and figures, including those of Samuel C. Perkins, General George Gordon Meade and Dr. H. Earnest Goodman for The Union League and the portrait memorials, also in bronze, of the Hon. George Sharswood, the late Chief Justice of Pennsylvania, and of the late John McArthur, architect, and, while occupied with the largest piece, also had the smallest of my work in hand, the Ferdinand D. Hayden Memorial Geological Fund Medal, for the Academy of Natural Sciences. 


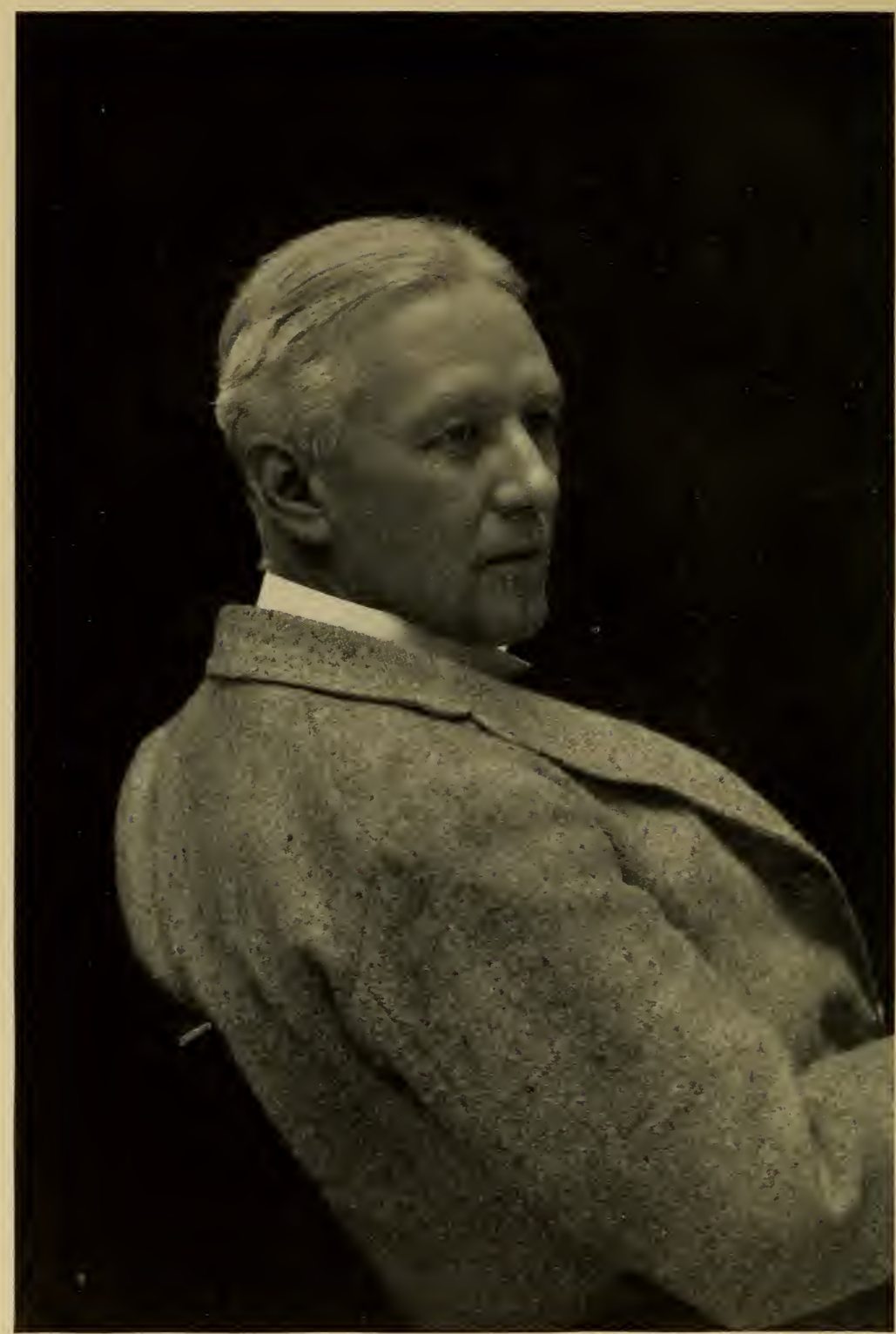

A. STIRLING CALDER-Sculptor 


\section{ALEXANDER STIRLING CALDER}

Alexander Stirling Calder, son of Alexander Milne Calder, was born in Philadelphia in 1870, receiving his early education in the public schools and his earliest art training at the Pennsylvania Academy of the Fine Arts. His first commission, a statue of Dr. Samuel Gross, was won in 1895, whereupon he returned to Paris to execute it, having studied there a few years previously under the sculptors, Chapu and Falguière.

Two more years found him again in Philadelphia where he is at present represented by

The marble Sun-Dial in Fairmount Park

Tribute to a Cellist (Hennig), Academy of Music

Man-Cub, Pennsylvania Academy of the Fine Arts

The Lea Memorial, West Laurel Hill

and several private works.

Across the Delaware in Camden is a remarkable Celtic Cross with original figure decoration, marking the grave of Gen. William Joyce Sewell with bronze grave markers for those of the family dead. The model of this cross, when exhibited at the 100th anniversary exhibition of the P. A. F. A., was acclaimed for its beauty and originality.

In 1912, Calder was appointed Acting Chief of the Department of Sculpture by the Panama-Pacific International Exhibition Company and, having with the late Karl Bitter and the group of architects perfected plans, he removed to San Francisco for the years 1913-1915. His contribution to the ensemble included the Fountain of Energy, the composition of the groups of the "Nations of the East" and the "Nations of the West," the Star Finial, the general design of the Column of Progress, and many other details, as well as the general supervision of the enlargement of the sculpture for the buildings and grounds.

Returning to New York in 1915 he executed the marble group representing Washington as first President of the United States for the western pier of the Arch in Washington Square, the Depew Memorial Fountain for Indianapolis, a composition containing nine bronze figures, and the sculptural decorations for "The Island," a unique feature on the estate of James Deering, Esq., in Miami, Florida. 


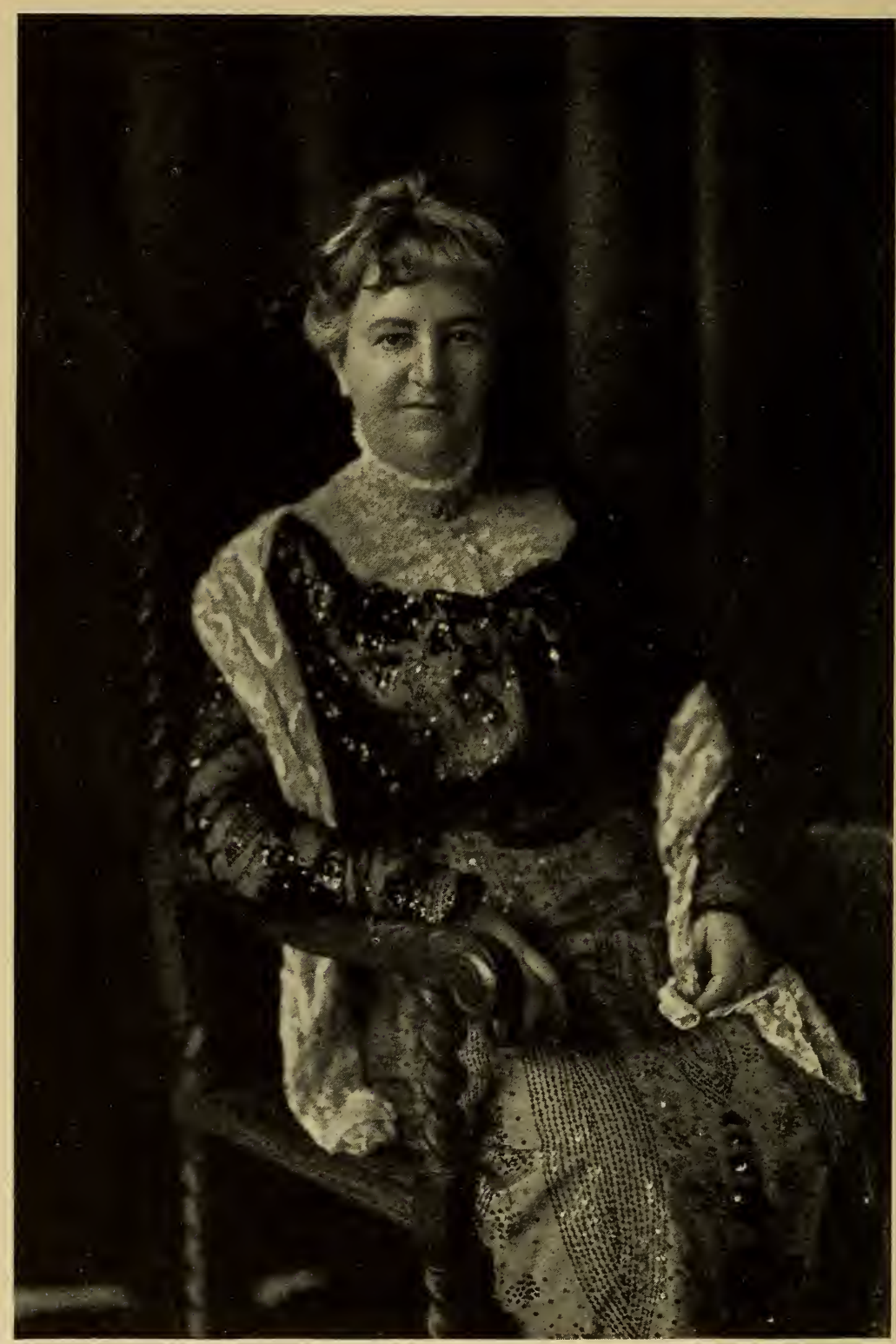

KATHERINE M. COHEN-Sculptress 


\section{KATHERINE M. COHEN}

Katherine Myrtilla Cohen was born in Philadelphia, March 18, 1859. As an artist she ranked high and her studios in her native city, in Paris and in Florence, Italy, were meeting places for men and women who were prominent in art circles.

She began to study art seriously when sixteen years of age, although when much younger she had a taste for drawing, and while attending Miss Dickson's school she was taught this branch by Miss Katherine Drinker, afterward Mrs. Thomas Janvier. At the School of Design for Women, the first regular art school she attended, she studied under Miss Croasdale, Emily Von Trump and Peter Moran. Thence to the Pennsylvania Academy of the Fine Arts, under Thomas Eakins, and to the School of Industrial Art, under John J. Boyle, whom she considered her real teacher in sculpture, Miss Cohen studied the various kinds of art. Besides modeling, she worked considerably in water colors, in which she was instructed for a season by William J. Whittemore, a New York artist, also in a life class at the Art League in New York, under Augustus Saint-Gaudens. She traveled abroad in 1887 and entered the Julien studio in Paris, having previously studied in Philadelphia artistic anatomy under Dr. W. W. Keen.

The group of Rabbi Ben Ezra, which Miss Cohen did in 1887, was exhibited in Philadelphia and New York academies. Among works Miss Cohen exhibited were: "A Moorland Princess" and "Mistress Dorothy," owned by the Hon. H. Fitler; Hon. Mayer Sulzberger, owned by the Jewish Hospital; Cecilia Beaux; Henry Souther and Captain Snow; bas-relief portraits of Carlton T. Chapman, Colin S. Cohen, Mrs. Semple, Dr. Walter M. James, Miss Strater and Mrs. Mary Burnham; decorative modeling in bas-relief, bronze of Lincoln, "Dawn of Thought," "Vision of Rabbi Ben Ezra Expounding the Law," the seal of Gratz College, a portrait of Mrs. Roher, a bust of Dr. William Thomson, now in the building of the College of Physicians, and that of General Beaver, a former Governor of Pennsylvania, placed on the monumental Memorial in West Fairmount Park.

Miss Cohen died in Philadelphia, December 14, 1914. 


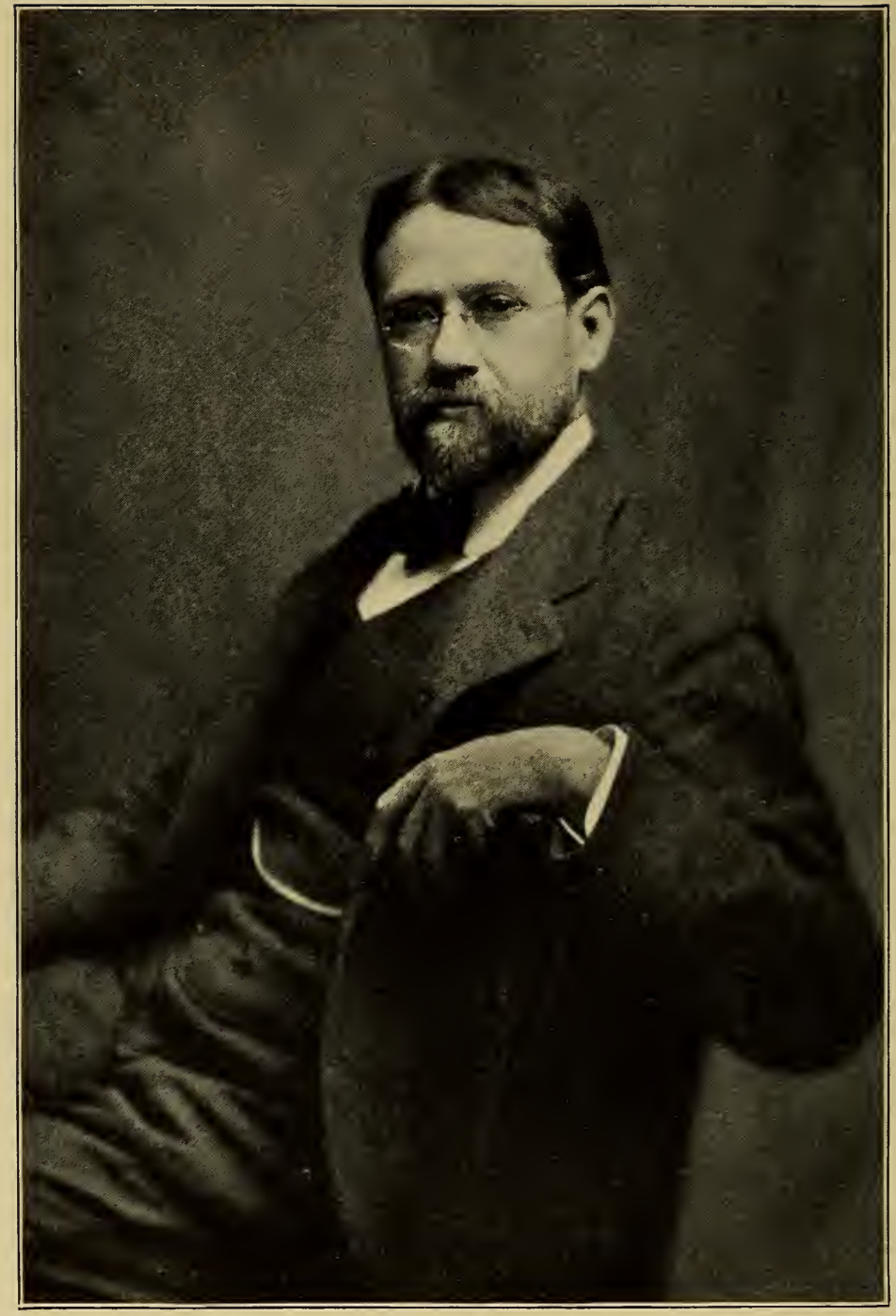

CYRUS EDWIN DALLIN

Sculptor of the "Medicine Man." 


\section{GYRUS EDWIN DALLIN}

Cyrus Edwin Dallin was born at Springville, Utah, November 22, 1861.

In the Spring of 1879 he went to work at one of his father's mines. One day the miners struck a bed of soft white clay, in which he fashioned two life-size heads that attracted such favorable attention at a fair at Salt Lake City, to which they were sent by his admiring friends, that, through the liberality of Mr. Joab Lawrence, means were soon found for sending young Dallin to Boston, where he entered, in the spring of 1880, the studio of Truman H. Bartlett.

In the fall of 1882 he opened a studio in Boston and produced "The Indian Hunter," which was awarded a gold medal by the American Art Association, New York, 1888, "An Indian Chief," "A Cowboy," "A Greaser," and his first design for the equestrian statue of Paul Revere.

In 1888 he went to Paris where he worked under Chapu, and sent to the Salon of 1890 his life-size Indian equestrian statue of "The Signal of Peace," which was presented to the city of Chicago by Judge Lambert Tree. It stands in Lincoln Park, where it was unveiled in 1894.

Other works executed by Mr. Dallin are the statue of John Hancock, for Boston, an equestrian statue of Lafayette, exhibited in Paris in 1889, and equestrian statues of General Sherman and General Reynolds.

After his return to America, he spent three years in his native State, Utah, where he modeled the angel in gilded bronze which surmounts the spire of the Mormon Temple.

After teaching a year at the Drexel Institute in Philadelphia, during which period he also modeled the statue of Sir Isaac Newton for the Congressional Library at Washington, Mr. Dallin spent three more years in Paris (1896-99), where he exhibited his "Apollo and Hyacinthus" in the Salon of 1897, his bronze equestrian "Don Quixote" in 1898, and the "Medicine Man," in 1899.

He received silver medals at the Paris Exposition of 1900, where the "Medicine Man" was accorded an important position, and at the Pan-American Exposition at Buffalo, 1901. In addition to the plaster cast of the "Medicine Man," he was represented at the St. Louis World's Fair by a standing figure of Père Marquette and by a heroic Indian group, "The Protest of the Sioux." 


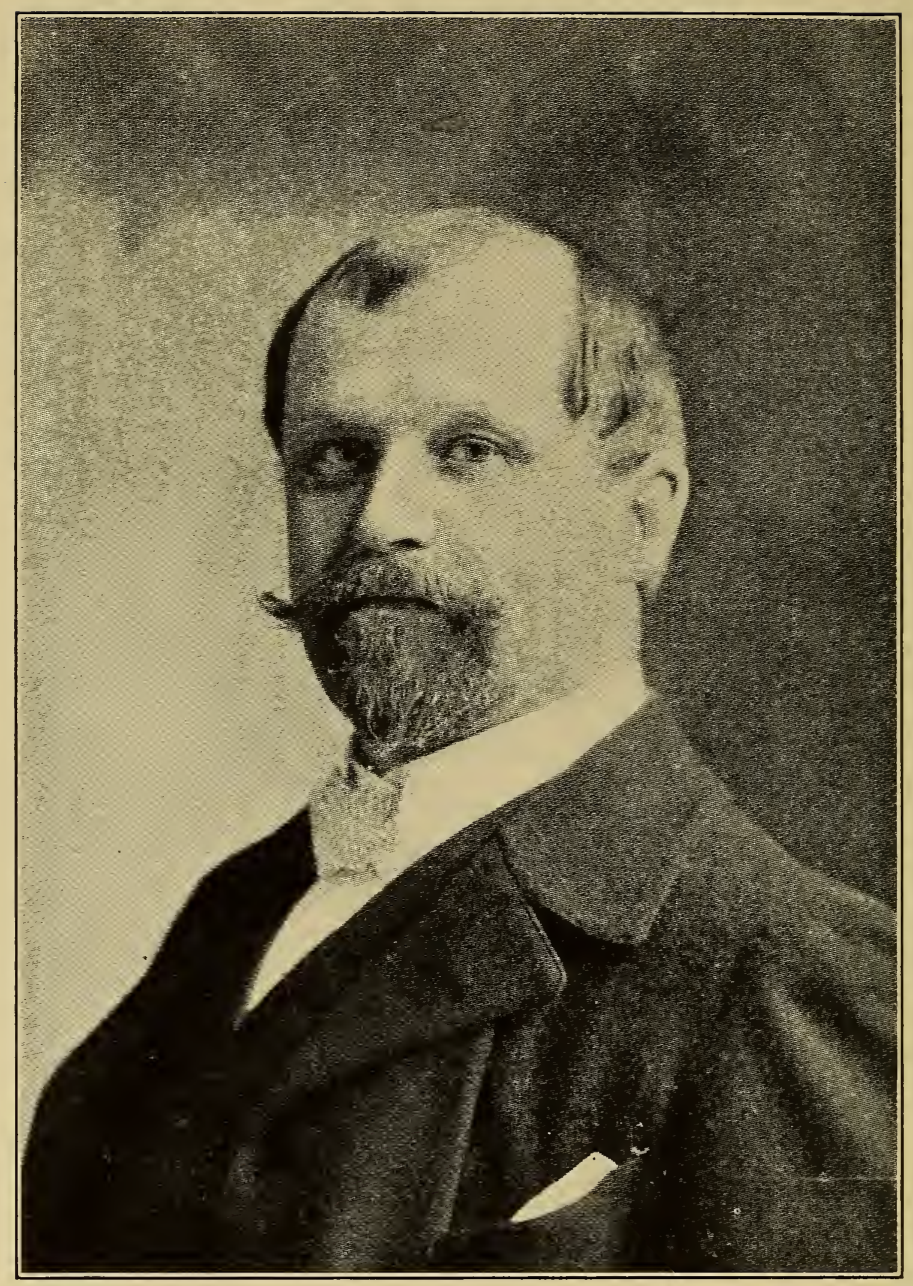

fifturn' Shaceess 


\section{FRANK EDWIN ELWELL}

Frank Edwin Elwell was born at Concord, Massachusetts, on the 15th day of June, 1858. His great grandfather was in the first battle at Concord, April 19, 1775, and his great uncle on the Bruce side was at Bunker Hill.

Mr. Elwell's early life was spent in the town of his birth, with his grandfather, who was the friend of Mr. Emerson, Mr. Channing, Mr. Alcott and Thoreau. Later, Mr. Elwell became a friend of Miss Louisa M. Alcott, and remained in close friendship with her until her death. Miss Alcott took the place of a mother, as his own died when he was about four years old.

Later on Mr. Elwell worked under Mr. Daniel C. French, a neighbor, and then decided to go to Paris. Mr. Levi P. Morton, former Vice-President of the United States, was influential in assisting him to enter the Ecole des Beaux Arts, where he became Vice-President of his class and a private pupil of the renowned Jean Alexandre Joseph Falguière.

On his return to America he made the statue of the "Dying Lion" for Edam, Holland, the "Fountain of Aphrodite," the "Magdalene," and the bust of Mr. Levi P. Morton for the Senate Chamber at Washington. The group of Dickens and Little Nell was modeled at the same time that the statue of "Diana and the Lion" was made. Both took medals at the Chicago Exhibition in 1893, where the group of "Dickens and Little Nell" was accorded a place of honor in the American section of the sculpture department in the Fine Arts Building. The statue of "Diana and the Lion" was placed in the rotunda of this same building and is now in the gallery of Modern Masters, in the Art Institute of Chicago.

While in Belgium Mr. Elwell made the bronze statue of "Aqua Viva," exhibited at the Paris Salon and Royal Academy, London, and now the property of the Metropolitan Museum of Art in New York.

The most interesting of his bas-reliefs are "Saint Vierge," the portrait of Edwin Booth on his tomb at Mount Auburn and the "Young Cleopatra," made in Paris.

His most important work is the equestrian statue of General Winfield Scott Hancock, on the battlefield of Gettysburg, Pennsylvania.

Of all that has come from the hand of this artist there is 
nothing that has received such universal expression of love as the statue of "Dickens and Little Nell."

When the Little Nell was in clay there came a period when it was impossible to go on, the right kind of a face had not been found from which to draw inspiration to finish the work; day after day went by and there seemed to be little advance made. One evening Mr. Elwell was invited to a concert where the music was delightful. As the second part was beginning, Mr. Elwell turned and before him saw the Little Nell of his dreams; gazing long at the charming little girl, he rose and stated to her father that he was making a statue of "Dickens and Little Nell" and that his daughter was the very ideal he had in mind. A few moments later he was at his studio, and worked on into the night, until he had reproduced the spirit of the face he saw at the concert.

When "Little Nell" was exhibited at the Art Club of Philadelphia, it was given a gold medal, the second that had been awarded by the Club.

Later Mr. Elwell went to Paris to continue his study and take up his favorite line of work, that of the Egyptian School of Sculpture. The statue of the "Awakening of Egypt," that was exhibited at the Salon du Champs Elysées and was bought by a French gentleman residing in Paris, was made five times over before there could be reached in any degree the grandeur and subtlety of the Egyptian School. His "Priestess of Isis" was sold in New York by Theodore B. Starr and is considered a remarkable statue. 


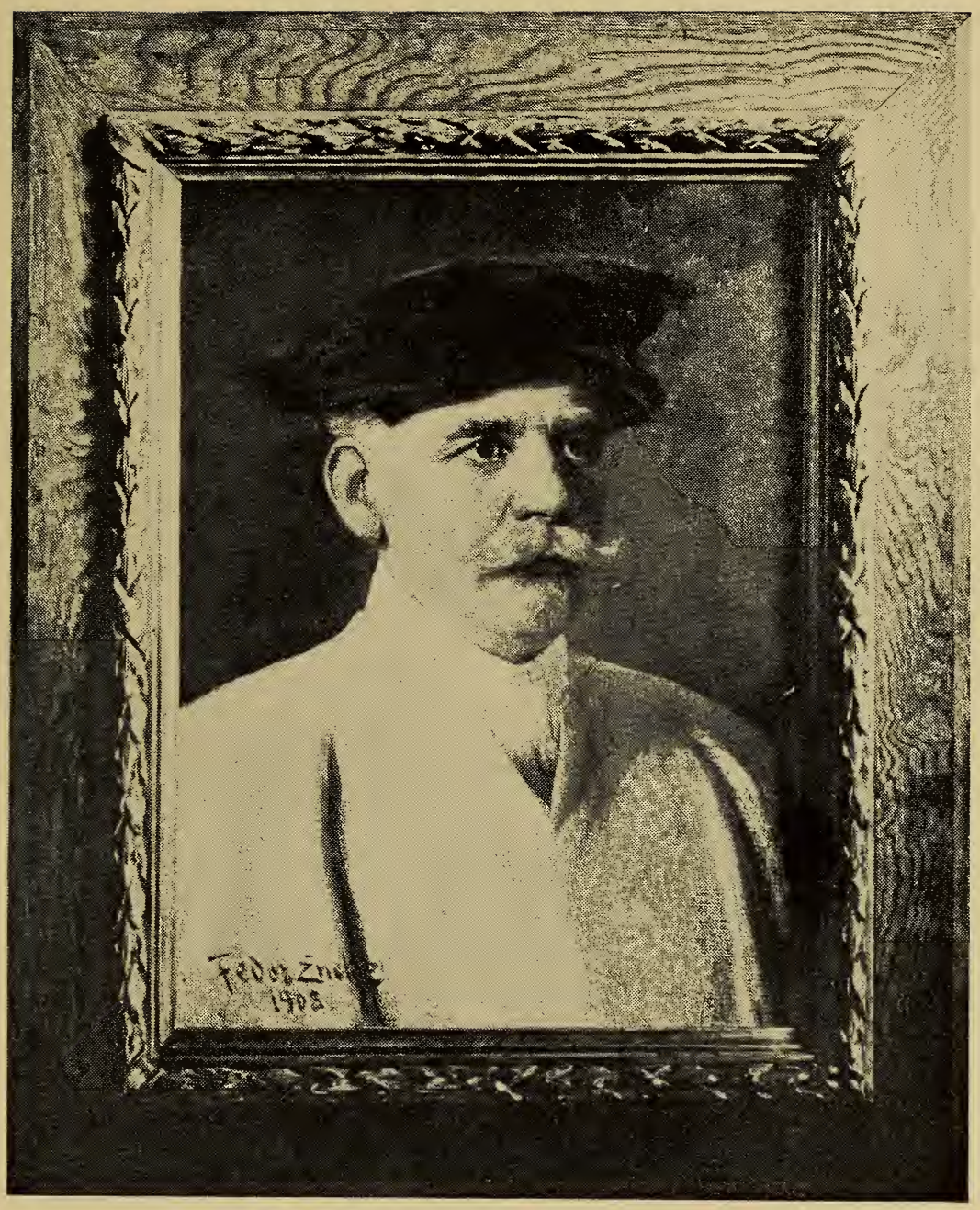

SIR MOSES EZEKIEL-Sculptor 


\section{SIR MOSES EZEKIEL}

Moses Ezekiel was born in Richmond, Virginia, October 28, 1844, and died in Rome, Italy, March 27, 1917.

When a boy of ten he began cutting out little figures for shadow pictures and at fourteen he was devoting his outof-school hours to drawing, painting and writing poetry.

At the breaking out of the Civil War he entered the Virginia Military Institute and participated in the Cadets' defense of Newmarket. He was graduated from the Academy in 1866 and studied anatomy in the Medical College of Virginia.

In 1869 he went to Berlin and studied at the Royal Academy of Art under Professor Albert Wolff. He was admitted into the Society of Artists of Berlin on the merits of his colossal bust of Washington and was the first foreigner to win the prize of Rome. This was in 1873.

These were lean years for the struggling young artist and he supplemented his income by acting as correspondent in the Franco-Prussian War. He was arrested and imprisoned for a time as a French spy. When liberated he returned to Berlin and from that time on his life became one of success. He went to Italy in 1874 and lived there until his death.

The sculptor occupied a magnificent studio in the Baths of Diocletian and his palace, which was stored with articles of art, was one of the show places of the Eternal City. One of his earliest acquaintances was Cardinal Hohenlohe, of Germany, and through him he met Franz Liszt, the composer, of whom he became a pupil. He made a bronze bust of Liszt for the Cardinal. For the Grand Duke of Saxe-Meiningen he made copies of his busts of Liszt and Hohenlohe. For these he received two royal decorations giving him the standing of a knight.

His first important work was "Religious Liberty," a marble group shown at the Centennial Exposition and later placed in Fairmount Park, Philadelphia. Another monument to his art is "Virginia Mourning Her Dead," for the Virginia Military Institute, Lexington.

Among the many examples of his work in this country are the bust of Washington in the Cincinnati Art Museum; "The Sailor Boy," "Grace Darling," and "Mercury," owned by Mrs. Hannah E. Workman, of Cincinnati; the statues of Phidias, Raphael, Dürer, Angelo, Titian, Murillo, Da Vinci, 
Correggio, Van Dyke, Canova, and Thomas Crawford, the designer of the Washington Monument, which adorn the Corcoran Art Gallery in Washington, D. C.; the bronze bust of Robert E. Lee, H. C. Ezekiel of Cincinnati, bas-reliefs of "Pan" and "Amor" for Mrs. Charles Fleischmann, of Cincinnati; marble torso "Judith" for Mrs. Bellamy Storer; marble bust of "Christ" for J. N. McKay, of Baltimore, bronze bust of General Hotchkins in the Navy Yard at Washington, marble statue "Lee a Boy" for the village of Westmoreland; a monument to Jesse Seligman at the Jewish Orphan Asylum, New York; a colossal statue of Columbus, Columbus Memorial Building, Chicago; heroic bronze monument to Thomas Jefferson at Louisville; and "The Outlook" for the Confederate Cemetery at Johnson's Island, Ohio. He also executed the Fountain of Neptune for the City of Netturno, Italy, and the bust of Governor Curtin for the Monumental Memorial in Fairmount Park.

Sir Moses Ezekiel was decorated by a former German Emperor with the Cross of Merit and Art, and by the late King Humbert and the present King Victor Emmanuel.

On a visit paid by the sculptor to America in 1910, he was present at the unveiling of three statues he had executed, one a bronze of Stonewall Jackson for Charlestown, West Virginia, another of Jefferson for the University of Virginia, and another to the memory of Confederate prisoners who died on Johnson's Island, Ohio.

His most important work in Philadelphia is the statue of the late Anthony J. Drexel in Fairmount Park, the gift of John H. Harjes, of Paris.

In the year 1911 Ezekiel spent several weeks in Philadelphia as the guest of friends and attended a reception given by the Musical Art Club in his honor.

The last visit of the sculptor to Philadelphia was in 1913, when he came to this country to attend the unveiling of his monument to the Confederate dead in Arlington Cemetery, at which President Wilson made the chief address.

A noted Roman citizen wrote "The death today of Moses Ezekiel, the distinguished and greatly beloved American sculptor, who had lived in Rome for more than forty years, caused universal regret here. His death occurred in his unique apartment, artistically arranged by him in the Tower of Belisarius on the ancient walls of Rome."

His last work, a statue of Poe, was erected in Baltimore. 


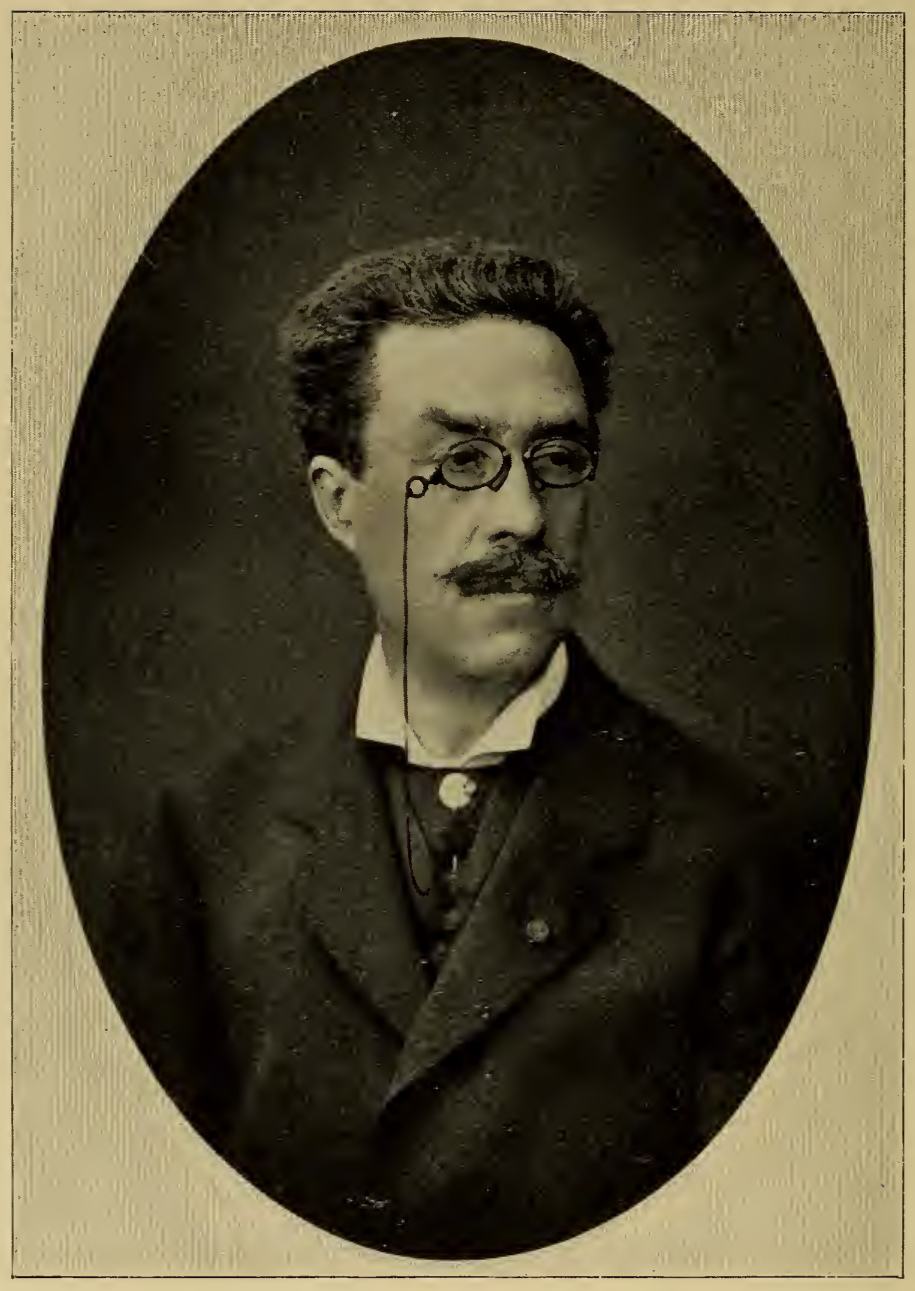

EMMANUEL FRÉMIET 


\section{AUTOBIOGRAPHY \\ OF}

\section{EMMANUEL FRÉMIET}

Translated by Chevalier Louis Vossion, French Consul at Philadelphia

I was born at Paris, the 15 th of December, 1824. The beginning of my life was spent in great poverty; but, as metal is tried by fire, so do the artists find generally their talent, if possessing any, tested by the intensity of the hardships and difficulties they have to encounter; and for such severe testing as I have experienced I am to-day most grateful.

I was a nephew of the celebrated sculptor, Rude, the author of the bas-reliefs of the Arc de Triomphe at Paris, in whose atelier I studied for several years.

My first appearance at the Salon de Paris dates from 1843 and since I have exhibited yearly, almost without interruption. My principal works have been the following: Salon of 1843, "A Gazelle," study in plaster; 1847, "A Dromedary;" in 1850, "A Wounded Hunting Dog," in 1853, "The Horse of Montfaucon," which was bought by the French Government; at the Universal Exposition of 1855, five statuettes: "Carabinier," "Gunner on Horseback," 'Voltigeur," "Gendarme on Horseback," and "Brigadier des Guides"-forming part of a collection ordered by Napoleon III and completed in 1859 by "Cent-Garde," - "Gunner of the Guard," "Zouave of the Guard," "Miner," and "A Trooper's Horse," at the Un versal Exposition of 1867, "A Roman Cavalier," "Napoleon I," bronze equestrian statue for the castle of Pierrefonds; "Joan of Arc," a plaster statue different from the equestrian one of the same heroine erected in 1874 on the Place des Pyramides at Paris; then later on, "St. Gregory of Tours," marble statue for the Pantheon; "The Great Condé," equestrian statue in bronze; "Stephen, the Great," for the city of Jassy, Roumania; in 1882, "Porte-Falot on Horseback," for the Hôtel de Ville, of Paris; in 1883, "Charles V," for the National Library of France; in 1885, "Race Horses," bronze groups; in 1888, an "Equestrian Statue of St. Louis," and "L'Incroyable," a bronze statuette; and a "Statue of Velasquez;" "Donkeys of Cairo;" bronze "Statue of St. George," and others.

When Barye, the great sculptor, died, I had the honor to succeed him as professor of design at the Museum of Natural History. 


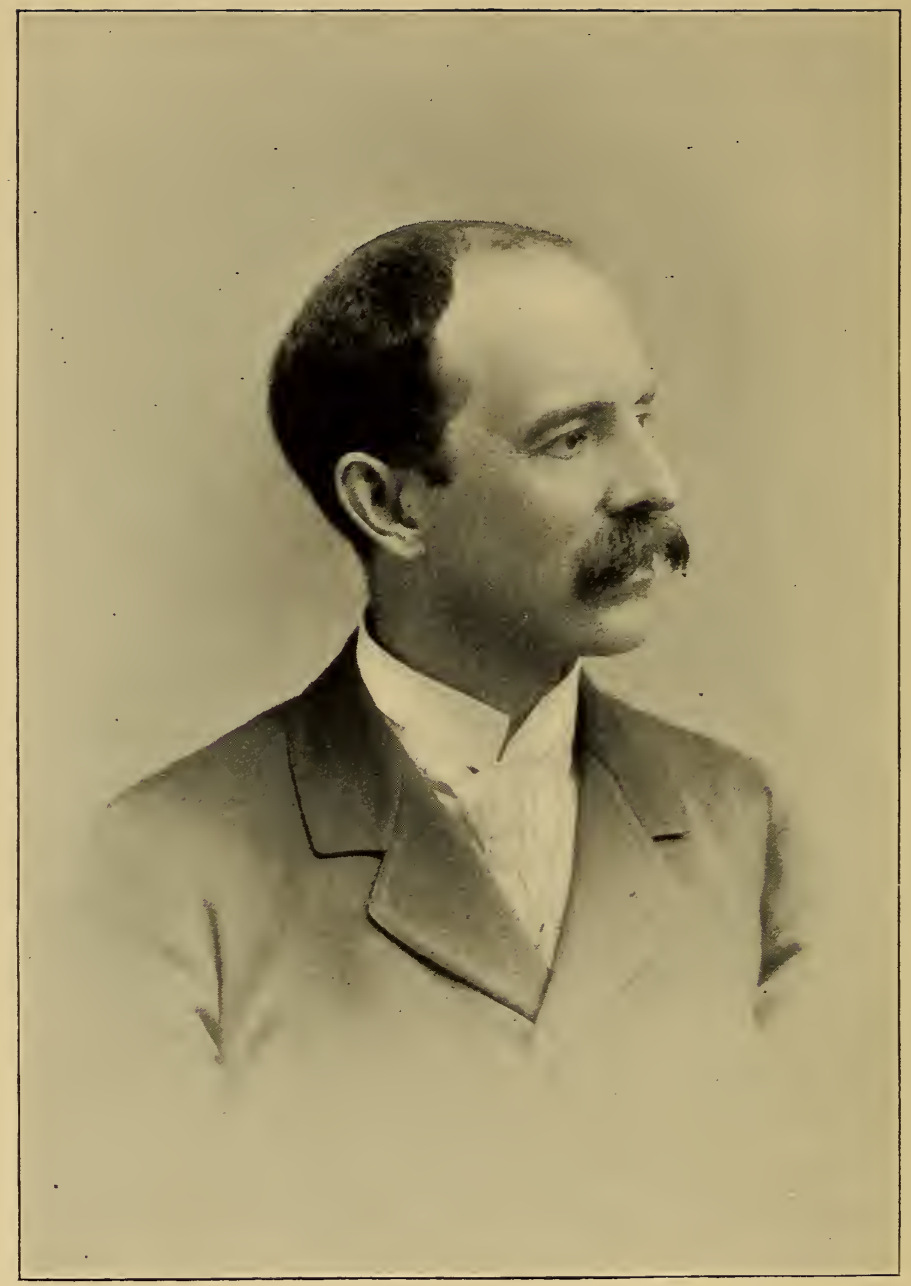

Maciur L. Prumoh 


\section{DANIEL CHESTER FRENCH}

Daniel Chester French was born in Exeter, New Hampshire, in 1850, and, in 1867, settled in Concord, where the family homestead still remains.

Mr. French's paternal grandfather, Daniel French, was Attorney General of New Hampshire and his maternal grandfather, William M. Richardson, Chief Justice of the same State. His grandmother, Sarah Flagg French, was a connection of Daniel Webster, while his great-grandmother, Dorothy Whittier, was related to the poet Whittier.

After a year of study in the Institute of Technology in Boston and a period of work on his father's farm, Mr. French found his true vocation. When eighteen years of age, coming from his room one day with a grotesque figure of a frog in clothes, carved from a turnip, his step-mother exclaimed, "Daniel, there is your career!" And from his thoughtful father came appreciative encouragement.

Young French's career then chosen was entered upon with a quiet but steady enthusiasm. From May Alcott (the Amy of "Little Women"), then a teacher of drawing in Boston, he borrowed modeling tools and made some excellent groups of dogs, birds, and other animals.

As at that time there were no schools of art in Boston, young French attended Dr. Rimmer's Artistic Anatomy Classes for some time, and when, subsequently, he visited relatives in Brooklyn, he had the privilege of working for a month in the studio of J. Q. A. Ward, the distinguished sculptor.

On April 19, 1875, his first important work, "The Minute Man," was unveiled at Concord, on which historic occasion Ralph Waldo Emerson, James Russell Lowell, and George William Curtis delivered addresses, and the artist's reputation became a national one. After a year of study at Florence, Italy, with his friend, Preston Powers, under the instruction of the American sculptor, Thomas Ball (who made the imposing statue of Washington for the Boston Public Garden), he made the beautiful ideal figure of the "Sleeping Endymion," completed in 1876, which long adorned his Concord studio.

Upon his return to this country, through the influence of his father, Henry Flagg French, then Assistant Secretary of the United States Treasury, he received commissions from the Supervising Architect's Office and for some years was largely 
occupied upon colossal ideal figures for government buildings in St. Louis, Philadelphia, and Boston

The relief of "Death and the Sculptor"-a monument to his brother sculptor, Martin Milmore - stands in Forest Hills Cemetery, Boston, completed in 1882, and has been likened to the famous Parthenon sculptures for beauty of ideal and execution.

The bronze group of "Dr. Gallaudet" was erected in 1889, at the Columbian Institution for Deaf Mutes, in Washington, D. C. In this group the instructor, Dr. Gallaudet, is seated in an arm-chair, with Alice Cogswell, his first pupil, standing closely by his side, his left arm about her. Her head is leaning upon his shoulder, and her face, with an eager, questioning glance, is regarding his own, while she is trying to reproduce with one of her hands the signs made by the right hand of her teacher. The other hand of the beautiful child clasps an open book, with raised letters. Her startled look is met by an encouraging smile on the face of her teacher, while both their faces indicate that she has caught the idea of which the sign is a symbol; the successful idealization in this work has probably done more than any other to establish his fame.

In 1879 the bust of Ralph Waldo Emerson was executed for Harvard Memorial Hall, a replica of which is in the Public Library of Concord, as also a bust of A. Bronson Alcott in the latter building. The relief of "Death and the Sculptor," for which Mr. French received a gold medal from the Paris Salon, though cast in bronze, was made in New York, and is probably the only work of art executed in the United States upon which this medal has been bestowed.

Mr. French created the monument to the architect, the late Richard M. Hunt, in which work Mr. Bruce Price was his architectural collaborator. This is placed in the wall of Central Park, New York, on Fifth Avenue, facing Eightyfirst street.

His recent work, completed in 1897, includes the statue of "History" and the heroic statue of "Herodotus" for the Congressional Library at Washington. In 1898 was finished a full length statue of Rufus Choate, for the city of Boston; also a commission for three pairs of bronze doors for the new Public Library of Boston.

In August, 1896, there was dedicated in Boston a monument from Mr. French's hand to John Boyle O'Reilly, the 
distinguished poet, journalist, orator, and patriot. This group, like the Milmore monument, marks an era in American monumental work, bringing to the front an inspiring combination of reality and symbolism typical of those commemorated.

The World's Fair at Chicago, in 1893, brought to Mr. French, as to others, the heroic opportunity, and his response was the statue of Columbus, and that of "The Republic," for the Court of Honor. This type of modern American womanhood, always individually and uniquely rendered by Mr. French, was fully realized in this majestic statue of "The Republic," which stood in the main lagoon, facing the Peristyle.

The colossal figure of Major-General George Gordan Meade in bronze is one of the outstanding attractions on the Monumental Memorial in West Fairmount Park, Philadelphia, completed in the year 1912 .

Some twenty years ago a biographer wrote "'The artistic career of Mr. French, which is allied to that of a noble group of artists in the East and in the. West, is instructive, and affords grounds for national as well as individual encouragement. It leads to the hope that our country is developing a school of art and artists which, while not too independent to learn what can be and should be learned from other nationalities, will still be originally and distinctively American." 


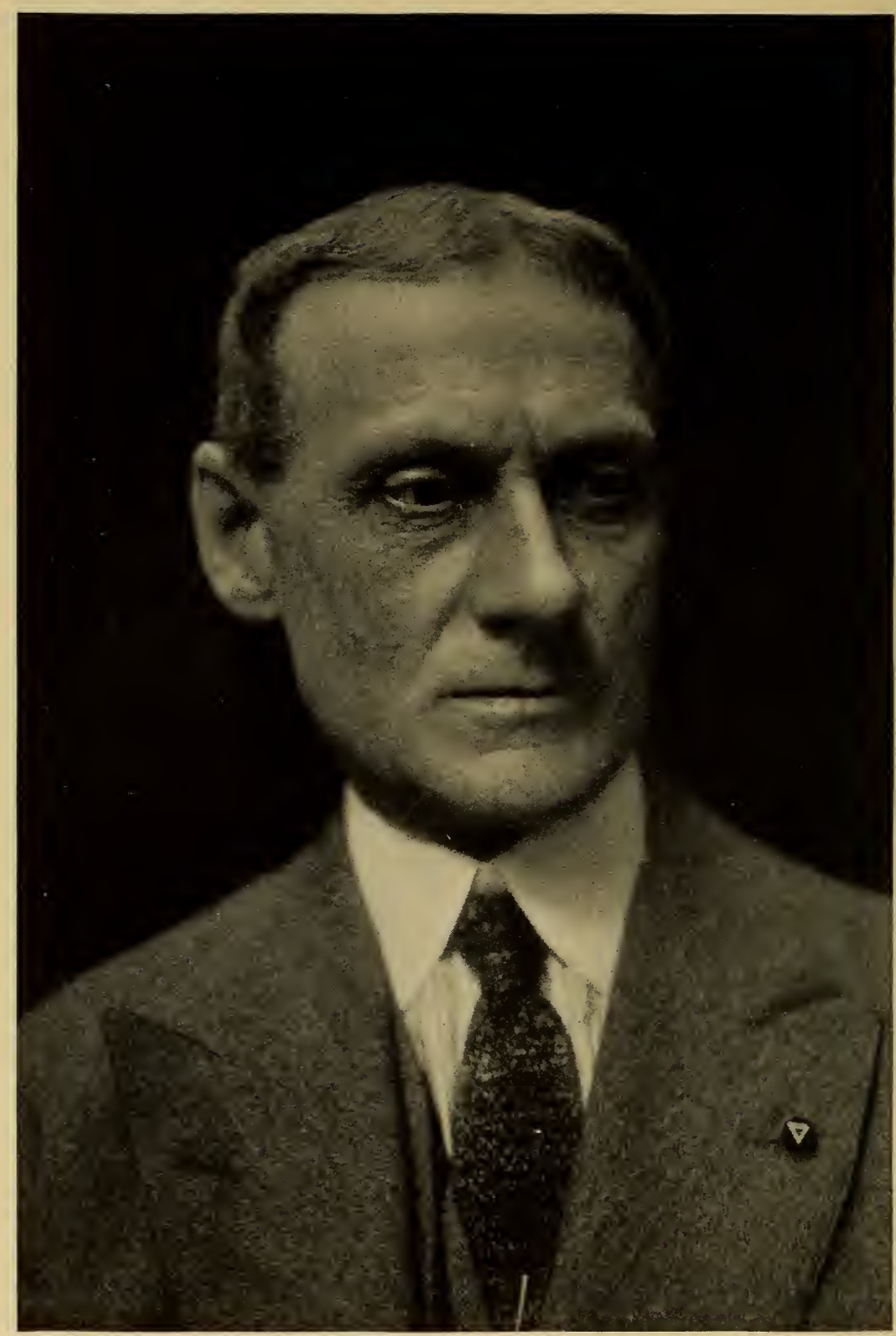

CHARLES GRAFLY-Sculptor 


\section{CHARLES GRAFLY}

Charles Grafly, sculptor, was born in Philadelphia, December 3, 1862; son of Charles and Elizabeth (Simmons) Grafly; pupil Pennsylvania Academy of the Fine Arts and Chapu and Dampt, Paris; married "Frances Sekeles, of Corinth, Miss., June 7, 1895. Honorable mention Salon of 1891; Temple Trust Fund, Philadelphia, 1892; medal Chicago Exposition, 1893; silver medal Atlanta Exposition, 1895; Converse gold medal, Pennsylvania Academy of the Fine Arts, 1899; gold medal Paris Exposition, 1900, Charleston Exposition, 1901, Buffalo Exposition, 1901; member of International Jury of Awards, St. Louis Exposition, 1904; instructor of sculpture, Pennsylvania Academy of the Fine Arts since 1892. Represented in permanent collections of Pennsylvania Academy of the Fine Arts, Detroit Art Museum, St. Louis Museum, Carnegie Institute, Pittsburgh, Boston Museum. Member Municipal Art Jury, Philadelphia; N. A., 1906; member National Institute of Arts and Letters, National Sculpture Society, Architectural League, Philadelphia Art Club. Much notable work in busts, life size and colossal figures and portraits, and ideal figures and groups, largely in bronze. George D. Widener gold medal, 1913. Member of the International Jury of Awards, Panama Exposition, 1915. Instructor in the School of Boston Museum of Fine Arts since 1917. 


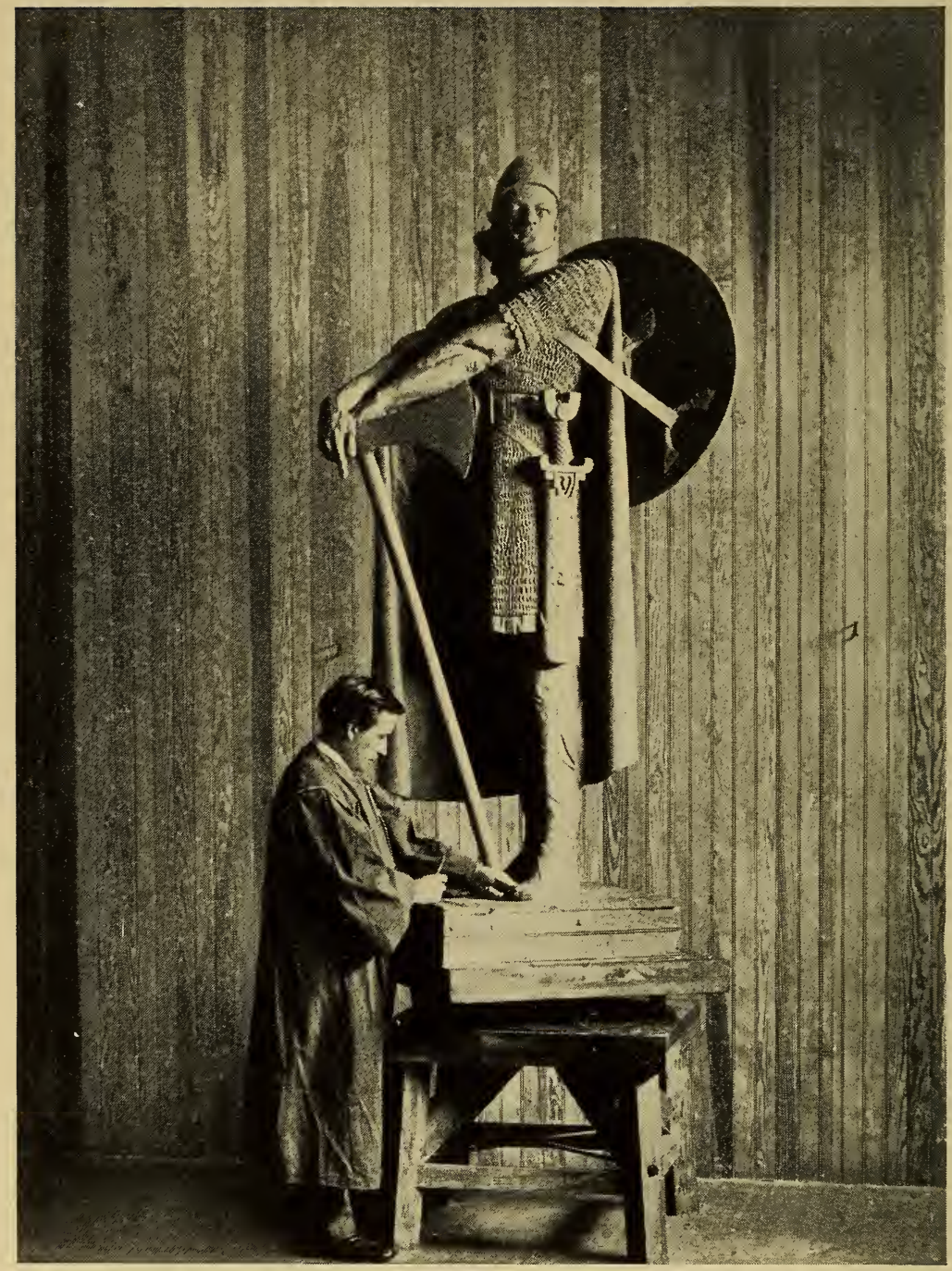

EINAR JONSSON-Sculptor 


\section{EINAR JONSSON}

Einar Jonsson was born near Reykjavik, the capital town of Iceland. His father was a peasant and Einar when a lad tended his father's flock, as in Biblical times.

But the boy's greatest pleasure was to carve figures out of wood and bone, showing the latent genius of which he was possessed.

As the lad reached maturity, he was eager to study art and his parents were finally induced (through the influence of a visitor who realized the possibilities of such a course) to send their-son to Copenhagen, where he spent two years in the Royal Academy, thence to Rome, where he acquired a thorough knowledge of anatomy and other branches of his chosen profession.

With an inclination to the antique, he soon commanded attention, receiving many commissions in his home in Iceland.

When the World War occurred, Einar Jonsson was engaged on several important commissions for continental patrons, all of which were necessarily cancelled, and it was at this moment that J. Bunford Samuel learned of this sculptor's ability and familiarity with the theme desired to be incorporated in the first of the statues to be erected in accordance with the will of his wife, Ellen Phillips Samuel, deceased. Mr. Samuel in a most generous spirit decided to present this first statue at his own expense, although the bequest of his wife would not be operative until after his own death. Einar Jonsson with his wife, whom he had recently wedded, were brought from Iceland to Philadelphia as Mr. Samuel's guests.

Here Jonsson modeled in full size and had cast in bronze his statue of Thorfinn Karlsefni, the Scandinavian explorer, who had visited the shores of America as early as 1004, landing apparently in the vicinity of Vineyard Haven on the Massachusetts coast, a most fitting beginning to the splendid scheme to follow in succeeding years. 


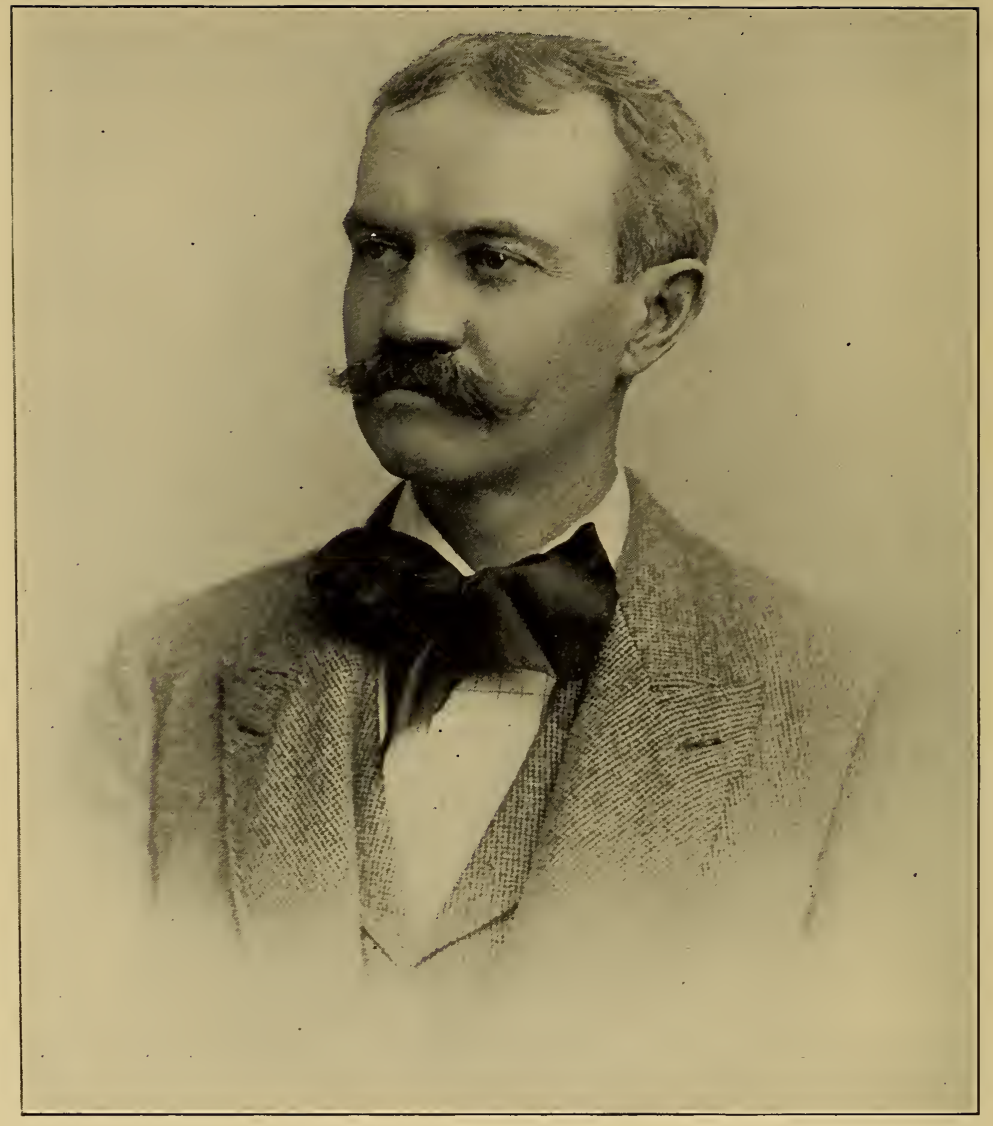

EDWARD KEMEYS-Sculptor 


\section{EDWARD KEMEYS}

Mr. Kemeys was born in Savannah, Georgia. His ancestors had resided in this country for generations and were of Welsh descent. He was educated in New York, served in the United States Army through the Civil War and was a captain of artillery at its close. Later he was attached to the engineer corps in Central Park, New York. He began the study of modeling in 1871. Within a year his group of "Hudson Bay Wolves" was discovered by the Fairmount Park Art Association and cast in bronze. In 1877 he went abroad, exhibiting his group, "Buffalo and Wolves," in the Paris Salon 1878 and in London. His "Still Hunt," in bronze, was placed in Central Park in 1883; "Buffalo Heads," New York Produce Exchange, soon after, and "Buffalo Heads," New Omaha Bridge, 1886. Mr. Kemeys modeled numerous animals for bridges over the lagoons of the Columbian Exhibition of 1893 and the famous colossal lions in front of the Chicago Art Institute, 1895; also Heads of Indians, French Governors and Coureur du Bois for the Marquette Building, Chicago. 


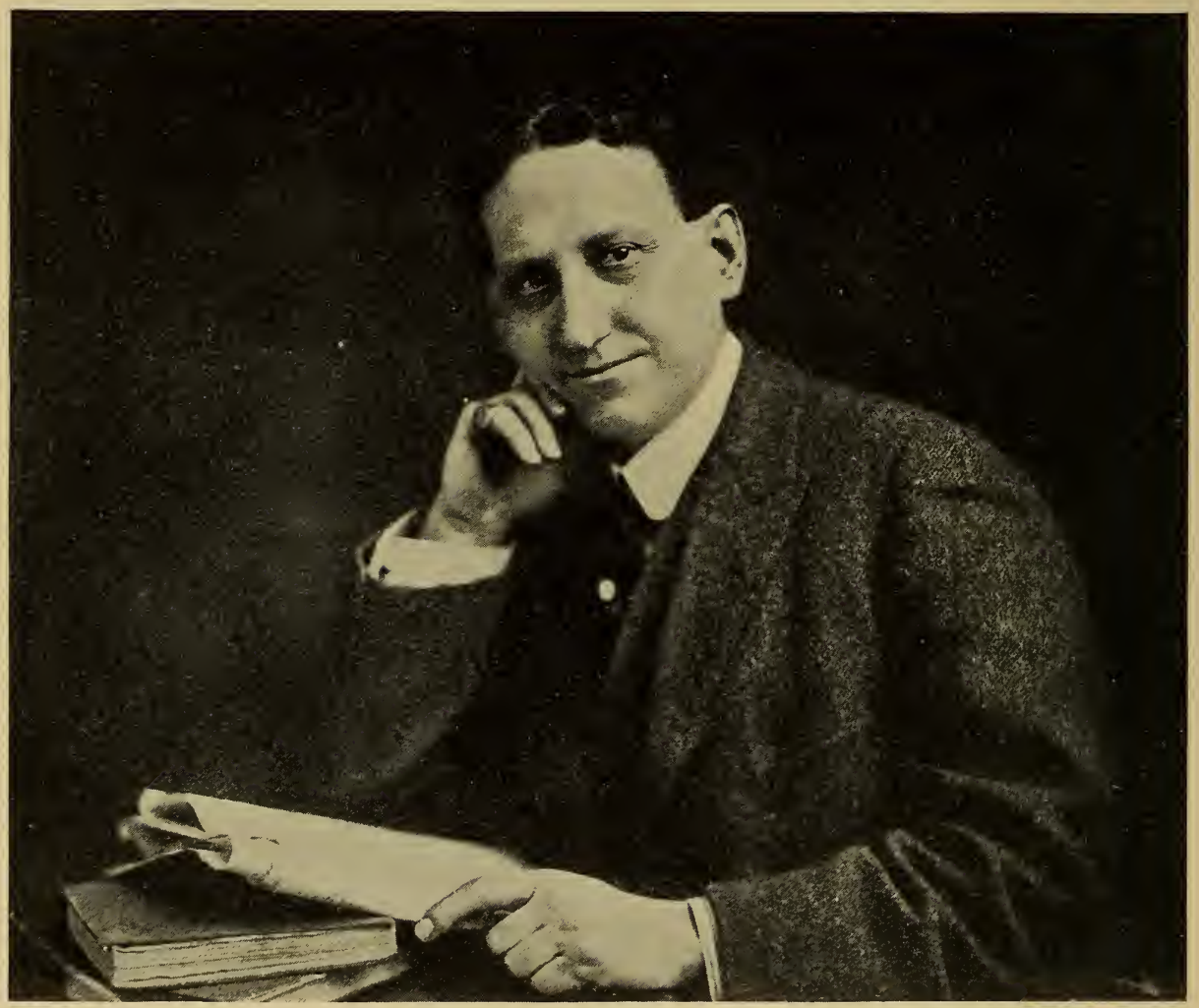

ALBERT LAESSLE-Sculptor 


\section{ALBERT LAESSLE}

Albert Laessle, sculptor, born in Philadelphia March 28, 1877, son of Henry Christian and Caroline Louise (Metzger) Laessle, graduate Spring Garden Institute, Philadelphia, 1896, Drexel Institute 1897, Pennsylvania Academy of the Fine Arts, 1901, studied with Charles Grafly, Philadelphia, and with Michel Bequine, Paris, 1904-7; married Mary Prudden Middleton, of Philadelphia, June 7, 1905. Awarded Stewardson prize 1902, Cresson traveling scholarship, 1904-7 (both Pennsylvania Academy of the Fine Arts); bronze medal Buenos Aires, 1910; gold medal, San Francisco Exposition, 1915; Fellowship prize, Pennsylvania Academy of the Fine Arts, 1915; first prize for sculpture in "Americanization through Art" Exhibition, Philadelphia, 1916; George D. Widener memorial gold medal, Pennsylvania Academy of the Fine Arts, 1918. Represented in permanent collections, Pennsylvania Academy of the Fine Arts, Philadelphia Art Club, Metropolitan Museum (New York); Carnegie Institute (Pittsburgh); Peabody Institute (Baltimore); the bronze "Billy," Rittenhouse Square, Philadelphia, 1917. Member National Sculpture Society, The New Society of Artists (New York); The Philadelphia Art Alliance; The Painters and Sculptors of Animal Life (New York); Société des Amis de la Medaille d'Art, Brussels, Belgium. 


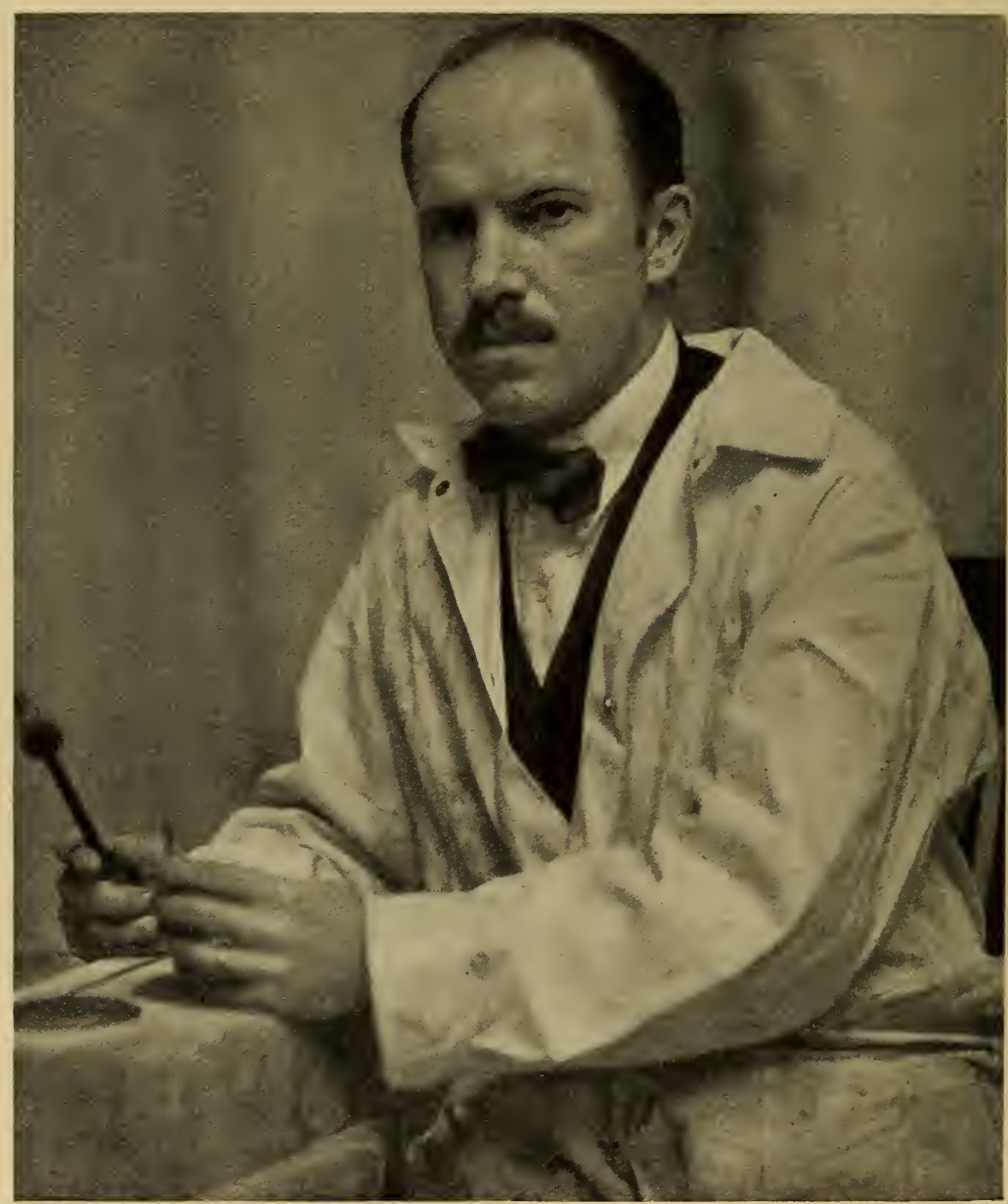

PAUL. MANSHIP-Sculptor 


\section{PAUL MANSHIP}

Paul Manship, sculptor; born, St. Paul, Minnesota, December 24, 1886; studied, St. Paul Institute of Fine Arts, Pennsylvania Academy of the Fine Arts, Philadelphia; awarded prize scholarship of American Academy in Rome, 1909-12; medals, Barnett prize, N. A. D. 1913; awards, Widener Gold medal, P. A. F. A. 1914; Panama Pacific Exhibition Gold Medal, San Francisco 1915; societies, National Academy of Design; National Inst tute of Arts and Letters; National Sculpture Society; Architectural League of New York; Century Association. Work represented in following museums, Metropolitan Museum of New York; Corcoran Art Gallery, Washington; Fairmount Park Art Association, Philadelphia; Art Institute of Chicago; City Art Museum, St. Louis; Minneapolis Institute of Art; Detroit Museum of Art; Fogg Museum of Harvard College; Smith College Museum; Cleveland Art Museum. 


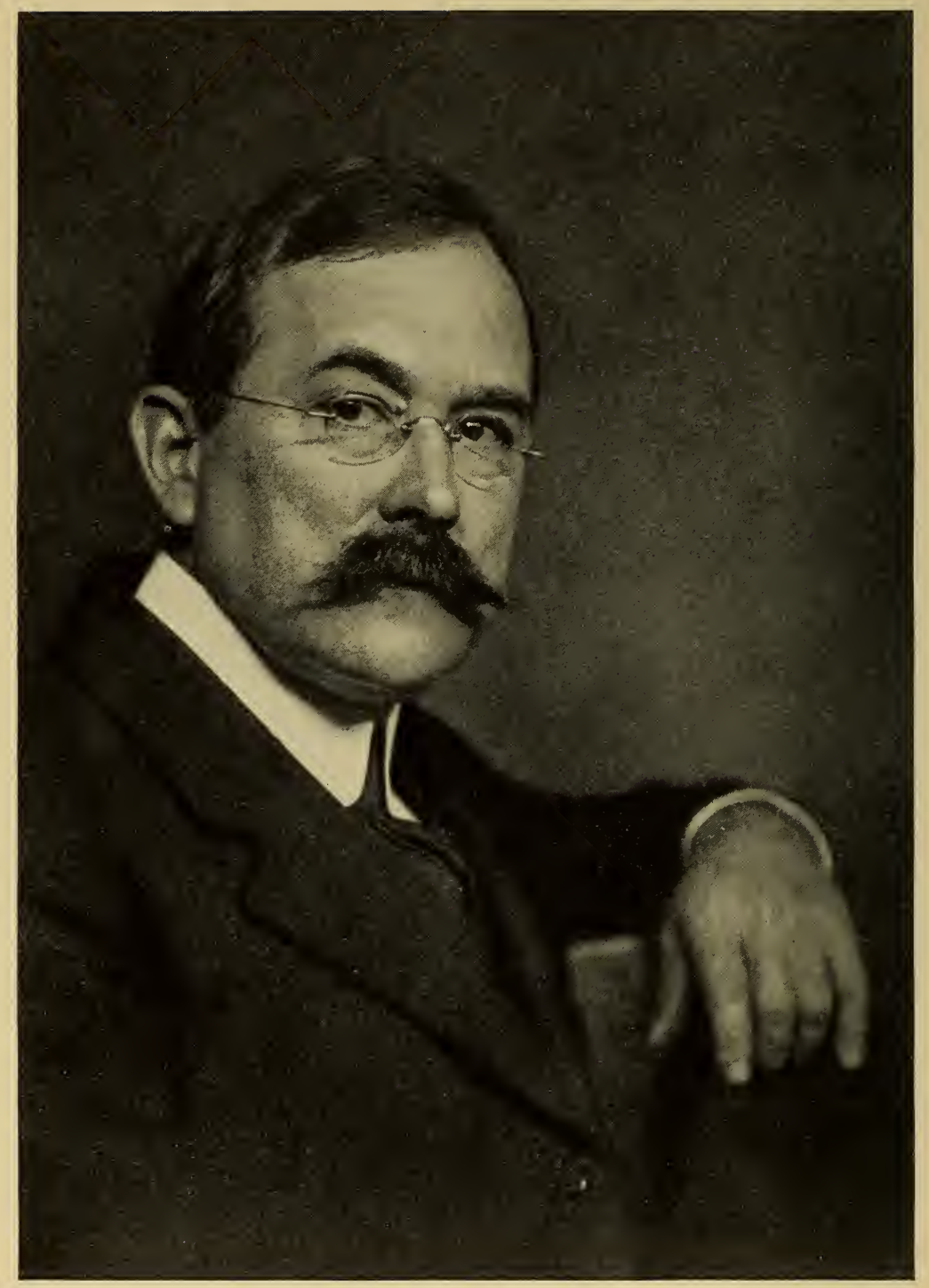

SAMUEL MURRAY 


\section{SAMUEL MURRAY}

Born in Philadelphia June, 1870. Studied under Thomas Eakins at the Art Students League, Philadelphia. Mention World's Columbian Exposition, 1893. Silver Medal St. Louis Exposition. Gold Medal Art Club, Philadelphia, 1894. Honorable Mention, 1897. Sculpture, Pennsylvania State Monument Gettysburg; Deshong Memorial Statue, Chester; Father Corby Statue, Notre Dame University, Notre Dame, Indiana; Barry Statue, Independence Square, Philadelphia; Leidy. Statue, City Hall Square, Philadelphia; Decoration of Witherspoon Building, Philadelphia, with ten colossal statues of Prophets. 


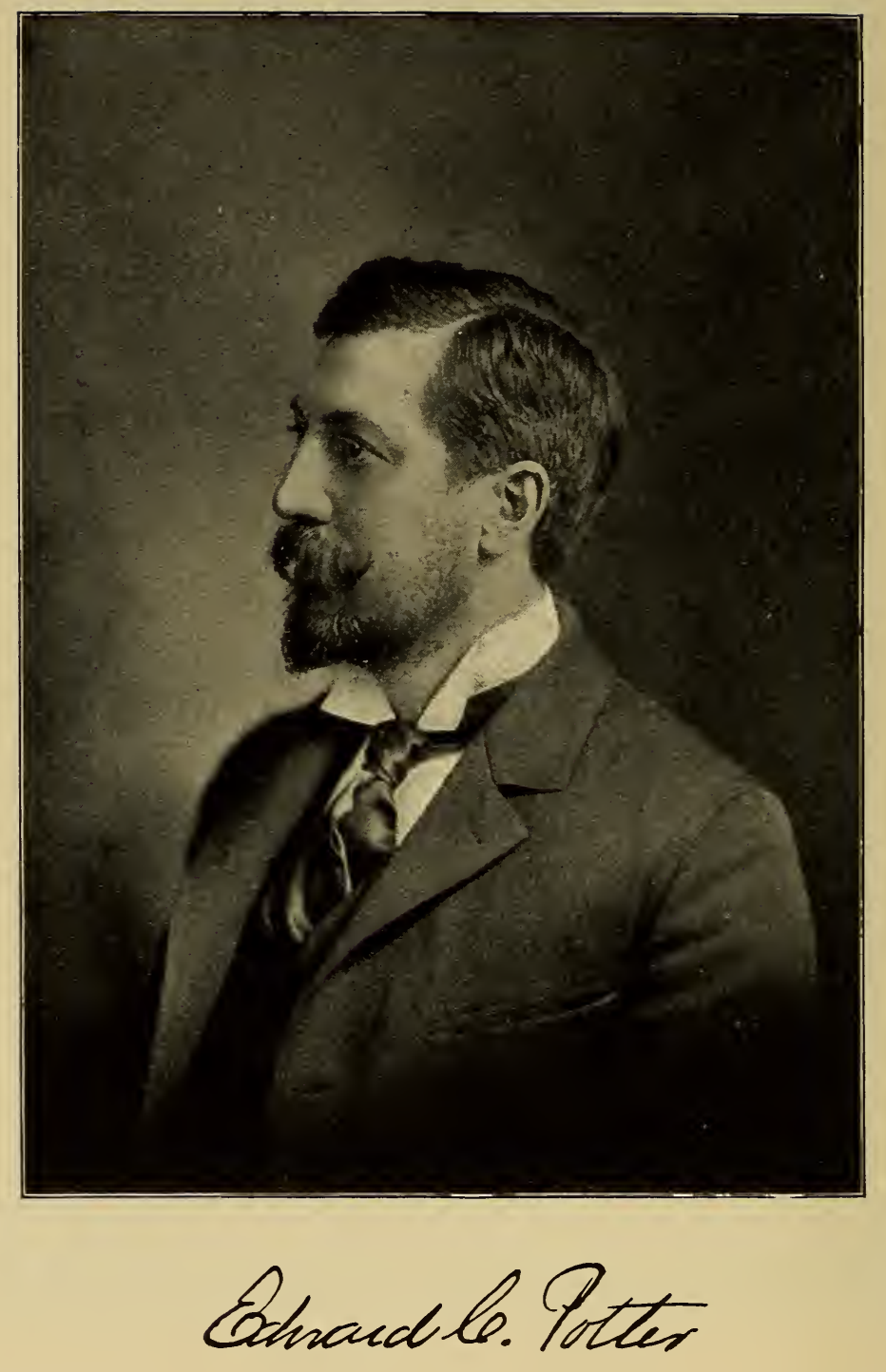




\section{EDWARD C. POTTER}

Edward C. Potter was born November 26, 1857, at New London, Connecticut.

At the age of seventeen he entered Williston Seminary, Easthampton, Massachusetts, remaining there four years, when he entered Amherst College in the class of 1882.

After his college life he began drawing at the Boston Art Museum, under Frederick Crowninshield and Otto Grundman, besides modeling with T. H. Bartlett. In 1886 he undertook sculpture seriously, studying with Daniel Chester French.

A year later Mr. Potter went to Paris and studied under Mercier and Frémiet. During his stay of two years there, he exhibited at the Salon small groups of rabbits, the bust of a negro, and a sketch from an Indian group. A sleeping infant faun, with rabbit, which was executed at Paris, was sold to the Art Institute of Chicago, where it now is.

In collaboration with Mr. French, Mr. Potter made the famous groups of horses and bulls for the Quadriga at the World's Fair, Chicago, 1893. Since that time he has made two lions, finials for the gate-posts at the entrance to $\mathrm{Mr}$. C. P. Huntington's residence, New York City; also a bust of the late Vice-President Wheeler, for the Senate Chamber, Washington; the statue of Robert Fulton, for the Congressional Library at Washington, and a portrait-statue of Austin Blair, for the State of Michigan; also the horse for the statue of George Washington for the city of Paris.

In 1894 the Fairmount Park Art Association decided to give a commission for an equestrian statue of General Ulysses S. Grant and it was awarded to Daniel C. French, who expressed a desire to have Mr. Potter model the horse and have his name appear upon the plinth. This request was acceded to by the Board of Trustees of the Association and the justice of this request has been fully realized by the result attained. 


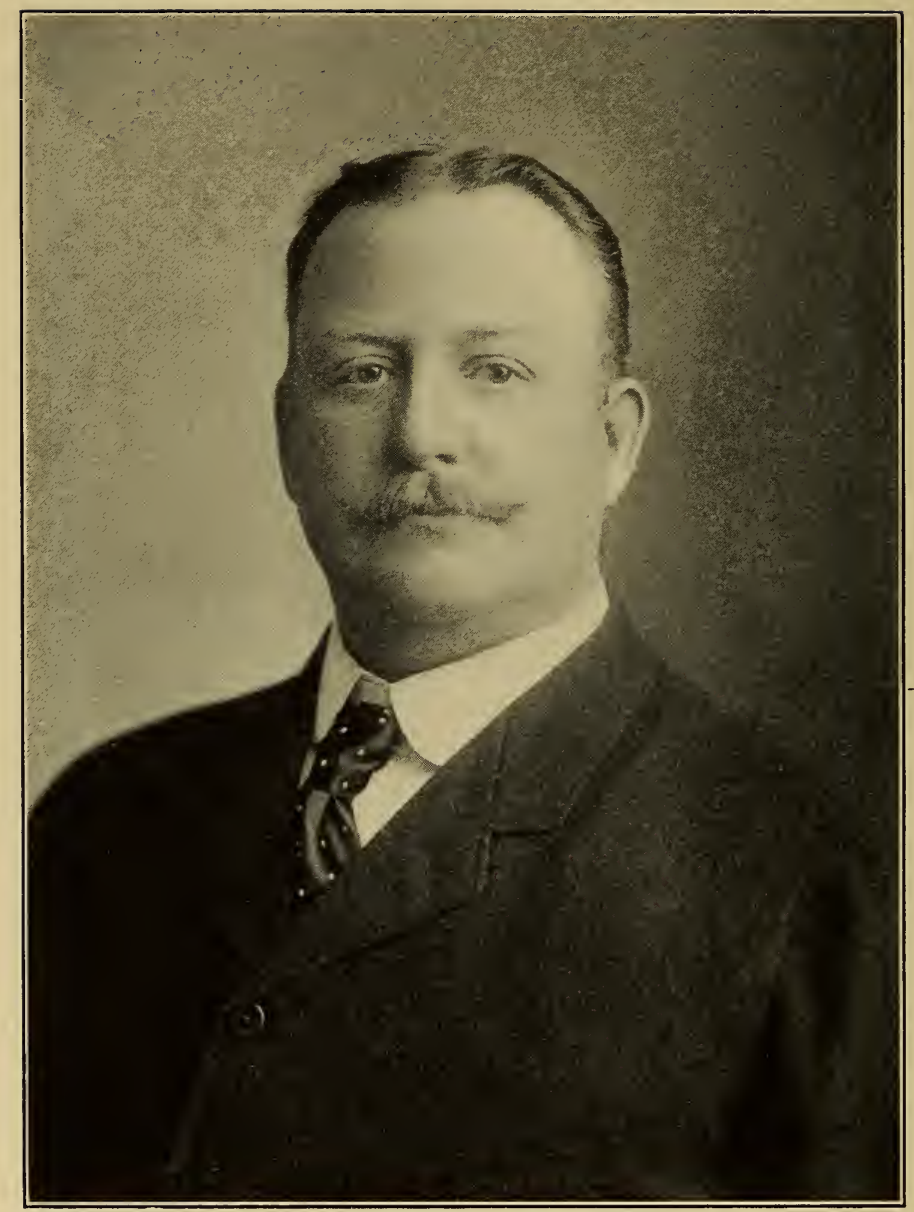

FREDERIC REMINGTON 


\section{FREDERIC REMINGTON}

Born October, 1861, in Canton, N. Y. He attended school in New England and studied art for a year in the Yale Art School, until his father, Col. S. P. Remington, died. He then gave up his studies and went to Montana in 1880 and followed varying fortunes in the various parts of the West until he burned to depict its picturesque features in paint and clay.

He began as a correspondent for Harper's Weekly in the Geronimo campaign in Arizona and gradually worked into magażine illustration, doing President Roosevelt's book on "Cow-Boy Life," which ran in the Century.

He was the first man to do horse-action as it really is, and was the subject of great controversy at the time. He was one of the first men to do "lost wax" bronze statuettes in America. "The Broncho Buster," "The Old Dragoons," "The Scalp," "The Cheyenne," "Comin' Thro' the Rye" (a group of cow-boys which was put up in staff at St. Louis and Seattle), "The Rattlesnake," "The Montana Man," and others were his work. Some of these are in the Metropolitan Museum at New York and the Corcoran Gallery at Washington. The Fairmount Park "Cow-Boy" is the only sculpture which he made in an out-of-door size, and represents a good type of the old Texas cow-boy, who came up over the trails with cattle in the early eighties on a small Spanish horse. The saddle, hat and other accoutrements are of that day and must not be confused with later things. These were the plainsmen who traveled by the stars.

As an author, Mr. Remington produced such works as "Pony Travels," "Crooked Trails," "Men with the Bark On," "Sun Down Leflare," and others, and as a painter tee made the whole field of the wild, free life of the plains and foot-hills his own.

No man of this generation, in any country or clime, has asserted with more authority the right of the artist to express himself and the emotions, with which the throbbing life of his own day inspires him, than Mr. Remington. None has owed less to the traditions of the schools or has been less overawed by academic conventions or the dictation of pretentious patronage. He has delivered his own personal message fearlessly and distinctly and has struck one of the freshest and most vital notes that has yet been heard in American art. 


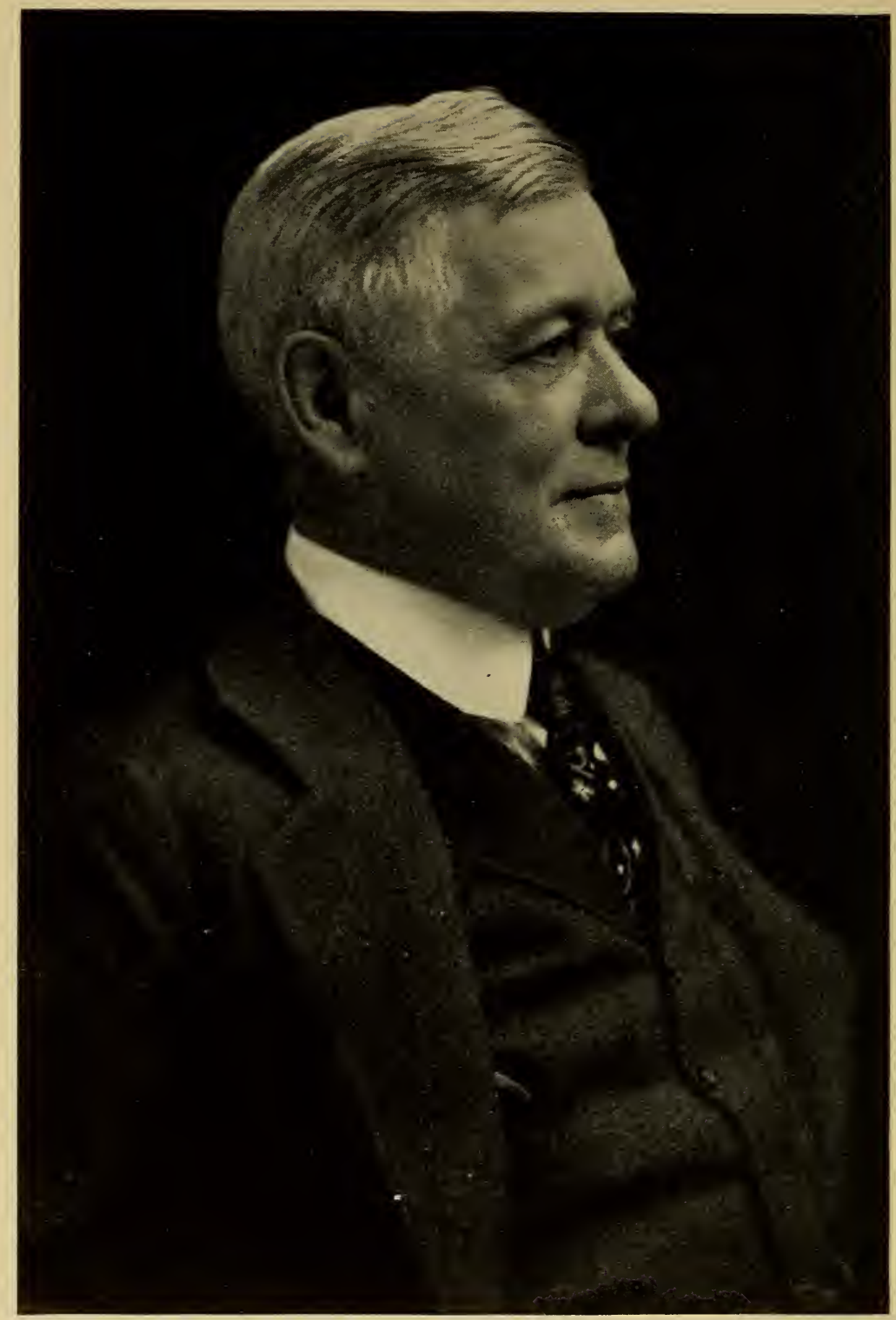

J. MASSEY RHIND-Sculptor 


\section{J. MASSEY RHIND}

J. Massey Rhind, second son of John Rhind, R.S.A., a prominent Scotch sculptor, was born in Edinburgh in 1858. After several years' apprenticeship with his father he went to London to continue his studies. He attended the Kensington Art School and received as a prize a four-year scholarship in the Royal Academy; at the conclusion of his studies there he received a traveling scholarship of some three years to study in France and Italy. He came to America in 1889. Among his principal works are the $\mathrm{H}$. H. Houston statue on the "ramble" and the heroic Indian on Wissahickon Drive, Fairmount Park; some of the decorations on the Monumental Memorial, Fairmount Park, and the statue of Stephen Girard, City Hall - all the above in Philadelphia - the fountain at Georgian Court, George Gould's residence at Lakewood, N. J.; the decorations on the Carnegie Institute, Pittsburgh; the tympana on the Agricultural Building, Washington; the allegorical decorations on Gen. Grant's Tomb, New York; the equestrian statue of George Washington at Newark, N. J.; the decorations on the Memphis and Indianapolis Courthouses; the figures of "Minerva" and "Apollo" on the Butler Art Institute, Youngstown, Ohio; and the recently completed heroic marble statue of the late President McKinley, for the McKinley National Birthplace Memorial at Niles, Ohio, for which he also executed portrait busts of members of McKinley's cabinets.

Mr. Rhind received a gold medal at the St. Louis Fair and a silver one at the Buffalo Exposition. 


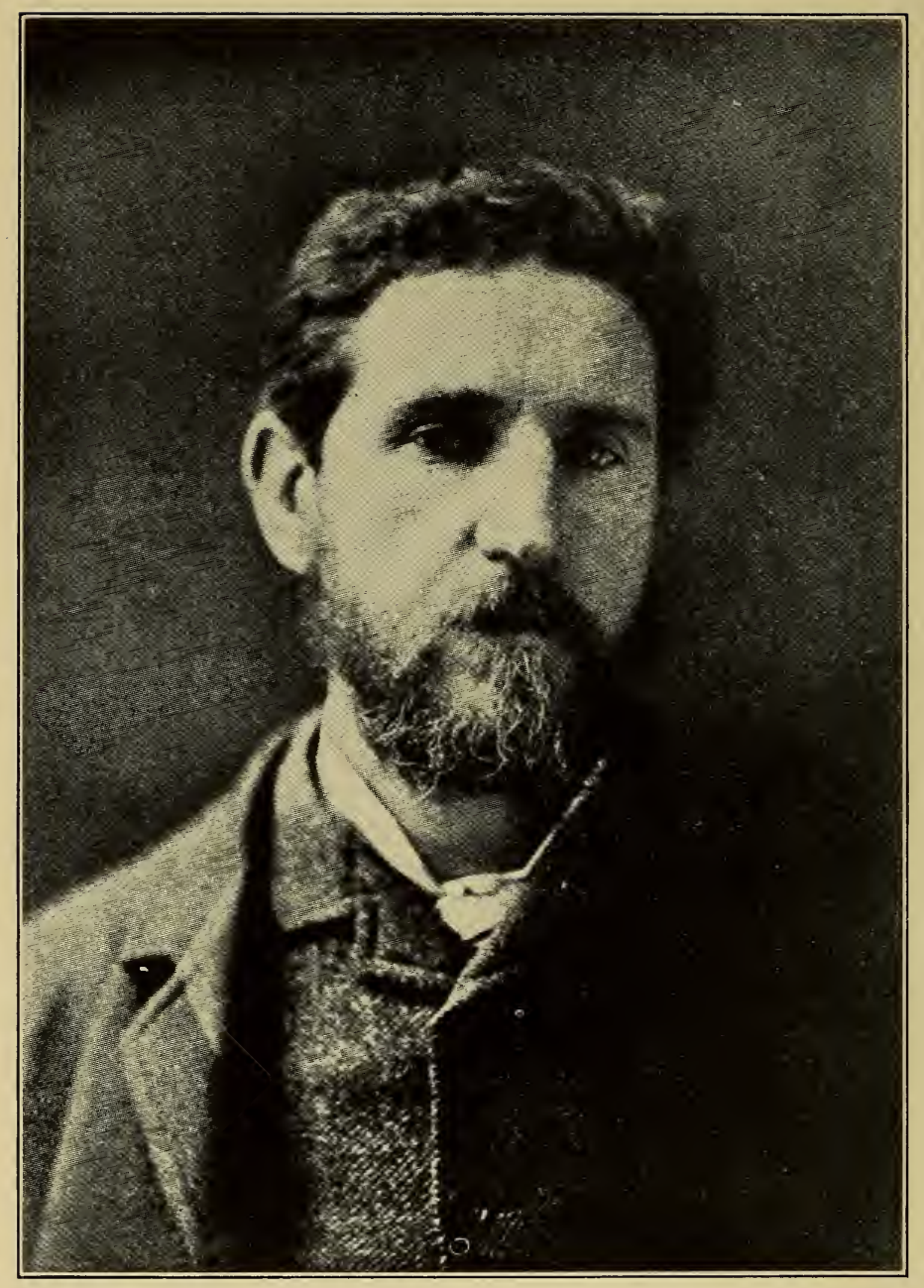

Amaritur Stlfanclens 


\section{AUGUSTUS SAINT GAUDENS}

Augustus Saint Gaudens was born in Dublin, Ireland, March 1, 1848, and was brought to the city of New York at the age of six months. His father was a Frenchman from the south of France, his mother being a native of Dublin, Ireland. Augustus attended public school in New York until he was thirteen years of age, at which time, evidencing a taste for artistic work, he was apprenticed to a stone cameo cutter, in which position he remained until his nineteenth year, in the meanwhile studying at the Cooper Institute and at the Academy of Design during the evening after business hours. In 1867, visiting Paris, he entered at the Beaux Arts, remaining under Jouffroy until the Franco-Prussian War, supporting himself in the meanwhile by the cutting of cameos. In 1870, visiting Rome, he remained there for three years, modeling "Hiawatha," subsequently purchased by Governor Morgan.

The first important work he produced was the Admiral Farragut, placed in Madison Square, New York, which for originality of conception and boldness of design, as well as artistic merit, takes the front rank among the artistic productions of the world.

Among the most important works by St. Gaudens are the following: Reredos for St. Thomas' Church, New York; tomb for Mrs. Le Roy King in Newport, both in conjunction with Mr. La Farge; caryatides and portraits for the residence of Cornelius Vanderbilt, New York, and reliefs for the same building; statue of Robert Randall for the Sailors' Snug Harbor; Abraham Lincoln, at Chicago; Angel with tablet, at Newport, for Mr. Smith; Puritan, at Springfield, for Chester W. Chapin; monument for Mr. Hamilton Fish, at Garrisons-on-the-Hudson; monument over the grave of Mrs. Henry Adams, in Washington; a number of medallions and portrait memorials for churches and libraries; monument of Peter Cooper; equestrian monument in high relief to Colonel Robert Gould Shaw for Boston; equestrian statue of General Logan for Chicago; equestrian statue of General Sherman for New York; and monument to Phillips Brooks in Boston, and groups for the entrance to the Public Library of that city.

The commission for the Garfield monument was given to Mr. St. Gaudens by the Board of Trustees of the Fairmount 
Park Art Association, and after mature consideration the design adopted was that of a portrait bust in bronze with an allegorical figure supported by marble columns on a granite base. In conference with his architect, Mr. Stanford White, a site on the East River Drive below Girard Avenue bridge, nearly opposite to the Rond Point fountains, was selected. This was granted by the Commissioners of Fairmount Park and has been embellished with landscape gardening by the Commissioners, which has added greatly to the value of the location.

Between the pilasters of granite is the figure of a woman in bronze, of heroic size - typical of America-holding in her hand the sword and palm, symbolical of Garfield's life, and bearing his name on the sh:eld which she holds in front of her. Surmounting four square granite pilasters is the bust of Garfield in bronze, of heroic size.

\section{JAMES THOM}

James Thom was born in Ayrshire, Scotland, in 1799. In his youth he was a stone mason but having taught himself sculpture he produced sandstone statues of "Tam O'Shanter" and others which obtained great popularity. He came to America in 1836 and died at New York in 1850. 


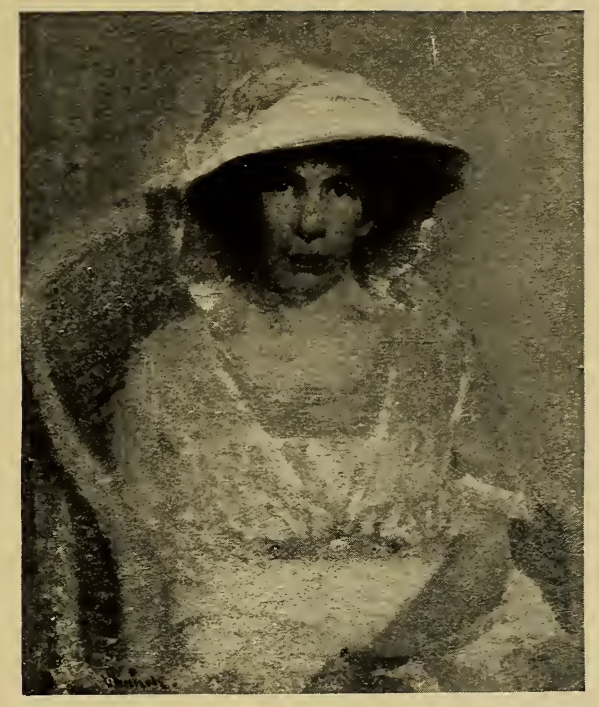

MRS. BESSIE POTTER VONNOH Scu!ptress

PORTRAIT: BY ROBERT W. VONNOH

\section{BESSIE POTTER VONNOH}

Bessie Potter Vonnoh, sculptress, was born in St. Louis, August 17,1872; pupil Art Institute of Chicago; married Robert William Vonnoh, the distinguished portrait painter, September 17, 1899. Bronze medal, Paris Exposition 1900; gold medal, St. Louis Exposition, 1904. Represented in Metropolitan Museum of Art, Art Institute (Chicago), Corcoran Art Gallery (Washington), Brooklyn Museum; A. N. A., Bronze bust Major General S. W. Crawford, Monumental Memorial, Fairmount Park, Philadelphia. 


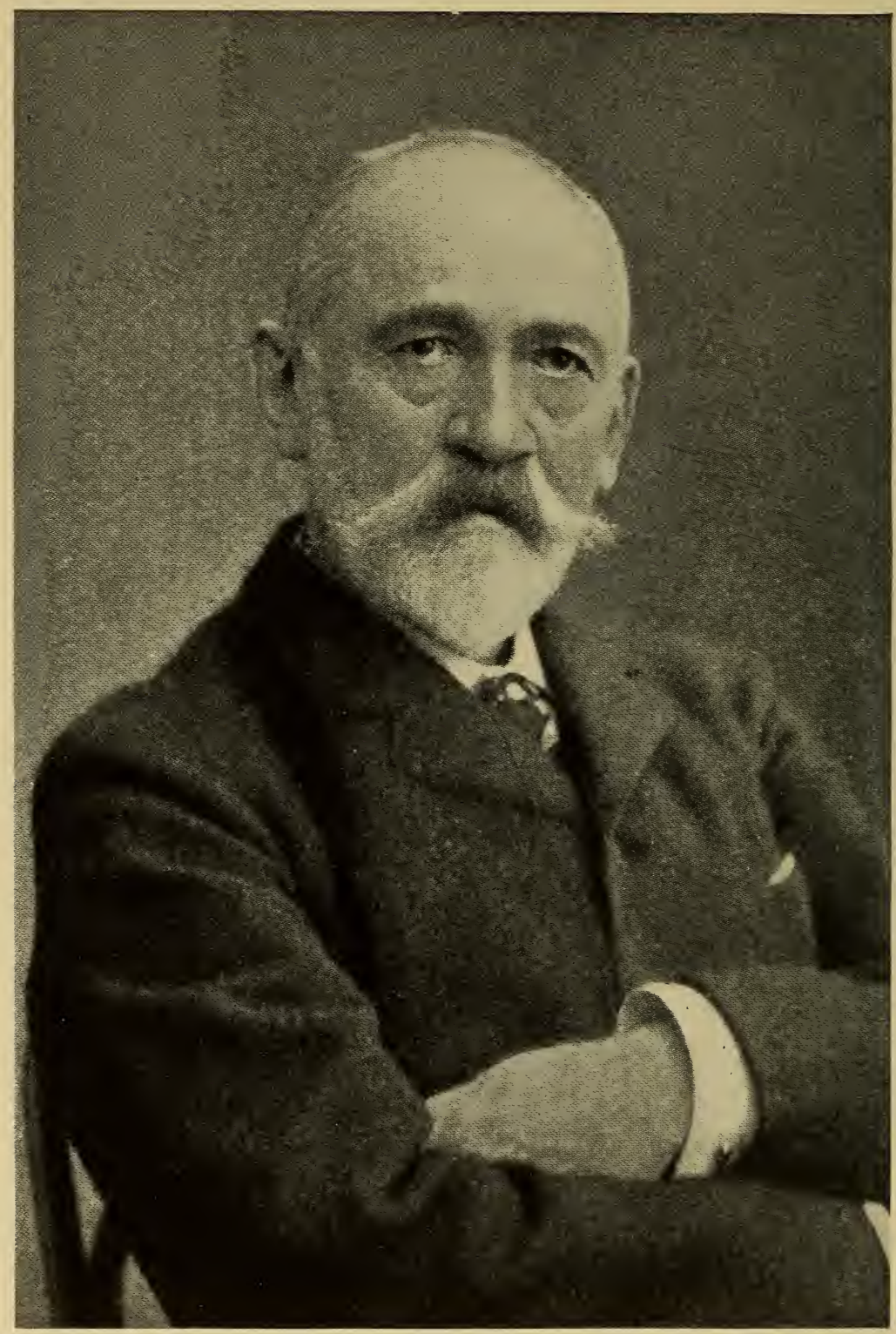

JOHN Q. A. WARD-Sculptor 


\section{J. Q. A. WARD}

The following extract has been taken by permission from "An Appreciation," written for the National Sculpture Society by Adeline Adams, and the portrait of Mr. Ward is from the same source, courtesies which are fully appreciated.

John Quincy Adams Ward was born in 1830, in Urbana, the county-seat of Champaign County, Ohio. His forbears were people of note and of hardy English stock In 1632 John Ward, of Norfolk, England, landed at Jamestown, Virginia, and established a plantation and subsequently, attracted by the favorable conditions of the Northwest Territory, he became the owner of large tracts of land in what is now the state of Ohio.

American sculpture in Ward's early days was unformed and it was not until the Centennial Exhibition of 1876 in Philadelphia, that the American with artistic inclination realized the possibilities of its development.

Ward was fortunate in gaining a position in the studio of Henry Kirke Brown in the city of Brooklyn, where he began as a paying pupil, continued as a paid assistant, and emerged as a young sculptor well fitted to win his own way.

In 1861 he opened a studio in New York, his time for several years being given to portrait busts, ornamental modeling and especially his "Indian Hunter," a notable work that brought him immediate recognition. In 1863 he became a member of the National Academy of Design and his fame grew apace. As President of the Sculpture Society he was associated with Saint-Gaudens and Warner in giving advice as to the sculptural decorations for the Congressional Library in Washington. The work is of a very high order and its completion gave a new and marvelous impetus both to our vainting and to our sculpture. To-day the achievement of Ward speaks for itself; his life work has shown that he was of those who "follow the arts from nobleness of mind." 


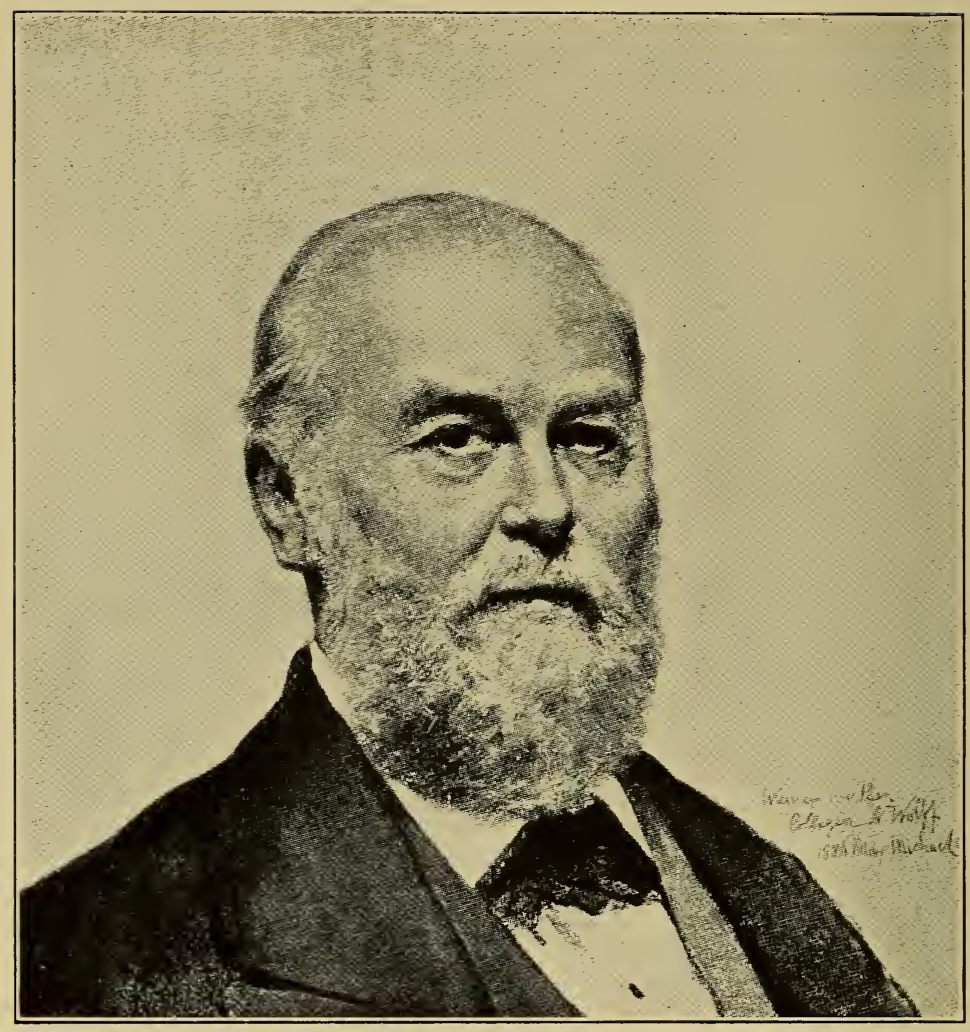

ALBERT WILLIAM WOLFF 


\section{ALBERT WILLIAM WOLFF}

Albert William Wolff represented in German sculpture the ebb of classical impulse, which Christian Rauch received from Canova and Thorwaldsen and imparted to all the products of the German school in the first half of the present century. Born November 11, 1814, at Neustrelitz, Mecklenburg, three years after his greater master had ended his long struggle for recognition and assured his position by his recumbent statue of Queen Louise, he was more fortunate in his early career and was only seventeen when he entered Rauch's studio. - In 1844 he went to Carrara to superintend the production in marble of his own works and those of his master, designing at this time the marble figures on the Orangery at Potsdam, whose production he shared with E. Mayer. On his return he was elected, in 1849, a member of the Berlin Academy and in 1866 he reached the additional honor of a professorship, which he held until his death, June 20, 1892. His last work, "Dionysos and Eros," being modeled four years before his death.

Long-lived, like most German artists, his productive period extended over nearly half a century and it spanned the appearance of the modern school of sculpture, destined to make this century memorable. His work ran in these channels: multifarious portraits, for the most part of royalty, classical subjects in the style originated by Canova and Thorwaldsen, and animal groups. To the public eye his most conspicuous work was the "Lion Tamer," which stands on the left of the great staircase of the Old Museum in Berlin, having on the opposite side Kiss' statue of an amazon on horseback attacked by a leopard. A replica of Wolff's work has been cast in bronze, in Philadelphia, from the original plaster cast, which was purchased in Berlin by the Fairmount Park Art Association. 



\section{THE \\ FAIRMOUNT PARKWAY}




\section{An outline of the}

\section{HISTORY OF THE FAIRMOUNT PARKWAY}

by

Andrew Wright Crawford, George S. Webster

and the late William Perrine

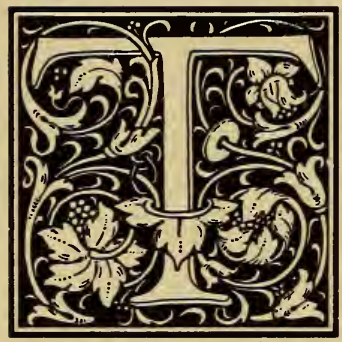

HE proposal for an adequate route from the heart of the city of Philadelphia to Fairmount Park was almost, if not actually, contemporaneous with the acquisition of the park. In 1871, the year of the founding of this Association, there appeared from the press of John Pennington and Son an unsigned pamphlet, entitled "Broad Street, Penn Square and the Park." It contained a proposal for two approaches, one to the East Park and one to the West Park. A well-drawn plan accompanied this suggestion. Callowhill Street was to be the approach to the West Park, via the "Wire Bridge," now the Spring Garden Street Bridge. The approach to the East Park was to be by a street, one block to the north of Callowhill Street, now called Willow Street, but then called Pennsylvania Avenue. When this avenue reached Twenty-first Street, it turned northwestward, as Pennsylvania Avenue does now, and the "Main Entrance" was to be where the Cincinnati Monument to Washington now is. On the west side of Broad Street, between Pennsylvania Avenue and Callowhill Street, an open space was to be created with a fountain in the centre, Broad Street being widened on the western side to obtain room for it, and the corners of the block being rounded in to two streets leading respectively to the east and west sides of the park.

The pamphlet said:

"It will be seen by looking at a map of the city that, if a straight line be drawn from the north side of Penn Square to a point a few yards to the eastward of the Girard Avenue Bridge, about one half of this line lies in the track of the Pennsylvania Avenue or Willow Street branch of the Reading Railroad." 
The author urged:

"Already we have great avenues leading to the north and to the west and to the Elysian Fields beyond Fairmount. Are they forever to be mere highways for the exclusive use of mule teams and freight cars? Or are they to be planted with trees and woods and made as attractive as those of Paris? * * * If we desire to make of our city a great metropolis, to be visited and admired by strangers, a pride and a joy to ourselves, railroads and coal-cars must not always occupy the middle and both ends of the town. * * If the great park, with which we have undertaken to adorn the city, is to be a place of general resort and to benefit all of our citizens, it must be brought within reach of all. It must be connected with Broad Street and with the centre of the city by as short a route as possible; and the avenues which lead to it must be made elegant and attractive, in short, must be made part of the park."

We are indebted to Mr. John Ashhurst, Librarian of the Free Library of Philadelphia, for calling our attention to this interesting brochure, which, so far as we know, has the distinction of being the first proposal for connecting the heart of the city with the park. The late William Perrine, the famous "Penn" of the Evening Bulletin, who collaborated in this sketch, regarded the plan just referred to as having been prepared by John Pennington himself.

The Centennial Exhibition of 1876 caused a new pride to be taken by the city in its big park and the new interest thus developed was a starting point for the Parkway promoters, among whom was Morton McMichael, then Mayor and President of the Fairmount Park Commission.

In $1884 \mathrm{Mr}$. Charles K. Landis, the founder of Vineland, N. J., presented another plan for the Parkway and we are indebted to his sister for the opportunity to reproduce it. It will be noted that its axis is almost precisely the axis of the present Parkway. The roadway was to be 150 feet wide with the tower of the City Hall as the terminus at the southeast end and a point some thirty or forty feet southwestward of its present northwest terminus at Fairmount was to be the other end of the axis. Mr. Landis also proposed, it will be observed, that the Washington monument should be placed on the axis of the Parkway, near its northwest end, a proposal which is duplicated in the plan now in course of execution. Under the map Mr. Landis wrote:

"A convenient approach to the park is a necessity. Why not make it something worthy of the magnificent city of Philadelphia?

"The best approach-the nearest from the centre-the most con- 
venient to the largest population and in the end the most economical, can be made by cutting an avenue from the angle of the square, facing the Public Buildings, and running in a straight line to the corner of Fairmount avenue and Biddle street, opposite Fairmount Park. This would afford a view of the Public Buildings at one end and Fairmount Park at the other. It would only be one mile long and strike the heart of the city. It would bring the park within easy walking distance. The avenue should be at least 150 feet wide. Buildings should be required to be set back at least 25 feet from the curb, which should be the sidewalk. There would be room for carriage ways and equestrian ways. It would cut the blocks diagonally, which affords a grand opportunity for architectural effects and for the erection of monuments, statuary and fountains. It will interfere with no important buildings.

"This proposal was first published by me April 29th, 1884, and may strike the mind as extravagant, but a little reflection will convince one that, on the contrary, it is economical-we must reflect that in a very few years this city which now has $1,000,000$ of people will have $1,500,000$ or $2,000,000$. The increased value of property upon the avenue and vicinity would amount to more than the whole expense. This has been the experience in Paris and other cities."

Either before or after Mr. Landis's plan was presented, George Rogers, an editorial assistant to Mr. McMichael (son of the former Mayor) on the North American, took up the cause of the Parkway. Rogers aroused Mr. McMichael's interest in Landis's plan and advocated it openly, when the Society of the Cincinnati came forward with the proposal to erect the Washington Monument in Independence Square.

Shortly after Mayor Stuart's entrance into office, Mr. McMichael took up the project with the Mayor and persuaded him to include a recommendation in his message to Councils that the Parkway should be considered by that body. The Pennsylvania Railroad Company and the Inquirer gave hearty support to the plan, while it was opposed by other newspapers.

About the beginning of June, 1891, a meeting of prominent citizens was held, the project was endorsed and a petition was prepared and was signed by about five hundred influential and respected citizens, who were said to represent upwards of two-thirds of the taxable property in the city. The petition urged the advisability of providing a parkway. It called for "a suitable and handsome avenue," one hundred and twenty-five feet wide, in direct line to the park, and it was presented in Common Council, on June 11, 1891, by Mr. Thomas L. Hicks of the 34th Ward.

The petition was referred to the Committee on Surveys, sent to the Board of Surveyors and reported back in Sep- 



\section{Map of the Grand Avenue to the Park, Philadelphia.}

PLEASE HANG THIS UP. FROM THE PUBLIC BUILDINGS TO THE PARK, AS PROPOSEd BY C. K. LANDIS, SEA ISLE CITY, N. J.

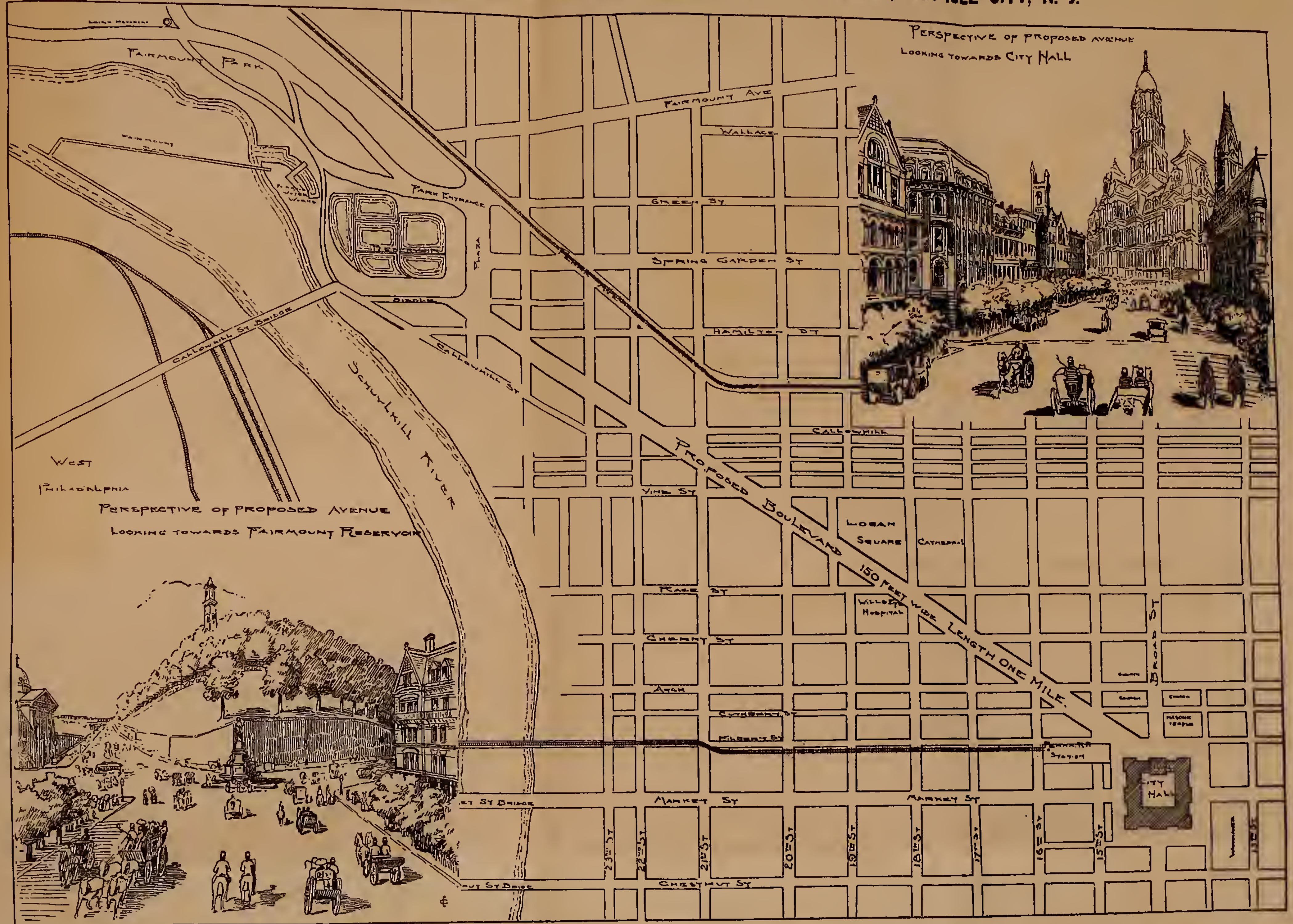

A CONVENIENT APPROACH TO THE PARK IS A NECESSITY. WHY NOT MAKE IT SOMETHING WORTHY OF THE MAGNIFICENT CITY OF PHILADELPHIA.

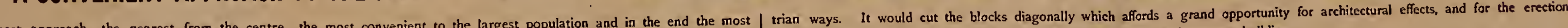
The best approach-the nearest from the centre-the most convenient to the largest population and in the end the most economical can be made by cutting an Biddle strect opposite Fairmount Park. This would afford a view of the Public Buildings at one end and Fairmount Park at the other. It would only be one mile long, and strike the heart of the city. It

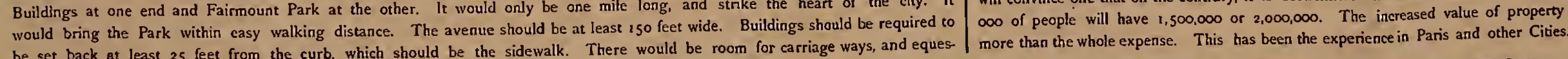
be set back at least 25 feet from the curb, which should be the sidevalk. There would be rom tor carrage ways, nnd eques 
VA GWA7R

उНT эอ คд

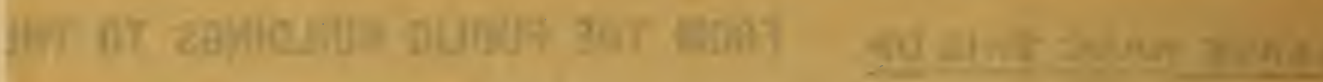

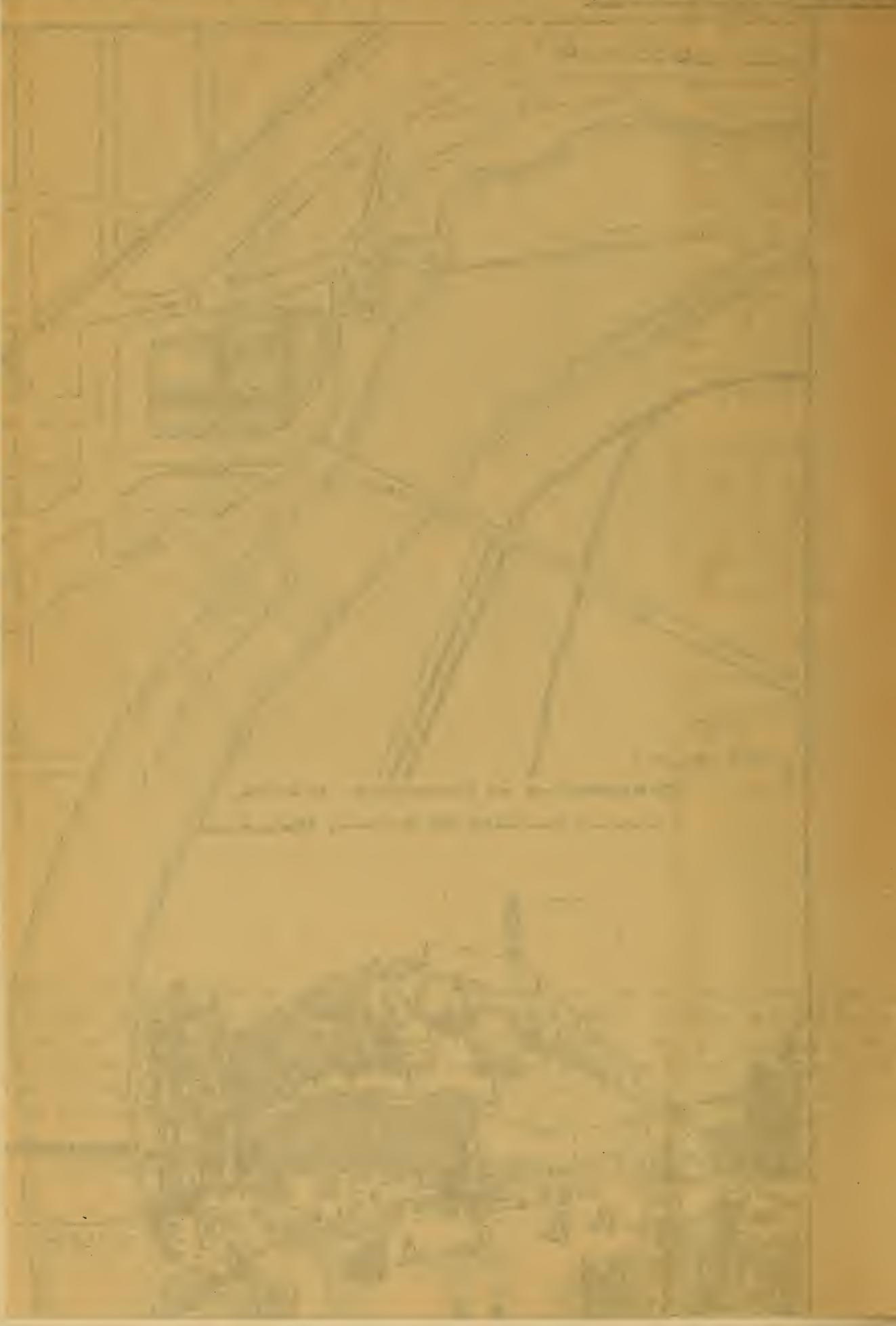


tember, 1891, with a favorable recommendation, the Survey Committee reporting to Councils on October 1st.

The ordinance was called up for consideration by $\mathrm{Mr}$. Hicks on October 8 th and put on the calender for the $22 \mathrm{nd}$. On that date it was considered. The Board of Trade urged its passage. Mr. Smithers of the 29th Ward presented a resolution of the Single Tax Society, urging that the cost be assessed on the neighboring property. Thomas Meehan, of the 22nd Ward, objected to the avenue being placed on the city plan on the ground that it might delay the improvement of that section of the city.

Consideration of the ordinance was postponed, but, on Mr. Hicks's motion, a resolution was passed, requesting the Department of Public Works to prepare plans and specifications and estimates of the cost of opening an avenue one hundred and fifty feet wide, more or less. On February 25, 1892, the Mayor transmitted the report of Director James H. Windrim, recommending that the width of the avenue be made one hundred and sixty feet and presenting three separate plans and estimates. Plan No. 3, the one approved by the Select and Common Councils, provided for a direct route.

The report was sent to the Survey Committee and the ordinance was reported back with a favorable recommendation on March 3, 1892. On the 17th of March, 1892, the bill came up for consideration on second reading. Two motions were made, one to postpone and the other indefinitely to postpone, and were voted down. On motion the bill was then referred to the Finance Committee. On March 24th that Committee reported back the bill, when C. L. Brown asked for the approval of Plan No. 1. The bill then went over until the 29th, when, after another attempt to secure an indefinite postponement, it was passed by Common Council by 71 to 27 . The next day Select Council passed it, 23 yeas and no nays.

On April 12, 1892, Mayor Stuart approved the bill. On May 1, 1893, the Board of Surveyors confirmed the plan.

On April 5, 1894, Hon. C. L. Brown introduced an ordinance to open the Park Boulevard from Nineteenth street to the north side of Biddle street. This was referred to the Highway Committee.

On April 19, 1894, Mr. Seger introduced a bill to strike the Boulevard off the City Plan. This was referred to the Survey Committee, sent to the Board of Surveyors and 
reported with a negative recommendation and on June 1, 1894, the Survey Committee asked to be discharged from its further consideration, Mr. Seger presenting a minority report.

The ordinance to open the Boulevard was taken up by the Committee on Highways and, on motion of Edward W. Patton, was referred to the Committee of the Second and Third Districts. That sub-committee reported it back with a favorable recommendation. In the general Committee the bill was amended to provide for the opening of the avenue for its full length and was reported on June 7, 1894, with a favorable recommendation.

On June 14th the opening ordinance came up in Common Council. Mr. Meehan, of the 22 nd Ward, wanted to postpone action upon it. Mr. Walton, of the 27th Ward, added an amendment providing that no railroad should ever be constructed thereon without the consent of the citizens. Mr. Hawkes, of the 20th Ward, wanted to postpone indefinitely and the debate lasted until the hour of adjournment. At the next meeting of Common Council, on June 19th, debate was resumed and again lasted until the hour of adjournment. On June 21st, the bill was again taken up and, after four hours' discussion, was passed by a vote of 84 to 27 . On June 22nd Select Council considered it and, after three hours' debate, passed it by a vote of 20 to 13 . But, to the surprise of the citizens, it was vetoed by the Mayor.

For a time the Parkway project was defeated. During Mayor Warwick's administration a move was made to secure for public use the block of ground bounded by Broad, Fifteenth, Arch and Filbert streets, Mr. James M. Beck pleading the "Necessity of a City Hall Plaza."

The next plan proposed was that of Mr. William C. Huey, a member of Council, prepared by Messrs. Schermerhorn and Reinhold, for a concourse two hundred and seventyfive feet wide from the north side of Carleton street to the South side of Pearl street, extending from Broad street westward to Twenty-second street, where it turned northwestward, maintaining the same width, until it took the line of the Reading subway and reached the park by way of Pennsylvania avenue. A similar plan was later laid before Councils by Alexander Crow, Jr., but no action was taken on either.

On February 6, 1900, the Art Federation of Philadelphia met at the house of Mr. Daniel Baugh and invited delegates of various civic and art societies to meet at the Art 
Club in April to consider a new Parkway project. This was the real beginning of the present Parkway, as this organization formed the Parkway Association and on motion of $\mathrm{Mr}$. Beck approved a plan for a boulevard one hundred and sixty feet wide from the City Hall to Logan Square, and three hundred feet wide from Logan Square to the Park, with the suggestion of the location of the proposed Art Museum on the site of the Fairmount Reservoir.

In 1902 the Parkway Association, of which the late Mr. John H. Converse was President, issued a quarto pamphlet with illustrations of the proposed improvements in connection with the suggested Parkway, illustrating some of the prominent features of similar developments in leading cities of the world. The introductory plea by Mr. James M. Beck was a powerful argument for the adoption of the plan and its complete presentation by Mr. Albert Kelsey, the Secretary of the Parkway Association, produced a marked effect on public opinion. Mr. Converse was supported by an Executive Committee of men of prominence, who united in urging the forwarding of the project, giving it all necessary financial assistance.

On March 19, 1903, the City Councils passed an ordinance authorizing the placing "on the City Plan of an Avenue or Parkway between City Hall and Fairmount Park," the width to be 160 feet east of Logan Square and 300 feet west of Logan Square. The ordinance was somewhat amended on June 27, 1904, and the plan, made to conform with the amended ordinance, was confirmed by the Board of Surveyors November 7, 1904.

On May 18, 1904, a loan ordinance was submitted to the electors, which included $\$ 2,000,000$ for the Parkway, and the electors approved it. This was the first money voted for the project by the people.

A revision of the lines and grades of the Parkway was made by an ordinance approved January 4, 1906, and the revision was confirmed by the Board of Surveyors on April 9, 1906. On October 13, 1906, the first ordinance authorizing the opening of any portion of the Parkway was passed. It directed its opening between Logan Square and Spring Garden Street. The city filed its bond in the sum of $\$ 2,000,000$ in the Court of Quarter Sessions under date of November 22, 1906. This condemnation by the city was under the plan confirmed April 9, 1906.

On December 12, 1907, the Fairmount Park Art Associa- 
tion presented the plan prepared for it by a commission cor1sisting of Paul P. Cret, Horace Trumbauer and C. C. Zantzinger. It is this plan, somewhat enlarged by Jacques Gréber, which is now being carried out; but it is still essentially the plan presented by this Association. The plan was not only printed in the Association's Annual Report for the year 1907, but it was also reproduced in a special book, published by the Association in 1919, entitled "The Fairmount Parkway 1904-1919*."

On April 15, 1908, a loan was submitted to the people, including an item of $\$ 1,000,000$ for the Parkway, which was duly approved, and a similar loan was authorized by Councilmanic authority July 1, 1909. Before the latter action was taken, an ordinance approved June 8, 1909, authorized a revision of the lines and grades of the Parkway, which revision was confirmed by the Board of Surveyors on September 20, 1909. It is this revision, which adopted the plan prepared for this Association by Messrs. Cret, Trumbauer and Zantzinger. The submission of this plan was a unique public service rendered by the Association and its success was due to the public-spirited vision of the late Mayor, John E. Reyburn, who did more for city planning in Philadelphia than any other mayor we have ever had. His reputation for foresightedness will grow as time passes.

By an ordinance approved June 1, 1909, the Mayor, the City Solicitor and the City Controller were authorized to enter into negotiations for the purchase of property within the Parkway or within 200 feet thereof. This ordinance was amended by an ordinance approved December 9, 1909.

The ordinance of April 8, 1911, set aside as a site for the Free Library the plot of ground on the north side of Vine Street between 19th and 20th Streets. An ordinance approved April 15, 1911, authorized the purchase of property at the southwest corner of Broad and Arch Streets for the Parkway under a programme which was excellent in that it spread the payment for the property over a period of ten years. On June 19,1911 , the people approved a loan containing $\$ 1,000,000$ for the Parkway. On July 22nd of the same year an ordinance was passed to condemn the property bounded by Twentyfirst Street, Vine Street, the Parkway, Twentieth Street and Summer Street and a line 200 feet southwest of the Parkway, but nothing was done under this ordinance.

\footnotetext{
*See Frontispiece of this volume.
} 
On August 4, 1911, an ordinance to open so much of the Parkway, as was bounded by Callowhill Street, Twentysecond Street, Shamokin Street and the southwesterly line of the Parkway, was approved. On July 3, 1912, an ordinance was approved to open the Parkway between Sixteenth and Appletree Streets. On July 2, 1914, the remaining portion of the block between Sixteenth and Seventeenth Streets was ordered opened. Another ordinance was approved, on the same date, to open the Parkway between Nineteenth and Twenty-second Streets, and on May 20, 1915, an ordinance was passed to enlarge Logan Square by extending it to Twentieth Street and to place the Square and the Parkway under the care and management of the Commissioners of Fairmount Park.

On January 7, 1915, the people approved at the polls a loan of $\$ 800,000$ for the Parkway and on June 29, 1916, $\$ 9,000,000$ were added for the same purpose also by vote of the people. On July 24, 1916, an ordinance was passed authorizing the opening of the unopened portions of the Parkway between Broad Street and Fairmount Park. On December 31, 1917, an ordinance to condemn property at the southwest corner of the Parkway and Twenty-second Street was passed and another ordinance appropriating the southwest corner of 18th Street and the Parkway was approved July 18, 1919. A Councilmanic loan on January 7, 1918, provided \$913,172.86 for the Parkway and on December 15, 1919 , another Councilmanic loan provided $\$ 1,761,911.26$ for it.

The first loan issued for the Art Museum was for $\$ 200,000$ in 1897. The abandoned Fairmount Reservoir was set aside as a site for the Art Museum during 1911. During 1913 preparatory work was begun on the grading for the Plaza in front of the Museum and in the loan of $1914 \$ 800,000$ were made available for construction of the Museum, $\$ 1,000,000$ in the loan of 1916 and $\$ 1,500,000$ in the loan of 1920 . An ordinance of July 18, 1911, provided a site for the Hall of the American Philosophical Society on the northeast side of the Parkway west of Sixteenth Street; a convention hall site was set aside by the ordinance of February 18, 1916; and a site for the Municipal Court by the ordinance of July 18, 1919.

The plan prepared by M. Jacques Gréber was submitted in 1918. Its execution required the acquisition of more property on the southwest side of the Parkway and an ordinance approved December 17, 1919, provided for the appropriation 
of the ground bounded by Twenty-third Street, Callowhill Street, Fairmount Park and the Parkway.

The foregoing is a somewhat statistical history of the development to date of the greatest single improvement of the kind of the Twentieth Century.

The embellishment of the Parkway with trees, flowers, fountains and sculpture, as proposed in the Gréber plan, has been begun, but it will necessarily take several years to complete it. 


\section{LIST OF ANNUAL ADDRESSES}

At the annual meetings of the Association, addresses have been given by men of national reputation on varied topics, always of interest and value to the members and their guests. In some cases no title was given to the address by the speaker.

The list, with the respective dates, follows:-

\section{FIRST ANNUAL MEETING}

October 15, 1872. Hon. Benjamin Harris Brewster.

"Emblems of moral excellence and public good, such as this Park and its embellishments, should adorn our country, to remain as perpetual witnesses of our tone."

\section{SECOND ANNUAL MEETING}

October 28, 1873. Rev. A. A. Willits.

"And let us do all in our power to bless, to exalt, to ennoble the beautiful city of our habitation and the noble land, which with so much joy and pride we call 'Our Country."'

\section{THIRD ANNUAL MEETING}

December 10, 1874. Hon. Henry C. Carey.

"It is needed that we strive by every effort in our power to make our city not only comfortable for ourselves, but attractive to those abroad."

\section{Provost Charles J. Stille.}

"Everything presented to the popular eye as a work of art should suggest noble thoughts and associations of a lofty kind, and therefore fitting to be clothed with that grace and beauty, with which the human heart seeks to invest everything which it truly reveres and loves."

From the year 1874 until the year 1893 the minutes record brief comments by those in attendance at the Annual Meetings, but formal addresses were not delivered.

\section{TWENTY-FIRST ANNUAL MEETING}

March 2, 1893. Leslie W. Miller.

"Let us do what we can to make the streets and parks of our city beautiful, not only for the purpose of attracting desirable residents and visitors, but as a means of nourishing the deepest and most vital sources of our industrial energy." 
TWENTY-SECOND ANNUAL MEETING

May 10, 1894. Leslie W. Miller.

$$
\text { "A Lesson from Florence." }
$$

"Other, though not many, cities have histories as noble, treasures as vast, but no other city has them living and ever present in her midst, familiar as household words and touched by every baby's hand and peasant's step."

Hon. James M. BECK.

"The artistic decoration of the interior of our new City Hall by mural paintings."

\section{TWENTY-THIRD ANNUAL MEETING}

April 29, 1895.

Informal addresses were made by Mrs. E. D. Gillespie, Mr. Leslie W. Miller, Mr. Daniel Baugh, Mrs. Mary E. Mumford, Mr. Talcot Williams, Mrs. Aubrey H. Smith, and Rev. Leverett Bradley.

\section{TWENTY-FOURTH ANNUAL MEETING}

December 28, 1895 . Charles S. Keyser.

"Historic Mansions in Fairmount Park."

A scholarly address, replete with interesting information, historic and traditional.

\section{TWENTY-FIFTH ANNUAL MEETING}

May 26, 1897. John SARTain.

"Reminiscences of Philadelphia sixty years ago," from Mr. Sartain's unpublished Memoirs.

TWENTY-SIXTH ANNUAL MEETING November 11, 1897. Ernest Thompson Seton.

"The Art of the Stone Age, or Earliest Known Drawings."

\section{TWENTY-SEVENTH ANNUAL MEETING}

November 29, 1898 . Edward H. Coates.

"That which befits us, embosomed as we are in beauty, is courage and hope and the endeavor to realize our aspirations."

TWENTY-EIGHTH ANNUAL MEETING January 27, 1900. TRUMAN H. BARTLETT. "Barye and his Work."

"The most thoughtful professional judgment marks his fame as that of the greatest sculptor of ferocious animals, of which history gives any distinct account, as one of the 
great artists of the world, and, so far as his art was concerned, equally great as a man."

\section{TWENTY-NINTH ANNUAL MEETING}

December 19, 1900. Professor Charles E. Dana. "Arms, Armour and Display in the Middle Ages."

Professor Dana was a past master upon this subject (as also upon many others); the address was printed in the 1901 Report, No. 35, and attracted wide attention both here and abroad.

\section{December 14, 1901. WALTER Cope. \\ "The Relation of Natural to Artificial Beauty \\ in Landscape."}

Mr. Cope was an architect of distinguished ability, as evidenced by many structures of grace and beauty that adorn Philadelphia and other cities.

"I would urge that we take nature as we find her, treat her with respect, allow her free sway and that in all we do of artificial work we do with an eye to the eternal fitness of things, not hoping to improve upon nature, but merely to make beautiful works of our own."

\section{THIRTY-FIRST ANNUAL MEETING}

December 18, 1902. Albert Kelsey.

"Parkways and Monumental Thoroughfares."

Mr. Kelsey has achieved repute by many architectural creations here and elsewhere, but none more noted than the Pan-American Building in the City of Washington, in the design of which he was an associate of Professor Cret.

$$
\begin{aligned}
& \text { "Hon. James M. Beck. } \\
& \text { "A Plea for the Parkway." }
\end{aligned}
$$

The progress of this important artery in the centre of Philadelphia and its near accomplishment is due in large measure to Mr. Beck's earnest and continuous advocacy of the plans supported by this Association.

\section{THIRTY-SECOND ANNUAL MEETING} December 10, 1903.

Hon. James M. Beck, as President of the Association.

James MacAlister, LL.D.

Mayor John Weaver,

Col. A. Loudon Snowden, President, Commissioners of Fairmount Park.

Francis La Flesche. 
"Man's strength contrasted with the power of the 'Great Spirit.' With his best intelligence and greatest skill in the use of his hands, man is powerless to bring into existence the tiniest flower, while out of the force of the will of the Mysterious One all things in the heavens and the earth have come into existence with beauty, grandeur and majesty."

\section{THIRTY-THIRD ANNUAL MEETING} December 16, 1904. Frederick Law Olmsted, JR. "Progress in the Development of Park Systemsthe Washington Example."

"It is at Washington, as at Philadelphia, to forestall open spaces before built upon; to secure vital park connections before the beautiful valleys through which they ought to run are effaced by spreading streets, the outgrowth of city blocks."

\section{THIRTY-FOURTH ANNUAL MEETING December 18, 1905. Frank Miles Day. \\ "City Planning."}

Mr. Day attained a position in the front rank of American architects and devoted much time and energy to public improvements, giving of his services freely and without compensation.

\section{THIRTY-FIFTH ANNUAL MEETING}

December 19, 1906. Frederic Crowninshield.

"The Fine Arts Federation, its Aims and

Ambitions," by its President.

"The Place and Function of a Municipal Art Gallery."

The address was followed by brief remarks from representatives of art organizations of the city.

Mr. Јонn H. Converse, for the Pennsylvania Academy of the Fine Arts. Professor Herbert Everett, for the University of Pennsylvania.

Mr. Leslie W. Milder, for the Pennsylvania Museum and School of Industrial Art.

James MacAlister, LL.D., for the Drexel Institute.

Mr. Elliott Daingerfield, for the School of Design for Women.

Mr. James P. Jamieson, for the Philadelphia Chapter, American Institute of Architects.

Mr. Thomas M. Kellogg, for the T-Square Club.

Miss Florence W. Fulton, for the Plastic Club.

Mr. Ludwig E. Faber, for the Philadelphia Sketch Club. 


\section{THIRTY-SIXTH ANNUAL MEETING}

December 12, $1907 . \quad$ R. A. CRAM, F.A.I.A., F.R.G.S.

"No man is at liberty to block a scheme of public improvement for his own selfish desires. The individual must realize that he is simply a part of civilized society and in the end we shall all realize that schemes of municipal improvement, however much they may argue for themselves in the line of practicality or æsthetic value, are yet, when you analyze, really and primarily first lessons in good citizenship."

\section{THIRTY_SEVENTH ANNUAL MEETING} January 27, 1909. Charles H. Caffin.

\section{"Mural Decorations of Municipal Buildings."}

Mr. Caffin was a well-known writer on art and had a wide knowledge of this subject.

"You can find no nobler way of employing the arts than by putting into the schools of Philadelphia mural paintings that shall be suggestive of the beauty of nature and the beauty of the realism of our race and country."

\section{THIRTY-EIGHTH ANNUAL MEETING}

January 11, 1910. Sylvester Baxter, Secretary of the Park Commission for Greater Boston.

\section{"The Development of the Parkway."}

"I congratulate you upon the assured realization of your magnificent project, for which you are inexpressibly indebted to the public spirit and the splendid perseverance of many of your best citizens, inspired by the graphic and beautiful presentations of the architects, who so admirably conceived it."

George Oakley Totten, Jr., A.M., A.A.I.A., Secretary, American Section, International Congress of Architects. "The Influence of Aeronautics on City Building."

"If a large city is to be maintained as a single, unified organization, it must of necessity have a civic centre or heart, which may not be at its centre of population, but must be at or near the centre of its commercial, financial and industrial activities. On this middle ground should be placed its chief public buildings."

\section{THIRTY-NINTH ANNUAL MEETING}

January 24, 1911. Hon. John E. Reyburn, Mayor of Philadelphia.

"This project of an Art Gallery is one that has been close 
to our hearts; we are nearer a solution of the problem today than we have been at any time."

\section{Alfred H. Granger.}

"Throughout the country, east and west, the Pennsylvania Academy of the Fine Arts is admired and loved because of the spirit of fairness and justice always shown at its annual exhibitions, which spirit makes all artists desirous of recognition here, as to have been hung at an Academy Exhibition in Philadelphia gives cachet to an artist not only in our own country but in Europe as well."

\section{Hon. James M. Beck.}

"We honor Venice and Florence and Rome, because they have those treasures of art, which, after all, mark the æsthetic idealism of civilization.

"They touch the deep note of the beautiful in human imagination; and that American city, which will first awaken to the value of the things that truly last, which will first awaken to the fact that art, literature and science are worth all the more material advantages, - that city in the long race for supremacy in this country will be ultimately the triumphant one. If you will join hands and erect here a great and noble museum of art, then Philadelphia will be making a long stride forward in taking the great place which rightfully belongs to it in the world."

\section{Charles J. Cohen.}

"An historical sketch of Carpenters' Hall, apropos of the Association's recent purchase of adjoining property (and its subsequent demolition) to protect this historic landmark."

\section{FORTIETH ANNUAL MEETING}

January 15, 1912. Col. William C. Church, Editor, Army and Navy Journal.

"Fohn Ericsson, the Creator of the Modern Navy."

"You can make no mistake in placing among the adornments of your magnificent park a memorial to John Ericsson. Posterity will never question his claim to such a recognition, as you propose to give him as one of America's greatest sons. The nature of his service to the country and to humanity was such as to demand and to receive the reward of a public recognition seldom accorded to any man."

FORTY-FIRST ANNUAL MEETING

January 16, 1913. Dr. James MacAlister.

"Outlining opportunities for future usefulness by the Association." 


\section{FORTY-SECOND ANNUAL MEETING}

January 22, 1914.

A general discussion as to the activities of the Association, participated in by Hon. George W. Norris, who called particular attention to the contemplated improvements in the southern part of the city, many of which have since been accomplished; William H. Connell, Esq., Chief of the Bureau of Highways; Eli Kirk Price, Esq., of the Art Jury and Fairmount Park Commission; Andrew Wright Crawford, Esq., Secretary of the Art Jury and of the City Parks. Association of Philadelphia; and Mr. Albert Kelsey, who paid a warm tribute to Professor Paul P. Cret of the University of Pennsylvania, to whose efficient and unselfish service the city was indebted for much of the improvement in public and semi-public structures, that had been noted in the report.

\section{January 21, 1915.}

\section{FORTY-THIRD ANNUAL MEETING}

A general discussion as to City Planning, a movement throughout the country in which this Association is universally regarded as the leader.

\section{FORTY-FOURTH ANNUAL MEETING}

January 29, 1916.

An appeal for the completion of the Permanent Fund, City Branch, so that its income might be available for the adornment of the city proper.

\section{FORTY-FIFTH ANNUAL MEETING}

January 18, 1917. Wilfred H. Schoff, Secretary of the Philadelphia Commercial Museums.

"Out of Doors in Portugal and Spain," illustrated with attractive lantern slides.

\section{FORTY-SIXTH ANNUAL MEETING} January 30, 1918. "Joseph Aldison Steinmetz.

Mr. Steinmetz illustrated with lantern slides the rapid advance that had been made in aerial navigation and stated the necessity for provision in the architecture of the near future for the use of planes in towns and cities to accommodate the various classes certain to require such facilities.

Mr. Joseph E. Widener referred to the nature and extent 
of the work that had been done recently in developing the studies for the Parkway and the river embankments.

He called attention to the comprehensive scheme prepared for the Commissioners of Fairmount Park by the distinguished landscape architect, Mr. Jacques Gréber, whose designs were publicly exhibited for the first time at this meeting.

\section{FORTY-SEVENTH ANNUAL MEETING} January 16, 1919. Albert Kelsey.

\section{"Memorials."}

"Let Philadelphia have its Temple of Victory at one end of its Peace Parkway and its great Art Museum at the other."

"A memorial is a sacramental thing and therefore it must be a delight to the eye, a moral lesson and something for the heart to rejoice in."

\section{FORTY-EIGHTH ANNUAL MEETING}

January 15, 1920. Hon. Gifford Pinchot.

"Forest Planting in Parks and Highways."

"Would it be possible, without injury to the beauty of Fairmount Park, to let it tell some part of the story of the forest to the tens of thousands of city dwellers for whom it is the nearest approach to the great outdoors?"

"Adopt a descriptive label, giving the uses made of the tree (and those the Indians made before us), its value for planting and shade, and interesting items as to its insect and animal inhabitants."

"The reforestation of six million acres in Pennsylvania is imperative, if the supply of lumber is to be maintained, aside from its importance for the future water supply for Philadelphia."

\section{FORTY-NINTH ANNUAL MEETING}

January 13, 1921. ANDREW Wright CRAWFord.

"World's Fairs and their City Planning Salvage."

A plan, showing the advantage of the Fairmount Parkway and the banks of the Schuylkill as the site for the World's Fair to be held in 1926 in celebration of the One hundred and fiftieth Anniversary of American Independence, prepared by Paul P. Cret, Sc. D., was exhibited.

\section{FIFTIETH ANNUAL MEETING}

January 26, 1922. Eli Kirk Price.

"Fairmount Park and the Sesqui-Centennial."

Mr. Price's address was followed by a discussion by Hon. James M. Beck. 


\title{
FAIRMOUNT PARK ART ASSOCIATION
}

\author{
October 31, 1921
}

The balances in the various funds are as follows:

\begin{tabular}{|c|c|c|c|c|c|c|c|}
\hline \multirow[t]{2}{*}{ Accounts } & \multirow{2}{*}{$\begin{array}{l}\text { U. S. } \\
\text { Liberty } \\
\text { Loans }\end{array}$} & \multicolumn{3}{|c|}{$\begin{array}{l}\text { Philadelphia } \\
\text { Loans }\end{array}$} & \multirow{2}{*}{$\begin{array}{l}\text { Mort- } \\
\text { gages }\end{array}$} & \multirow[t]{2}{*}{ Cash } & \multirow[t]{2}{*}{ Total } \\
\hline & & $4 \%$ & $31 / 2 \%$ & $5 \%$ & & & \\
\hline \multirow{4}{*}{$\begin{array}{l}\text { Permanent Fund .. } \\
\text { (Park Branch) } \\
\text { Permanent Fund. } \\
\text { (City Branch) } \\
\text { General Fund.... } \\
\text { (Park Branch) }\end{array}$} & $\$ 42,817.63$ & $\$ 26,652.38$ & $\$ 38,160.47$ & $\$ 3,016.10$ & $\$ 10,400.00$ & $\$ 206.70$ & $\$ 121,253.28$ \\
\hline & $4,133.11$ & $4,571.87$ & $12,637.98$ & & $1,000.00$ & 459.14 & $22,802 \cdot 10$ \\
\hline & $13,881.16$ & 4.840 .00 & $6,518.57$ & & $4,000,00$ & 3.410 .38 & $32,650.11$ \\
\hline & & & & & & (Dr. Bal.) & $82,000.11$ \\
\hline \multirow{9}{*}{$\begin{array}{l}\text { General Fund...... } \\
\text { (City Branch) } \\
\text { Ericsson Memorial } \\
\text { Fund............ } \\
\text { Childs-Drexel Me- } \\
\text { morial Fund....... } \\
\text { Robert M orris Me- } \\
\text { morial Fund........ } \\
\text { Hancock Memorial } \\
\text { Fund............ } \\
\text { G. and M. Connor- } \\
\text { Wood Me m or ia } 1 \\
\text { Fund............ } \\
\text { Aero Memorial Fund } \\
\text { Shakespeare Memo- } \\
\text { rial Fund......... }\end{array}$} & 400.00 & & & & & $1,530.09$ & $1,130.09$ \\
\hline & & & & & & & \\
\hline & & & $8,629.25$ & & & & \\
\hline & 409.54 & $3,248.12$ & & & & 152.03 & $3,809.69$ \\
\hline & 91.08 & 602.87 & & & & 35.18 & 729.13 \\
\hline & 275.14 & 202.26 & $1,870.98$ & & & 103.72 & $2,452.10$ \\
\hline & 400.00 & 102.87 & & & & $\begin{array}{l}28.61 \\
42.02\end{array}$ & $\begin{array}{l}131.48 \\
442.02\end{array}$ \\
\hline & $2,485.03$ & $11,073.13$ & $7,627.50$ & & & 105.53 & $21,291.19$ \\
\hline & & & & & & $\begin{array}{ll}\text { Cr. } & \\
\text { Dr. } & 5,058.46 \\
& 1,530.09\end{array}$ & $\begin{array}{l}\text { Cr. } \\
228,437.20 \\
\text { Dr. } \\
\quad 1,130.09\end{array}$ \\
\hline Totals & $\$ 70,988.26$ & $\$ 58,929.63$ & $3 \$ 75,444.75$ & $\$ 3,016.10$ & $\$ 15,400.00$ & $\$ 3,528.37$ & $\$ 227,307.11$ \\
\hline
\end{tabular}

BEQUESTS TO THE FAIRMOUNT PARK ART ASSOCIATION 1892. Alfred Bamber, placed in the Permanent Fund, Park Branch. . . . . . . . . . . . . . . . . . . . . . . . . . \$ \$8000.00

1906. J. Dundas Lippincott, placed in the Permanent Fund, Park Branch ... . . . . . . . . . . . . . . . . . . . . . 5000.00

1916. George and Meta Connor-Wood Memorial Fund....... 113.32

1918. Otto Bachmeister (on the termination of certain life interests)............................... 2000.00

1913. Ellen Phillips Samuel (on the death of her husband, J. Bunford Samuel) ........................ 765,000.00 


\section{PREAMBLE TO THE ORIGINAL CONSTITUTION}

Since it is desirable to increase the appreciation and love of art in our midst, to add to the number of its votaries, promote the refinements of life consequent thereon and encourage artists in the practice of their profession, and

Since it is commendable to erect statues, busts, fountains and other works of art to the honor and memory of eminent persons and their deeds, in order that their good example and influence may be more permanently exerted in fostering a spirit of emulation and ambition in our people, and

Whereas these results may be better secured and the good effects thereof more generally obtained by the accumulation of objects of art in one enclosure, visited by the greatest number of people, and

Whereas it is desirable to enhance the beauties and attractions of the Park, by means in which all may gladly participate;

Therefore, we, whose names are affixed to the following Constitution, have formed ourselves into a society to be styled the "Fairmount Park Art Association," which society shall have for its object the accumulation of a fund, by means of annual contributions of small fixed sums of money by the members thereof, and by legacies, donations, etc., which fund shall be devoted to and employed in adorning Fairmount Park with works of art, either of a memorial nature or otherwise.

In consideration of the objects above set forth, we, whose names are subscribed to the following Constitution, agree to fulfil with honor and good faith the duties imposed in the said Constitution and the By-Laws, which have been adopted for the rule and government of the said Fairmount Park Art Association. 


\section{CLASSES OF MEMBERSHIP}

\section{PARK BRANCH}

Associate Membership (Annually) ..............\$ 1

Annual Membership.......................... 5

Life Membership (and Certificate) .............. 50

*Perpetual Membership......................500

\section{CITY BRANCH}

Associate Membership (Annually) ............. 1

Annual Membership....................... 5

Life Membership (and Certificate) ............ 50

*Perpetual Membership........................500

Annual members of two or more years may change to Life Membership upon payment of Forty Dollars.

As the Association welcomes gifts and bequests of securities, money and real estate, it is hoped that all who desire to perpetuate the work of the Association will, in disposing of their property, include the Fairmount Park Art Association among their beneficiaries.

Under the laws of Pennsylvania, which provide that the courts are authorized to enter a decree at any time extending and defining the amount of property which the Association shall be permitted to hold, it is evident that the restriction in the original charter limiting the amount of real estate which it may legally hold is practically removed.

Perpetual memberships are especially valued as legacies.

Citizens desiring to contribute to the adornment of the park or city are invited to do so through the agency of this Association, in order that such undertakings may not only benefit by its experience and oversight, but also that proper and permanent record of them may be made in its published reports. 


\section{PERMANENT ENDOWMENT FUND}

This fund was created in the year 1874, by a resolution of the Board of Trustees, which appropriated the sum of $\$ 3,000$ as a nucleus.

All amounts received from Life Memberships, ten per centum of the annual dues of members, together with all special donations, are added to this fund.

In 1895 the special form of membership known as "Perpetual Members" was adopted, all sums received in connection therewith to become a part of the Permanent Fund. Perpetual membership may either be in one's own name or "In Memoriam."

\section{PERPETUAL MEMBERS}

Park Branch

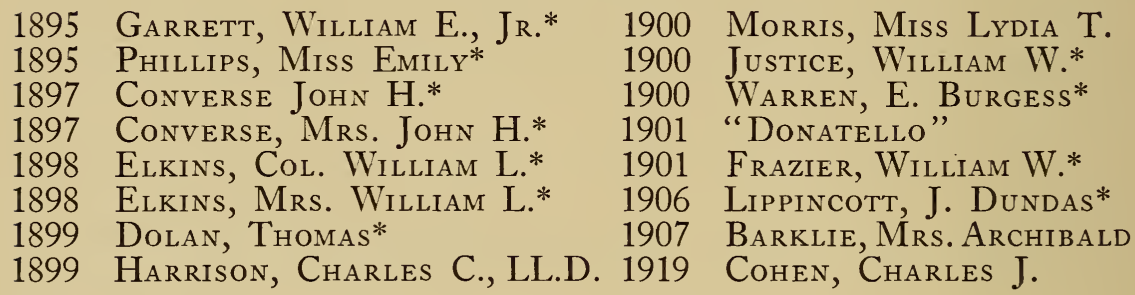

\section{PERPETUAL MEMBERS IN MEMORIAM} Park Branch

1895 Bamber, Alfred

1895 Smith, Richard

1895

1895

1898

1898

1900 Morris, IsaAc W., Jr.

1900 Dreer, Mrs. Ferdinand J.
1901 Justice, Miss Cecilia

1901 Thomson, J. Edgar

1901 Drexel, Anthony J.

1901 Scott, Col. Thomas A.

1904 Henry, Charles W.

1904 Howell, Col. Charles H.

1906 Dundas, James

City Branch

1904 Howell, Col. Charles H.

${ }^{*}$ Deceased. 


\section{HONORARY MEMBERS}

1899 Hampton L. Carson

1906 Henry K. Fox

1920 Leslie W. Miller

\section{LIFE AND ANNUAL MEMBERS}

This list represents the Membership in 1921

Members will please notify the Secretary of any change or error in address.

The fee for Life Membership in either Branch is fifty dollars, one hundred in both. That for Annual Membership is five dollars in either Branch, ten in both.

$P L$ indicates $P A R K$ branch LIFE member.

$C L$ indicates CITY branch LIFE member.

$P A$ indicates $P A R K$ branch $A N N U A L$ member.

$C A$ indicates $C I T Y$ branch $A N N U A L$ members

* indicates DECEASED.

P a Аввотt, Francis R., The Art Club, 220 S. Broad St.

P L AdDicks, J. Edward.*

P A Albrecht, Emil P., The Bourse.

P a Alburger, Stoer \& Co., 615 Chestnut St.

P a Allman, Herbert D., 3819 Walnut St.

c a Allman, Herbert D.

p l Alter, John Joseph, 935 N. Twenty-ninth St.

P L Alter, Mrs. John Joseph, $935 \mathrm{~N}$. Twenty-ninth St.

P a Archambault, V. E., Jr. (In Memoriam.)

P a Armstrong, Theodore, 115 Chestnut St.

P a Ashton, Mrs. Thomas G., 1814 S. Rittenhouse Sq.

p a Austin, Richard L., 408 Chestnut St.

C a Bailey, Charles W., P. O. Box 197.

C a Bailey, Edward L., Fallsington, Pa.

P l Baird, Charles O.*

P A Baird, John E., 306 Real Estate Trust Bldg.

C a BaIrd, John E.

P a Baird, Mrs. Matthew, 2012 Spruce St.

P L Baltz, J. \& P., Brewing Co., Thirty-first and Thompson Sts.

P L Banks, George W., 1218 Chestnut St.

P a Barney, Charles D., Ogontz, Pa.

C a Barney, Charles D.

P l Barrie, George, 1313 Walnut St.

*Deceased. 
P l Barrows, Mrs. Ira, 667 Fifth Ave., New York City.

P l Battles, H. H., 114 S. Twelfth St.

P L Baugh, Daniel, 1601 Locust St.

C a Baugh, Mrs. Daniel, 1601 Locust St.

P a Beck, Hon. James M., 32 Liberty St., New York City.

C a Beck, Hon. James M.

p a Beeber, Dimner, 705 Land Title Bldg.

C a Beeber, Dimner.

P L Bein, August, S. W. cor. Fifth and Cherry Sts.

C l Bell, Miss Emily, 1428 Spruce St.

P l Bell, Miss Laura, 1428 Spruce St.

P L Bement, Clarence S., 401 N. Twenty-first St.

P l Bement, William P., 3817 Spruce St.

C l Benson, Alexander, 59 S. Fourth St.

P a Benson, Gen. R. Dale, 1060 Drexel Bldg.

P l Bergdoll, Louis, Jr., 2806 Parrish St.

P l Berges, William, 1500 Erie Ave.

c a Biddle, Mrs. Edward W., The Rittenhouse.

P L Bisler, Gustav A., 249 N. Sixth St.

C l Bisler, Gustav A.

P a Black, Francis F., 620 S. Washington Sq.

C L Blakiston, Miss Mary, Fort Washington, Pa.

C a Bockius, Morris R., 934 Land Title Bldg.

P a Bodine, Samuel T., Villa Nova, Pa.

C L Bond, Miss Catharine A., 1608 Locust St.

P a Borgner, Cyrus, Twenty-third and Race Sts.

P a Borie, Charles L., Jr., 112 S. Sixteenth St.

c a Borie, Charles L., Jr.

c a Brazier, H. Bartol, Wynnewood, Pa.

P l Brock, Mrs. Robert C. H., 1612 Walnut St.

c l Brock, Mrs. Robert C. H.

p a Bromley, Joseph H., Wissahickon and Chelten Aves., Germantown.

C a Bromley, Joseph H.

P l Brooks, William H., 509 Chestnut St.

P a Brown, Francis Shunk, 5927 Drexel Road, Overbrook.

P L Brown, Јohn A., 224 S. Nineteenth St.

P A Bucknell, Mrs. W., Care of Fidelity Trust Co.

C a Bucknell, Mrs. W.

P a Burnham, William, 4301 Spruce St.

C a Burnham, William.

P L Burns, Charles M., 212 S. Fifteenth St.

p a Busch, Mrs. Henry E., 1006 Spruce St.

c a Busch, Mrs. Henry E.

P l Busch, Henry Paul, 1006 Spruce St.

P a Calder, Alexander Stirling, 51 W. Tenth St., New York.

P a Cannstatter Volksfest-Verein, 1637 N. Broad St.

C a Cannstatter Volksfest.-Verein.

p l Capp, Seth Bunker, P. O. Box 2054, Philadelphia.

C l Capp, Seth Bunker.

p l Castner, Samuel, Jr., 3729 Chestnut St.

C a Castner, Samuel, Jr.

P l Chandler, Alfred N. 
C l Chandler, Alfred $\mathrm{N}$.

P l Chandler, T. P., 249 S. Sixteenth St.

p a Chipman, Charles, R. F. D. 1, Easton, Pa.

P A Church, Arthur L., 500 N. Broad St.

p a Clark, Mrs. C. Howard, Jr., 1520 Spruce St.

p a Clark, C. M., 321 Chestnut St.

C A Clark, C. M.

p a Clark, Mrs. Edward Walter, Chestnut Hill.

p a Clark, Herbert L., 321 Chestnut St.

p a Clark, Percy H., 321 Chestnut St.

c a Clark, Percy H.

P A Class \& Nachod, 1729 Mervine St.

P l Clothier, Mrs. Conrad F., 844 N. Broad St.

P A Clothier, Isaac H., Wynnewood, $\mathrm{Pa}$.

C A Clothier, IsaAc H.

c l Clothier, Morris L., 801 Market St.

p a Coates, Edward H., Penna. Co., 517 Chestnut St.

C a Coates, Edward H.

P l Coates, William M., 127 Market St.

P a Cohen, Charles J., 1520 Spruce St.

c a Cohen, Charles J., 1520 Spruce St.

P l Colket, C. Howard, 2008 De Lancey Pl.

P l Collins, Henry H., 226 Columbia Ave.

p a Colton, Sabin W., Jr., Bryn Mawr, Pa.

c a Colton, Sabin W., Jr.

P A Combs, John F., 119 S. Fourth St.

p a Combs, Mrs. John F., 119 S. Fourth St.

p a Comly, Robert, 3311 Arch St.

P l Corlies, Miss Margaret L., 264 S. Twenty-first St.

P l Corlies, Mrs. S. Fisher, 264 S. Twenty-first St.

C l Coxe, Alexander Brown, Paoli, Pa.

c l Coxe, Mrs. Alexander Brown, Paoli, Pa.

p a Craig, John F., 3417 Baring St.

p a Crawford, Andrew Wright, 701 Stephen Girard Bldg.

C a Crawford, ANDrew Wright.

c a Cret, Professor Paul P., University of Pennsylvania.

P A Croft \& Allen Co., Thirty-third and Market Sts.

C A Croft \& Allen Co.

P a Curtis, Cyrus H. K., Wyncote, Pa.

P A Cuyler, T. De Witt, Haverford, Pa.

P a Dana, Mrs. Charles E., 2013 De Lancey Pl.

C a Dana, Mrs. Charles E.

p a Davis, Charles Gibbons, 8204 Seminole St., Chestnut Hill.

C a Davis, Charles Gibbons.

p l Davis, Henry J., Lansdowne, $\mathrm{Pa}$.

P A Day, Mrs. Frank Miles, Allen's Lane, Mt. Airy.

De Armond, Mrs. George J., Merion, Pa.

P l Dick, Mrs. William A., Chestnut Hill.

P l Dilley, Franklin P., 210 S. Front St.

P L Disston, Jасов S., 1130 Real Estate Trust Bldg.

c a Disston, Jacoв $\mathrm{S}$.

p a Dobson, James, 28 N. Front St. 
P a Dolan, Mrs. Thomas, 1809 Walnut St.

C a Dolan, Mrs. Thomas.

P L Doll, Miss Josephine, 3411 N. Seventeenth St.

P l Doll, Miss Matilda, 3411 N. Seventeenth St.

P a Donohough, Miss Emma Edith, Cynwyd, $\mathrm{Pa}$.

P A Dougherty, John A.*

C A Dougherty, Miss L. A., 1532 Green St.

P l Dreer, Edwin Greble, Malvern, Pa.

C l Dreer, Edwin Greble.

P l Dreer, William F.*

c a Dreka, Louis, The St. James Hotel.

P A Drexel, Anthony J., 112 Drexel Bldg.

c a Drexel, Anthony J.

P a Drexel, G. W. C., Estey Bldg., 1701 Walnut St.

c a Drexel, Mrs. G. W. C., Eighteenth and Locust Sts.

P a Drexel, John R., 112 Drexel Bldg.

P a Drexel, Mrs. John R., 112 Drexel Bldg.

P L Ehret, M., Jr., \& Co., Inc., 950 Drexel Bldg.

P a Elkins, George W.*

C a Elkins, George W.*

P l Elliott, Miss Mary E.*

P a Elliott, William J., 1308 Spruce St.

P l Elverson, James Jr., 1109 Market St.

P a Elwyn, Mrs. Thomas Langdon, 1006 Clinton St.

P a Engart, John S., N. E. cor. Twelfth and Chestnut Sts.

P a Evans, Mrs. George B., The Bellevue-Stratford.

P a Fels, Samuel S., Thirty-ninth and Walnut Sts.

c a Fels, Samuel S.

P a Fels, Mrs. Samuel S., Thirty-ninth and Walnut Sts.

C a Fels, Mrs. Samuel S.

P l Fitzgerald, Harrington, $28 \mathrm{~S}$. Seventh St.

P a Flagg, Mrs. Stanley G., Jr., 1723 Spruce St.

c a Flagg, Mrs. Stanley G., JR.

P a Fletcher, Mrs. George A., 1631 Walnut St.

P a Folwell, N. T., 625 Chestnut St.

P A Foulke, J. Roberts, 409 Chestnut St.

P a Fowler, Charles H., 605 N. Eighth St.

P l Frazier, William W., 250 S. Eighteenth St.

C l Frazier, William W.

P L Fullerton, John, 1424 Girard Ave.

P a Fussel, Dr. M. Howard, 421 Lyceum Ave., Roxborough

P l Gallagher, Christopher A., 1152 S. Broad St.

P l Garden, William Morton, The Belgravia.

P l Garrett, Mrs. Walter, 404 S. Ninth St.

P L Garrison, David R., Radnor, $\mathrm{Pa}$.

P l Gaw, William H.*

p L Gazzam, Hon. Joseph M., 265 S. Nineteenth St.

P l Gest, Hon. John Marshall, City Hall.

P L Gest, William P., 325 Chestnut St.

p l Gibbs, William W., Pennsylvania Bldg.

c a Gibis, William W.

* Deceased. 
C a Gibson, Miss Mary K., 1612 Walnut St.

P l. Gillingham, Joseph E.

P a Gilpin, Mrs. Washington H.*

P a Gorham, Walter M., Commercial Trust Bldg.

P a Grafly, Charles, S. E. cor. Twentieth and Cherry Sts.

P a Graves, Nelson Z., Manheim St. and Wissahickon Ave., Germantown.

c a Graves, Nelson Z.

p a Greber, Jacques, 30 Avenue Malakoff, Paris.

c a Greber, Jaceues.

P L Griffiths, George, 2102 Spruce St.

P l Grubnau, Carl, 114 Arch St.

C l Grubnau, Carl.

P a Guernsey, Joseph C., M.D., Montgomery Ave., Bryn Mawr, Pa.

P l Hale \& Kilburn Mfg. Co., Eighteenth St. and Lehigh Ave.

c l Hale \& Kilburn Mrg. Co.

P a Hallowell, William S., 3305 Race St.

P l Harrah, Charles J.

P l Harris, Alan C., 119 S. Sixteenth St.

C l Harris, Alan C.

P a Harris, Albert H., 710 North American Bldg.

P l Harris, Henry Frazer, 1607 Walnut St.

p l Harris, Mrs. J. Campbell, 1607 Walnut St.

c l Harris, Mrs. J. Campbell.

c l Harrison, Alfred C., 1616 Locust St.

P l Harrison, Charles C., LL.D., 1618 Locust St.

C l Harrison, Charles C., LL.D.

P l Harrison, Mrs. Charles C., 1618 Locust St.

P a Harrison, George L., Jr., 400 Chestnut St.

P l Harrison, Mrs. John.*

P a Harrison, Thomas S.*

c a Harrison, Thomas S.*

P a Hastings, John V., 819 Filbert St.

P a Hastings, Robert E., 819 Filbert St.

P l Heed, Charles E., 119 S. Fourth St.

P l Henry, Mrs. Charles W., Chestnut Hill.

c l Henry, Mrs. Charles W.

P a Hensel, Colladay \& Co., Twelfth and Wood Sts.

P l Hentz, J. Henry, 1237 N. Broad St.

P a Hering, W. E., 112 N. Twelfth St.

c a Hering, W. E.

P l Herzog, George.

P L Hetherington, Albert G., 1701 Locust St.

P a Heyl, George A., 2122 Walnut St.

P a Hinchman, Miss Margaretta S., 3635 Chestnut St.

p l Hockley, Mrs. Thomas, Hotel Vendome, Boston, Mass.

P L Hookey, Anthony C., 2464 Frankford Ave.

p a Hopper, William G., \& Co., 28 S. Third St.

P a Horner, Samuel, Jr., 840 Land Title Bldg.

P a Horstmann, Walter, 1804 De Lancey Pl.

P a Horstmann, Mrs. William H., Overbrook.

${ }^{*}$ Deceased. 
P a Houston, Samuel F., 509 Real Estate Trust Bldg.

c a Houston, Samuel F.

P a Houston, William C., 122 W. Chelten Ave., Germantown.

c a Howell, Miss Anna H:, 5218 Germantown Ave., Germantown.

P l Howell, Mrs. Charles H., 1523 Walnut St.

c l Howell, Mrs. Charles H.

P a Howell, Edward I. H., 5218 Germantown Ave., Germantown.

p a Howell, Miss Josephine F., 1523 Walnut St.

c a Howell, Miss Josephine F.

P a Huneker, John F., The Art Club.

p a Huston, Joseph M., Oaks-Cloister, Germantown.

P a Hutchinson, Miss Margaretta, 1617 Walnut St.

C a Hutchinson, Miss Margaretta.

P a Jacobs, Mrs. Edward B., 1915 Spruce St.

c a Jacobs, Mrs. Edward B.

P L Jenks, John Story, Chestnut Hill.

P A Johnson, Alba B., Rosemont, Pa.

C A Johnson, Alba B.

P A Jones, B. Griffith, 905 Land Title Bldg.

P L Jordan, Mrs. G. Frederick, 922 Clinton St.

P l Justice, Theodore, $10 \mathrm{~W}$. Clapier St., Germantown.

P a Karcher \& Rehn Co., 1608 Chestnut St.

P L Keen, Edwin F., 1816 N. Broad St.

C L Keen, Edwin F.

p L Keen, Joseph S., 723 N. Sixth St.

P A Keene, George Frederick, 1012 Liberty Bldg.

P L Keith, Sidney W., 1820 De Lancey Pl.

C A Kelsey, Albert, Perry Bldg.

P L Ketterlinus, John Louis, 2016 Spruce St.

c a Keyser, Mrs. James D.*

P A Kohn, Adler \& Co., 722 Market St.

P L Ladner, Louis J., 2349 N. Twenty-first St.

P a Lea, Charles M., 960 Drexel Bldg.

c a Lea, Charles M.

P a Lea, Miss Nina, 2000 Walnut St.

C a Lea, Miss Nina.

P L LeE, Edmund J., M.D., 1812 Rittenhouse Sq.

P A Lewis, John Frederick, 1914 Spruce St.

C A Lewis, John Frederick.

p l Lewis, Mrs. John Frederick, 1914 Spruce St.

C L Lewis, Mrs. John Frederick.

P l Lewis, Richard A., Box 165, Beverly, N. J.

P A Link Belt Co., Nicetown.

C a Link Belt Co.

P a Linn, William B., 518 Real Estate Trust Bldg.

C a Linn, William B.

p a Lippincott, J. Bertram, 1712 Spruce St.

c a Lippincott, J. Bertram.

c a Lippincott, Mrs. J. Bertram, 1712 Spruce St.

P L Lippincott, Walter, 2101 Walnut St.

P a Lit Brothers, Eighth and Market Sts.

* Deceased. 
P a Lit, Samuel D., Eighth and Market Sts.

P L Lonergan, J. E., 211 Race St.

P L Longstreth, Howard, 1323 Walnut St.

P L Loper, Richard F., 6 N. Tallahassee Ave., Atlantic City, N. J.

P a Malone, Watson \& Son, $1001 \mathrm{~N}$. Delaware Ave.

P l Maloney, Martin, Land Title Bldg.

P l Maris, Thomas R., Beverly, N. J.

P l Mason, Prof. William A., 212 W. Chelten Ave., Germantown.

c l Mason, Prof. William A.

P A Melloy's, John M., Sons, 1421 Spring Garden St.

P l Mickle, Charles C., 3301 Race St.

P A Mifflin, Mrs. James, 1824 Spruce St.

P L Miles, Thomas, 1820 Arch St.

P l Miller, Leslie W., 320 S. Broad St.

P l Milne, Caleb J., Jr., 2029 Walnut St.

P l Milne, David, School House Lane, Germantown.

P a Montgomery, Dr. E. E., 1426 Spruce St.

c a Montgomery, Dr. E. E.

P l Moore, Mrs. Alfred F., 1921 Walnut St.

P l Moore, Clarence B., 1321 Locust St.

P L Moore, Joseph, Jr., 1821 Walnut St.

P l Moore, Mrs. Amory O., 2244 So. Sheridan Rd., Highland Park, Ill.

C l Moore, Mrs. Amory O.

P a Morgan, John B., Montgomery Ave., Chestnut Hill.

p a Morgan, Mrs. John B., Montgomery Ave., Chestnut Hill.

P a Morgan, Randal, N. W. cor. Broad and Arch Sts.

P l Morrell, Mrs. Edward deV., Torresdale.

P L Morris, Effingham B., Girard Trust Co.

C L Morris, Effingham B.

P L Morris, Miss Lydia T., 826 Pine St.

P L Morris, William H., Thirtieth and Locust Sts.

P L Moss, Frank H., 518 Walnut St.

P l Moss, Mrs. Frank H., Bala, Pa.

C l McAllister, Miss Eliza Y., 3503 Baring St.

P L McAllister, James W., 1603 Green St.

P A McClees, J. E., 1507 Walnut St.

P L McFadden, George H., Eighteenth and Spruce Sts.

c a McFadden, George $\mathrm{H}$.

C a McFadden, J. Franklin, 115 Chestnut St.

P L McFadden, John H., N. E. cor. Nineteenth and Walnut Sts.

P L McIlhenny, John D., Lincoln Drive and Johnson St., Germantown.

C L McIlhenny, John D.

P a McKean, Thomas, Rosemont, $\mathrm{Pa}$.

c a McKean, Thomas.

P a McLean, William L., 207 Bulletin Bldg.

P L McNeely, Richard P., Bryn Mawr, Pa.

P l McNeely, Robert K., Merion, Pa.

P L McOwen, Frederick, 5871 Drexel Road, Overbrook.

P a Newbold's, William H., Son \& Co., 511 Chestnut St.

c a Newbold's, William H., Son \& Co.

P a Newhall, George M., 1209 Walnut St.

P a Newhall, Mrs. George M., 1209 Walnut St. 
P l Newman, John S., Hotel Majestic.

P a Nice, Eugene E., 1720 Diamond St.

P l Norris, Charles, 617 Walnut St.

P a Norris, Hon. George W., 1812 R St., N. W., Washington, D. C.

P l O'Neill, William C., 328 Walnut St.

P a Palmer, John T., Fifth and Locust Sts.

P l Pardee, Calvin, 239 W. Walnut Lane, Germantown.

P a Patterson, T. H. Hoge, 4231 Walnut St.

c a Patterson, T. H. Hoge.

P A Paxson, J. W., Co., 1021 N. Delaware Ave.

P a Peirce, Harold, 222 Drexel Bldg.

c a Peirce, Harold.

P l Perot, Effingham., $125 \mathrm{~S}$. Fifth St.

P l Perot, T. Morris, Jr., 917 Clinton St.

P L Peterson, C. Lehman, 7319 Bryan St., Mt. Airy.

P a Philadelphia Turngemeinde, Broad St. and Columbia Ave.

P a Plumly, George W., Co., 213 N. Fourth St.

P a Potter, Charles A., Chestnut Hill.

P a Potter, Hon. William, 1011 Chestnut St.

P l Powers, Thomas Harris, 1607 Walnut St.

C l Powers, Thomas Harris.

P l Price, Eli Kirk, 709 Walnut St.

P a Ralston, Robert W., N. E. cor. Thirteenth St. and Girard Ave.

P a Rau, William H., 238 S. Camac St.

P a Rea, Samuel, Broad Street Station.

P l Read, Mrs. Frank, 4105 Pine St.

C L Read, Mrs. Frank.

P a Register, Henry C., M.D., Haverford, Pa.

P l Rice, Mrs. Alexander H., Ashbourne, Pa.

P a Richardson, Thomas de Q., $439 \mathrm{~N}$. Twelfth St.

P a Riehlé, Frederick A., 1424 N. Ninth St.

C a Riehlé, Frederick A.

P a Ritchie, Mrs. Craig D., 414 N. Thirty-fourth St.

c a Ritchie, Mrs. Craig D.

P l Roberts, Mrs. Charles, 1327 Spruce St.

P a Roberts, Edward, 3rd, 406 Lafayette Bldg.

c a Roberts, Mrs. Emily L., Malvern, Pa.

P l Roberts, Miss Frances A., 1830 S. Rittenhouse Sq.

P a Roberts, G. Theodore, 1 Lexington Ave., New York.

c a Roberts, G. Theodore.

P L Robinson, Anthony W., 409 Chestnut St.

C L Robinson, Anthony W.

C L Robinson, Mrs. Anthony W., 409 Chestnut St.

P L Rogers, Roland C., South Brownsville, $\mathrm{Pa}$.

P a Rohner, Henry, 201 N. Fifth St.

P L Rolin, Harry M.

P a Rosengarten, Miss Fannie, 1704 Walnut St.

C a Rosengarten, Miss Fannie.

P a Rosengarten, Joseph G., 1704 Walnut St.

c a Rosengarten, Joseph G.

P L Rumpr, W. A., S. W. cor. Fifth and Cherry Sts.

* Deceased. 


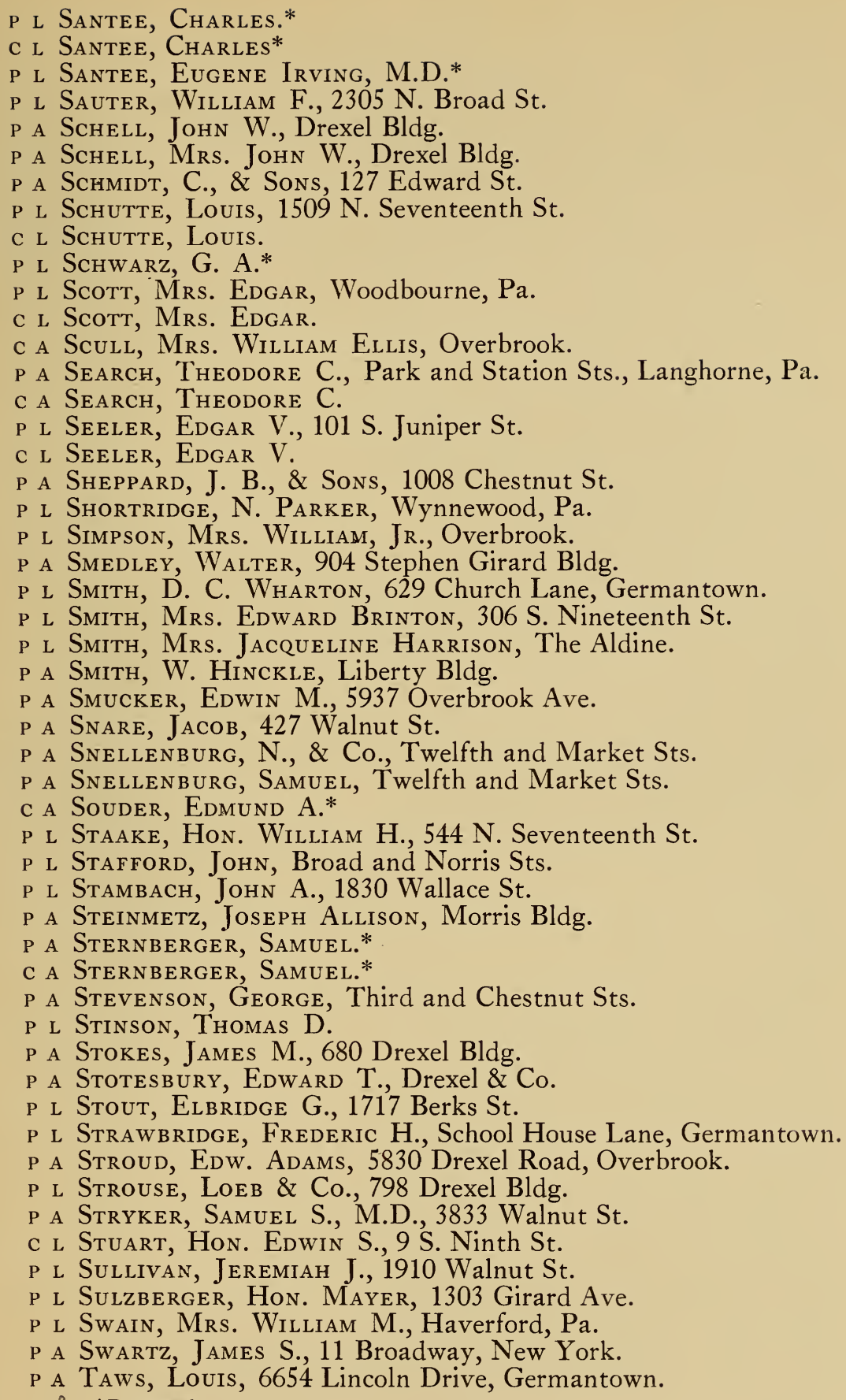


C a Taylor, Roland L., Morris Bldg.

P l Teller, Miss Louise S., 1727 Spring Garden St.

c a Tetlow, Mrs. Clara, 3619 Baring St.

P a Thomas, James B., Burd Bldg., Ninth and Chestnut Sts.

p a Thompson, Dr. Robert Ellis, Central High School.

P A Thomson, John L., 1060 Drexel Bldg.

P a Thomson, William, 64 N. Second St.

C L Thorn, Miss Mary.

p L Thropp, Mrs. Joseph E., 1701 Twentieth St., N. W., Washington, D. C.

p a Todd, Hon. M. Hampton, 2115 Spruce St.

P a Trask, John E. D.

P a Trueman, Dr. William H., 47 High St., Germantown.

P a Tryon, Edward K., Co., 10 N. Sixth St.

P l Turner, Mrs. Charles P., 1506 Walnut St.

P A Tyler, Sidney F., 1234 Land Title Bldg.

P l Van Rensselaer, Col. Alexander, 1801 Walnut St.

P a Vauclain, Samuel M., 500 N. Broad St.

P a von Moschzisker, Hon. Robert, City Hall

P L Wainwright, Joseph R.*

C L Wainwright, Joseph R.*

P a Wanamaker, Hon. John, 1301 Chestnut St.

P A Warden, William G., 1012 Witherspoon Bldg.

P l Waterall, William, 4714 Springfield Ave.

P a Weatherly, Mrs. L. Howard, 3919 Chestnut St.

P A Weaver, Hon. John, 1416 S. Penn Square.

P l Weber, Frederick.*

p l Weber, William E., 509 S. Tenth St.

p a Webster, George S., 4900 Penn St., Frankford.

P A Weimer, Albert B., The Aldine.

P A Wells, George B., 1101 Market St.

p l Wetherill, William Henry, 3734 Walnut St.

P a Wheeler, Mrs. Charles, Bryn Mawr, Pa.

C A Wheeler, Mrs. Charles.

P a White, J. Clarence, 5528 Wayne Ave., Germantown.

P L Widener, Joseph E., Land Title Bldg.

C l Widener, Joseph E.

P L Wiedersheim, Col. John A., 4408 Pine St.

P a Wiedersheim, Major William A.*

p a Wilbur, H. O., 237 N. Third St.

P L Williams, David E., Bala, Pa.

P a Williams, Edward P., 500 N. Broad St.

P A Williams, Ellis D., 560 Drexel Bldg.

P l Wilson, Capt. J. Lapsley, Overbrook, Pa.

P L Windrim, James H.*

C A Windrim, James H.*

P A Windrim, John T., Commonwealth Trust Bldg.

C A Windrim, John T.

P A Wister, Mrs. Jones, 1819 Walnut St.

P L Wolf, Mrs. Abraham S., 1530 Green St.

C l Wolf, Mrs. Abraham S.

p a Wolf, Hon. Clarence, Empire Bldg., Thirteenth and Walnut Sts. * Deceased. 
P L Wood, Walter, 1620 Locust St.

P L Wood, William, Wayne, Pa.

P L Wright, W. D. Craig, 2023 Walnut St.

c a Zantzinger, C. C., $112 \mathrm{~S}$. Sixteenth St.

c a Zantzinger, Mrs. C. C., 112 S. Sixteenth St.

P l Ziegler, George J., Jr., 1534 N. Sixteenth St.

P l Ziegler, Henry Z., 110 N. Thirty-fourth St. 


\section{ASSOCIATE MEMBERS}

Associate members pay one dollar annually in either Branch and two dollars for both.

$P$ indicates $P A R K$ branch.

$C$ indicates CITY branch.

* indicates DECEASED.

P Aersten, Mrs. Guilliaem, Jr., 1523 Walnut St.

C Aertsen, Mrs. Guilliaem, Jr.

P Bradford, Mrs. T. H., 1802 De Lancey Pl.

C Bradford, Mrs. T. H.

P Brubaker, Dr. Albert P., 3426 Powelton Ave.

P Delbert, Simon, Jr., Media, Pa.

p Doran, Mrs. Emma C., 1851 N. Nineteenth St.

c Doran, Mrs. Emma C.

p Gaskill, J. Howard, M.D., 1627 Walnut St.

c Gaskill, J. Howard, M.D.

p Godwin, Joseph B., 203 Walnut Pl.

P Hamilton, Mrs. Wilbur F., 327 Llandrillo Road, Cynwyd, Pa.

p Howell, Cooper, 1523 Walnut St.

C Howell, CoOper

P Keller, Prof. Harry F., 2313 Green St.

P Kessler, John, 1520 N. Twenty-fourth St.

P Küsel, Dr. George C., 235 S. Fifteenth St.

P Küsel Dr. Mary H. Stilwell, 235 S. Fifteenth St.

P Laird, Prof. Warren P., University of Pennsylvania.

P McMichael, Hon. Charles B., 2039 De Lancey Pl.

P Montgomery, Mrs. J. H., 1602 W. Erie Ave.

c Montgomery, Mrs. J. H.

P Paul, J. Rodman, 903 Pine St.

P Peters, Richard, 1101 Spruce St.

P Rich, Mrs. Sarah M. S., 1820 De Lancey Pl.

p Rowland, Mrs. William O., Jr., Torresdale.

c Rowland, Mrs. William O., Jr.

p Rulon, Mrs. J. W. K., 2115 De Lancey Pl.

P Thomas, James B., Jr., Burd Bldg., Ninth and Chestnut Sts.

P Thomas, Mrs. Lizzie G., Burd Bldg., Ninth and Chestnut Sts.

P Warren, Henry Mather.*

p Warren, Mrs. Henry Mather, Devon, Pa.

p Warren, Richard F., Devon, Pa.

P Wolf, Louis, Twelfth and Callowhill Sts.

c a Thomson, William.

P A Thorn, Miss Mary, 1527 N. Sixteenth St.

*Deceased. 


\section{N D E X}

Adams, Herbert. . . . . . . . . . . . . . . . . . . . . . . . . . . . . 187

Annual Addresses . . . . . . . . . . . . . . . . . . . . . . . . . . . . . . . . 253-260

Art Museum................................ 30

Baldwin, Matthias W. . . . . . . . . . . . . . . . . . . 178

Barye, Antoine Louis . . . . . . . . . . . . . . . . . . . . . . . . 189

Beaver, Gen. James A. . . . . . . . . . . . . . . . . . . . . . 163

Beck, Hon. James Montgomery, LL.D., Litt.D., address. . . . . . . . 11

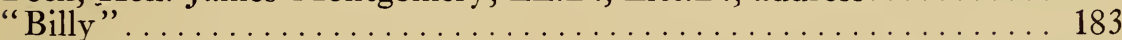

Biographies of Founders. . . . . . . . . . . . . . . . . . . . . .79-128

Bissell, Frederick Meade . . . . . . . . . . . . . . . . . . 83

Bissell, George Edwin. . . . . . . . . . . . . . . . . . . . . . . 191

Boyle, John J. ................................. 193

Cain, Auguste . . . . . . . . . . . . . . . . . . . . . . . . . . . . . . 195

Calder, Alexander Milne . . . . . . . . . . . . . . . . . . . . . 197

Calder, A. Sterling ..... . . . . . . . . . . . . . . . . . . . . 199

Campbell, Archibald ........................... 85

Cannon, Spanish . . . . . . . . . . . . . . . . . . . . . . . 150-151

Carpenters' Hall ................................... 179

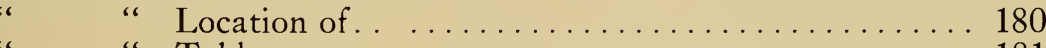

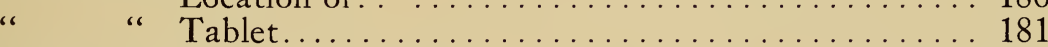

Celebration of Fiftieth Anniversary................... 10

Claghorn, James L . . . . . . . . . . . . . . . . . . . . . . . . . 87

Cohen, Charles J............................... $77 \& 185$

Cohen, Katherine M............................... 201

Committees......................................6\& 8

Constitution, Preamble to .......................... 262

Converse, John H. . . . . . . . . . . . . . . . . . . . . . . . . . 115

Cowboy............................................ 169

Cox, John Bellangee............................ 91

Crawford, Andrew Wright......................... 244

Crawford, Maj.-Gen. S. W.......................... 161

Curtin, Governor............................ 162

Dahlgren, Admiral............................... 159

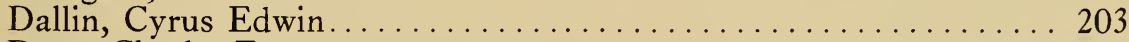

Dana, Charles E. . . . . . . . . . . . . . . . . . . . . . . 119

Danaid.............................................. 171

Diana Borghese.................................... 135

Dickens and Little Nell . . . . . . . . . . . . . . . . . . . . . . . . . 177

Dolan, Thomas. .................................... 93

Doves, Feeding the .............................. 171

Drexel, Anthony J................................. 95

Duck Girl...................................... 182

Dying Lioness . . . . . . . . . . . . . . . . . . . . . . . . 136 


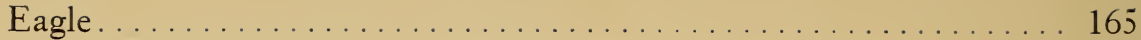

Elwell, Frank Edwin. . . . . . . . . . . . . . . . . . . . . 205

Ezekiel, Sir Moses. . . . . . . . . . . . . . . . . . . . . . . . . 208

Fairmount Parkway .........................4 \& 243

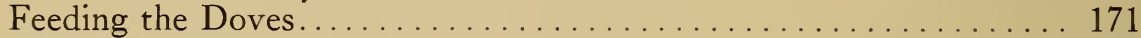

Florentine Lions. . . . . . . . . . . . . . . . . . . . . . . . . . . . . . . . . . 142

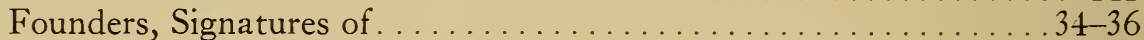

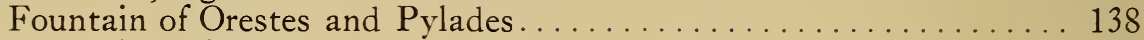

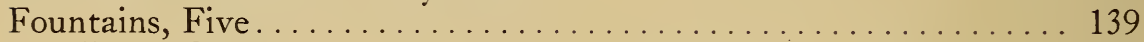

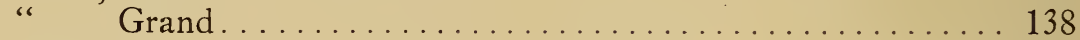

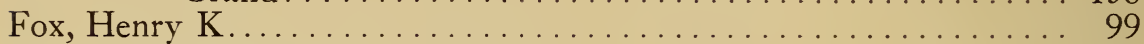

Frémiet, Emmanuel . . . . . . . . . . . . . . . . . . . . . 211

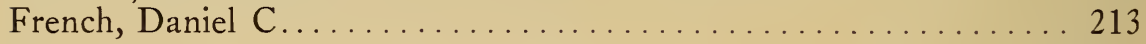

Garfield, Hon. James A. . . . . . . . . . . . . . . . . . . . . . 148

Gibson, Henry C . . . . . . . . . . . . . . . . . . . . . . . . . . 101

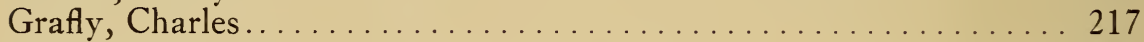

Grant, Gen. U. S. . . . . . . . . . . . . . . . . . . . . . . . . . 149

Gest, John B. . . . . . . . . . . . . . . . . . . . . . . 164

Hancock, Maj.-Gen. Winfield Scott..................... 155

History of the Fairmount Parkway................... 244-252

History of the Fairmount Park Art Association . . . . . . . . . . . 31-73

Horstmann, William J . . . . . . . . . . . . . . . . . . . . . 103

Howell, Col. Charles H. . . . . . . . . . . . . . . . . . . . . . . . 79

Hudson Bay Wolves............................. 134

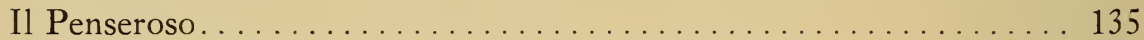

Illustrations of Founders . . . . . . . . . . . . . . . . . . . . . . . . .

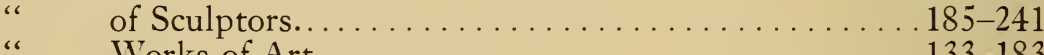

" Works of Art. . . . . . . . . . . . . . . . . 133-183

Japanese Temple Gate. . . . . . . . . . . . . . . . . . . . . . . 168

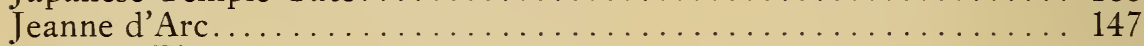

Jonsson, Einar. . . . . . . . . . . . . . . . . . . . . 219

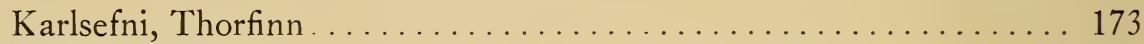

Kemeys, Edward ........................... 221

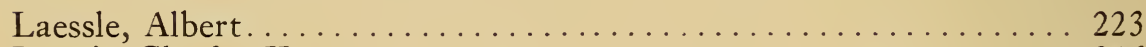

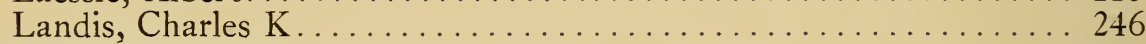

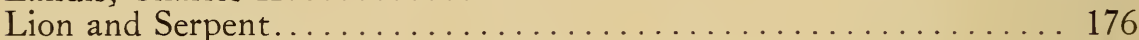

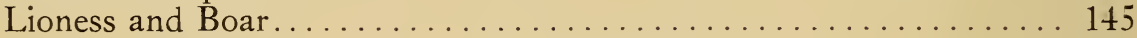

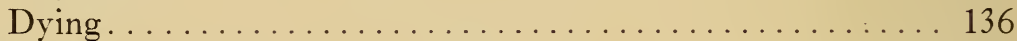

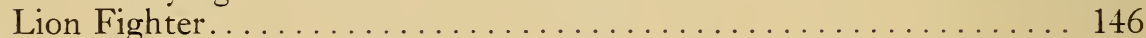

Lions, Florentine. . . . . . . . . . . . . . . . . . . . . . . . . 142

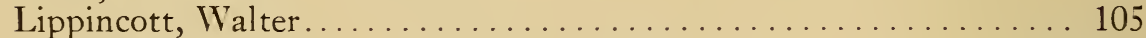

List of Works of Art. . . . . . . . . . . . . . . . . . . . . . 129-131

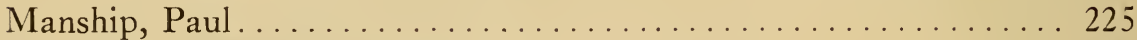

McClellan, Maj.-Gen.............................. 156

Meade, Maj.-Gen. George Gordon........................ 143

Medicine Man .................................... 166 
Members

Membership, Classes of

Miller, Leslie W., LL.D

Monumental Memorial

Morris, John T.

Murray, Samuel ...

Ogden, H. Corbit

Officers, Present.

Parkway, Fairmount

Penguins

Perrine, William

Porter, Admiral.

Potter, Edward C

Preamble to Constitution

Remington, Frederic 231

Rhind, J. Massey .

Rush, William

Saint Gaudens, Augustus

Samuel, Ellen Phillips.

Schwarzmann, Joseph Hermann

Signatures of Founders.

Silenus and Bacchus.

Smith, Joseph Frailey

Smith Memorial.

Smith, Richard

Spanish Cannon.

Stone Age.

Sun-dial.

Tam O'Shanter. . . . . . . . . . . . . . . . . . . . . . . . . . . . . . 137

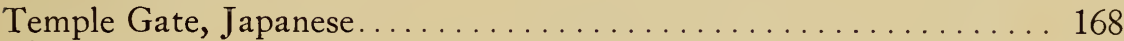

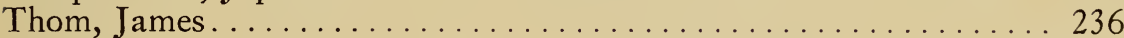

Treasurer's Account. . . . . . . . . . . . . . . . . . . . . . . . . . . . . . 261

Trotter, Edward H. . . . . . . . . . . . . . . . . . . . . . . . 111

Trustees, Present............................. 7

Since Organization....................... 75

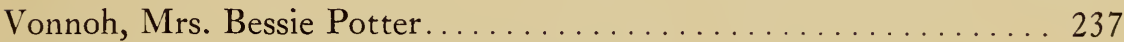

Ward, John Q. A................................. 239

Waterworks, Portico of ......................... 12-28

Webster, George S................................ 244

White, Samuel S . . . . . . . . . . . . . . . . . . . . . . . . 113

Windrim, James H. . . . . . . . . . . . . . . . . . . . . . . . . . 160

Walff, Albert William ............................. 241

Works of Art, List of. . . . . . . . . . . . . . . . . . . . 129-131

“ Illustrations . . . . . . . . . . . . . . . . . .133-183

IVrestlers.................................. 141 


